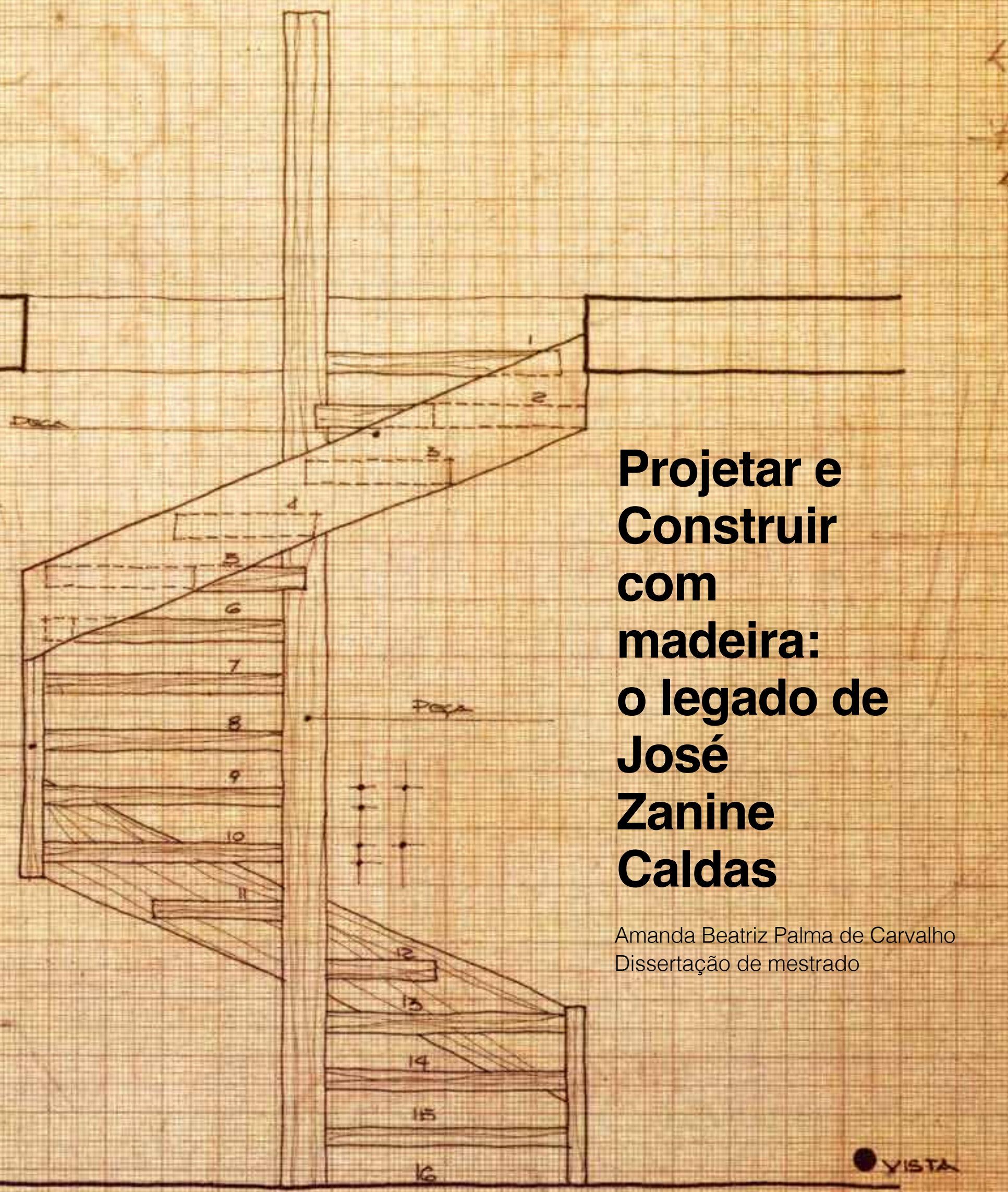



Amanda Beatriz Palma de Carvalho

\section{Projetar e Construir com madeira: o legado de José Zanine Caldas}

Dissertação apresentada à Faculdade de Arquitetura e

Urbanismo da Universidade de São Paulo, como requisito parcial para obtenção do grau de Mestre em

Ciências, pelo programa de Arquitetura e Urbanismo.

Exemplar revisado e alterado em relação à versão original, sob responsabilidade da autora e anuência da orientadora.

A versão original, em formato digital, ficará arquivada na Biblioteca da Faculdade. São Paulo, 21 de maio de 2018.

Área de concentração: Design e Arquitetura

Orientadora: Prof.a Titular Dra. Maria Cecília Loschiavo dos Santos 
Autorizo a reprodução e divulgação total ou parcial deste trabalho, por qualquer meio convencional ou eletrônico, para fins de estudo e pesquisa, desde que citada a fonte.
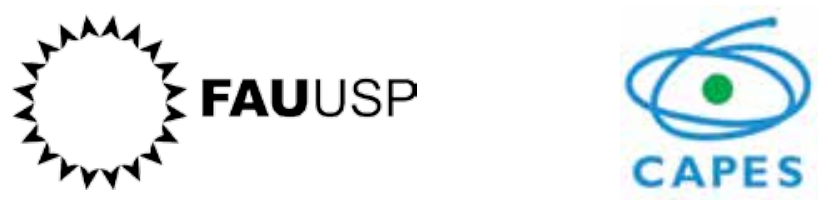

Catalogação na Publicação

Serviço Técnico de Biblioteca

Faculdade de Arquitetura e Urbanismo da Universidade de São Paulo

Carvalho, Amanda Beatriz Palma de

Projetar e construir com madeira: O Legado de José Zanine Caldas /

Amanda Beatriz Palma de Carvalho; orientadora Maria Cecília

Loschiavo dos Santos — São Paulo, 2018_194 p.

Dissertação (Mestrado) - Faculdade de Arquitetura e Urbanismo da

Universidade de São Paulo. Área de concentração: Design e Arquitetura

1. Design. 2. Arquitetura. 3. Madeira. 4. Ensino. 5. Construção.

6. Saber Tradicional I. Loschiavo, Maria Cecília Loschiavo dos, orient.

II. Título.

Elaborada eletronicamente através do formulário disponível em: < http://www.fau.usp.br/ fichacatalografica/> 




\section{Agradecimentos}

Foram muitas as pessoas e instituições que me ajudaram no percurso de dois anos de desenvolvimento do trabalho do mestrado.

Inicialmente, agradecerei às instituições que me auxiliaram: ao programa de pós-graduação em Arquitetura e Urbanismo da Faculdade de Arquitetura e Urbanismo da Universidade de São Paulo (FAU-USP), à Capes, pelo apoio financeiro, aos funcionários da pós-graduação, do Laboratório de Modelos Experimentais (LAME), biblioteca e do vídeo FAU pela ajuda sempre que necessária.

Agradeço à Maria Cecília Loschiavo dos Santos, que me concedeu a alegria de ser sua orientanda, e que desde a graduação acreditou no potencial dos estudantes, incentivando-os na busca de conhecimento, no desvelar dos questionamentos próprios de cada um, sempre de forma muito generosa.

Ao professor Ivan do Valle, por compartilhar comigo documentos, além de seu conhecimento, ajudando-me na descoberta do trabalho de Zanine em Nova Viçosa.

À professora Tatiana Sakurai, pelas longas conversas carinhosas e cheias de referências que serviram de suporte para o trabalho.

Ao Rafael Murolo, pela paciência e amor na convivência diária, pela ajuda nos desenhos e pelas referências de trabalho que pudessem acalmar o desespero dos dias em que eu não sabia o que fazer, bem como por sempre me incentivar, mesmo sabendo que minhas escolhas me fariam mergulhar em períodos de intenso trabalho.

À minha família e amigos, por entenderem e apoiarem o momento tão introspectivo que é a escrita de uma dissertação.

A pesquisa de campo na Bahia não seria possível sem a colaboração de Teodório Cardoso, de Cida e Carlos Fanticelli, moradores de Nova Viçosa que gentilmente abriram as portas de suas casas, deram informações e ainda percorreram comigo a cidade, mostrando as residências feitas por Zanine, contando a história da cidade e me apresentando o Peu, seu Tancredo, Benedito e Reinaldo, carpinteiros que me contaram como era a oficina de Zanine e me ensinaram como trabalhavam.

Ao Zanininho e Cuca, que gentilmente conversaram comigo, mostrando o seu acervo fotográfico e me contando um pouco da história do seu pai. 
A Reduzino, por toda informação sobre o trabalho de Zanine, por me mostrar belas casas na Joatinga e em Niteroy.

A todos os entrevistados, Ricardo Caruana, Hélio Olga, Cydno Silveira, Elayne Farias, Claudia Orthof, Ustane Lopes, Júlio Katinsky, que me receberam carinhosamente, concedendo importantes informações para o desenvolvimento do trabalho.

A Luiz Otávio Chaves, pelo vídeo gentilmente enviado, mostrando o trabalho que Zanine desenvolveu enquanto trabalhou no Centro de Desenvolvimento das Aplicações das Madeiras do Brasil (DAM).

A Rafael Padial pela revisão do trabalho e por estar sempre ao meu lado.

À Ligia Carvalho, por ler e reler meu trabalho, ajudando com metodologia e puxando minha orelha sempre que necessário.

À Rafaela Netto, pelas belas fotografias e pelo bom humor mesmo num sábado de manhã, a Diego Arvate, pela edição dos vídeos.

Às queridas Ana e Alice Viggiani, que mesmo gripadas me receberam e me ensinaram a fechar o arquivo final do trabalho para impressão.

À Kátia Gondo, querida amiga que passou a sua infância em Nova Viçosa, pelas gostosas conversas sobre a cidade. 


\section{Sumário}

11 Resumo

11 Abstract

13 Introdução

15 Apresentação do trabalho

16 Estrutura do texto

17 Metodologia

19 Documentos

23 Deslocamento no território

24 A importância do tema

25 Objetivos

27 Capítulo 1: Zanine e o Saber Fazer

29 Zanine e o Saber fazer

32 Belmonte

38 Rio de Janeiro e São Paulo na década de 1940

45 São José dos Campos e São Paulo na década de 1950

55 Primeira ida a Brasília

62 Casas da Joatinga

70 Segunda ida a Brasília

73 Capítulo 2: Nova Viçosa

76 História de Nova Viçosa

87 Projeto urbanístico

95 Obras na cidade

95 Casa dos triângulos

95 Ateliê de Krajcberg (casa de pirâmide)

98 Fazenda Campo Grande

$98 \quad$ Casa de Suzana Rodrigues

101 Casa de Zanine no Rio Peruípe

$101 \quad$ Casa demolida

101 Oficina de Zanine

112 Móveis-Denúncia

119 Casas pré-elaboradas

133 Capítulo 3: a residência no Morumbi

152 Programa da residência

175 Diálogo com técnicas construtivas tradicionais

181 Considerações finais

189 Bibliografia 



\section{Resumo}

Esta dissertação estuda a obra de José Zanine Caldas, relacionando a sua trajetória de vida com o saber-fazer tradicional, com enfoque na época em que morou e trabalhou em Nova Viçosa, sul da Bahia, cidade para a qual fez um projeto urbanístico. Nela também teve uma oficina, onde desenvolvia casas chamadas de "pré-elaboradas", pois eram fabricadas na Bahia, montadas, desmontadas e enviadas para todo o Brasil, para serem remontadas em seu terreno definitivo. Na mesma cidade, projetou móveis que chamou de "móveis-denúncia".

Este trabalho também estuda o saber-fazer de Zanine, descrevendo, portando, produção de móveis e casas, desde o corte da madeira. No caso das residências, também descreve a montagem no seu local definitivo. Para isso, fez-se a análise de uma casa "préelaborada" localizada no bairro do Morumbi, São Paulo.

Palavras-chaves: arquitetura, design, construção, ensino, madeira, saber tradicional.

\section{Abstract}

Studies the work of José Zanine Caldas, relating his life trajectory with the traditional know-how, focusing on the time when he lived and worked in Nova Viçosa, south of Bahia, city for which he made an urban project and where he also had a manufactory, where he developed houses called "pré-elaboradas" (pre-elaborated). These houses were manufactured in Bahia, assembled, dismantled and sent all over Brazil to be reassembled in their definitive location. During the same period of time he also designed pieces of furniture called "móveis-denuncia" (furniture complaint).

This research also studies the know-how of Zanine, describing the production of these pieces of furniture and houses since the cutting of the wood. In the case of residences, it describes the assembly at its final location. For this purpose, we analised one "pre-elaborated" house, located in the district of Morumbi, São Paulo.

Keywords: architecture, design, construction, education, wood, traditional knowledge. 

introdução 



\section{apresentação do trabalho}

O trabalho aqui apresentado estuda o arquiteto-designer ${ }^{1}$ José Zanine Caldas e sua relação com o saber-fazer, com ênfase no período em que trabalhou em Nova Viçosa, BA. Utiliza-se o termo saber-fazer inspirado na apresentação que a professora Maria Cecília Loschiavo dos Santos faz do Zanine:

(...) ele sempre foi o artífice, o fazedor, em oposição a outros artistas, designers, arquitetos seus contemporaneos. Ele é verdadeiramente uma figura dupla: o designer - artesão ou o arquiteto maquetista, que tem a experiência do saber-fazer, do trabalho da mão associado às ferramentas, ao traço, ao desenho. Este é um ponto fundamental em que se baseia toda a sua produção. Para ele este saber-fazer, este artesanato nunca esteve divorciado do projeto, ao contrário de muitos arquitetos de sua geração. (SANTOS, 1993, p. 158)

Para isso, buscou-se relacionar a trajetória da vida do Zanine com as culturas dos lugares onde esteve e com as pessoas com as quais conviveu, a fim de entender esse saber-fazer.

1. Apesar de Zanine nunca ter frequentado uma Faculdade, decidiu-se designá-lo neste trabalho de arquiteto-designer, pois sua obra em ambas as áreas apresenta qualidades construtivas, formais e tecnológicas. Considera-se que ele aprendeu arquitetura e design na prática, ao executar maquetes para os principais arquitetos do modernismo brasileiro e discutindo as soluções projetuais com os mesmos. Além disso, Zanine recebeu das mãos de Lúcio Costa o título de Arquiteto Honorário, atribuído pelo LAB. 


\section{estrutura}

\section{do texto}

O trabalho é subdividido em 3 capítulos. O primeiro capítulo relaciona a trajetória de vida de José Zanine Caldas e o seu saber-fazer. Para isso foi feita uma pesquisa bibliográfica, com o intuito de entender a figura multifacetada que foi Zanine, maquetista, designer, artesão, arquiteto, paisagista e professor, além de entender os deslocamentos geográficos feitos por ele na busca de trabalho ou matéria-prima.

O segundo capítulo disserta sobre o momento em que Zanine esteve em Nova Viçosa. Estudou-se a relação de trabalho com os habitantes do local, habilidosos construtores de canoa, e como Zanine partiu das técnicas construtivas e da matéria-prima do local para produzir móveis únicos, chamados de móveis-denúncia, e estruturas de casas que Zanine chamou de pré-elaboradas. Eram estruturas de madeira produzidas na sua fábrica em Nova Viçosa e enviadas para todo o Brasil. Esse capítulo também mostra casas feitas pelo arquiteto-designer na cidade, além do projeto urbanístico desenvolvido por ele para lá.

O terceiro capítulo realiza uma análise meticulosa de uma casa feita em Nova Viçosa, na fábrica de Zanine, e enviada para o bairro Morumbi, em São Paulo, relacionando-a a técnicas tradicionais de construção em fazendas do sul de Minas Gerais e a casas de enxaimel, encontradas no sul do país e em Petrópolis, RJ. 


\section{metodologia}

O trabalho é de natureza qualitativa, que permite uma combinação de técnicas de coleta e instrumentos de análise de dados para atender ao objetivo delimitado. De acordo com Neves (1996, p. 1), a pesquisa qualitativa "não emprega instrumental estatístico para análise; seu foco de interesse é amplo e parte de uma perspectiva diferenciada da adotada pelos métodos quantitativos”.

Quanto aos objetivos, a pesquisa descritiva mostrou-se a mais adequada, pois se pretende recriar processos de produção utilizados por Zanine, descrevendo-os em detalhes. Para Gil (1991), usa-se esse tipo de pesquisa quando a finalidade é descrever as características de determinado fenômeno ou estabelecer relações entre variáveis. Ela possibilita identificar fenômenos, os fatos são observados, registrados, analisados, classificados sem que o pesquisador interfira neles. Os fenômenos são estudados, mas não manipulados. É um tipo de estudo adequado quando se necessita obter melhor entendimento a respeito do comportamento de vários fatores e elementos que influem sobre determinados fenômenos.

Os instrumentos de coleta de dados utilizados foram o bibliográfico, a observação e a entrevista. A pesquisa bibliográfica foi elaborada a partir de material já publicado, constituído principalmente de livros, artigos de periódicos e, atualmente, material disponibilizado na internet (MANHÃES, MEDEIROS, KAUARK, 2010, p. 28). A entrevista é um "processo de interação social entre duas pessoas na qual uma delas, o entrevistador, tem por objetivo a obtenção de informações por parte do outro, o entrevistado" (HAGUETTE, 1997, p. 86), sendo usada para obter relatos sobre fatos dos quais não existem registros escritos, assim como conhecer suas opiniões, percepções e valores. A observação, por sua vez, leva à descoberta de aspectos da realidade por promover a aproximação entre o investigador e o objeto de estudo, momento em que ele usa todos os sentidos para sentir, "ver, ouvir e examinar os fatos, os fenômenos que pretende investigar" (GERHARDT, SILVEIRA, 2009, p. 74). Os dados foram registrados por escrito, por meio de fotografia, vídeo ou áudio, conforme melhor se aplicar a cada situação.

Este trabalho se direciona segundo duas linhas mestras: a primeira se apresenta como uma cronologia da vida de Zanine, vinculando-a ao seu saber-fazer, onde se 
pretende identificar culturas, técnicas construtivas e matéria-prima que influenciaram o seu trabalho e foram utilizadas por ele em cada momento da sua vida. A montagem dessa cronologia implicou um levantamento bibliográfico e iconográfico em revistas, documentários, livros, teses, catálogos de exposição e arquivos particulares de fotografias.

A segunda linha se desenvolve a partir de pesquisas de campo, com o intuito de reconstruir as experiências de projeto do arquiteto-designer no período em que esteve em Nova Viçosa. Pelo pouco estudo existente sobre esse período, foi necessário entrevistar arquitetos, engenheiros e carpinteiros que trabalharam com Zanine, além de seus familiares e amigos. Além disso, foram registradas através de fotografias algumas obras de Zanine que ainda existem na cidade de Nova Viçosa. Após isso feito, produziu-se desenhos reconstituindo como era a fábrica de Zanine em Nova Viçosa. O mesmo foi feito a partir de resquícios da mesma, que puderam ser observados durante visita de campo e dos depoimentos cedidos à pesquisadora. Outros desenhos foram feitos a fim de explicar o método de trabalho de Zanine, demonstrando desde como a madeira chegava à sua oficina, até a sua transformação em móvel ou residência.

Foi feita vasta pesquisa bibliográfica e iconográfica em fontes primárias e secundárias e entrevistas a profissionais que trabalharam com Zanine e a familiares e amigos, que também forneceram imagens para a pesquisa. Também foram produzidos imagens e filmes a partir de visitas a residências projetadas por Zanine e a lugares onde ele trabalhou. 


\section{documentos}

Os principais dentre os diversos livros estudados para escrita do primeiro capítulo são os trabalhos de mestrado e doutorado da prof.a Titular Dra. Maria Cecília Loschiavo dos Santos, Móvel Moderno no Brasil, e Tradição e Modernidade no Móvel Brasileiro; a dissertação de mestrado de Alexandre Penedo Barbosa de Melo, Moveis artísticos Z (1948-1961): o moderno autodidata e seus ressortes sinuosos; o livro de Suely Ferreira da Silva, Zanine sentir e fazer, a dissertação de mestrado da Giselle Marie Cormier Chaim, O mestre, a madeira e a habitação: Residências de Zanine Caldas em Brasilia 1963-1985; e o trabalho de iniciação científica da Clara Batholomeu, José Zanine Caldas e a sua contribuição ao ensino de arquitetura e design. A combinação desses teóricos é que possibilitou a análise da trajetória da vida de Zanine.

Para a escrita do segundo capítulo, usamos livros sobre a história de Nova Viçosa. Entre eles, o da advogada e moradora de Nova Viçosa Jean Albuquerque, Retrato Histórico de Nova Viçosa - Babia, o livro do biólogo Príncipe Maximiliano de WiedNeuwied, Viagem ao Brasil nos anos de 1815 a 1817; e o do ex-prefeito de Nova Viçosa, Teodório Cardoso, Nova Viçosa, Bahia: História do Nascimento, vida e progresso da cidade das mais belas praias. Também foram estudados livros de Paulo freire, Pedagogia da Autonomia: saberes necessários à prática educativa e Pedagogia do oprimido.

Para o terceiro capítulo foram estudados livros de teorias construtivas tradicionais brasileiras. Para isso, leu-se o trabalho de mestrado de Cícero Ferraz Cruz, Fazendas do Sul de Minas Gerais: arquitetura rural nos séculos XVIII e XIX, o livro Engenho e Tecnologia, de Ruy Gama, além de livros que explicam a técnica do enxaimel usada em Santa Catarina, tendo como teórico principal o Prof. Günter Weimer, Arquitetura Enxaimel em Santa Catarina.

A pesquisa contou com imagens pertencentes a diversos arquivos pessoais, no Rio de Janeiro, em Nova Viçosa, em Brasília, em Joinville e em São Paulo. As principais fontes utilizadas foram o acervo documental da USP, no qual encontramos os processos de contrato de Zanine para trabalhar como técnico do LAME (assim como a sua rescisão de contrato); o arquivo pessoal do professor Ivan do Valle, no qual encontramos desenhos técnicos feitos por Zanine de detalhes-padrão para suas residências; o arquivo pessoal da filha de Zanine, Déa de Zanine (Cuca), com diversas fotografias de períodos distintos da vida do arquiteto-designer; o arquivo pessoal de 
Carlos Otto Fanticelli, com fotografias da fábrica de laminados Elecunha e da região de Nova Viçosa nos terceiro quarto do século XX; o arquivo pessoal do engenheiro Hélio Olga, com fotografias da montagem da casa pré-elaborada do bairro Morumbi, em São Paulo, além do seu projeto de arquitetura, feito pelo Zanine; o arquivo pessoal do arquiteto Cydno Silveira, com projetos desenvolvidos pelo mesmo sob orientação de Zanine, quando foi estudante da UnB; o arquivo pessoal de Elayne Farias, com diversas fotografias de construção de residências projetadas por Zanine; e o acervo pessoal de Claudia Orthof, com fotografias da época da construção de Brasilia e de seus pais, Sylvia Orthof e Dr. Sávio Pereira Lima. Também foi feita pesquisa no acervo municipal de Joinville, onde encontramos diversos livros sobre a técnica do enxaimel.

As visitas de campo foram fundamentais como verificação dos remanescentes das obras produzidas por Zanine. Dentre elas, destaca-se a viagem a Nova Viçosa, na qual foi possível verificar obras do arquiteto ainda existentes na cidade, assim como ruínas da sua fábrica. Também foram encontrados móveis desenhados e produzidos por Zanine no período, que se encontram em bom estado.

Ao total, temos aproximadamente 20 horas de gravação em áudio e em imagem. Essas entrevistas estão devidamente transcritas. Segue lista de entrevistados:

entrevistado

Ricardo Caruana

Ivan do Valle

Júlio Katinsky

Ivan do Valle e

Elayne Farias

\section{relação com a pesquisa}

Arquiteto, professor

da Escola da Cidade.

Trabalhou com Zanine em

Nova Viçosa e no Rio de Janeiro.

Arquiteto, professor da UnB, trabalhou com

Zanine nas décadas de 1980 e 1990.

Arquiteto, professor da FAU

Elayne é Arquiteta, trabalhou com Zanine nas décadas de 1980 e 1990.

\section{data e local da entrevista}

São Paulo, SP, 29 de fevereiro de 2016.

São Carlos, SP, 09 de junho de 2016.

São Paulo, SP, 27 de junho de 2016.

Brasília, DF, 27 de setembro de 2016. 
Ricardo Caruana

Helio Olga

Reduzino da Silva

Benedito Batista

Peu

Reinaldo da Silva

Teodório Cardoso

Carlos Fanticelli

Maria Aparecida Fanticelli (Cida)

Tancredo Barros descrição na página anterior.

Engenheiro que desenvolveu seus primeiros trabalhos com madeira junto a Zanine, montando casas pré-elaboradas em São Paulo.

Carpinteiro que trabalhou com Zanine a partir da década de 1960.

Carpinteiro que trabalhou com Zanine em Nova Viçosa na década de 1970.

Carpinteiro que trabalhou com Zanine em Nova Viçosa na década de 1970.

Pescador que trabalhou com Zanine em Nova Viçosa na década de 1970.

Trabalhou na oficina de Zanine de Nova Viçosa na década de 1970.

Industriário, seu pai trabalhava na Elecunha.

Professora de Nova Viçosa e uma das organizadoras dos eventos sobre Zanine na cidade.

Carpinteiro que trabalhou com Zanine em Nova Viçosa na década de 1970.
São Paulo, SP, 25 de novembro de 2016.

São Paulo, SP, 02 de fevereiro de 2017.

Rio de Janeiro, RJ, 04 de maio de 2017.

Nova Viçosa, BA, 17 de agosto de 2017.

Nova Viçosa, BA, 17 de agosto de 2017.

Nova Viçosa, BA, 17 de agosto de 2017.

Nova Viçosa, BA, 17 de agosto de 2017.

Nova Viçosa, BA, 19 de agosto de 2017.

Nova Viçosa, BA, 19 de agosto de 2017.

Nova Viçosa, BA, 19 de agosto de 2017. 
Teodório entrevista

Benedito

Casal Maria Fernanda

Magalhães e Joaquim Jubé

Claudia Orthof

Cydno Silveira

Déa de Zanine (Cuca)

Ustane Lopes

Carmem Gomes
Entrevista gravada por Laressa, neta de Teodório, a pedido da pesquisadora, na qual Benedito é entrevistado por Teodório. Entrevista usada para confecção de vídeo para a Bienal de arquitetura de 2017.

Casal que mora na casa pré-elaborada projetada pelo Zanine e localizada no bairro do Morumbi.

Médica e parteira, filha de Sylvia Orthof e Dr. Sávio, médico da Elecunha. Conviveu com Zanine durante a sua infância em Brasília, começo da década de 1960.

Arquiteto, amigo, estudante de Zanine e fotógrafo das suas obras. Trabalharam juntos desde 1960.

Filha de Zanine e Delza.

Cliente para a qual Zanine fez a sua última casa.

Prima do Zanine por parte de Mãe
Nova Viçosa, BA, 12 de setembro de 2017.

São Paulo, SP, 02 de novembro de 2017.

Teresópolis, RJ, 08 de novembro de 2017.
Rio de Janeiro, RJ, 09 de novembro de 2017.

Rio de Janeiro, RJ, 09 de novembro de 2017.

Niteroi, RJ, 09 de novembro de 2017.

Belmonte, BA, 09 de maio de 2018.

Também foram registradas imagens dos lugares visitados, com ênfase nas obras de Zanine e do seu saber-fazer. Essas imagens estão devidamente catalogadas, constituindo um banco importante para estudo da metodologia de projeto do designer arquiteto e da atuação profissional da pesquisadora. 


\section{deslocamentos \\ da pesquisadora \\ no território}

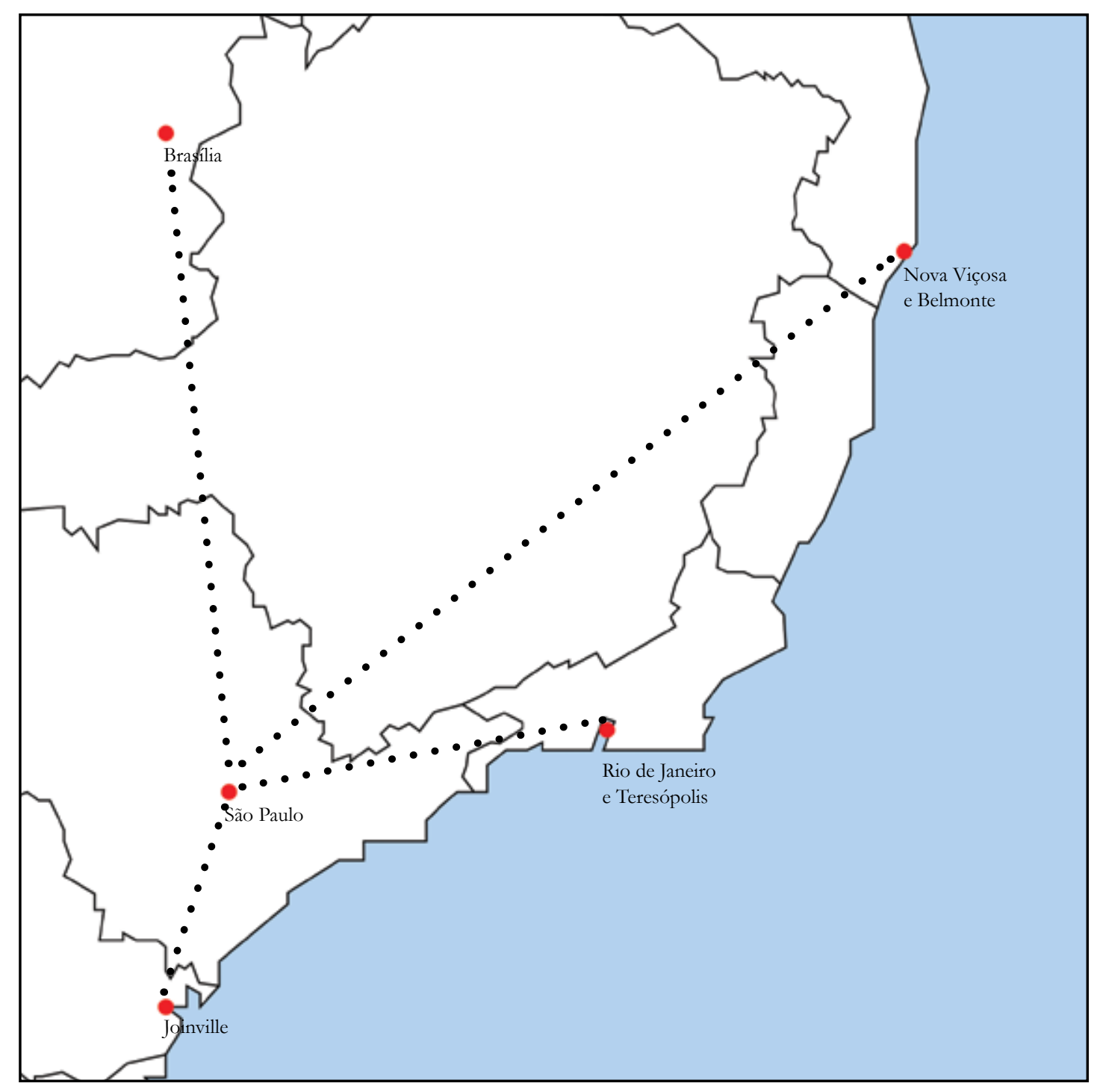




\section{a importância do tema}

É relevante a obra de José Zanine Caldas para as áreas de design, arquitetura, meio ambiente e educação no Brasil. No design, foi um dos pioneiros na utilização do compensado para a produção de mobília, permitindo que o móvel tivesse custo acessível somado a um bom desenho.

Figura ímpar e multifacetada, soube olhar para a arquitetura vernacular, vendo suas potencialidades e fazendo uma releitura da mesma, tornando-se internacionalmente reconhecido através do projeto de casas feitas com estrutura de madeira; influenciou os principais profissionais atuais da área de construção com madeira no Brasil, sejam eles arquitetos ou engenheiros.

Foi um importante maquetista, trabalhando junto aos principais arquitetos do país na segunda metade do século XX: Oscar Niemeyer, Professor Alcides da Rocha Miranda, Oswaldo Bratke, entre outros.

$\mathrm{Na} F A U$ foi técnico de maquetes, fundou o LAME, importante laboratório na formação de designers e arquitetos. Também fundou o laboratório de maquetes da $\mathrm{UnB}^{1}$. Além desses dois trabalhos em que exerceu funções de técnico e de professor, auxiliando estudantes na construção de maquetes e no desenvolvimento do pensamento tridimensional, pode-se afirmar que, informalmente, ensinou inúmeras pessoas sem formação escolar a construírem casas com estrutura de madeira. Muito comprometido com o uso racional dos materiais, foi um dos primeiros a denunciar a queima das florestas do nordeste.

Apesar de uma extensa obra de qualidade e de influenciar na produção de arquitetura e móveis em madeira no Brasil, há falta de estudos na área. Sendo assim, esta pesquisa procura preencher essa lacuna.

1. Após o encerramento da Fundação DAM na FAU UnB no início dos anos 1990, essas oficinas deram lugar ao Laboratório de Modelos Reduzidos (LMR), até hoje perpetuando as atividades de ensino e pesquisa sobre as construções estruturadas em madeira e na obra de José Zanine Caldas 


\section{objetivos e justificativas}

Com esta pesquisa pretendeu-se conhecer a obra de José Zanine Caldas, com ênfase no período em que esteve em Nova Viçosa, sul da Bahia, difundindo e ampliando o conhecimento do trabalho do arquiteto e a cultura do saber-fazer em madeira nas áreas de arquitetura e design.

Acredita-se que a presença de diferentes métodos de fazer na obra de Zanine ampliará o horizonte projetual dos estudantes de arquitetura e design, permitindo uma avaliação das possibilidades criativas originais, porém sem desconsiderar o modo de construir moderno.

Para isso, fizemos uma ampla pesquisa bibliográfica, iconográfica e de campo que resultou, além desta dissertação de mestrado, em imagens e vídeos produzidos, a fim de desenvolver um trabalho que pudesse dialogar com um maior número de pessoas. Dessa forma, foi apresentado um vídeo na Bienal de Arquitetura de São Paulo de 2017, além de maquetes feitas de memória pelo Benedito, carpinteiro de Nova Viçosa que trabalhou com Zanine. Este trabalho também é uma maneira de retornar à comunidade de Nova Viçosa, cidade onde grande parte do trabalho de mestrado foi desenvolvida, enquanto uma contribuição para a ampliação do conhecimento da sua história e tradição construtiva a um maior número de pessoas.

Com este mesmo objetivo, apresentou-se um trabalho no $2^{\circ}$ Congresso Internacional de Design e Materiais, ocorrido em Joinville, cujo artigo completo encontra-se no link: < https:// proceedings.galoa.com.br/dm/trabalhos/jose-zaninecaldas-um-dicionario-do-fazer> , acessado no dia 22 de janeiro de 2018.

Além disso, este trabalho poderá influenciar estudantes das áreas de arquitetura e urbanismo a trabalhar com madeira e a resgatar conhecimentos tradicionais de construção, propiciando que o estudo de Zanine seja continuado e utilizado como base para trabalhos futuros, adquirindo uma existência autônoma. 



\section{capítulo 1 \\ Zanine e o \\ saber-fazer}





\section{Zanine e o saber-fazer}

Este capítulo é subdividido nas seguintes partes: Zanine e o saber-fazer; Belmonte; Rio de Janeiro e São Paulo na década de 1940; São José dos Campos e São Paulo na década de 1950; Primeira ida a Brasília; Casas na Joatinga; Segunda ida a Brasília. A divisão entre esses subcapítulos pretende facilitar a compreensão dos deslocamentos espaciais de Zanine e de sua obra, vinculando as atividades exercidas por ele a lugares e a momentos da sua vida.

Este primeiro capítulo é o resultado da pesquisa em jornais, livros, folhetos, documentários e filmes sobre José Zanine Caldas, com o intuito de reconstruir o seu percurso de vida, a fim de entender sua obra. Durante essas leituras, percebeu-se que uma busca constante no trabalho do arquiteto-designer foi a do saber-fazer. Utiliza-se esse termo inspirado na apresentação que a professora Maria Cecília Loschiavo dos Santos faz de Zanine:

(...) ele sempre foi o artifice, o fazedor, em oposição a outros artistas, designers, arquitetos seus contemporaneos. Ele é verdadeiramente uma figura dupla: o designer - artesão ou o arquiteto maquetista, que tem a experiência do saber-faz̧er, do trabalho da mão associado às ferramentas, ao traço, ao desenho. Este é um ponto fundamental em que se baseia toda a sua produção. Para ele este saber-fazer, este artesanato nunca esteve divorciado do projeto, ao contrário de muitos arquitetos de sua geração. (SANTOS, 1993, p.158)

Buscando descobrir as origens desse saber-fazer, este capítulo também discorre sobre questões históricas, culturais, etnográficas e materiais dos lugares em que Zanine esteve. Este ponto se torna importante porque o arquiteto-designer não frequentou uma faculdade, o que não o impossibilitou de criar obras que emocionam e que usam racionalmente a matéria-prima.

Figura múltipla, inquieto e curioso, Zanine desenvolveu diversos projetos, trabalhando como artesão, maquetista, designer, paisagista, arquiteto, planejador de cidades e professor. Deslocou-se no Brasil e fora dele na busca de novas experiências de trabalho, aprendizado, ensino e de vida. 
A fim de facilitar a compreensão dos deslocamentos de Zanine no território, vinculando-os ao trabalho que exercia em cada cidade, desenvolveu-se uma linha do tempo. A maior dificuldade na execução da mesma é o fato de que Zanine raramente ficou em um único lugar. Ele sempre se envolveu em mais de uma atividade ao mesmo tempo, quase sempre em lugares diferentes. Sendo assim, esta linha do tempo mostra os principais deslocamentos e atividades desenvolvidas por ele, mas acredita-se que Zanine esteve em outros lugares.

Como os capítulos 2 e 3 discursarão com profundidade sobre o período em que Zanine esteve em Nova Viçosa, não abordaremos este assunto no capítulo 1. 


\section{Legenda}

Ao lado há duas colunas. A primeira, em escalas de cinza, mostra as atividades exercidas por Zanine. A segunda, colorida, é o seu deslocamento pelo território.
Belmonte, BA

Rio de Janeiro, RJ

São Paulo, SP

São José dos Campos, SP

Brasília, DF

Nova Viçosa, BA

Paris, França

Vitória, ES

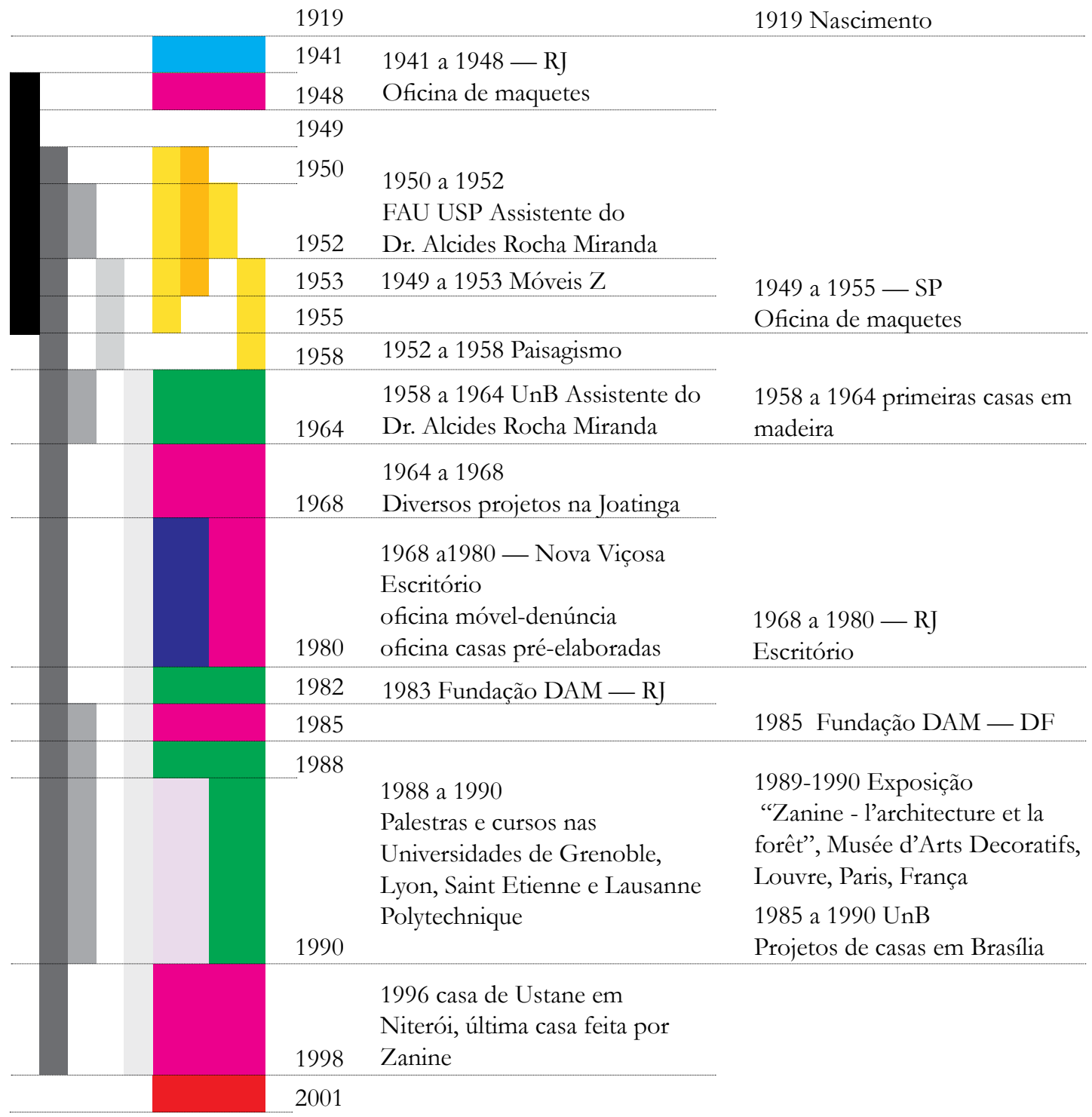




\section{Belmonte}

José Zanine Caldas (1919- 2001) nasceu em Belmonte (f.1 e f.3), uma cidade pequena no sul da Bahia, situada numa planície entre o Rio Jequitinhonha (f.2), antigo Rio Grande, e o Oceano Atlântico. Desde pequeno, observando os construtores da sua cidade natal, ficava encantado pela mágica do fazer. Ele mesmo comenta que

Com terra e madeira foram construidos os abrigos da humanidade. As casas de taipa e adobe de Belmonte, cobertas por telhas de barro cozido em fornos de barro com o calor da madeira no fogo. Foi por aí, exatamente, olhando o fazer, que aprendi a fazer, também. Sobretudo casas. (CALDAS apud SILVA, 1988. Não paginado)

Essa arquitetura sem arquiteto, que vincula o desejo de transformar a matéria-prima encontrada na região em abrigo a partir de um saber-fazer local, foi decisiva para sua formação como aquele que sabe fazer, que entende a necessidade da população e transforma os materiais naturais em objetos úteis para o dia a dia.

Esse saber-fazer observado por Zanine era popular e passava de pai para filho. Para entendermos sua origem, buscou-se descobrir os conhecimentos técnicos tradicionais dos moradores de Belmonte e de quais culturas poderiam ter vindo. Para isso, recorreu-se ao livro do Príncipe Maximiliano de Wied-Neuwied ${ }^{1}$, em que o escritor descreve sua chegada à vila de Belmonte entre os anos de 1815 a 1817, 100 anos antes do nascimento de Zanine:

Após fatigante e incômoda jornada sob a canícula e pelos animais estéreis e ardentes,

descortinamos jubilosamente, a tardinha, as comas ondeantes dos palmeirais em que a Vila

1 Maximilian Alexander Philipp zu Wied-Neunied (Neunied, 1782 - Neunied, 1867), foi um principe alemão que veio ao Brasil em 1815 para estudar a flora, a fauna e as populações indigenas. Passou dois anos pesquisando o litoral Brasileiro, desde o Rio de Janeiro, passando por Espirito Santo e indo até o sul da Babia. Nessa viagem coletou objetos etnológicos e utensilios de tribos indigenas, além de ter escrito um livro chamado "Viagens ao Brasil", no qual descreve suas impressões sobre os locais visitados. 
de Belmonte fica situada. É um lugar pequeno e mediocre, ora em caminho da decadência, fundado, cinquenta a sessenta anos atrás, com indios de que restam poucos atualmente. A casa da Câmara, feita de madeira e barro, estava a pique de ruir; uma parede caíra por completo, de modo que se devassava todo o interior. A vila forma uma praça com cerca de 60 casas, tendo aproximadamente 600 babitantes; a igreja fica numa das extremidades. As casas de residência são cabanas acachapadas feitas de barro; a única de alguma apresentação pertence ao "capitão mor", a do "ouvidor", na qual me deram pouso, não era melhor do que as outras. Quase todas as cabanas são cobertas de palha, e as ruas irregulares e sem calçamento, cheias de capim, tornam o lugar equivalente a nossas mais atrasadas aldeias; o unico ornamento está no número de coqueiros da planície arenosa, que por toda parte rodeiam as habitações, unindo as cimas ultimadas em um bosque farfalhante. Esses coqueiros são ai notavelmente produtivos; julga a população que rendem tanto por causa dos buracos feitos nos caules um pouco acima do solo... Belmonte possui três ou quatro lanchas, com que mantém, com a Babia, algum comércio de farinha de mandioca, algodão, arroz e madeiras de lei. A exportação anual de farinha de mandioca é de cerca de mil alqueires; o mesmo de arroz, dois mil de milho, e um pouco de aguardente, embora só haja aí duas destilarias. As margens do rio são férteis, pois que parcialmente inundadas, havia, nesse tempo, no lugar, um escocês que mantinha um comércio de algodão bastante desenvolvido; acabara justamente de perder um navio quase que inteiramente carregado, devido à conduta desleal do capitão. O pobre vilarejo tira agora alguma vantagem da comunicação feita com Minas Novas, na "capitania" de Minas Gerais, pelo rio e ao longo dele, mas, ainda assim, mal tem o indispensável à vida, sendo que nós, forasteiros, não conseguiriamos nada por dinheiro, se acaso não tivéssemos as mais urgentes necessidades satisfeitas graças ao nosso conhecimento com os moradores; entretanto, os "mineiros", de tempos a tempos, traziam em canoas, para o litoral, viveres e outros artigos, tais como milho, toucinho, carne seca, pólvora, algodão, etc., que supriam em parte a Vila de Belmonte e em parte eram mandados para Porto Seguro e Babia. (MAXIMILIANO, 1942, p. 225-26)

Esse primeiro trecho de texto conta como os abrigos eram feitos no início do século XIX em Belmonte, com o uso dos materiais encontrados no local: o barro, a madeira e a palha, e a partir de conhecimentos somados dos indígenas, negros e brancos. Uma cidade que, apesar de inicialmente pobre ${ }^{2}$, era um importante entreposto comercial por ficar à beira de um grande rio. Belmonte recebia visitantes da Europa para trocas comerciais, além de imigrantes africanos, portugueses, franceses e alemães, o que enriqueceu a cultura construtiva do local.

Naquela época, uma das formas mais importantes de circulação pelo território era através dos rios, principalmente no sul da Bahia, que tinha suas rotas terrestres habitadas pelos índios Botocudos ${ }^{3}$. Pelo Rio Jequitinhonha ligava-se Minas Gerais, centro

2. A situação econômica da cidade mudará com a plantação e o aumento da produtividade do cacau. 3 Botocudos eram indios considerados selvagens e que habitavam o litoral e o interior do sul da Babia. 
econômico que ganhou grande importância durante o ciclo do ouro (fim do séc. XVII até fim do XVIII) ao Oceano Atlântico.

A comunicação se realiza melhor pelo rio, em canoas, do que pela estrada. Várias delas, carregadas de produtos, descem anualmente de Minas, levando de volta, em geral, sal e outros artigos. São precisos perto de vinte dias para chegar às primeiras paragens habitadas de Minas, viagem sempre incômoda, ainda que Mawe a pareça ter imaginado mais fácil. Para o fim de proteger tais comunicações contra os selvagens ainda hostis, diversos postos militares foram estabelecidos rio acima, em direção a Minas: são em número de seis, Quartel dos Arcos, Quartel do Salto, Quartel do Estreito, Quartel do Vigia, Quartel de S. Miguel e dos Tucaios de Lorena. O primeiro é geralmente apelidado Caxoeirinha, devido às pequenas quedas d'água do rio vizinho, acarretadas pela presença de escarpas rochosas. A navegação fluvial traz certo arrimo à Vila de Belmonte; os habitantes, todos pescadores, são, à semelhança da maioria dos compatrícios, muito destros no manejo das canoas. (MAXIMILIANO, 1942, p. 227)

Maximiliano também se refere aos moradores da cidade de Belmonte:

Há em Belmonte uma raça peculiar de indios civilizados convertidos ao cristianismo, e conbecidos por indios "Meniens", que a si próprios, porém, se chamam "Camacans". Os remanescentes da antiga lingua, ora em extremo corrompida, testemunham-lhe a origem real, que eles mesmos conbecem bem. Outrora viveram rio acima, até que os paulistas (habitantes da "capitania" de S. Paulo) os rechaçaram dessa região, matando muitos. Os que escaparam fugiram para a vila, onde se estabeleceram. Aos poucos, abandonaram de todo o antigo modo de vida, sendo agora completamente mansos e em parte cruzados com a raça negra, alguns empregados como soldados, outros como pescadores e lavradores. Apenas uma minoria de gente velha ainda entende algumas palavras da antiga língua. São hábeis em trabalhos manuais, e fazem "esteiras", chapéus de palha, cestos, redes de pescar e redes menores para pegar caranguejos. São também bons caçadores, como todos os indios, mas há muito deixaram o arco e as flechas pela espingarda. (MAXIMILIANO, 1942, p. 227)

Como visto, pela sua posição geográfica estratégica, que conectava o interior do

\footnotetext{
Maximiliano os descreve assim: "A vista dos "Botocudos" causou-nos indescritivel espanto; nunca viramos antes seres tão estranhos e feios. Tinham o rosto enormemente desfigurado por grandes pedaços de pau, que atravessam no lábio inferior e nas orelhas, destarte, o lábio inferior fica muito projetado para a frente, e as orelhas de alguns pendem como asas largas sobre os ombros: os corpos bronzeados estavam completamente sujos. Já eram muito intimos do "ouvidor", que os tinha sempre em casa, a fim de lhes conquistar cada vez. mais a confianç. Dispunba de algumas pessoas que falavam a lingua dos Botocudos, e deixou-nos ouvir demonstraçoes de canto dos selvagens, parecido com um wivo desarticulado. Muitos deles tiveram varíla havia pouco: ainda estavam completamente cobertos de cicatrizes e crostas, que, somando-se à grande magreza trazida pela doença, aumentavam ainda mais a fealdade natural”. (MAXIMILIANO, 1942, p. 175)
} 
país ao Oceano Atlântico, Belmonte recebeu viajantes de São Paulo e Minas Gerais, permitindo trocas de mercadorias com o litoral e com a Europa. Recebeu imigrantes Portugueses que vieram para colonizar o litoral brasileiro e proteger o território contra ataques estrangeiros; africanos trazidos como mão de obra escrava, além de alguns poucos índios que sobreviveram e permaneceram.

Belmonte, que já plantava Cacau no início do século XIX, teve um grande desenvolvimento na sua plantação entre as décadas de 1890 a 1930. De acordo com o depoimento de Carmem Gomes ${ }^{4}$ (depoimento de 09/05/2018), enormes casarões eram construídos como resultado do crescimento econômico gerado pela colheita lucrativa do cacau; a cidade adquiriu uma importância econômica e política, e seu avô, o Coronel José Gomes de Oliveira, era o principal produtor de cacau. Com a intenção de tornar a cidade independente das cidades vizinhas e para criar uma elite com formação superior, o Coronel convidou médicos e advogados para morar na cidade. E foi assim que o médico Dr. Zanine Caldas chegou a Belmonte e, em pouco tempo, casou-se com Pálmide Gomes Zanine, uma das filhas do Coronel.

Dessa união nasceu José Zanine Caldas, na principal casa da cidade. Ainda de acordo com Carmem Gomes (depoimento de 09/05/2018), as principais festas, muitas das quais duravam dois dias, aconteciam nessa residência. As rosas do jardim, que vinham da Europa, eram usadas como decoração, mas não apenas nos dias de festa: a mesa de jantar estava sempre preparada com um belo arranjo de flores.

A partir desses fragmentos de texto, é possível imaginar o ambiente em que Zanine cresceu, aprendendo a construir casas de barro, assim como os ornamentados casarões de belmonte, observando o trançar dos cestos de palha e os arranjos de rosa que decoravam sua casa.

Eis que, possivelmente, ele percebeu que com a riqueza e a diversidade natural da região, somadas à habilidade manual e criatividade dos moradores, seria possível construir abrigos e objetos necessários ao dia a dia, tudo isso com extremo respeito e cuidado com a natureza.

4. Prima de José Zanine Caldas, pela parte da mãe. Entrevista realizada em 09 de maio de 2018. 
Acima, figura 1, fachada

da casa onde Zanine

nasceu. Abaixo, figura

2, Rio Jequitinhonba.

Fonte: Amanda Carvalho.
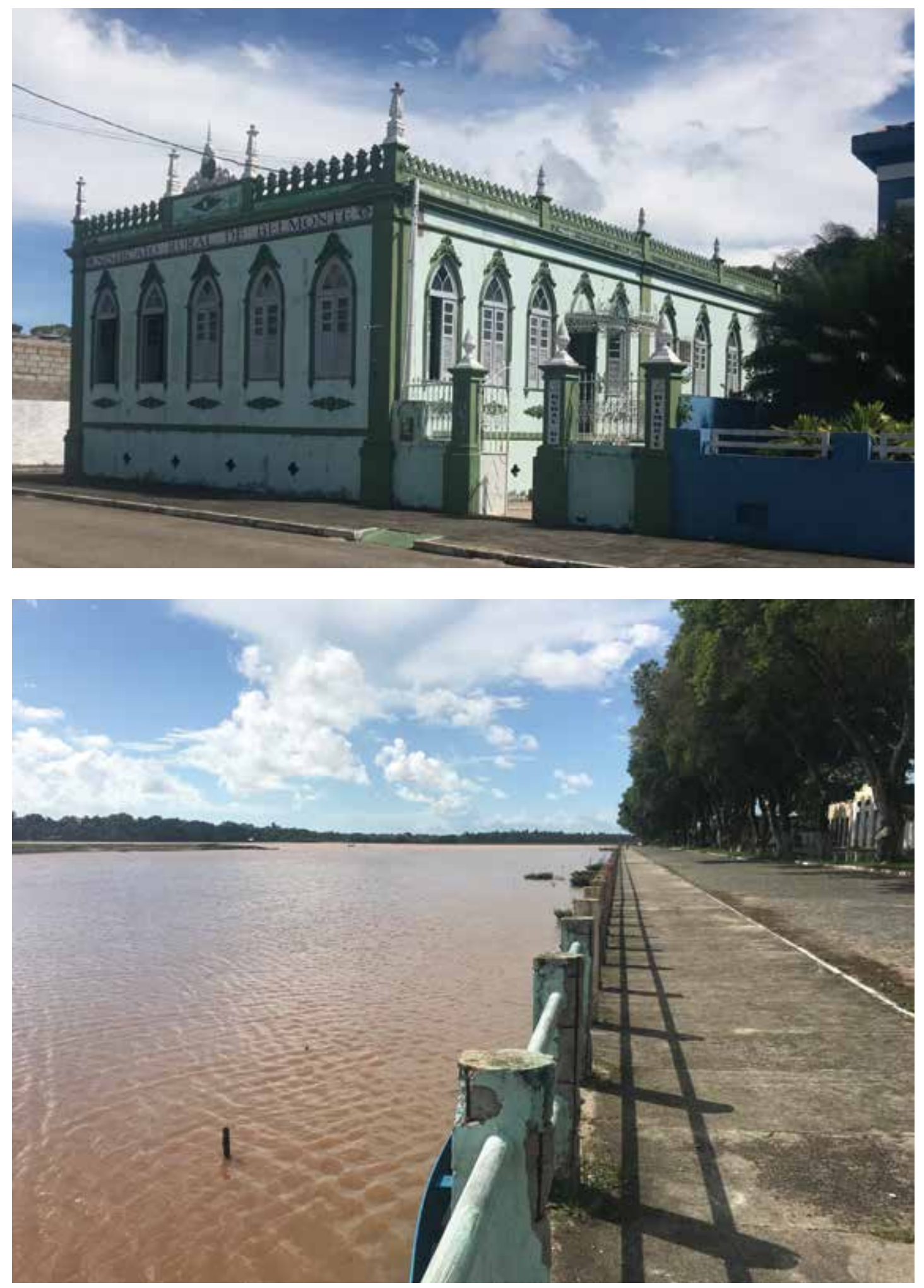
Figura 3, corredor lateral

da casa onde Zanine nasceu.

Fonte: Amanda Carvalho

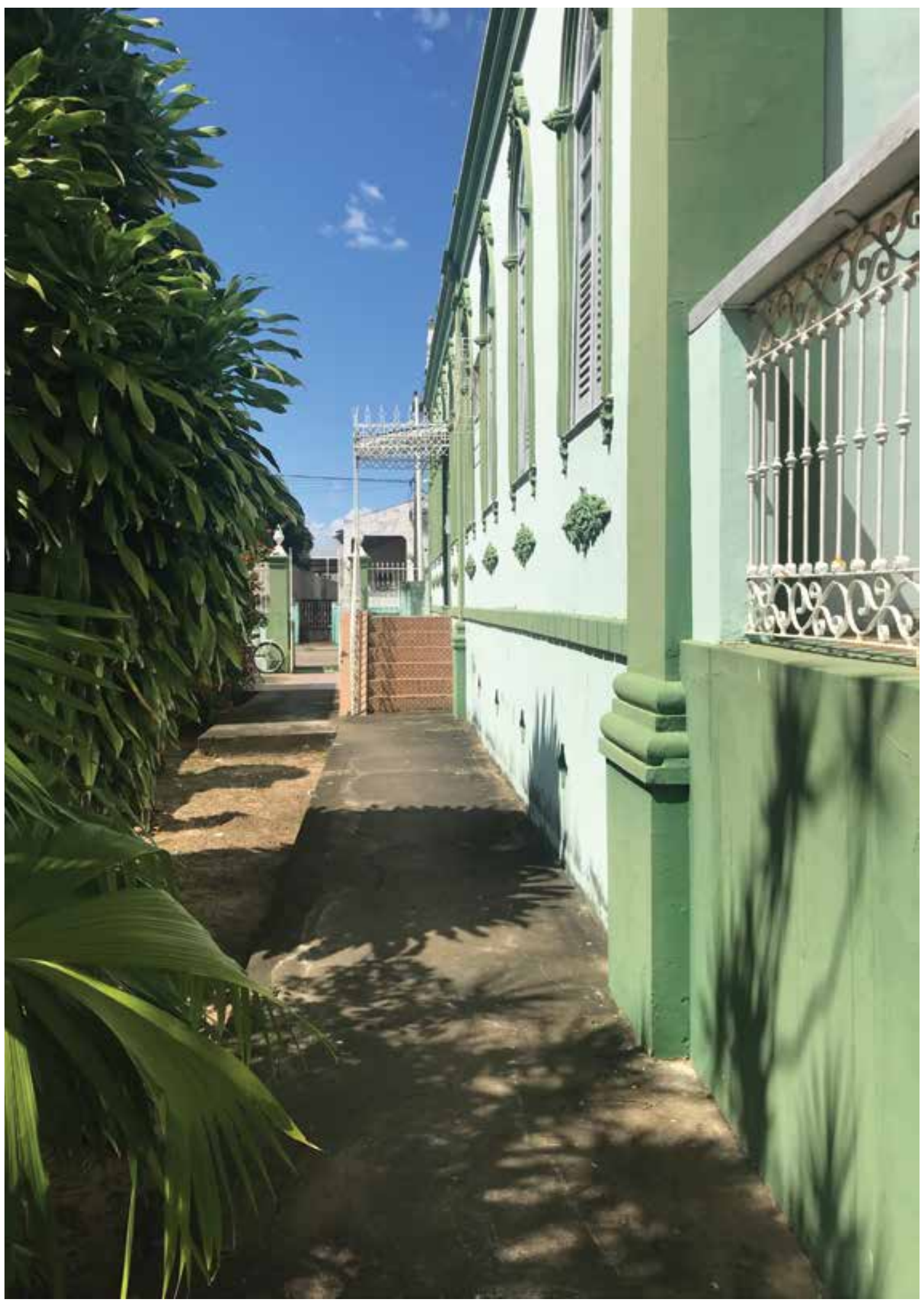




\section{Rio de Janeiro e São Paulo na década de 1940}

Com cerca de 20 anos de idade, Zanine foi para São Paulo trabalhar como desenhista de publicidade e de arquitetura, o que

Induz. uma ideia de dominio apurado sobre a arte de desenhar, uma vez que os padrões da linguagem publicitária dos materiais impressos do periodo estavam vinculados à capacidade comunicativa dos desenhos feitos à mão, já que o recurso fotográfico ainda não desfrutava de tecnologia adequada de impressão, além de ser reduحida a oferta de tipologias para a composição das mensagens publicitárias. (SANTOS, 1993, p. 49)

Para entendermos o panorama material e espiritual que Zanine encontrou em São Paulo e no Rio de Janeiro na década de 1940, é importante compreender as transformações ocorridas a partir de 1920, quando artistas e intelectuais, em plena comemoração do centenário de independência do Brasil, em 1922, pensavam sobre a construção de uma identidade nacional e fizeram a Semana de Arte Moderna em São Paulo.

Foi um período que despertou a vontade de unificação cultural do território brasileiro, com grande esperança no pensamento moderno, e, a partir de 1930, estas sensações se tornaram naturais e inconscientes entre os artistas, fazendo parte do seu projetar e pensar. Antonio Candido chamou esse processo de "rotinização" e diz que a década de 1930 foi um marco histórico:

Neste sentido foi um marco bistórico, daqueles que fazem sentir vivamente que houve um "antes" diferente de um "depois". Em grande parte porque gerou um movimento de unificação cultural, projetando na escala da nação fatos que antes ocorriam no âmbito das regiöes. A este aspecto integrador é preciso juntar outro, igualmente importante: o surgimento de condiçoes para realizar, difundir e normalizar uma série de aspirações, inovações e pressentimentos gerados no decênio de 1920, que tinham sido uma sementeira de grandes e inúmeras mudanças (CANDIDO, 1984, p. 27).

Dentre as transformações ocorridas no decênio de 1930, houve um alargamento de participação dentro do âmbito existente nos setores de instrução pública, vida artística e 
literária, estudos históricos e sociais, meios de difusão cultural como livros e o rádio.

Ainda de acordo com Antônio Cândido (1984), esse período foi significativo no ensino. Os educadores pressupunham a difusão da instrução elementar, para formar cidadãos capazes de escolher os seus dirigentes, aumentar as carreiras de nível superior, "visando renovar a formação das elites dirigentes e seus quadros técnicos; mas agora, com maiores oportunidades de diversificação social" "(CANDIDO, 1984, p. 28)

$\mathrm{Na}$ arquitetura, o decênio de 1940 ainda era permeado pelas questões levantadas nas décadas de 1920 e 1930, de formação de identidade nacional a partir de princípios universais adaptados a cada região, a cada povo e a cada nacionalidade. Além disso, a migração da população da área rural para a urbana aumentou o número de habitantes de muitas cidades brasileiras, trazendo para a pauta das discussões as questões de estandardização e de racionalidade construtiva.

Dessa forma, São Paulo e Rio de Janeiro, que se destacavam economicamente, receberam incentivos do Estado para serem aplicados em infraestrutura e na industrialização de produtos duráveis para o mercado interno, no intuito de formar uma indústria de base.

O aumento populacional das grandes cidades brasileiras, somado à consolidação das leis trabalhistas e ao acesso de maior parte da população à universidade, consolidou a classe média brasileira, formada por gerentes das indústrias, funcionários públicos das repartições recém-criadas pelo Estado na "Era Vargas" e o corpo de profissionais que se ampliava como advogados, médicos e comerciantes.

Foi neste período que Zanine chegou no Rio de Janeiro, em 1941, e abriu a “Oficina Maquete Studio José Zanine Caldas". Inicialmente sediada no Rio de Janeiro, mudou-se para São Paulo em 1949. Durante esse período, fez maquetes para grandes arquitetos brasileiros. De acordo com Segawa

Zanine foi um colaborador silencioso da elite da arquitetura moderna. Oscar Niemeyer, Oswaldo Bratke, Rino Levi e Vilanova Artigas, entre outros, contaram com os seus préstimos. Muitas das maquetes reproduæidas nas páginas do livro de Henrique Mindlin, Modern Architecture in Brazil, foram produzidas por Zanine. (SEGAWA, 2003, p. 15)

5 De acordo com Candido, (1984), bouve um aumento no número de escolas primárias. Apesar de as reformas na educaşão não gerarem mudanças essenciais na sociedade por não modificam a sua estrutura e o saber continuar mais ou menos como privilégio, a criação da Universidade de São Paulo em 1934 alterou o esquema tradicional das elites, com a ampliação dos grupos de elite com formação superior. "Houve assim uma espécie de "democratização" dentro dos setores privilegiados, com ascensão dos seus estratos menos favorecidos. Sem contar que algumas faculdades de filosofia e economia (estas, mais recentes) efetuaram uma relativa radicalização das atitudes e concepçoes, devido à difusão das ciências sociais e humanas, que levaram o espirito crítico a domínios onde reinavam a tradição e o dogmatismo" (CÂNDIDO, 1984, p. 29). 
Dessa forma, Zanine conquistou a credibilidade dos principais arquitetos do momento. Seu trabalho representou uma evolução formal e construtiva nas maquetes da época, que antes eram feitas esculturalmente, usando o gesso. Ele começou a usar o compensado laminado e outros materiais, que permitissem uma reprodução o mais fiel possível do edifício. Melo comenta o seguinte sobre entrevistas que fez com arquitetos modernos:

(...) um dos fatos citados foi a versatilidade no uso de diferentes materiais na composição da maquete, como a utilização de madeira-bálsamo, a simulação do papelão ondulado como telhas de fibrocimento, além do cuidado em desenhar sobre filmes transparentes representando as esquadrias de vidro. (MELO, 2001, p. 49 e 50)

Esse cuidado no fazer maquetes, transformou-a num instrumento de interpretação e investigação do projeto a ser realizado, colaborando para que, no ano de 1948, Zanine Caldas já fosse conhecido no meio profissional arquitetônico como um especialista em maquetes, tendo desenvolvido projetos para os mais importantes escritórios de arquitetura. Entre as diversas maquetes realizadas, constam projetos dos mais variados assuntos e alguns de repercussão nacional, tais como o Aeroporto Santos Dumont e o Ministério de Aeronáutica, vagões para a Estrada de Ferro Central do Brasil, Cia. Siderúrgica Nacional de Volta Redonda, Base Aérea de Manaus, levantamento Topográfico de Pampulha (Belo Horizonte), Copacabana Palace Hotel, Iate Clube do Rio de Janeiro, Palácio da Justiça do Distrito Federal, Residência Otávio Guinle em Teresópolis, Cidade Do Caxambú (Minas Gerais), Ministério da Educação, Ginásio de Cataguazes, Teatro Municipal de Belo Horizonte, Parque dos Afonsos, Sede do Jockey Clube do Rio de Janeiro, Hospital do Câncer e Maternidade São Paulo, ambos em São Paulo, Sanatório "Curicica” em Jacarepaguá, Hotel Manaus em Manaus (60), Residência Olivo Gomes e Centro Técnico Aeroespacial, estes dois últimos em São José dos Campos (SANTOS, 1993).

E provavelmente foi o sucesso adquirido entre os arquitetos modernos brasileiros que fez com que, em 1949, Zanine transferisse o seu estúdio de maquetes para São Paulo, onde permaneceu até 1955, executando aproximadamente 700 maquetes.

É importante notar que realizar maquetes de projetos de arquitetura é um dos primeiros passos para a materialização da ideia; é transformar o que antes estava em duas dimensões em três dimensões, em escala. Dessa forma, Zanine estudava e experimentava ideias projetuais desenvolvidas pelos principais arquitetos brasileiros da época. Essa materialização é um ótimo exercício de transferência de forças, análise espacial e formal, podendo-se dizer que Zanine, apesar de não ter frequentado uma Faculdade de Arquitetura e Urbanismo ${ }^{6}$, aprendeu muito durante a confecção das

6 Zanine não fer faculdade, como ele mesmo descreve, aprendeu observando os construtores da sua cidade natal, Belmonte. Apesar disso, pode-se dizer que aprendeu arquitetura na prática, executando em 3 dimensões os projetos dos principais arquitetos da época, e, também, durante as conversas com os 


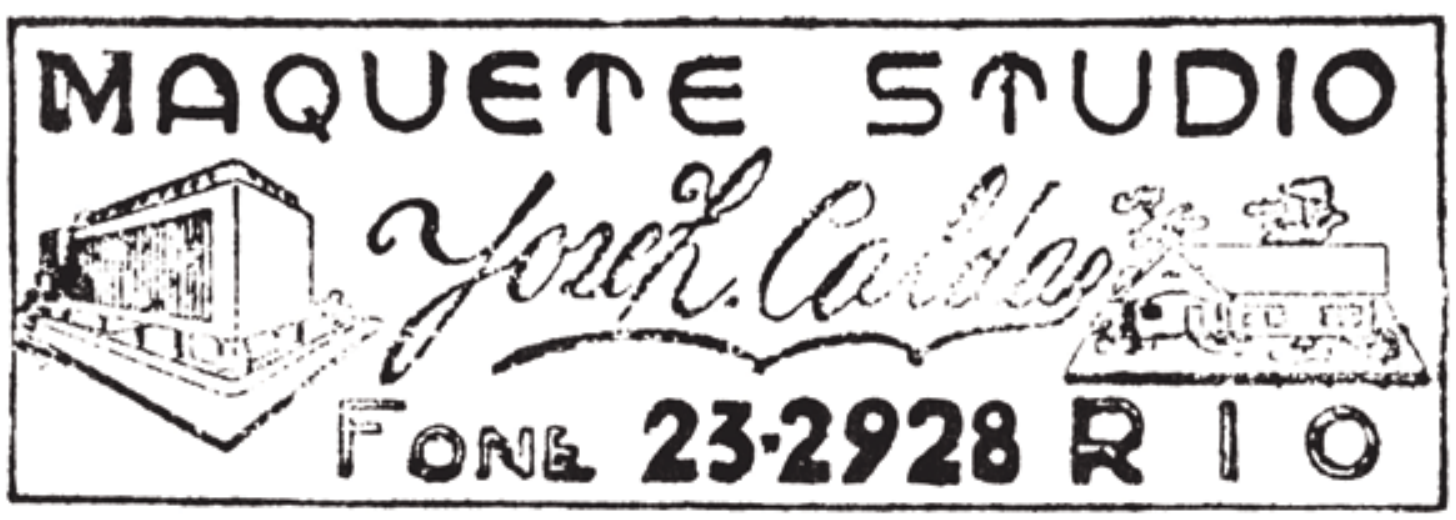

Figura 4, Carimbo da Oficina de Maquetes de Zanine no Rio de Janeiro. Fonte: SILVA, 1988, não paginado. 
maquetes e durante as conversas com arquitetos. Em testemunho de Lúcio Costa, ao materializar os desenhos, havia momentos em que o próprio Zanine solucionava problemas apresentados:

... interessante é que ele comeģou com o negócio de maquete, faz̧endo trabalhos para os arquitetos, a partir de coisas bem menores, até projetos mais complexos. Por isso, não o acho um autodidata, mas um profissional com larga experiência, formado na construção, que ele transformava em miniaturas em três dimensões. O que o arquiteto fazia em forma de desenho, ele realizava como arquitetura em si: a coisa como é, em três dimensões, verdadeiras aulas. Quando os projetos the eram submetidos, ele resolvia, ao faz̧er, as maquetes, vários problemas, até faz̧endo pequenas correções. Seu trabalho era de colaboração. Queria chamar a atenção para isso. Depois, chegou o momento em que, em vez, de fazer a miniatura de projetos dos outros, ele passou a fazer, em tamanho natural, projetos dele mesmo. Abandonou o brinquedo para fazer suas próprias obras. Ai virou o Zanine. (CALDAS apud SILVA, 1988. Não paginado).

Durante o período de aproximadamente 13 anos em que Zanine fez maquetes, participou das discussões do grupo de arquitetos que, sob a orientação de Lúcio Costa, acreditava nas possibilidades democráticas da produção em massa. O momento de modernização cultural e econômica era oportuno para colocarem em prática suas ideias:

O desenvolvimento rápido da nova arquitetura não é tampouco uma consequência exclusiva das condições politicas da época, mas, em última análise, uma consequência das condições econômicas anormais: prosperidade econômica devido à guerra e à inflação. As construções eram então realizadas um pouco por toda a parte, ao acaso, segundo a march a frenética da especulação. Em 1951, calculava-se que em São Paulo, em uma hora, construiam-se quatro casas e meia (PEDROSA, 2003, p. 101 in XAVIER, Alberto).

Essas transformações políticas e econômicas, que atraíram imigrantes e moradores rurais para os grandes centros urbanos, somadas ao surgimento da classe média brasileira, colaboraram para a construção do apartamento residencial. Morar nesses apartamentos significava um novo modo de vida. Além de uma necessidade de adaptação a espaços menores, havia uma busca por leveza, mobilidade e flexibilidade nos mesmos.

Participar das discussões sobre habitação faz pensar sobre o mobiliário, sobretudo quando os principais arquitetos do Brasil repensavam a forma de viver, de morar, o que

mesmos, nas quais discutiam sobre soluções projetuais. Pode-se dizerer que Zanine aprendeu em Belmonte a técnica tradicional de construção do Brasil, em grande parte traz̧ida pelos imigrantes, e que estudou criação e composição espacial com os arquitetos modernos. Também podemos afirmar que sua infância em Belmonte fez. com que admirasse os construtores, permitindo um olhar atento e curioso para o seu saber-fazer, sem o qual não assimilaria esse conbecimento. 


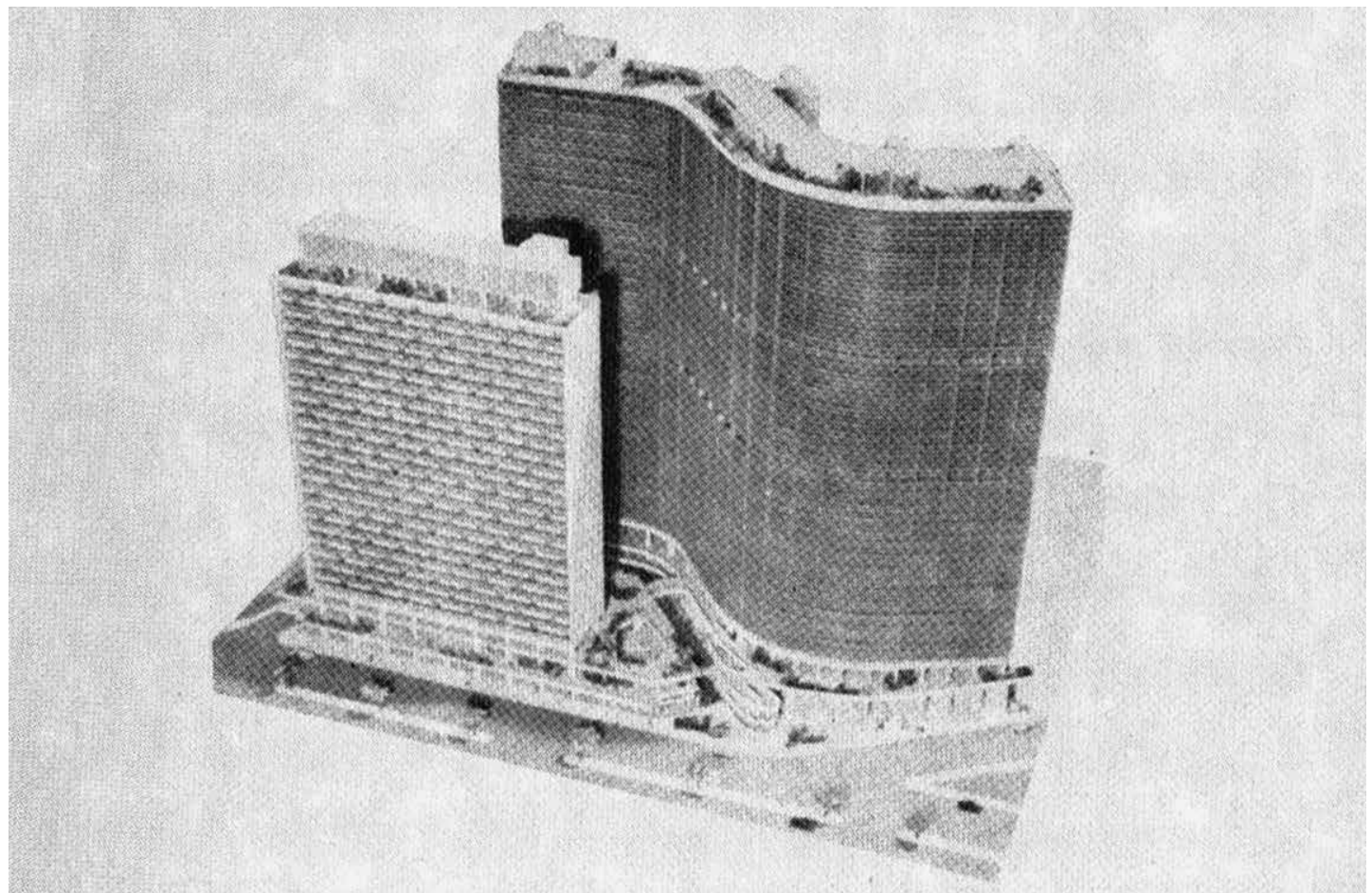

Figura 5. Maquete do Copan. Fonte: Silva, 1988, não paginado.

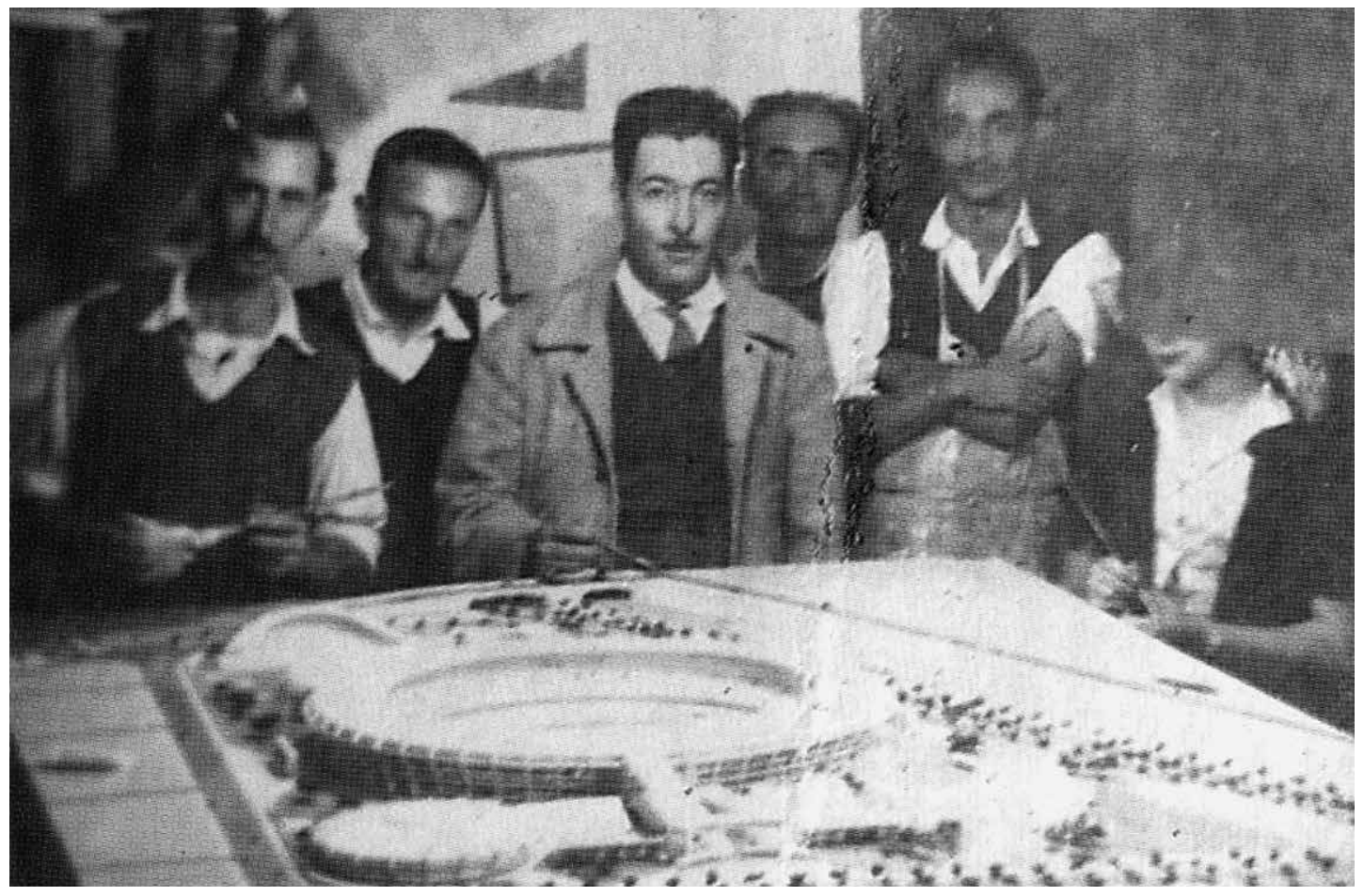

Figura 6. Maquete do estádio Maracanã. Fonte: Silva, 1988, não paginado. 
pressupõe um mobiliário diferente. Além disso, a crescente demanda por habitações, e consequentemente por móveis, causada pelo crescimento populacional, questionava as formas de produção moveleira. A produção nacional não supriria a quantidade necessária de peças no tempo necessário. Todos esses questionamentos já estavam colocados pelos arquitetos modernos na década de 1930 e 1940, mas haviam raras experiências de industrialização do mobiliário.

Na década de 1920, alguns artistas, como o Lasar Segall e John Graz, repensaram o interior das casas brasileiras e desenharam alguns móveis, mas eram peças únicas, com a intenção de modernizar e compor o ambiente interno das residências. Ainda nesta época alguns arquitetos, como o Warchavchik, também desenharam móveis. Tinham a mesma intenção modernizadora dos artistas decoradores, mas, apesar de serem peças únicas, já carregavam um pensamento de fabricação em série. Segundo Santos (1993), as primeiras experiências de mobiliário que usaram novas técnicas produtivas na indústria brasileira foram a Fábrica de Móveis Carrera (1909-1918), a Indústria Cama Patente L. Liscio S. A. (1919-1968) e a Cia Industrial de Mobiliário - CIMO (1919-1939). 


\section{São José}

dos Campos

e São Paulo na

década de 1950

Como já falado anteriormente, o final da década de 1940 e início da de 1950 foi um período em que o Brasil passava por um processo de industrialização, abrindo perspectiva de ampliação para o mercado brasileiro produtor e consumidor. Nesse contexto de transformação, em que os móveis desenvolvidos pelo Liceu de Artes e Ofícios já não respondiam ao gosto, necessidade e velocidade da vida moderna, Zanine Caldas decidiu abrir em sociedade com Sebastião Henrique da Cunha Pontes (19111978) e Paulo Mello (1922-1982) a Fábrica de Móveis Z, em São José dos Campos, em 1949 (Melo, 2001).

Com a Fábrica de Móveis Z, Zanine foi um dos pioneiros a desenhar e produzir móveis manufaturados e a utilizar o compensado naval para execução dos mesmos. Não se pode falar que a produção da fábrica era industrial — havia muito trabalho manual —, mas, apesar disso, pela industrialização ainda ser recente no início da década de 1950, houve espaço para que pequenas empresas e oficinas fossem criadas, uma vez que o maquinário mais avançado para o trabalho com a madeira era introduzido no país (SANTOS, 1993).

Segundo Santos (1993), a montagem das peças era extremamente simples, o que permitiu a utilização de mão de obra não especializada nessa função. Com isso, a fábrica de móveis $Z$ conseguiu reduzir entre $70 \%$ a $80 \%$ o preço da mobília, em relação ao que era feito com madeira comum. Sua fábrica tinha em torno de 150 funcionários e vendia muito:

Toda a linha de móveis era modulada e possibilitava a composição de arranjos de acordo com as necessidades do cliente. Os assentos utilizavam as molas nozague e estofamentos forrados com tecido sem costura - lona, lonita ou materiais plásticos coloridos azul, amarelo, marrom on listrados - fixados por baixo com grampos ou tachinhas e uma placa de compensado para dar certo acabamento. Aliás, a presença da cor e da assimetria na composição dos móveis de Zanine é um aspecto inovador para a época, pois até então as superfícies dos móveis eram praticamente neutras, sóbrias e simétricas. Em alguns móveis apresentava-se um jogo cromático decorrente da combinação dos próprios materiais, como vimos, por exemplo no trabalho de Tenreiro e que voltou a emergir com muita expressão na obra do designer Maurício Azeredo, nos anos 80, na 
cidade de Pirenópolis, Goiás. Sob este aspecto, Zanine foi muito além dos limites da produção brasileira de seus contemporâneos, aproximando-se das concepções de estética industrial então correntes na Europa. (SANTOS, 1993, p. 167)

A redução do valor da mobília em comparação com os móveis anteriormente desenvolvidos pelo Liceu de Artes e Ofícios e também em relação a outras fábricas de móveis modernos do período, fez com que os Móveis $Z$ chegassem às casas da recente criada classe média brasileira.

Segundo Melo (2001), a escolha formal dos móveis de Zanine demonstra que ele conhecia o que era produzido fora do país nas décadas de 1930 e 1940, quando surgiu nos círculos artísticos as formas livres como crítica ao desenho racionalista. Essas informações podem ter chegado ao conhecimento do arquiteto por meio da importação de jornais e revistas estrangeiras, mas também pela abertura de lojas de móveis que expunham peças produzidas por Alvar Aalto no final da década de 1940 em São Paulo. As formas definidas por Zanine para seus móveis eram formas orgânicas, possibilitadas pelo uso do compensado de madeira.

Apesar da produção mais simples do que a internacional, sem o uso da prensa para fazer móveis de compensado moldado, segundo Melo (2001), as peças desenhadas por Zanine tinham formas livres, que precisavam ser recortadas na tico-tico, processo que exigia grande concentração do trabalhador, com perda de material e de tempo no recorte das peças em relação a cortes retos.

Outra característica da Fábrica de Móveis Z é a das publicidades em revistas da época (f.7), o que remete a uma das primeiras atividades desenvolvidas por Zanine quando chegou em São Paulo: desenhista de anúncio de publicidade. Esse fato demostra que colaborou com o seu conhecimento de publicidade na produção dos anúncios da Fábrica de Móveis Z. Eles eram compostos, na grande maioria, por imagens de espaços residenciais maleáveis, decorados com móveis coloridos e de formas sinuosas.

Internacionalmente, a metade da década de 1950 foi marcada pelo fim dos Congressos Internacionais de Arquitetura Moderna (CIAM), e por uma desconfiança de que a tecnologia e a ciência não conseguiriam transformar a humanidade e melhorar a vida do homem. O próprio Zanine desiludiu-se da ideia de que a Fábrica de Móveis Z possibilitaria que a população tivesse uma casa melhor mobiliada, bem como melhores condições de vida. Talvez esse também tenha sido um dos fatos que o levou a sair da sociedade da fábrica. De acordo com Ethel Leon, Zanine acreditou na industrialização, mas acabou se decepcionando com os industriais, uma vez que os sócios da Móveis Z não queriam inovar a produção, pensando mais nos lucros: "Eles estavam ganhando muito dinheiro e era só o que interessava. Não consigo ser assim, sempre preciso me aprimorar. Acabamos nos desentendendo e sai" (CALDAS apud LEON, 1989, p. 138).

Zanine ficou na sociedade até 1953, quando se afastou da empresa e queimou seus desenhos de móveis que ainda não tinham sido fabricados. A fábrica continuou suas atividades por mais alguns anos, parando sua produção após um grande incêndio. 
Figura 7. Publicidade

da Fábrica de Móveis Z.

Fonte: Casa e Jardim, 1953,

V.3, p. 9 .

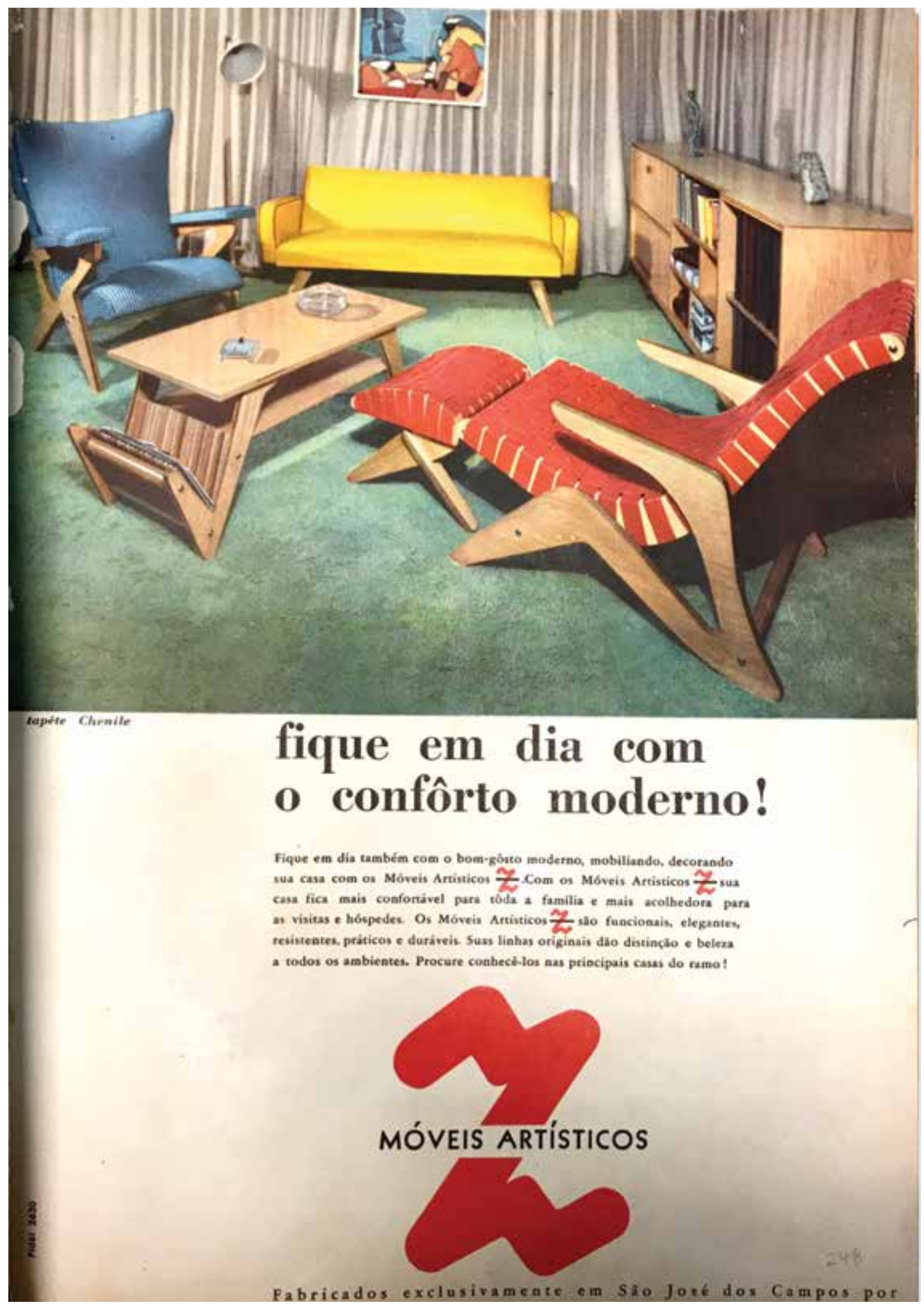


Provavelmente datam do período em que esteve em São José dos Campos as primeiras residências de Zanine, ainda sem o uso predominante da madeira, característica marcante do arquiteto. Melo (2001), ao descrever os arquitetos que trabalharam em São José dos Campos, fala sobre essas casas projetadas por Zanine na cidade:

[...] um dos mais versáteis profissionais que se instalaram em São José dos Campos na década de 50. Maquetista especializado e desenhista de móveis, inicion aqui sua carreira como arquiteto (autodidata) projetando suas primeiras residências ainda sem a presença maciça da madeira, que the conferiu posteriormente notoriedade internacional. Foi um dos fundadores da Fábrica de Móveis Z (Zanine \& Pontes). (MELO, 1997, p. 219)

A afirmação de que Zanine começou a fazer casas em São José dos Campos foi confirmada durante entrevista com o professor Júlio Katinsky:

E ai ele comecon a fazer umas casas numa ponta de terreno lá no Rio de Janeiro. Porque antes ele fez umas casas em São José dos Campos, dentro daquilo que ele conbecia dos arquitetos modernos Brasileiros. E essa parte ninguém conhece. (KATINSKY, entrevista, 27.06.2016)

Melo mostra, em seu livro Arquitetura Moderna em São José dos Campos, a Residência Sebastião Pontes (f.8 e f.9), localizada à Av. Anchieta, 33 - Jd. Nova América e projetada por Francisco Victor Palma e José Zanine Caldas.

Uma das primeiras residências a serem construidas no Jardim Nova América, esta obra localizada em um terreno de esquina, o que permitiu ao arquiteto adotar um partido formal pouco utilizado no inicio da década de 50. Disposta em forma de "Y", a residência apresenta três blocos, sendo a cozinha o ponto de convergência destes. O bloco social é representado pela sala de estar e jantar com afresco de Sotto Mayor, e os dormitórios estão dispostos de tal forma que suas testadas possuem orientação para o Banhado. Vale lembrar que, após a inanguração do Jardim Nova América, nenbuma edificaşão poderia ser construída na orla do Banbado, caso se constituísse barreira visual aos passantes ou moradores. A área de serviço teve sua orientação voltada à via secundária, liberando o terreno para formação de um belo jardim. A disposição volumétrica, em decorrência da forma adotada pelo arquiteto, agregon duas qualidades à obra: a insolação constante de todos os ambientes e a diferenciação de fachadas para cada via. Esta obra teve sua ornamentação realizada por Zanine Caldas, que se instalou na cidade por motivos de saúde e também para a prestação de serviços ao CTA. Zanine adotou as pastilhas policromáticas e quebra-sóis metálicos para o revestimento da fachada, além de criar algumas gravuras para as cerâmicas de revestimento da platibanda. (MELO, 1997, p. 115)

Essas casas de São José dos Campos ainda não eram projetadas em madeira, material que tornou Zanine conhecido. Formalmente elas seguiam o ideário modernista 


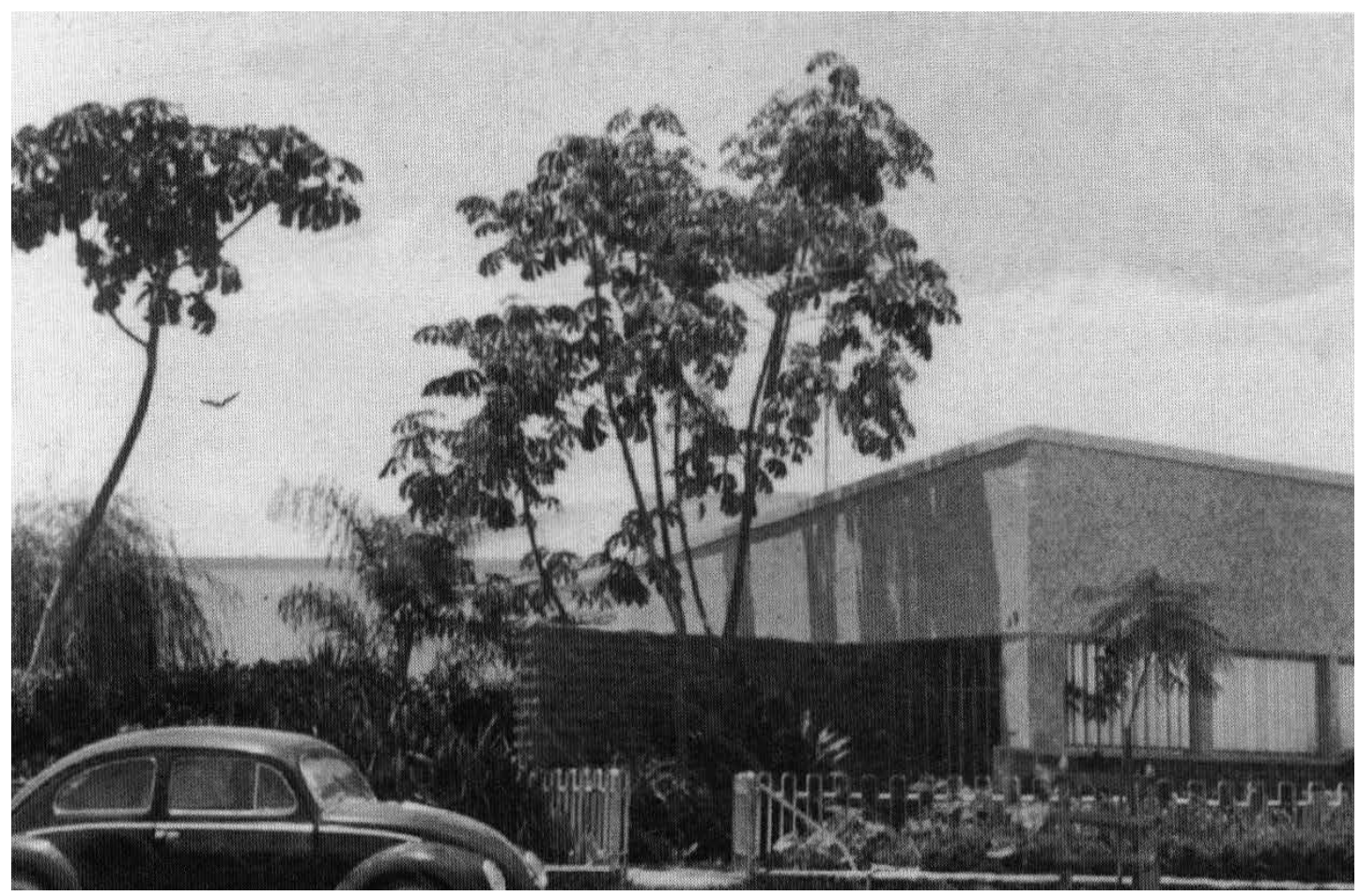

Figura 8. Residência Sebastião Pontes. Fonte: MELO, 1997, p. 116.

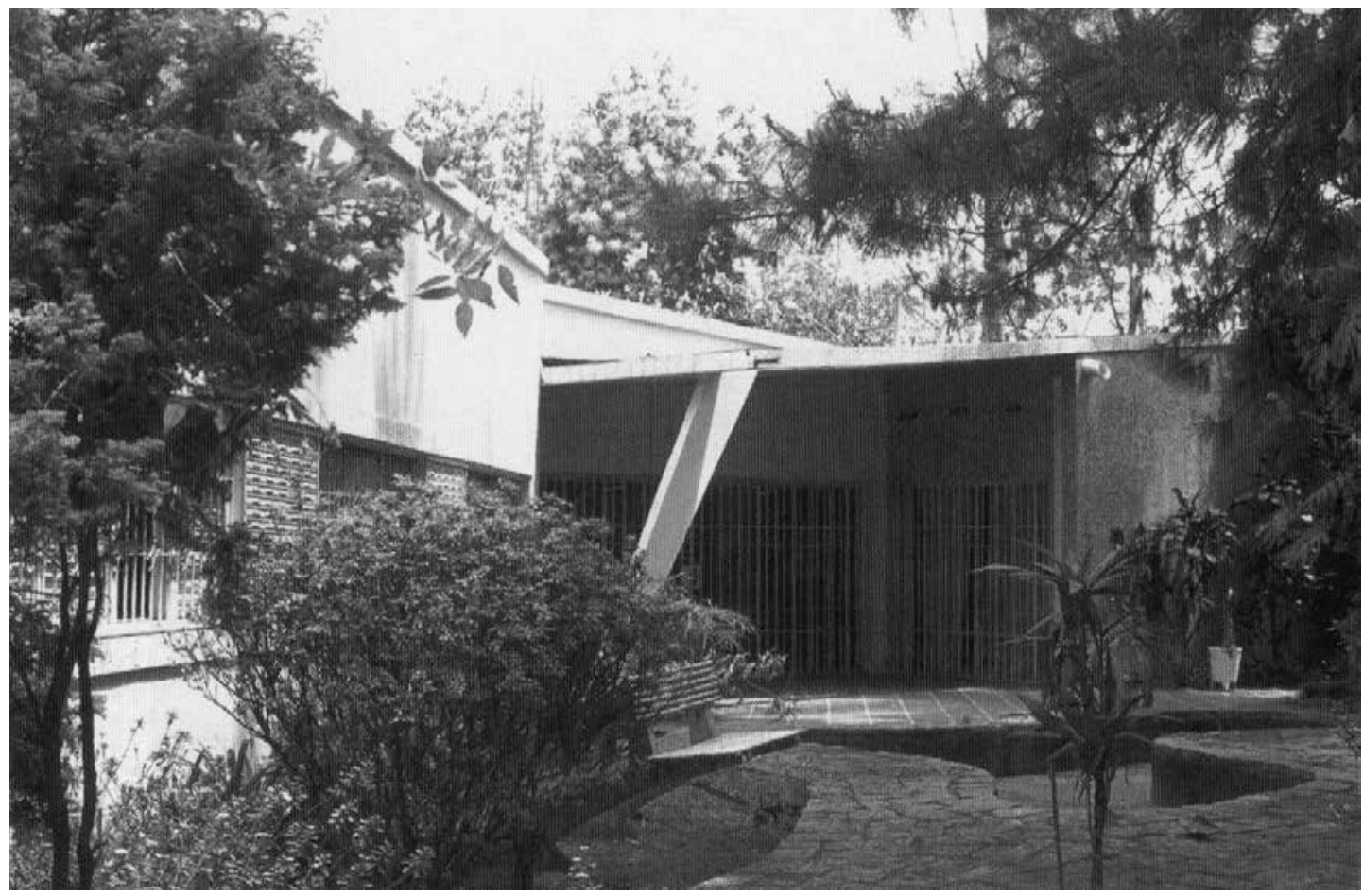

Figura 9. Residência Sebastião Pontes. Fonte: MELO, 1997, p. 116. 
da época, muito inspiradas nos arquitetos com os quais Zanine trabalhou desenvolvendo maquetes, tais como Alcides da Rocha Miranda, Oswaldo Bratke, Rino Levi e Niemeyer.

Em 1951, Zanine foi convidado para montar o laboratório de maquetes, atual Laboratório de modelos experimentais (LAME) da recém criada Faculdade de Arquitetura e Urbanismo da Universidade de São Paulo ${ }^{7}$ (FAU-USP), atividade que exerceu por curto período de tempo:

Foi por sugestão do arquiteto Alcides da Rocha Miranda, durante sua permanência como professor de Plástica de Arquitetura e Urbanismo na FAU que, em 1951, o então diretor, Luiz. Ignácio Romeiro de Anhaia Mello, contratou Zanine para a criação do Atelier de Maquetes, desenvolvendo-se assim uma experiência pioneira nas áreas do ensino e da prática do desenho industrial dentro da Universidade, uma vez que a Sequência do Desenho Industrial somente foi criada em 1962, onze anos depois. (SANTOS, 2015, p. 149)

$\mathrm{Na}$ FAU-USP ele foi contratado como técnico, mas sua atividade era de professor: ensinava os estudantes a construírem maquetes (f.10 e f.11), procedimento de experimentação, pesquisa e estudo fundamental na formação de arquitetos, urbanistas e designers.

De volta a São Paulo, desenvolveu uma pesquisa na área de paisagismo entre os anos de 1953 a 1958, contando com o apoio do arquiteto Luis Saia (SANTOS, 1992). Também nessa época ele fez jardins para residências, como o da residência Guilherme Hannud, projetada por Luis Saia, no bairro do Morumbi, São Paulo (f.13 e f.14).

No jardim externo dessa residência ele utilizou dracenas. Na pérgola, utilizou trepadeiras; no jardim interno, fez uma composição com variedades diversas de plantas que, como visto nas fotos, encontram-se espalhadas pelos cômodos em diversos vasos.

Segundo Yvonne ${ }^{8}$, em reportagem para o jornal Folha da Manhã, Zanine tinha um viveiro para cuidar das suas plantas, assim como para fazer mudas. Além disso, desenvolvia vasos de cerâmica, desenhados não para servirem apenas como objetos de decoração, mas para que a planta se desenvolvesse melhor, ficando protegida contra o ataque de formigas, assim como possibilitando arranjo entre folhas e flores:

As formigas podem atacar a planta que quer colocar nesta cuia grande? Em vez de po-la sobre uma tigela cheia d'água. Porque não criar logo uma forma que resolva o problema: uma espécie de tigela na qual a cuia ficará embutida? A forma geral desse vaso ficará prejudicada se colocarmos um pires abaixo dele? Por que não cavar a parte de baixo de modo a permitir a colocação interna de uma tigelinha menor que permanecerá invisivel? Há quem goste de cultivar

7 A FAU-USP foi criada em 1948, a partir do curso de engenharia da Escola Politécnica da Universidade de São Paulo (POLI-USP).

8 Jornalista, escreveu sobre jardins para a Folha da Manhã. 

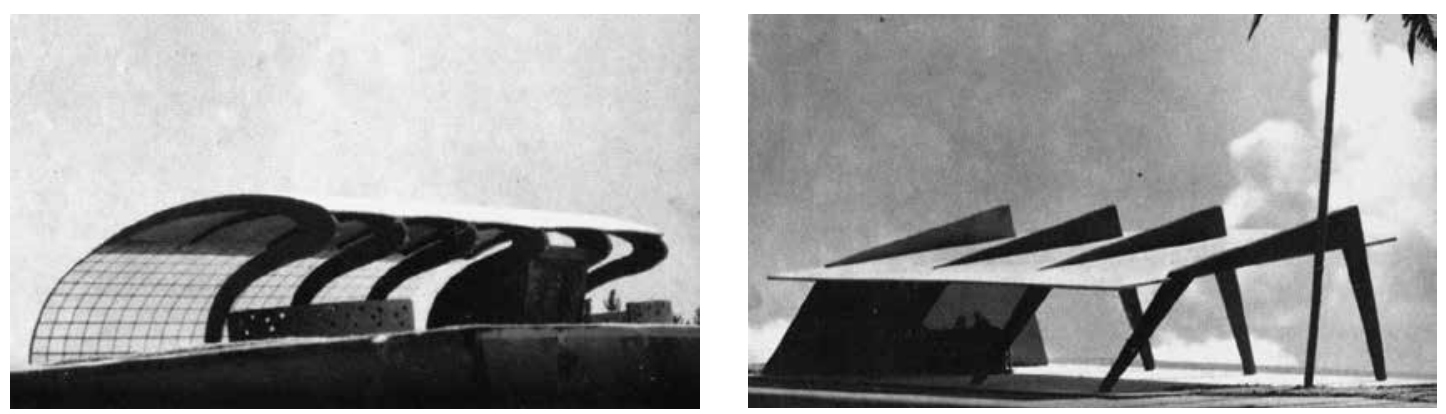

Figuras 10 e 11. Maquetes feitas por estudantes da FAU USP, orientados por Zanine. Fonte: SILVA, 1988, não paginado.

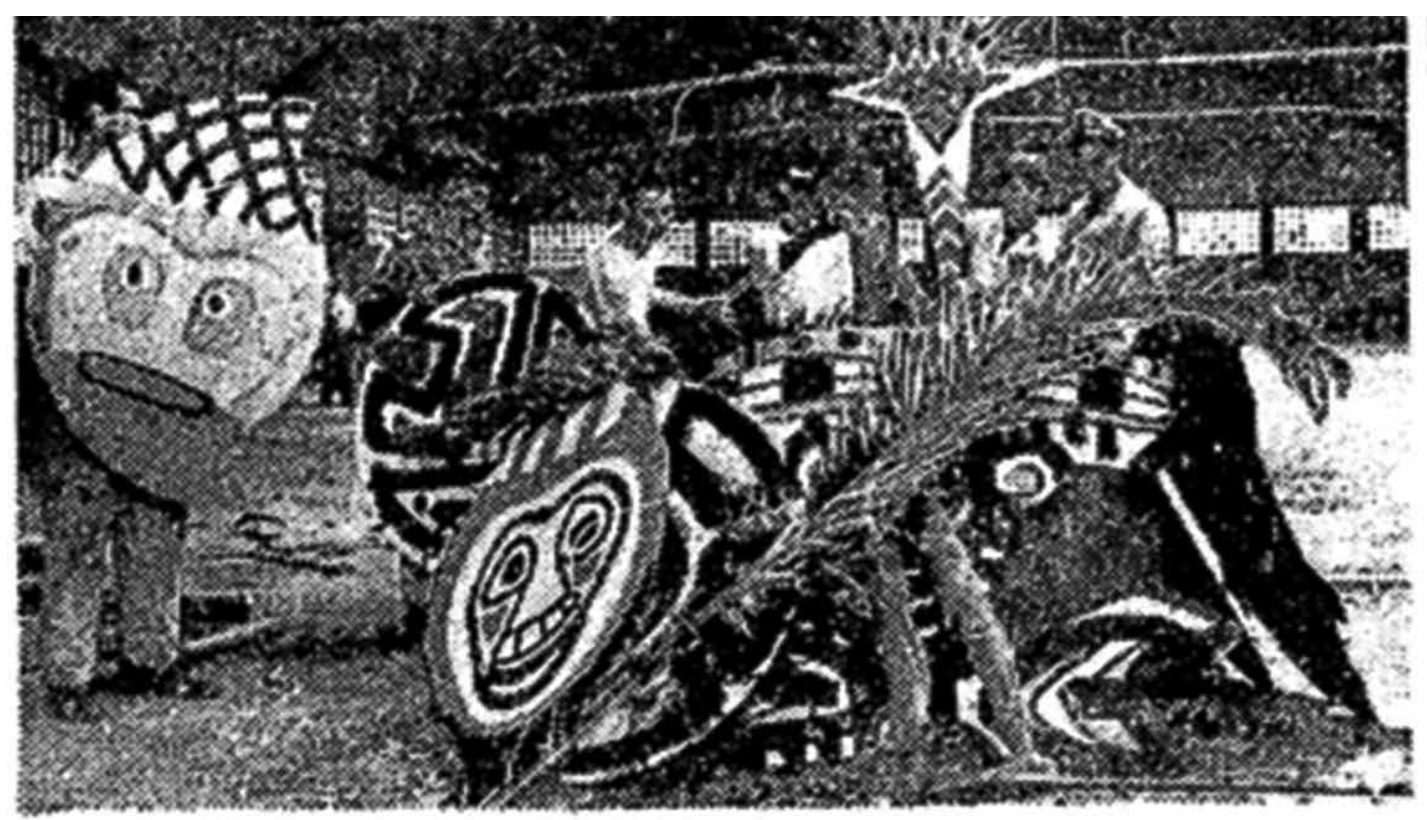

ORNAMENTACAO PARA O CARNAVAL - Comecará hoje a ornamentaça da cidade para o carnaval. Segundo informaçōes do gabinete do prefeilo, os seguintes locais sertio principalmente visados na caracterizaçāo para os dias de Momo: parque Ibirapuera, avenidias Ipiranga e Sáo João (esta da praça Julio Mesquita até a praça do Correiol, rua Baräo de Itapetininga $e$ praças Ramos de Azevedo e Roosevelt. Sessenta homens da Divisáo de Parques e Jardins seráo empregados nos trabalhos de confeç̧̄o e montagem dos fantoches, bonecos, mascaras, floröes e lampadas coloridas. A ornamentação será concluida sabado, dia em que, extraoficialmente, comeca o carnaval e deverá custar 200 mil cruzeiros ¿ Prejeitura. O paisagista José Zanine, sunervisiona o plano dos trabalhos e conta com a colaboracío de numerosos artistas plasticos e pintores.

Figura 12. Ornamentação para o carnaval. Fonte: Folha da Manhã, 27 Fev 1957 Cad. Assuntos Gerais, p. 1. 
plantas diversas? Em vez de alinhá-las em vasos pequenos porque não criar um suporte para três plantas e fabricar seis potes para ele: assim metade das plantas embelezará a casa enquanto a outra apanhará luz no jardim. (CALDAS apud Yvonne, 1956, p. 51)

Ainda de acordo com Yvonne (1956, p. 51), além dos jardins particulares, ele também se dedicou aos jardins públicos das cidades do interior. Fez os jardins de Itu e de Lins e a praça de São José dos Campos. Para essa, adotou um sistema interessante: pediu aos habitantes que o ajudassem, oferecendo plantas à prefeitura. Muitos que possuíam mudas, principalmente os fazendeiros, atenderam ao pedido, embora a população se encontrasse desconfiada: não acreditavam na beleza de um jardim criado com "plantas vulgares". Nos seus jardins ele utilizava muitas plantas autóctones, tanto nos projetos residenciais como nos públicos.

Na sua loja-ateliê da Rua Augusta, nos fundos de uma casa, Zanine aproveitava objetos simples que encontrava nas viagens para o interior do estado, como balaios e gamelas, tachos e proteção de garrafas, raízes e galhos para criar seus vasos e arranjos. Essa atitude de reaproveitamento será retomada mais adiante na obra do arquiteto, quando reutilizou peças de demolição para construção de casas na Joatinga.

Mais do que um ateliê, na Rua Augusta ele desejava criar um local de encontro, um lugar onde as pessoas pudessem observar as plantas e as cerâmicas, conversar e reunir-se.

Não penso tão somente em vender, mas também em criar um ambiente para quem ama as plantas. Outra razão pela qual abandonei a loja é que, por toda parte, surgiram imitadores que criavam ceramicas puramente comerciais, nelas colocavam umas plantinhas e chamavam o conjunto de moderna. Eu não tenho destas pretensões. Jamais criei peças de grande valor artístico à maneira de uma Elisabeth Nobiling", por exemplo. Quero tão somente, criar formas adaptadas às necessidades das plantas. Não dou mais, hoje em dia, importância à forma em si. Sempre penso em função da planta. Assim, formas atuais que utilizo são muito simplificadas, mais puras para que a atenção se focalize sobre a planta que deve realçar. (CALDAS apud Yvonne, 1956, p. 64)

Preocupado com a utilidade, Zanine fez muitas cerâmicas com formas mais fechadas que as habitualmente destinadas às plantas, pois a aberta requer que se esconda a terra do fundo com musgo ou pedrinhas.

Depois de sair da casa na Rua Marquês de Itu, no Bairro de Higienópolis, São Paulo, onde fazia as maquetes, foi morar em um terreno arrendado, oferecido por Oswaldo Bratke, detrás da casa do próprio arquiteto, onde viveu por cinco anos. Nesse

9 Olga Elisabeth Magda Henriette Nobiling (São Vicente, SP, 1902 - São Paulo, SP, 1975). Escultora, ceramista e desenhista. Entre 1929 e 1930, é admitida na Academia de Belas Artes da Universidade de Berlim. Também atuou como professora na FAU-USP em 1953. 


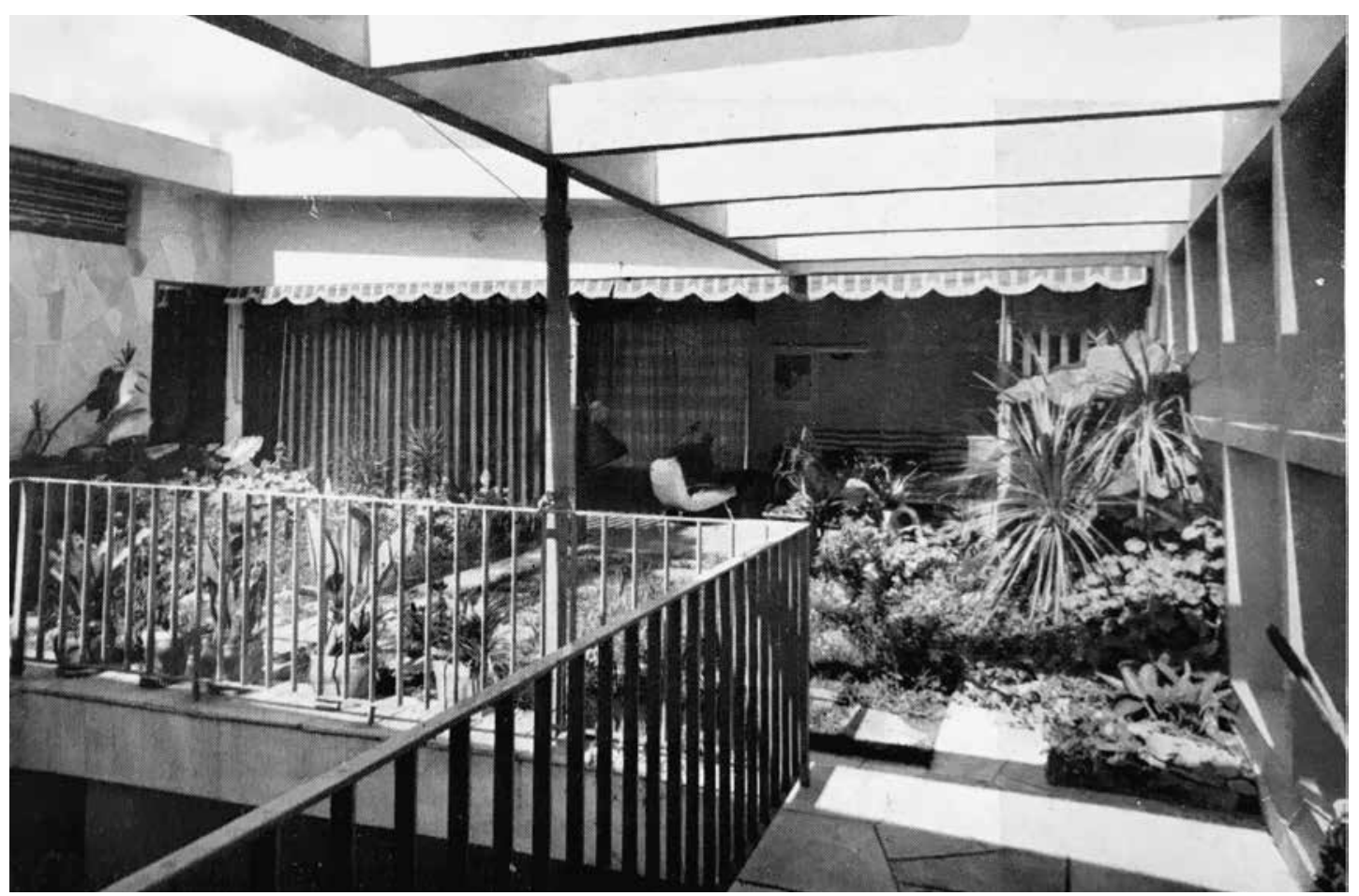

Figura 13. Jardim para residência Guilherme Hannud, projeto de Saia. Fonte: Acrópole, 1956, p. 178

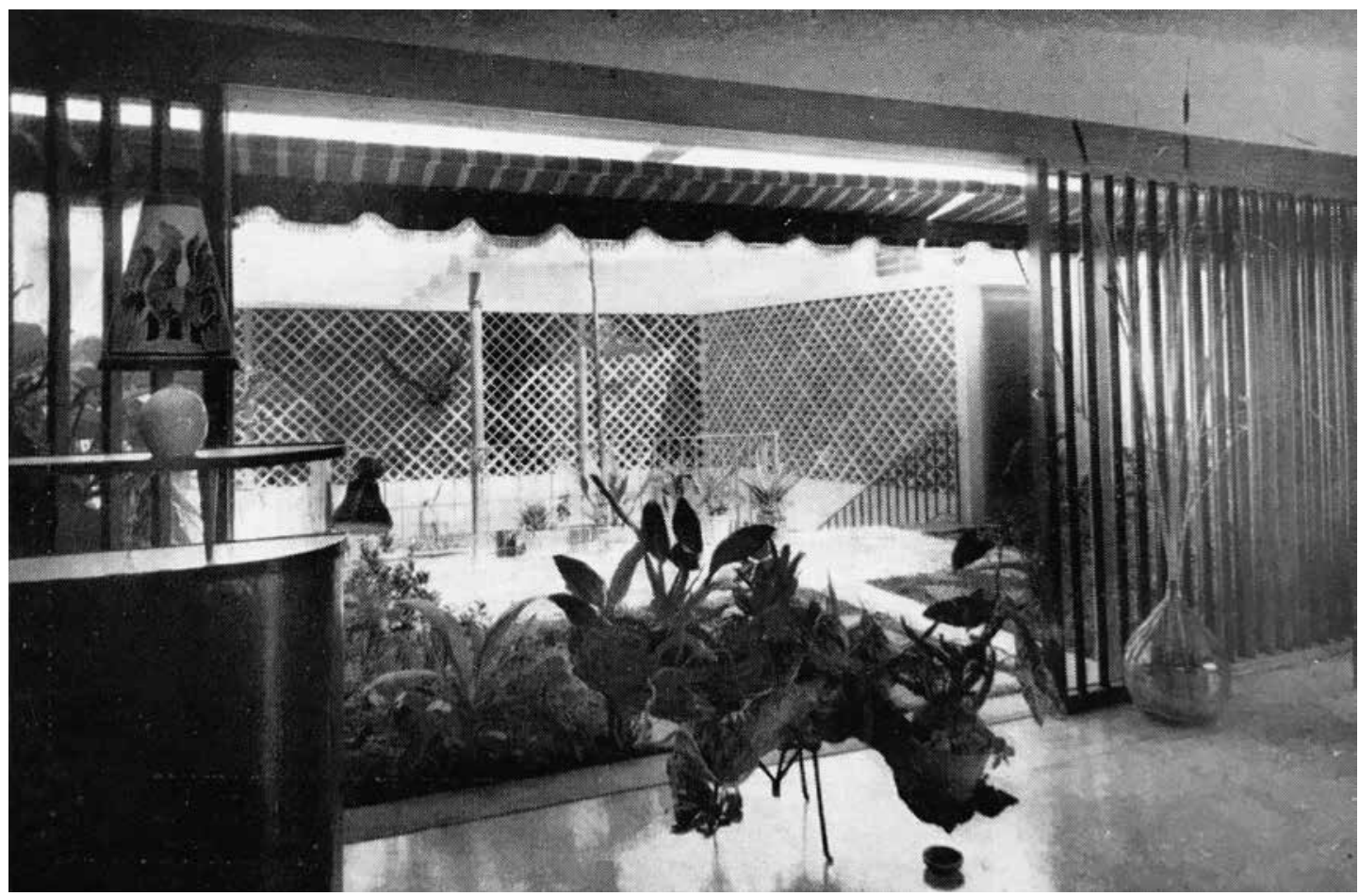

Figura 14. Jardim para residência Guilherme Hannud, projeto de Saia. Fonte: Acrópole, 1956, p. 178 
local, que era um estábulo, montou o escritório de decoração e projetos paisagísticos, além de executar pequenos ornamentos florais com folhas secas e vasos cerâmicos, que eram vendidos em uma loja na Rua Augusta, na cidade de São Paulo, com o inusitado nome "Zanini”. (MELO, 2001, p. 54) 


\section{primeira ida a Brasília}

Zanine continuou a trabalhar com plantas assim que se mudou para Brasília, um pouco antes da inauguração da cidade. De acordo com Chaim, ele "comprou uma chácara próxima à atual região administrativa de Santo Antônio do Descoberto, onde cultivava mudas de espatódia, flamboyant, sibipiruna, ipê e diversas outras plantas nativas"(CHAIM, 2017, p. 37). E foi nesse momento que começou a montar os famosos arranjos decorativos com as flores do cerrado, que se transformaram numa tradição na cidade até os dias atuais.

Em 1962, Zanine foi chamado por Darcy Ribeiro para organizar a Universidade de Brasília e formar, nas palavras do antropólogo, "gente capaz de usar as mãos":

\footnotetext{
Ao pensar a Universidade de Brasília, queria um centro de ensino diferente. Por isso procurei incorporar Zanine a ela, como um professor daquilo que era tão precioso como, digamos, a estética de Niemeyer: o ensinamento de usar as mãos, levar arquitetos a serem capazes de usá-las. E o Zanine foi realmente extraordinário nisso. De um lado, ele ensinava o uso das mãos e, do outro, percorria criticamente as cidades ao redor de Brasília, estudando soluções arquitetônicas, revisando uma tradição popular brasileira. Lembro que Brasilia não foi feita no deserto, como pensa muito idiota. Há cidades que são de 1720. E todo o trabalho de Zanine com os alunos, além de lhes ensinar como fazer maquetes, era percorrer tais cidades, levando-os a desenhar as formas encontradas, preservando uma tradição arquitetônica da região. (RIBEIRO, apud SILVA, 1988. Não paginado).

$\mathrm{O}$ arquiteto Cydno Silveira, aluno da primeira turma de arquitetura da UnB, descreveu como eram as aulas ministradas po Zanine. Segundo ele, no primeiro semestre, como o galpão de marcenaria ainda não tinha sido construído, Zanine deu um exercício que era esculpir um operário na pedra sabão. Zanine levava a escultura de um operário e a deixava em cima da mesa. Entregava um pedaço de pedra sabão para cada estudante, que devia esculpir o busto do operário (f.15 e f.16):
} 
Esse foi o primeiro semestre dele, porque ainda não tinha a oficina. As construções eram muito rápidas na época. Pra mim aquilo era natural, mas não eram e hoje em dia eu vejo aquilo, nossa, como se fazia rápido um galpão. Eu sei que meses depois o Zanine já estava com o galpão e com máquina lá dentro. Ai o primeiro exercício foi o banco e, logo depois, as maquetes. As aulas dele eram o seguinte, as primeiras. Ele tinha aquelas máquinas todas dentro de uma oficina e nós tínhamos que trabalhar. Ele dizia, vocês vão fazer um banco. Nós começamos com um banco. A gente pensa que banco é fácil? Ai que a gente comecou a entender a arquitetura também. $O$ travamento, o encaixe de cada banco, como era, como tinha que ser. Ia mexer! Aquilo tem um esforço. Móvel é uma arte fantástica, e você tem que botar em uso, que épara testar. E aí nós fizemos um banco que era simples a principio. Depois disso foram as aulas de maquete. A aula de maquete. Nós já estávamos aprendendo arquitetura, as aulas de maquete foram dadas pelo Zanine. Você tinha o seu projeto. O Zanine nem perguntava se você tinha planta. Você tinha que fazer o seu projeto lá. A apresentação final do nosso projeto era com a maquete e com a planta. $O$ Zanine, a principal coisa que ele me deu, não foram os encaixes, mas ver os esforços como eles são, como eles agem, como você vai combater. E foi isso o que ele me ensinou, como é uma planta, uma samambaia, como ela se estrutura. Como se estrutura uma folha. Por que a folha tem essa linha? Foi muito simples. O principal é você saber como se comporta uma estrutura. Para isso ele usava muito a mão. (SILVEIRA, entrevista de 09/11/2017)

No período em que ficou em Brasília fez suas primeiras casas em madeira, embora ainda com muita alvenaria na estrutura de sustentação da cobertura:

Na nova capital ele chegou a construir algumas casas, mas reconhecia que o ponto de partida da sua trajetória de arquiteto da madeira se deu em seguida: "eu tinha me transferido de Brasilia para o Rio. Lá já havia feito algumas casas de madeira, mas a sistemática veio aqui com as casas da Joatinga. Aprendi muito com os operários e os mestres de obras. (SEGAWA, 2003, p.12)

De acordo com Chaim (2017), a primeira residência de Zanine em Brasília foi a Residência Cunha Campos. Esta (f.17) provavelmente foi a primeira residência em madeira projetada por ele. Inicialmente feita para ele mesmo, conforme documentos encontrados por Chaim:

Os documentos identificados na Administração Regional do Lago Norte estão em nome de Delza da Silveira Dórea, primeira proprietária da residência e esposa de Zanine Caldas à época, o que comprova as informações coletadas em entrevista com o proprietário atual, de que o arquiteto e sua familia moraram na residência. À época professor demitido da Universidade de Brasilia, devido ao Golpe Militar de 1964, Zanine precisava vender às pressas a residência onde morava com sua familia para sair de Brasília. Sem antes conhecer o arquiteto, o Senhor Cunba Campos buscava um local afastado, que lembrasse as fazendas de Minas Gerias, sua terra natal, que tivesse acesso ao Lago Paranoá e onde pudesse aproveitar com a familia durante os fins de semana. (CHAIM, 2017, p. 72) 

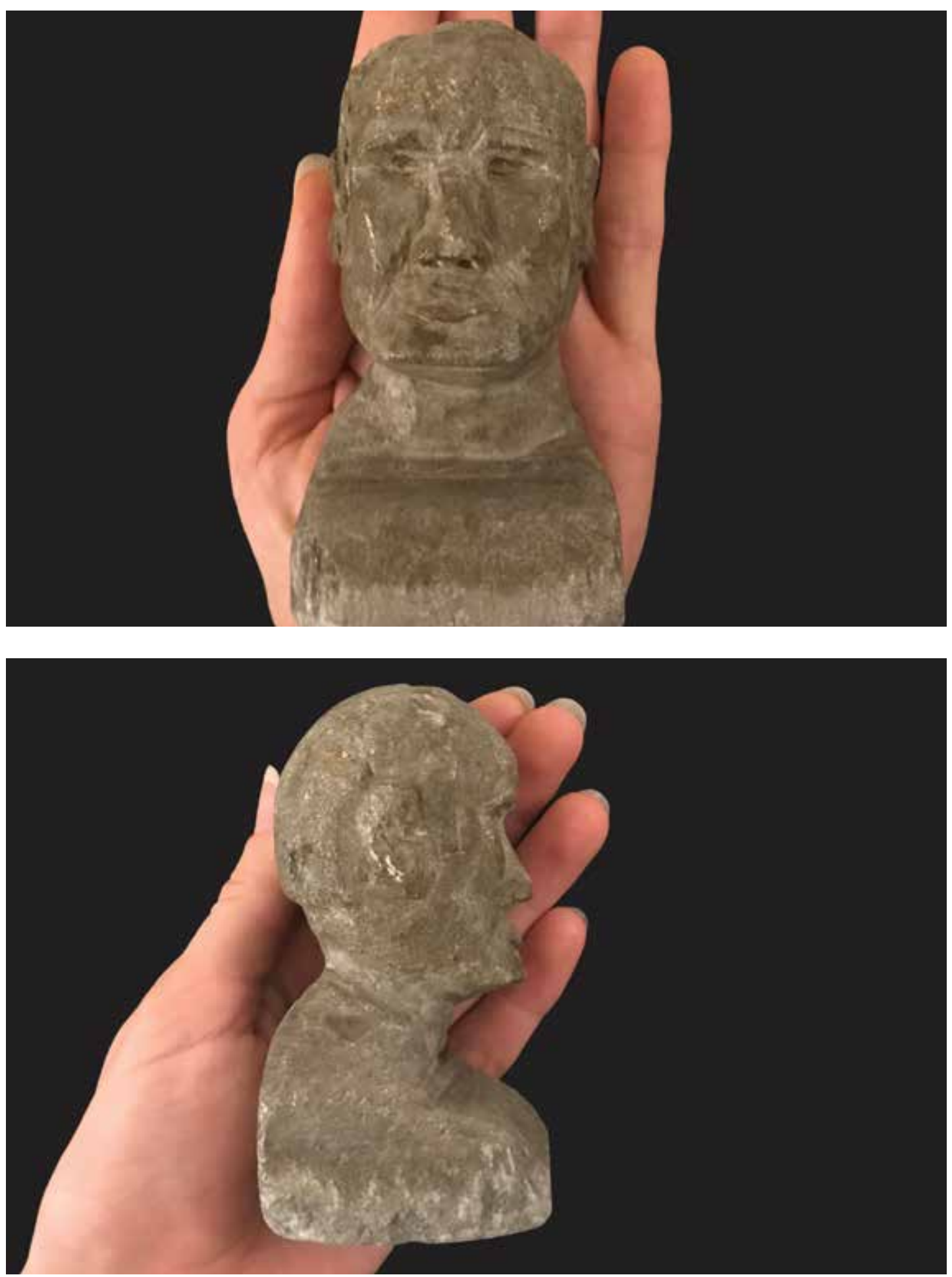

Figuras 15 e 16. Operário esculpido por Cydno Silveira em pedra sabão em aula da UnB, sob orientação de Zanine. Fonte: Amanda Carvalho. 
É interessante pensar o que era Brasília em 1960. Uma cidade recém construída, um sonho concretizado, mostrando para o mundo que é possível construir a capital de um país em 3 anos. E, para habitar essa cidade, foi preciso trazer trabalhadores qualificados de todas as partes do país.

Muitos jovens se mudaram para Brasília, acreditando na possibilidade de um país diferente; deixaram o conforto de cidades já equipadas, assim como a companhia da família e amigos de longa data. Tỉnham em comum a crença de que Brasília poderia significar a criação de uma cidade mais humana e igualitária. Esses habitantes criaram um forte vínculo de amizade.

E é dessa época a amizade de Zanine com o casal Dr. Sávio Pereira Lima e Sylvia Orthof, que se mudou para Brasília em 1960, após morar em Nova Viçosa, onde o Dr. Sávio foi médico da grande madeireira Elecunha ${ }^{10}$. Eles tinham uma filha, que escreveu o texto abaixo, permeado de lembranças e memórias da infância, a partir da qual entendemos a relação de amizade entre o casal Zanine e Delza (no texto chamada de Tia Deusa) e seus pais:

Meu Tio era muito criativo, um gênio da criatividade, mas ninguém sabia o que passava na cabeça dele. Fechado. Duro e seco como um severino nordestino. Fechado. Comunista. Trabalhava escondido. Inventava e vendia seus inventos para a burguesia que desprezava. Depois ficou rico fazendo casas numa montanha do Rio de Janeiro com a pirambeira e o mar lá embaixo. Virou arquiteto sem nunca ter sido. Receben o aval do Grande-Arquiteto-Pai-de-Todos. Fez. muitas casas onde nunca ninguém tinha ido. Ele só gostava de desbravar, de ser pioneiro, de ir antes dos outros e isto unia aqueles amigos a quem nós chamávamos de tios porque em Brasilia ninguém tinha família nem vô, nem vó, nem tio, nem tia. Foi ele que criou as flores secas de Brasília que hoje são vendidas em todas as lojas de turistas da capital. Essas flores não existem na natureza, são a mistura de coisas encontradas no cerrado, que ele espetou uma na outra e vendia nuns arranjos de casca de árvore do cerrado na floricultura da Tia deusa. (fonte pessoal ${ }^{11}$ )

Acredita-se que foi essa união entre Zanine e Dr. Sávio que fez com que Zanine conhecesse e se interessasse pela cidade de Nova Viçosa. E ainda, de acordo com depoimento da Claudia Orthof, filha do Dr. Sávio, Zanine viajava sempre pelas pequenas cidades do arredor de Brasília, para pegar móveis antigos e revender na nova capital.

Numa das viagens pelo interior, Zanine trouxe uma cama e a doou para Claudia quando ela ainda era pequena. Numa história sobre a cama e sobre Zanine e Delza, Claudia transmite um pouco das sensações do que foi esse período em Brasília:

10 Uma grande madeireira localizada em Nova Viçosa, sul da Babia.

11 ORTHOF, Claudia. Minha caminha. Texto recebido por esta pesquisadora via correio eletrônico, no dia $07 / 11 / 2017$. 


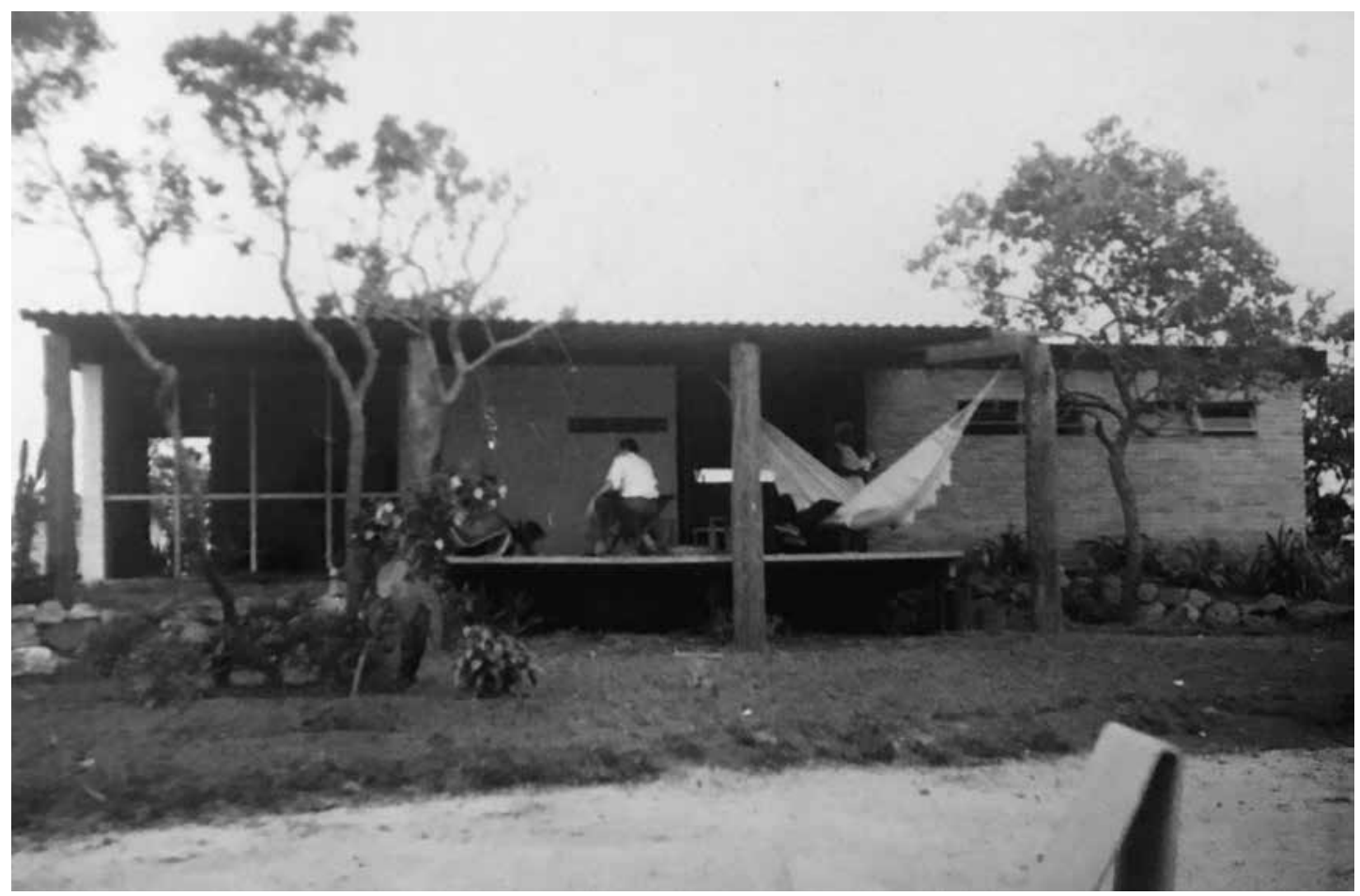

Figura 17. Primeira casa projetada por Zanine em Brasília. Fonte: Acervo pessoal de Déa de Zanine.

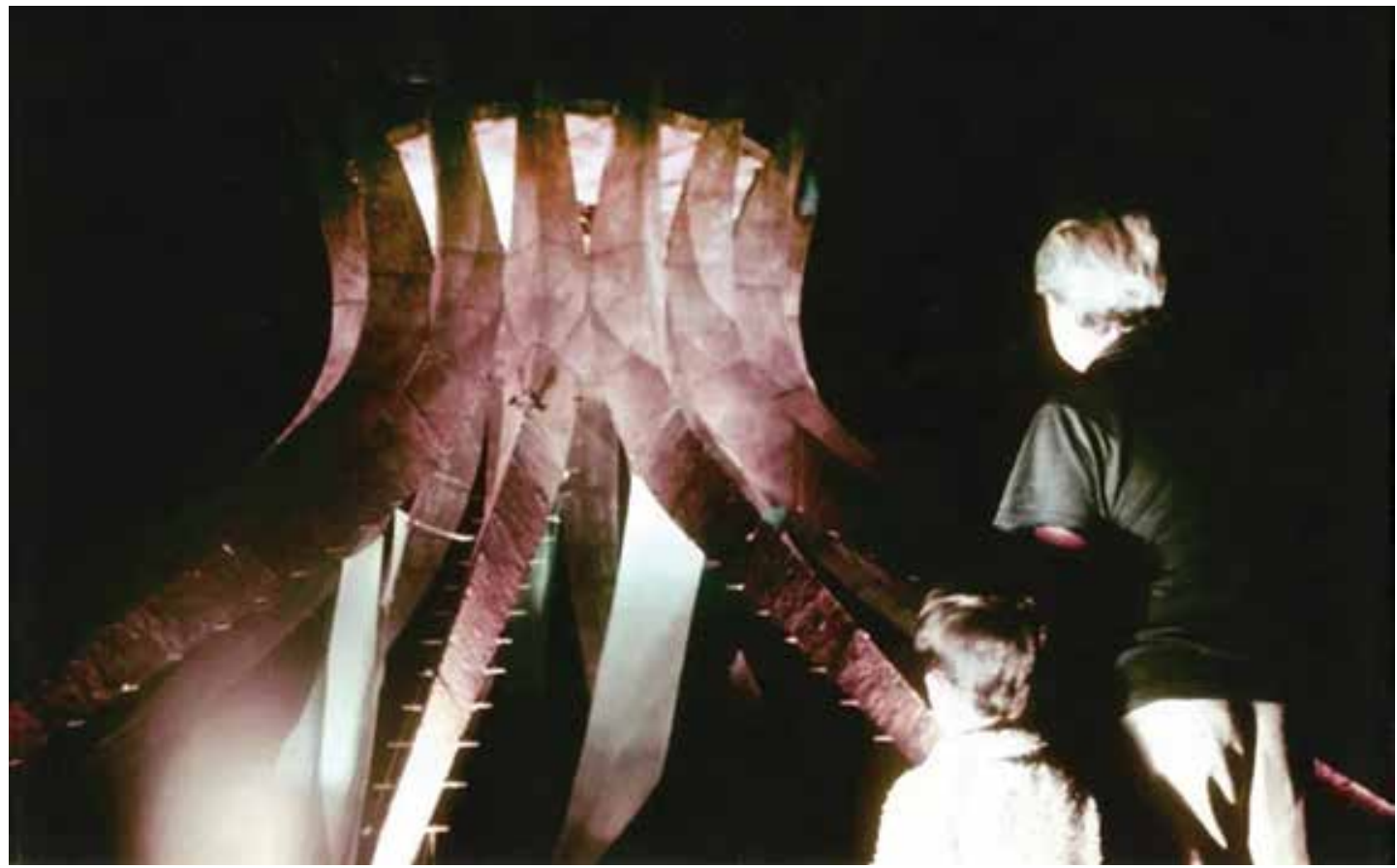

Figura 18. Dr. Sávio e seu filho em Brasilia no início da década de 1960. Fonte: acervo pessoal de Claudia Orthof. 
Figura 19. Construção de

Brasilia. Fonte: site Archdaily,

fotografia de MarcelGautherot.

Um dia eu estava dormindo na minha-caminha de madeira cheirosa e lisinha que eu passava a mão e sabia que estava segura porque era lá que era a minha casa, meu Papai, minha Mamãe e meus Irmãos. Alguém me pegou no colo e me deitou num colchão que estava arrumado com lençol no chão. Eu tentei abrir o olho mas meu Pai susurrou dorme filha dorme gostosinho que a tua Tia deusa vai dormir hoje na tua cama. Acordei de novo depois e minha Tia deusa estava deitada de lado com sua calca de brim aberta e a barriga crescida. Seus olhos tristes estavam molhados e eu sabia que não adiantava perguntar. Ela não ia responder, só calar. Eu conhecia aquelas regras. Tinha o olhar de cala-a-boca-meu-bem. Dormi de novo. Acordei com alguém me pegando no colo. Só que não era meu Pai. Tinha peitos. Era mulher mas não era minha Mãe. Era minha Tia deusa que me colocava de novo na minha-caminha-de-quando-eu-eramenininha. Eu quis acordar mas ela disse susurrando dorme de novo, neguinha, na tua caminha que teu Tio te deu, querida, dorme e sonha com ele livre aqui de novo com a gente prá ver a filha dele nascer, sonba, neguinha, que sonbo de criança é poderoso e faz as coisas acontecerem, ai minha mãe, minha mäinha, me ajuda... Naquele tempo muitas vežes nossos pais choravam um choro calado que já tínhamos aprendido que era assunto de adulto. Às vezes eles cantavam emocionados músicas que só podíamos cantar quando eles começavam. Só quando determinadas pessoas estavam juntas podiamos cantar. Sópessoas de confiança. Mas às vezes eu achava que alguém era de confiança e já não era mais. Escutava os adultos discutindo se era ou não era X9, dedo-duro. Gente que se infiltrava no teatro de estudantes da minha Mãe mas não aparecia na universidade. Era difícil entender. O jeito era ficar quieta e olhar muito e deixar os olhos jabuticabas procurarem a resposta. A gente adoecia, garganta inflamada, operação de amigdalas, asma de sufoco sem explicação... Não adiantava perguntar. Era 1964. Tempos de golpe militar. Meu Tio cangaceiro sumiu e minha Tia deusa ficou chorando com sua barriga crescendo e ela abrindo o fecho da calsa e amarrando com um barbante. Tirando espinho de rosa. Vendendo flores do cerrado. (fonte pessoal ${ }^{12}$ )

Com o golpe de 1964, que deporia o presidente João Goulart (1961-1964) e instauraria a ditadura civil-militar que perduraria no Brasil por mais vinte anos, Zanine e mais um grupo de professores seriam cassados e teriam de se afastar das suas funções na universidade.

Zanine foi um dos primeiros professores a ser preso pois, apesar de não participar mais, ainda era filiado ao Partido Comunista e havia se esquecido de dar baixa no registro. Ele recebeu asilo no consulado da Iugoslávia no Brasil. Nesse momento, segundo depoimento de sua filha Déa de Zanine (conhecida como Cuca), sua mãe Delza estava grávida e não quis se mudar para outro país, fazendo com que planejassem uma fuga do consulado.

12 ORTHOF, Claudia. Minha caminha. Texto recebido por esta pesquisadora via correio eletrônico, no dia 07/11/2017. 


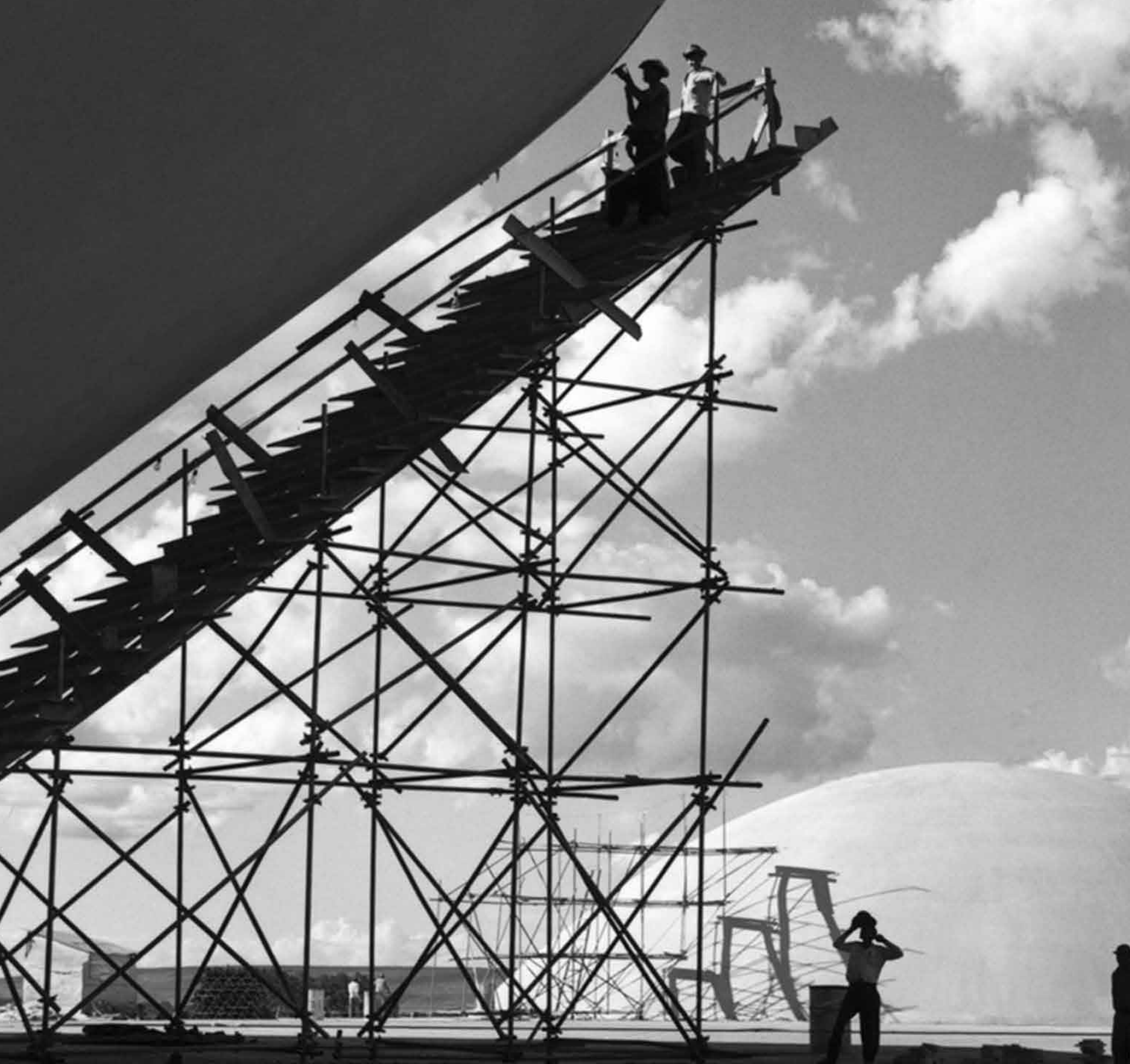




\section{casas da Joatinga}

Zanine chegou ao Rio de Janeiro em 1964 com uma esposa, uma filha no colo e sem dinheiro. Segundo Déa de Zanine, sua filha, em entrevista realizada em 08 de novembro de 2017, chegaram em Ipanema, onde moraram na Rua Prudente de Moraes. Mudaramse para Joatinga, na Barra da Tijuca, aproximadamente em 1967.

É interessante notar que antes da construção das casas em madeira da Joatinga, com as quais se tornou conhecido, Zanine já carregava consigo o conhecimento da construção das casas de madeira e terra de Belmonte, o que, somado às viagens que fez com os estudantes da UnB, observando a arquitetura vernacular do arredor de Brasília, e ao trabalho que executou junto ao Serviço do Patrimônio Histórico e Artístico Nacional (SPHAN), permitiu que conhecesse as casas tradicionais do Brasil.

Para ele, muito mais do que pensar somente na modernidade, tínhamos de analisar que "o que aprendemos nas ruas e nos interiores das nossas cidades históricas é uma linha de coerência com o trópico a ser continuada e aperfeiçoada no século XXI" (CALDAS apud SILVA, 1988. Não paginado). Esse pensamento aproximou-o de um discurso diferente do hegemônico na arquitetura brasileira até aquele momento, caracterizado pela afirmação do concreto armado como principal elemento das construções.

Segundo Déa, entre 1968 e 1969 Zanine e Delza viajaram pelos países da África e Ásia, observando a arquitetura e os costumes dos mesmos:

Viajei para a China. Um povo realista. É muito diferente o modo como se pode fazer coisas tão geniais. Olhei mil vezes os beirais chamados "de cachorro" chineses que os portugueses trouxeram para as casas coloniais do Brasil. Ai está o segredo das culturas humanas: as coisas, os objetos, os atos, são essencialmente os mesmos, repetidos de formas diferentes em cenários naturais diversos. A bumanidade é uma coisa só. (CALDAS apud SILVA, 1988. Não paginado)

Essa viagem, feita no início das construções das casas da Joatinga, trouxe referências que se somaram às experiências construtivas tradicionais e modernistas brasileiras, ampliando o repertório projetual do arquiteto e dando às suas obras características únicas. Zanine sabia olhar para o popular, para o vernacular, muitos o 


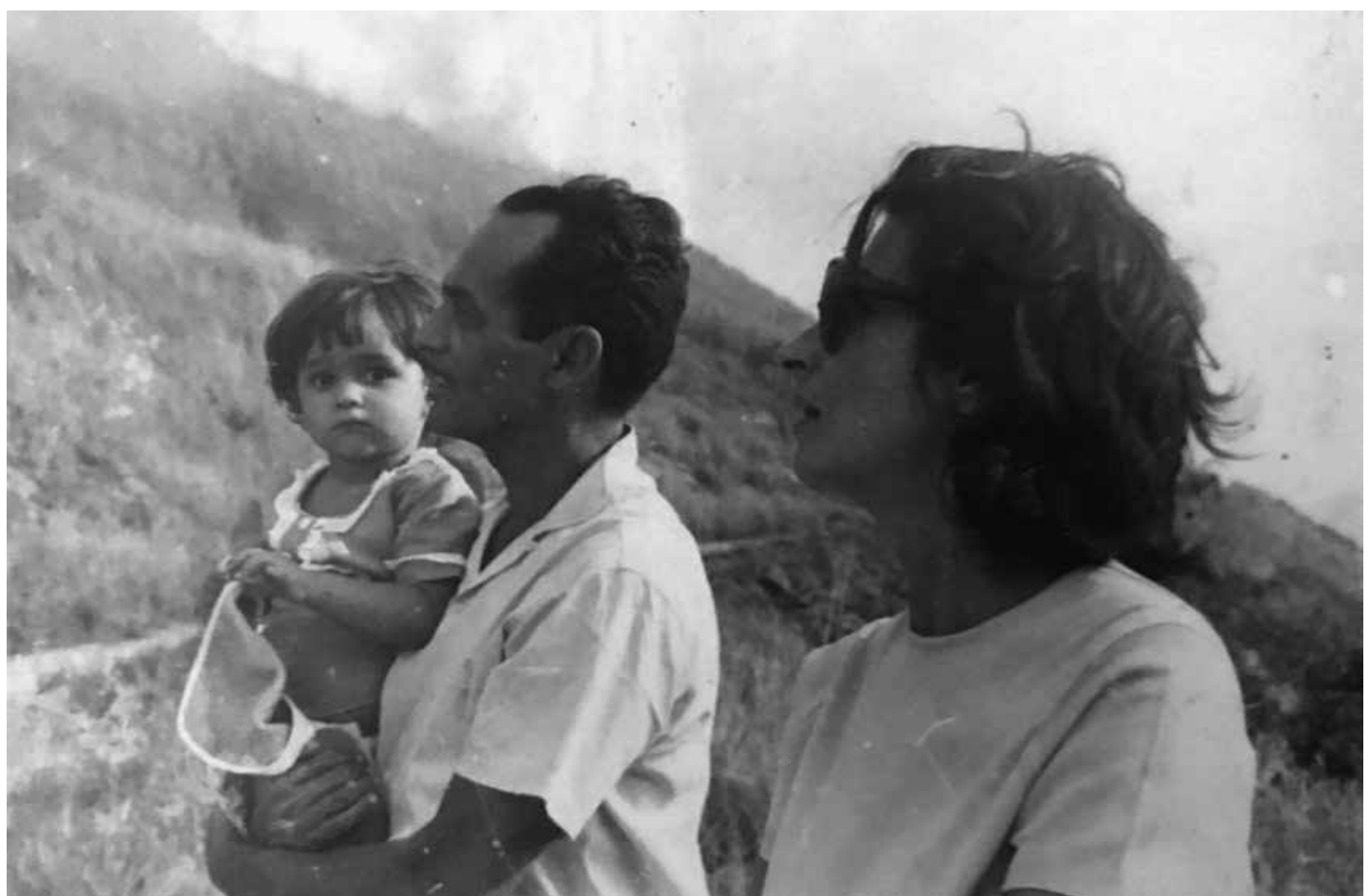

Figura 20. Zanine com Déa no colo e Delza. Fonte: acervo pessoal de Déa de Zanine.

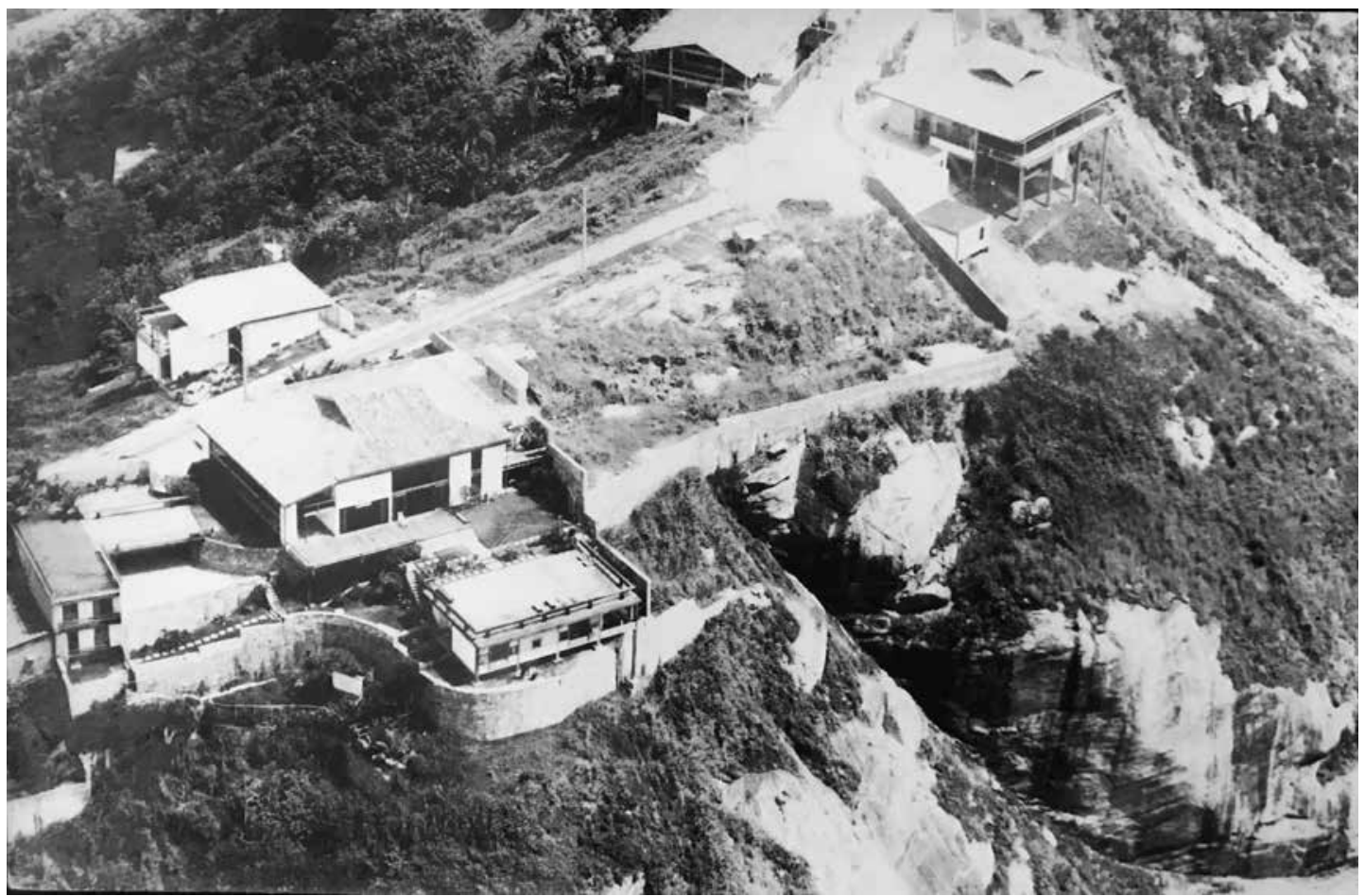

Figura 21. Construcões na Joatinga. Fonte: acervo pessoal de Déa de Zanine. 
descrevem como curioso. Ele soube ver a arquitetura em diversas épocas e culturas, aproveitando o potencial de cada uma delas, aplicando-o nos seus projetos.

Esse olhar para a tradição também era notado na escolha de profissionais para trabalharem com ele, segundo Chaim:

Zanine buscava no interior do estado aprendizes de carpinteiros e marceneiros que soubessem trabalhar de acordo com as tradições construtivas da região. Em Petrópolis, encontrou mestres-de-obra que exerciam o saber tradicional da construção em madeira herdado da imigração alemã, com quem contou fielmente nas décadas que se seguiram: Reduzino Vieira, responsável pela construção da maioria das casas da Joatinga, e José Araújo, executor das casas de Brasília. (CHAIM, 2017, p. 43)

Todas estas referências fizeram com que Zanine construísse casas (f.21, f.22, f.23, f.24 e f.25) bem diferentes das que estavam nas revistas daquele momento. Começandose pelo material: em vez de concreto, usou a madeira. $\mathrm{O}$ teto era de telha de barro, material comum, mas, diferentemente das casas tradicionais do Brasil, usou grandes painéis de vidro, incorporou a paisagem às suas casas e elevou-as do terreno, não como os pilotis modernos, que liberam o piso para outros usos, mas para pousar a casa sobre o terreno sem efetuar grandes mudanças no mesmo.

Essas casas recuperavam o saber-fazer tradicional e suas técnicas, tão bem observadas por Zanine durante sua infância, somando a elas a visão espacial adquirida por ele na convivência com os arquitetos modernos. E é a soma desses conhecimentos que faz dessas casas tão únicas. Um arquiteto formado numa escola determinada de arquitetura dificilmente teria esse olhar para o vernacular, incorporando-o à sua prática projetual, assim como um construtor nascido em Belmonte dificilmente questionaria a técnica usada até então, experimentando-a para saber quais seriam seus limites e como superá-los. Para isso era preciso uma pessoa que olhasse o vernacular com os olhos livres de pré-conceitos, uma pessoa capaz de entender o potencial desta técnica mas que também não a mantivesse no seu estado atual; uma pessoa que através de questionamentos vislumbrasse novos usos, resultando em novas formas.

O percurso que levou Zanine a construir as famosas casas da Joatinga começou, segundo Ivan do Valle ${ }^{13}$, com a compra de um terreno grande perto da Pedra da Gávea, não na Joatinga, mas no começo da Barra da Tijuca, numa área que era alagada.

Nessa época o Rio de Janeiro estava em plena reforma, demolindo as casas do centro, em parte para a construção da perimetral, que começara na década de 1950, em parte para construção da linha do metrô, que começara no final da década de 1960. Havia escadas helicoidais, janelas, portas, guarda-corpo de escadas, tudo sendo jogado fora. Segundo Vivacqua:

13 Professor da UnB e pesquisador da obra de Zanine, trabalhou com o designer-arquiteto nas décadas de 1980 e 1990. 

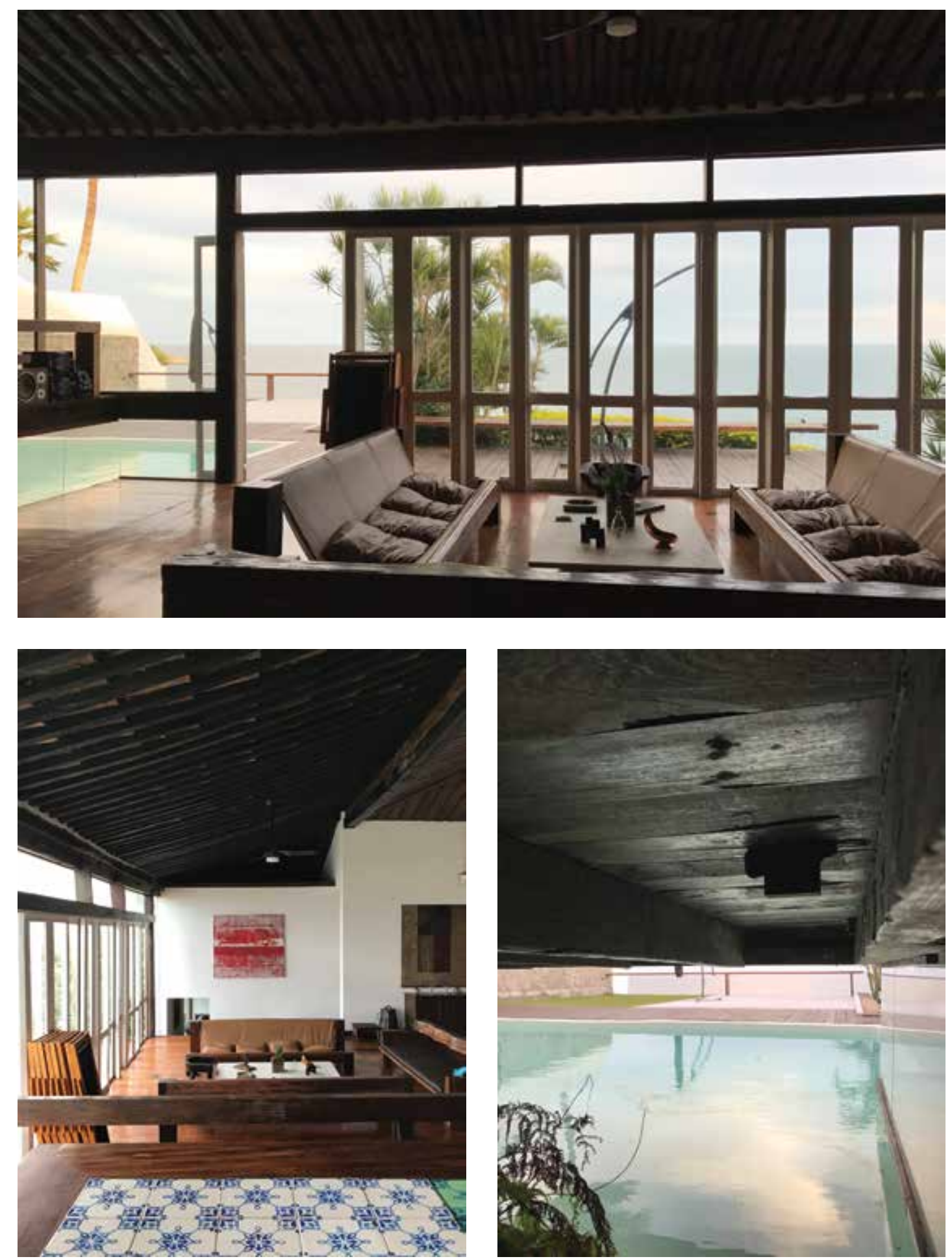

Figuras 22, 23 e 24. Fotos da primeira casa feita por Zanine no morro da Joatinga. Abaixo e à direita, detalhe de como Zanine prendia os móveis à estrutura da casa. Fonte: Amanda Carvalho. 
Figura 25. Fachada da primeira casa feita por Zanine na Joatinga. Interessante ver como ela se apoia sobre a pedra. Fonte: Amanda Carvalho.

Reagindo a isso, alguns artistas, como Zanine e Burle Marx, comecariam a trabalhar pioneiramente com parte do material que restara do contínuo processo de demolição do casario histórico das regiões centrais do Rio. Ao se apropriarem e reaproveitarem pilares, vigas, assoalhos, detalbes de janelas e portas, soleiras e batentes frutos das demoliçoes, de certa maneira, realizavam também uma denúncia das abruptas e violentas ações do governo militar, não apenas em direção ao patrimônio histórico e à memória da cidade, mas a todas aquelas violações de direitos democráticos que se realizavam dentro de um regime de exceção. (VIVACQUA, 2013, p. 44)

Zanine faria suas famosas casas reaproveitando nelas integralmente a madeira de lei que era descartada nessa série de demolições. Sobre essa apropriação, ao descrever a sua impressão sobre duas casas que visitara de Zanine na Joatinga, Lucio Costa destaca no trabalho do arquiteto:

.... a particularidade de utilizar (...) materiais de construção já vividos - madeirame, tijolos, telhas, serralheria - de casas demolidas, matérias que já haviam sido estruturados em "aconchegados ambientes", portanto, participado do dia a dia e da intimidade de pessoas já sumidas, mas que, desarticulados da coesão arquitetônica que os unira por tantos anos jażiam inertes entulhando depósitos de "material de demolição", até que, um dia, a sensibilidade e o engenho de um Zanine os recolhessem e reestruturassem, criando com eles, como que rejuvenescidos, ambientações diferentes daquelas a que estiveram de início afeiçoados. (COSTA, 1995, p. 443)

No mesmo momento, eram lançados terrenos na praia da Joatinga, na Zona Oeste da cidade do Rio de Janeiro. Esses terrenos tinham uma inclinação acentuada, dificultando as vendas dos mesmos e desvalorizando-os economicamente. Segundo Ivan do Valle,

o Zanine começou a comprar um terreno lá e construiu. Fez aquela casa bonita, que era onde os artistas iam se encontrar, Tom Jobim, Vinícius. Eles iam se encontrar na casa do Zanine. O Zanine era o cara, o amigo de todos, eles iam se encontrar lá, compor música, tocar violão, beber, enfim, bater papo de modo geral. E aí começou essa roda de artistas e intelectuais, conhecendo a obra dele, o próprio Lúcio Costa, o Sérgio Rodrigues. Ele ficou muito conhecido fazendo essa arquitetura na Joatinga. Com os preços baixos do material, ele começou a ganhar dinheiro, foi comprando lotes e construindo as casas. O Reduzino falou pra gente que ele combinou ou comprou um local lá na Joatinga, onde fez. um depósito de materiais de demolição, pra uso dele. Então ele ia faz̧endo a casa e aproveitando: pega aquela janela, pega aquela porta, pega essa escada, pega esse guarda-corpo, essa madeira aqui de demolição, corta ela. E foi assim que ele começou ali no Rio de janeiro. E ai, lógico, comprava uma peça ou outra, mas aproveitava muito (VALLE, entrevista concedida à pesquisadora, 09/06/2016).

Antes, as pessoas pagavam para retirar o entulho do terreno, Zanine retirava o material, que adquiria de graça, e o usava nas suas casas. Do terreno, que muitos 


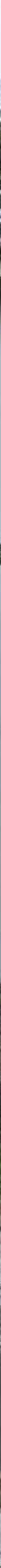


consideravam ruim, ele soube aproveitar a inclinação e fez um edifício que pousava sobre o mar. Com grandes cortinas de vidro, trouxe a beleza do Rio de Janeiro para dentro das casas e ainda economizou duas vezes - a primeira no terreno e a segunda por reaproveitar os materiais de demolição. Além disso, recuperou o trabalho artesanal de mestres de obras ao utilizar portas, grades, escadas e outras peças em diversas habitações.

As encarapitadas casas de Zanine em Joatinga e em outras partes do Rio de Janeiro exploravam os panoramas que dali se descortinavam. A habilidosa combinação de madeiras, vidro, alvenarias e material de demolição, conferia um toque artesanal, pessoal e sofisticado para as moradias. (SEGAWA, 2003, p. 13)

Figura múltipla, arquiteto-designer, é interessante notar que Zanine projetava os móveis como parte da estrutura da casa - da mesma maneira como os arquitetos modernos faziam o mobiliário de concreto fixo. Fica claro um pensamento de casa que extrapola os limites estruturais, e a concepção espacial, indo até o espaço do sentar, posicionando o sofá no melhor ângulo para se observar a natureza. Zanine pensava a casa como um todo, em todos os detalhes, fato que apenas um grande conhecedor do saber-fazer e um espírito que busca na residência a emoção e o acolhimento conseguiria projetar e executar.

Tecnicamente, ele conhecia os encaixes e a escala do desenho industrial. Para quem conhece esses segredos e é apaixonado pela transformação da matéria em objetos, nada mais natural do que projetar cada detalhe da casa.

A implantação da mesma era muito bem pensada, sempre vinculada às potencialidades naturais do lugar. Uma das características do arquiteto é a de não mexer na topografia do terreno, deixando pedras na sala, caso elas já existissem no local. Os painéis de vidro eram usados definindo os pontos da paisagem que seriam vistos.

Segundo depoimento de Katinsky, na revista Arc Design:

Essas casas revelavam uma familiaridade com técnica de materiais tradicionais, usando paredes de tijolo revestido de argamassa, cal e areia, muitas vezes apoiadas em estruturas em "gaiola" com grossas traves de madeira, "importadas" de 2 mil ou mais quilômetros, vindas das florestas brasileiras à planicie amazônica. Havia uma casa, que ele havia feito para sua moradia, que lembrava, no dizer de mens colegas cariocas, a casa colonial paulista. E, de fato, via-se uma interpretação livre da casa do sitio do Padre Ignácio, que Luís Saia havia restaurando nos anos 50. Zanine fizera a sua em 1978, muitos anos depois de haver visto essa casa, que ele provavelmente guardou na memória, com seus dois volumes luminosos brancos associados pelo vazio da varanda, negro na casa de Zanine pelo pano de vidro Blindex. (KATINSKY, 1999, p. 52 e 53)

As casas da Joatinga eram feitas no canteiro de obras, contavam com diversos 
profissionais habilidosos no manuseio da madeira. Segundo Reduzino ${ }^{14}$, muitos dos detalhes eram definidos no próprio canteiro.

Em 1968, Zanine foi para Nova Viçosa, na Bahia, a convite do seu amigo Dr. Sávio. Essa época será melhor detalhada no próximo capítulo, dedicado à Nova Viçosa, mas, para termos uma ideia do desenvolvimento da obra do Arquiteto, falaremos brevemente sobre o período.

Em Nova Viçosa, Zanine fez o projeto de uma cidade ecológica respeitando a natureza e o saber-fazer local. $\mathrm{Na}$ região acontecia um grande desflorestamento e havia muitos troncos de árvores mortas e raízes destocadas que seriam queimadas. Com essa madeira Zanine criou os "móveis-denúncia” e, em conjunto com os construtores de canoas, fez uma série de móveis que mantinham o formato da árvore, com o intuito de denunciar o desrespeito às florestas.

Também fez estruturas para casas, que foram chamadas de "pré-elaboradas". Eram de madeira, cubos no espaço, montados e numerados para serem desmontados e enviados para todo o Brasil.

Não se sabe exatamente os motivos que levaram Zanine, em 1980, a sair de Nova Viçosa, mas de acordo com depoimentos, provavelmente foi a decepção de não conseguir levar adiante seu projeto urbanístico e sua ideia de transformar a cidade em um grande polo artístico.

14 Carpinteiro que trabalhou com o Zanine a partir da construção das casas da Joatinga. Entrevista concedida à pesquisadora em 04.05.2017. 


\section{segunda ida a Brasília}

Zanine chegou pela segunda vez em Brasília no início da década de 1980, onde exerceu diversas atividades. Entre elas, destacamos: construção de casas, retorno à UnB e continuidade dos trabalhos do Centro de Desenvolvimento das Aplicações das Madeiras do Brasil (Fundação DAM), idealizado por ele em 1983, no Rio de Janeiro, e que tinha como proposta a pesquisa do uso e aplicação das madeiras no Brasil.

As casas projetadas por ele no DAM tinham suas estruturas feitas numa carpintaria e montadas no canteiro, com o auxílio de bons carpinteiros. Essa forma de trabalho remete ao período de Nova Viçosa, em que as estruturas das casas eram feitas na sua oficina e enviadas para todo o Brasil, onde eram montadas nos terrenos definitivos.

O livro Taipa em Painéis Modulados (1988), desenvolvido pelo DAM, é uma cartilha descritiva e ilustrativa que ensina qualquer pessoa a fazer casas com estrutura de madeira e vedação de taipa. Ele é o resultado de uma série de projetos alternativos desenvolvidos na região Nordeste e Norte do Brasil para promover a reconstrução das casas que foram destruídas por uma grande enchente em $1985^{15}$.

O princípio básico da metodologia de trabalho partia do saber-fazer local e da utilização de matérias-primas naturais já empregadas pela população. A partir disso, propuseram seis projetos distintos, fundamentados no processo de autoconstrução familiar.

Esses projetos incorporam na sua concepção o legado da tradição e o impulso da modernidade, através do resgate da técnica da taipa, preservando-a e adequando-a às necessidades dos tempos modernos. Também era proposto o uso adequado e racional do potencial madeireiro da região. Para isso foram desenvolvidos painéis modulados que seriam construídos na marcenaria e montados no canteiro. Esses painéis tinham $1 \mathrm{~m} \mathrm{x}$ 2,50m (LxA) e compunham um sistema de alguns tipos (painel cego, painel porta, painel janela baixa, painel janela alta) que podiam ser montados de acordo com o projeto.

A existência de tipologias também traz a ideia de uma continuidade do trabalho desenvolvido em Nova Viçosa, em que Zanine desenvolveu um método de construção

15. Nessa época era comum parte dos habitantes do nordeste perderem suas casas por causa de enchentes causadas por chuvas ocasionais. 
de casas partindo do conhecimento da população local, para que os construtores pudessem fazer as estruturas das casas mesmo sem saberem ler desenho técnico. Para isso, Zanine criou um sistema construtivo de alguns tipos (tipos de pilares e vigas, portas e janelas) e quadriculou o piso da sua fábrica, servindo de medida para construção dos cubos estruturais.

Como método de trabalho habitual de Zanine, faziam maquetes na escala 1:20, com todas as informações do sistema construtivo, pois o projeto arquitetônico nem sempre é compreensível. Segundo Leon:

Em Brasilia pela segunda vez na vida desde 1982, Zanine montou a Escola do Fazer, onde trabalhadores não especializados aprendem o oficio de marceneiros e carpinteiros. Lá foram construidas duas casas, exemplo das muitas que poderiam ter sido erguidas a preços baixíssimos, utilizando a madeira e o barro das regiões onde fossem feitas pela própria população. As empreiteiras não deixaram e as casas-modelo servem a duas familias cujos homens trabalbam na escola. Lá aparecem professores, escultores, artistas populares à busca de lições de madeira. (LEON, 1989, p139)

Em 1989, Zanine mudou-se para França, onde foi correspondente brasileiro do Certificat d'Étude Approfundi “bois", na École d'Árchitecture de Paris Tolbiac, desenvolveu um projeto de cooperação com a Escola de Arquitetura de Grenoble EAG, lecionou na Escola Politécnica de Lausanne, na Suíça, desenvolveu o Centro de Arquitetura da Terra CRATerre, onde, segundo Loschiavo (1992), realizou trabalho sobre o seu método construtivo com a madeira e um projeto piloto de construção de casas populares em madeira e barro.

Participou de diversas exposições, sendo a maior a do Louvre, Paris, chamada L'Architecture et la Forêt (A Arquitetura e a Floresta), que aconteceu entre o final de 1989 e o começo de 1990. Em 1998, mudou-se para o Espírito Santo, onde viveu até 20 de dezembro de 2001. 



\section{capítulo 2 \\ Nova Viçosa}





\section{Nova Viçosa}

Este capítulo será subdividido em: História de Nova Viçosa, Projeto urbanístico, Obras construídas, Móveis-Denúncia e Casas pré-elaboradas.

Conforme depoimento da sua filha Déa ${ }^{1}$, após terminar o projeto do condomínio do Portinho de Massarú, no Itanhangá, Rio de Janeiro, sob encomenda do Márcio Braga, Zanine conseguiu quantidade de dinheiro suficiente para iniciar um novo projeto. Foi quando retornou para o sul da Bahia (informação verbal).

A vontade de retornar ao sul da Bahia foi explicada pelo próprio Zanine durante entrevista no programa do Jô Soares. Quando perguntado se ele chegou a fazer uma cidade, respondeu: "Em Nova Viçosa. Eu nasci em Belmonte e eu fui para fazer alguma coisa, era um pensamento meu, de quando eu cresci: um dia que eu puder fazer alguma coisa eu volto, para ver se eu dou alguma colaboração" (ZANINE, Ser do Arquitetar, 2017)2.

Mas, em vez de retornar a Belmonte, foi para Nova Viçosa. O que o teria feito escolher este destino? Acredita-se que a existência da madeireira Elecunha e de grande quantidade de sobras de madeira, assim como semelhanças geográficas, culturais e históricas entre as cidades de Belmonte e de Nova Viçosa, que fizeram com que Zanine optasse por Nova Viçosa. Uma breve história sobre a cidade mostrará a formação etnográfica e cultural dos seus habitantes, dando-se prioridade ao saber-fazer dos moradores.

1 Informação fornecida por Déa de Zanine em 09.11.2017.

2 Programa Jô Soares onže e meia, do canal de televisão SBT in Zanine: Ser do Arquitetar. 


\section{a história de Nova Viçosa}

Para conhecer a história de Nova Viçosa, três livros foram de fundamental importância: o de Jean Albuquerque, advogada que mora na cidade; o livro de Teodório Cardoso, ex-prefeito da cidade; e o do Príncipe de Wied-Neuwied Maximiliano, que viajou pelo litoral do Brasil entre os anos de 1815 e 1817.

O livro do Príncipe de Wied-Neuwied Maximiliano nos conta suas impressões sobre uma viagem que fez a cavalo, percorrendo o litoral brasileiro. A descrição da sua chegada à cidade de Nova Viçosa é semelhante à descrição que faz da sua chegada a Belmonte, o que nos faz pensar que Zanine sabia que encontraria uma atmosfera parecida com a da sua cidade natal, com diversas pequenas comunidades de artesãos, hábeis no saber-fazer com as mãos. Nas duas cidades encontramos construtores de canoas, artesãos que dominam o trabalho com o enxó, o machado, transformando materiais encontrados na natureza em objetos necessários para o seu dia a dia.

Segundo Albuquerque (2006), em 1720 alguns portugueses vieram de Caravelas, cidade situada a montante do Rio Peruípe e que detinha poder econômico e político nessa região do sul da Bahia, para a Foz do Rio Peruípe, onde já existia uma aldeia indígena. Deu-se início a uma pequena povoação chamada Campinho de Peruípe, futura cidade de Nova Viçosa. Em 1763, após problemas com os donatários da região, a Coroa Portuguesa enviou para o local o primeiro ouvidor, Thomé Couceiro de Abreu.

Somente em 1768 o povoado de Campinho de Peruípe teve autonomia em relação a Caravelas, sendo reconhecido como Vila pelo D. José I, Rei de Portugal. Nessa época, após o falecimento do primeiro ouvidor, a região era dirigida pelo segundo, José Xavier Machado Monteiro, responsável pela Capitania de Porto Seguro, que ia de Belmonte, nas margens do rio Jequitinhonha, a São Mateus, atualmente no Espírito Santo.

Ainda de acordo com Albuquerque (2006), referindo-se ao trabalho do segundo ouvidor no momento da criação da vila: "Como não havia um arquiteto na capitania, ele mesmo, com sua rústica pena, elabora a planta do local, traçando praças, ruas e travessas". Ela ainda descreve como foi a cerimônia de demarcação da Vila Viçosa em 1769 e quais foram os equipamentos usados: 
Devido às fortes chuvas que haviam caido na região, não foi possivel proceder a demarcação do território em outubro de 1768. Em setembro do ano seguinte, por ocasião da nova visita do Ouvidor, José Xavier Machado Monteiro, o arrumador da agulha (bússola) e os ajudantes da corda prestam juramento com as mãos direitas sobre o livro dos santos evangelhos e se comprometem a bem e verdadeiramente arrumar, medir e demarcar pelos rumos a que direitamente pertencer todos os terrenos de terras do termo desta nova vila na forma declarada no termo e auto de criação sem dolo nem malícia alguma. Antes de se iniciar o processo é mostrada ao ouvidor a agulha de marcar e demarcar, com a declaração de que a referida bússola estava preparada para governar a medição. É apresentada, também, a corda que seria utilizada para marcar as distâncias. Ao ser examinada, constata-se ser do tipo que se costumava fabricar na Colônia, chamada de jubira, e o ajudante afirma que havia sido preparada de modo a não espichar ou encolher durante a medição. Saem todos então em comitiva, composta do Ouvidor, do arrumador da agulha, dos ajudantes da corda, dos picadores do mato e de três testemunhas. Comeşam procedimento na beira da praia, onde é aberta uma cova para colocaşão de um marco de pedra, para certeza memória daquela divisão, medição e demarcação. Antes, porém, o porteiro do Conselho municipal, que também integrava a comitiva, faz pregöes para averiguar se havia alguma pessoa ou pessoas que tivessem alguma dívida ou embargos com que se opusessem a que naquele sitio e lugar se cravasse o referido marco. Sendo a resposta negativa, a pedra foi colocada no lugar. $O$ arrumador então coloca agulha, marcou e determina-se a direção a ser seguida: norte, sul, leste ou oeste. Os picadores vão abrindo uma trilha pelo meio do mato e, colocando-se uma ponta da corda junto a bússola, inicia-se a medição das águas pré-determinadas. As distâncias pretendidas só não são integralmente demarcadas quando acontece da comitiva encontrar um grupo de indios. No ponto em questão, da uma melhor medição por terminada e batem em retirada. (ALBUQUERQUE, 2006, p. 13)

No início da década de 1770, o interior do Brasil era pouco povoado devido à ordem da Coroa de privilegiar o povoamento do litoral, pois a mesma tinha receio de invasões no seu território. Sendo assim, o transporte marítimo era importante para as trocas comerciais. A vila importava aguardente, vinho, azeite doce, óleo de mamona ou de peixe, fumo, açúcar, carne, arroz e panos de algodão e brim real. Exportava peixe seco e farinha de mandioca.

O Príncipe Maximiliano de Wied-Neuwied, em sua vinda ao Brasil entre os anos de 1815 a 1817, descreve a sua chegada à Vila Viçosa:

...perdemos o caminho, e fomos parar na boca do Peruipe, onde encontramos esparsas cabanas de pescadores. Tivemos que voltar. Era pleno dia, quando, saindo das capoeiras, entramos num campo verdejante a margem do rio, e vimos, sob um encantador coqueiral, a Vila Viçosa, formada por cerca de 100 casas. Um edifício branco, destacando-se, pelo tamanho, das construcões acachapadas circunjacentes, se reconbecia logo como sendo a "Casa da Câmara", ou Edifício Real; dirigimo-nos para lá, e encontramos o "owvidor" em companbia de dois capitães navais, José da Trinidade e Silveira José Manoel de Araújo, que, conforme se disse, foram contratados pelo governo para fazer um levantamento astronômico desse litoral e organizar uma carta. O séquito do "ouvidor" era o 
mais misturado possivel, pois, além de alguns portugueses e escravos negros, incluía dez. ou doze jovens botocudos de Belmonte, e um rapaz. Machacali. (MAXIMILIANO, 1942, p. 175)

Maximiliano continua descrevendo a região, agora descrevendo o Rio Peruípe e seus vários canais, que compõem uma série de ilhas:

A tardinha, a viagem tornou-se extremamente agradável; saíamos de um canal para outro, pois que entre Viçosa e Caravelas há um verdadeiro labirinto, formado por uma multidão de ilhas de "mangues". Bandos de papagaios vozeavam nas capoeiras, mas eram todos da espécie da "curica". Vimos garras brancas sobre as curiosas raizes dos "mangues", que, brotando muito alto do tronco, inclinando-se sobre a água e enraizando-se na terra, formavam perfeitas arcadas em várias direções. Uma pequena espécie de ostra se encontra em abundância na casca dessas árvores, bem como, também em grande quantidade, o caranguejo multicor chamado "aratu". (MAXIMILIANO, 1942, p. 176)

Como já foi dito, assim como acontecia em Belmonte, o mar e o rio tinham grande importância econômica, pois era através deles que acontecia a circulação das mercadorias. Maximiliano conta quais produtos eram exportados e como. Também fala sobre um carpinteiro naval inglês, habitante da região:

Vila Viçosa é um vilarejo, aprazivelmente situado entre coqueiros. Mantém algum comércio de farinha de mandioca, que é exportada pela costa. Diz-se que, no último ano, a quantidade exportada atingin 9000 alqueires, no valor de 9000 cruzados. Diversos habitantes possuem pequenas lanchas, nas quais exportam, por mar, o produto de suas plantações. Ai vive um carpinteiro naval alemão; trouxe-o um navio inglês, que naufragou, e atualmente exerce a sua profissão; veio logo visitar-nos; porém só muito mal fala ainda a sua língua nativa; consideramno inglês no lugar. (MAXIMILIANO, 1942, p. 197)

Albuquerque nos conta que a partir de 1808 algumas colônias agrícolas foram estabelecidas no litoral da Bahia, após D. João VI promulgar um decreto autorizando a cessão de terras a estrangeiros. Como consequência, em 1818 foi criada a colônia Leopoldina, nas margens do Rio Peruípe, pelo botânico e naturalista alemão Georg Wilhem Freireyss, que participava da comitiva do príncipe Maximiliano de Wied, pelo naturalista Morhardt e pelo cônsul de Hamburgo na Bahia, Peter Peycke. Nessa colônia se plantava café. A colônia Leopoldina atualmente é a cidade de Helvécia. O trabalho na colônia era feito pelos escravos negros. Pouco depois chegam os suíços Abraão Langhans e David Pache.

Uma outra colônia estrangeira surge na margem esquerda do rio Peruípe, fundada pelo major-médico Georg Anton Schäffer, pelo João Martinho Flach, pelo Phillipe Hennig, alguns colonos e um criado. Era a colônia de Frankenthal, pois esses primeiros colonos eram francos de nascença. De acordo com Cardoso: 
A Fazenda de Jõa Martinho Flak era bastante organizada, possuindo rica mobilia importada da Europa, inclusive pianos que serviam para musicar as grandes festas, que todo mês um fazendeiro promovia e convidava os colegas para tomarem parte. Era servida por 1.000 (um mil) escravos, com casa e senzala e farmácia, médico e professores de línguas para os filhos do fazendeiro e seus empregados mais graduados. Os escravos não tinham escolas, mas podiam praticar a sua religião e promover festas em dias permitidos pelo fazendeiro. (CARDOSO, 1982, p. 26)

As duas colônias, Leopoldina e Frankenthal, fundiram-se e o principal produto agrícola plantado era o café, mas também cultivavam arroz, feijão, milho, cana, mandioca e algodão, em pequenas quantidades, só para consumo próprio. O Rio Peruípe era fundamental para o transporte da mercadoria, ainda segundo Cardoso:

\begin{abstract}
As fazendas localizadas na colônia Leopoldina importavam e exportavam mercadorias através de uma estrada carroçavel até o Porto de São José do Peruípe ou então por canoas até o Porto de Helvécia, por pequenas embarcações navegando no Rio Peruipe, com entrada pelo Ribeirão do Sertão, em frente a Helvécia... Os navios que transportavam estas mercadorias chegavam ao Porto de São José do Peruípe entrando pela barra de Caravelas, e Rio Peruipe. Para que o Peruípe pudesse ser francamente navegável, do Porto de São José até às fazendas mais afastadas, cada fazendeiro estabelecido às margens do Peruipe mandava soltar as represas existentes na sede da fazenda em um dos afluentes do mesmo rio. Assim procedendo, o rio crescia de volume e todo mundo podia viajar até ao porto. Quando o navio tinha de regressar à Europa, se fazia o mesmo, isto é, soltavam as represas... ... Exportava-se muita madeira, especialmente Jacarandá em pequenas toras, para a confeç̧ão de móveis na França. (CARDOSO, 1982, p. 26)
\end{abstract}

Em 1822 , com a independência do Brasil, o major Schäffer, da colônia Frankenthal, vai para Alemanha desempenhar funções diplomáticas para o governo imperial Brasileiro. Lá ele publica um livro sobre o Brasil, contribuindo para a primeira grande imigração de alemães para cá, cerca de 2 mil soldados e 5 mil artífices e colonos.

A Colônia Leopoldina era uma rica zona agrícola que produzia grande quantidade de café, até 80.000 arrobas por ano. Ela era composta por 40 ou 50 fazendas, com uma longa cadeia de cafezais em ambas as margens do rio. Ela também possuía máquinas de serrar madeira e beneficiar café, movidas pela força hidráulica de uma represa. Apesar de fazer parte do território de Vila Viçosa, ela prosperava mais do que a própria vila, fato que fazia com que muitos habitantes se deslocassem para a Colônia, fixando-se nela.

Em 1882, é criada a estrada de ferro Bahia e Minas, ligando os centros produtores de Minas Gerais ao litoral da Bahia e em 1888 ajudando no escoamento dos produtos agrícolas e no transporte de madeira entre o interior do território e o litoral, onde boa parte era exportada. Com a abolição da escravidão, a Colônia Leopoldina fica sem mão de obra e encaminha um pedido ao governo da Província para obter colonos 
portugueses, casados e com filhos para trabalhar na fazenda.

Com a abolição da Escravidão, a produção do café da Colônia Leopoldina praticamente acabou. Em 1920, a Vila Viçosa estava em grande decadência, principalmente com a diminuição da produção de café na Colônia Leopoldina. Como consequência, muitos habitantes foram para outros estados ou retornaram para seus países de origem.

Em decorrência da decadência, em 1931 o município de Vila Viçosa foi anexado ao de Mucuri, pois não havia quem assumisse a administração municipal. Em 1944 o distrito teve seu nome mudado para Marobá (f.26); em 1953 passou a ser chamado Nova Viçosa.

As atividades econômicas de Viçosa (f.24), entre 1931 e 1950, eram principalmente a pesca e a venda de lenha a metro para os navios da Companhia Bahiana de Navegação. Em 1950 uma empresa de processamento de madeira, a Elecunha, transfere-se de São Mateus para Nova Viçosa. Começa com uma serraria e, em 1960, é inaugurada a seção de compensados. A fábrica era operada por técnicos trazidos do Japão. Esses técnicos também eram os responsáveis por treinar os trabalhadores locais. Muitos navios estrangeiros atracavam no porto da companhia para carregamento de madeira que ia, principalmente, para os Estados Unidos.

Com a instalação da Elecunha, Nova Viçosa teve um novo crescimento, levando-a a se emancipar em 1962, desmembrando-se das cidades de Caravelas e Mucuri.

Dr. Sávio, amigo de Zanine, foi o médico da madeireira até final da década de 1950, quando mudou-se para Brasília. Segundo depoimento de Cydno Silveira ${ }^{1}$ concedido à pesquisadora, Dr. Sávio gostava muito de Nova Viçosa, contando com frequência sobre sua experiência no Sul da Bahia, e foi com ele que Zanine chegou, pela primeira vez, entre 1969 e 1970, em Nova Viçosa ${ }^{2}$ (f.29).

A Elecunha possuía diversos produtos de madeira, como laminado colado (f.28) e pisos, mas também produzia telhas francesas, tijolos furados; formou grande número de profissionais aptos a trabalhar com madeira. Além disso, a cultura construtiva dos habitantes da cidade era voltada para o saber-fazer em madeira, desenvolvendo objetos que fossem capazes de solucionar as necessidades do dia a dia.

Numa cidade de pescadores com um grande rio, o Peruípe, ligando o interior de Minas Gerais ao mar, a comunicação entre Nova Viçosa e Caravelas é feita por canais naturais estreitos e rasos, que passam entre uma série de ilhas. Essa região possui uma rica extensão de manguezais, criadouros naturais de diversos peixes e caranguejos. Para

1 Entrevista realizada em 09.11.2017.

2 Questão levantada durante primeira ida a Nova Viçosa, quando alguns dos entrevistados disseram que Zanine chegou à cidade ao lado do Dr. Sávio. Após essa viagem, esse fato foi confirmado pela filha do Dr. Sávio, Claudia Orthof, em entrevista realizada no dia 08 de novembro de 2017, e pelo arquiteto Cydno Silveira, em entrevista realizada no dia 09 de novembro de 2017. 


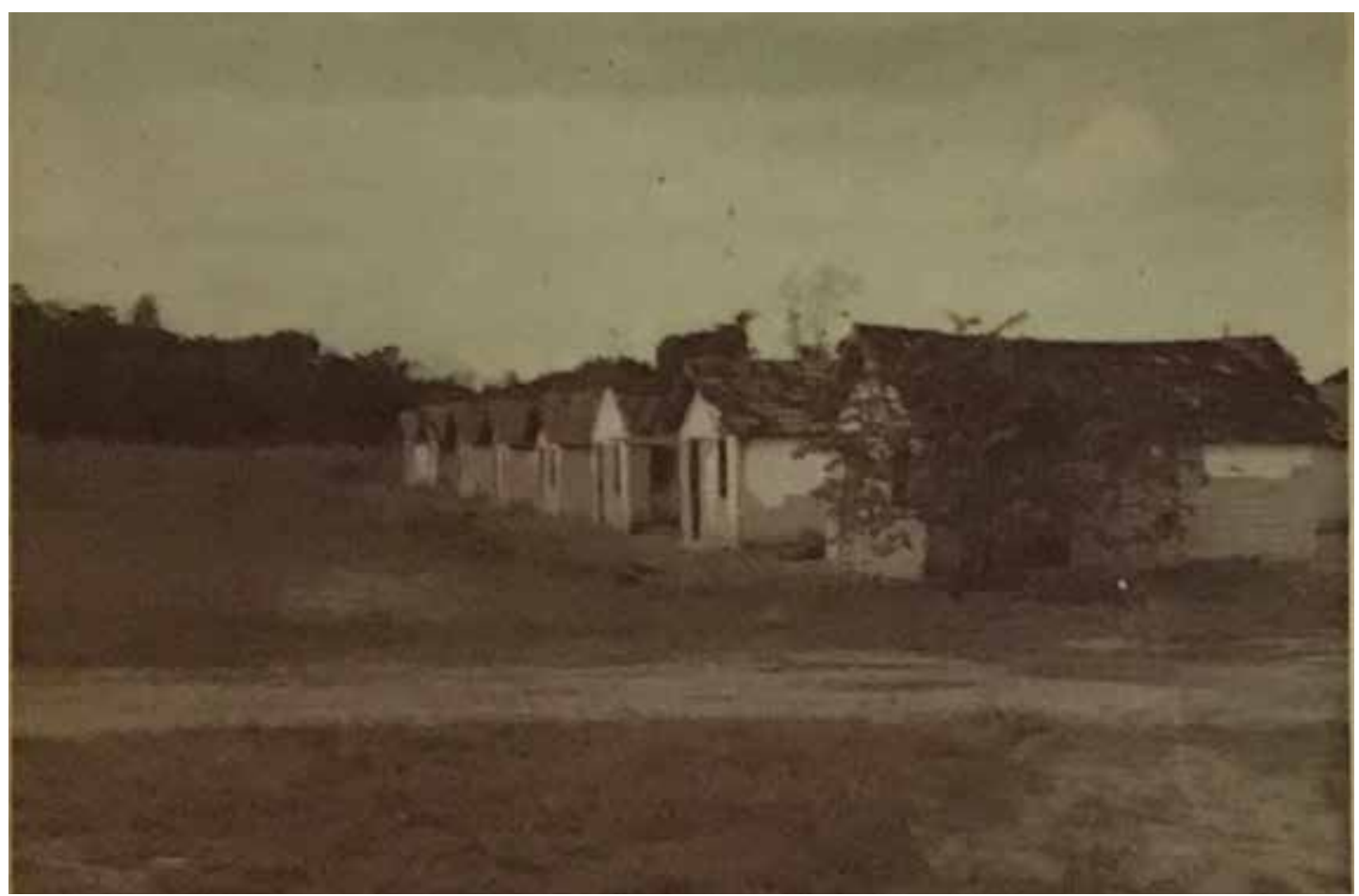

Figura 26. Marobá em 1950. Fonte: acervo pessoal de Carlos Fanticelli.

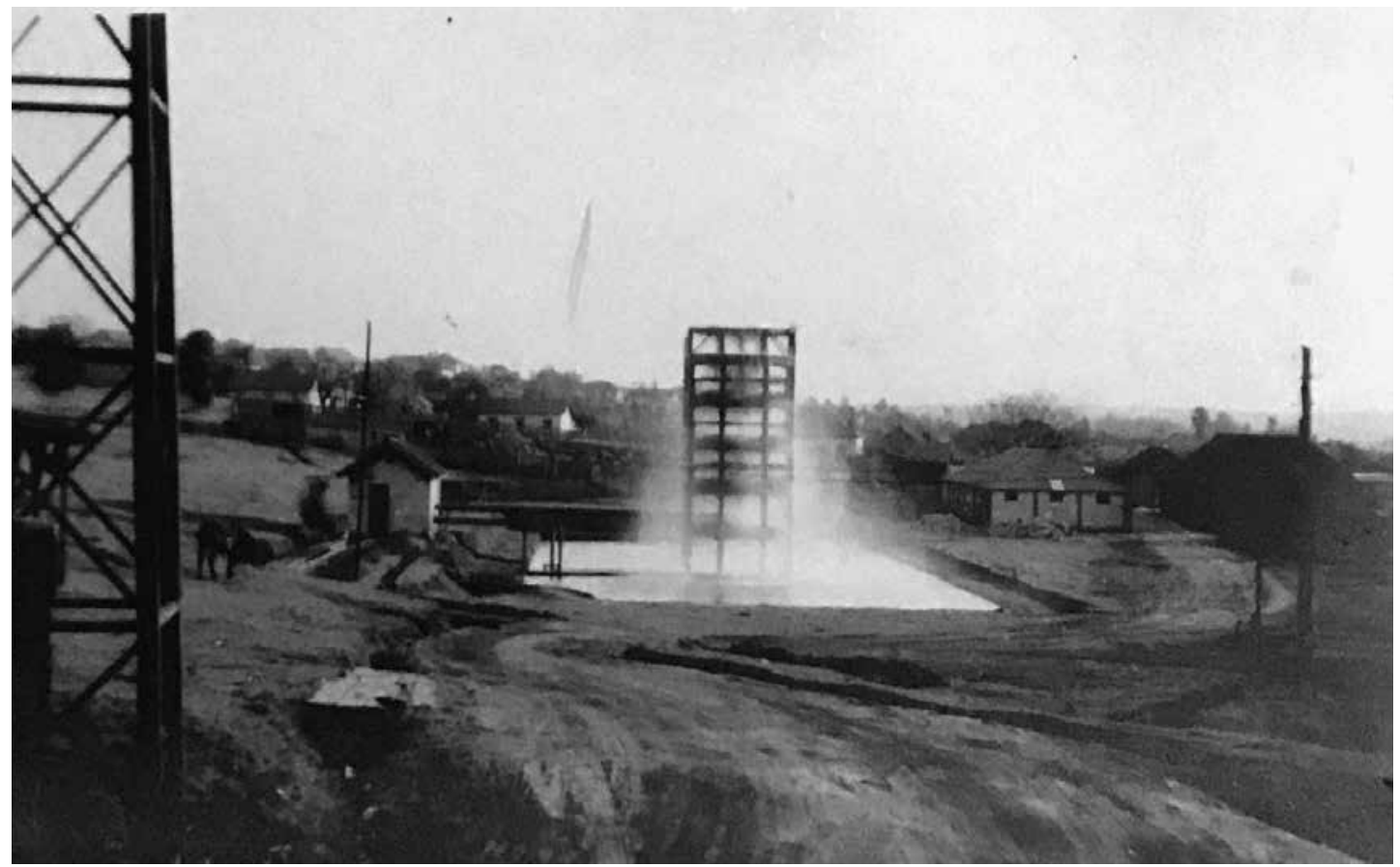

Figura 27. Elecunha em 1950. Fonte: acervo pessoal de Carlos Fanticelli. 
Figura 28. Fabriação de laminado na Elecunha. Fonte:

Carlos Fanticelli.

o pescador percorrer a região é preciso um barco pouco profundo e silencioso. Com a farta existência de árvores grandes, esses pescadores aprenderam a transformar os troncos das mesmas em canoas, usando a enxó.

Além de habilidosos construtores de canoa, Zanine também encontrou uma farta quantidade de sobras de madeira provenientes da madeireira Elecunha. Ao cortarem o tronco da árvore, deixavam as raízes, que eram queimadas posteriormente. Além disso, a técnica de fabricação do compensado tira lâminas externas do tronco, sobrando o cerne.

Essa madeireira era muito grande, conforme depoimento de Carlos:

Lolô Cunba já tinha uma fábrica no Espirito Santo. Resolveu tražer essa empresa para Nova Viçosa. Montou essa empresa, uma mega empresa, na época uma das maiores empresas do Brasil. Tinha embarcação: na época o maior barco da América Latina feito em madeira era da Eleusippo Cunba, chamado Barão. O Barão e o Timbira. Ai foi instalada essa empresa aqui. (FANTICELLI, entrevista de 19/08/2017)

O Eleosippo Rodrigues Cunha, conhecido na cidade como Seu Lolô Cunha, era o dono da Elecunha. Segundo Tancredo, quando Zanine foi para Nova Viçosa, Afrânio Cunha era o diretor da empresa e cedeu um galpão para Zanine trabalhar, utilizando os restos da madeireira. Ainda de acordo com Seu Tancredo ${ }^{3}$,

Nós vínhamos pra cá, pra nós trabalhar umas casas na praia, no rio do Pau Alto, depois que terminou essas casas ele começou a faz̧er os móveis lá na Elecunha. Os móveis de cabeça de pau, os restos que a firma cortava, aquelas toras, ai ele comecava a fazer mesas, algumas poltronas, e por ali passou. Ai depois que fez o galpão, que ele comprou, ai ele mudou, pra fazer outros tipos de móveis. Fazia o sofá namorada, fazia outras cadeiras espreguiçadeiras. (BARROS, entrevista de 19/08/2017)

3 Seu Tancredo foi um dos primeiros carpinteiros a trabalhar com o Zanine. Comecou com ele na Elecunha e, depois, foi para o galpão construído por Zanine. Outros depoimentos confirmam que Zanine começou seu trabalho no galpão cedido pela Elecunha, como o do Carlos Fanticelli: "Zanine veio para cá, para trabalhar não na Elecunha, e sim dentro da Elecunha, cedido um espaço. Como en conheci Zanine? Como eu era adolescente, a gente não tinha escola integral. Meu pai sempre falava assim: 'filho na escola, outro periodo ta na empresa comigo'. Ai todos os filhos do meu pai, eu Almácio, Gleris, os filhos homens, desde os 10 anos eu trabalhava na Elecunha. Quando eu passava pela casa do ponto, a casa do ponto era onde batia o cartão, todos os funcionários passavam para bater o cartão. Ao lado, do lado esquerdo, tinha um ponto que tinha uma área reservada, que eu não sabia quem era. Eu via, era adolescente, um cara lá, trabalhando, mexendo com madeira. Também não importava, eu não sabia. E sempre aquilo foi indo, passando, e veio o nome, a gente nem conhecia como Zanine, porque o nome era muito dificil de ser pronunciado por um nativo. A gente conhecia 'o homem de rabo de cavalo'. (FANTICELLI, 19/08/2017) 
INDÚSTRIA E COMÉRCIO

TORNO_COB de 110 , vendo-se ao fundo a direita o conjunto automático de enrolar e desen rolar folhas,-em Operação.

Secador COR-de 4 linhss 8 seções, na fase de montagem.

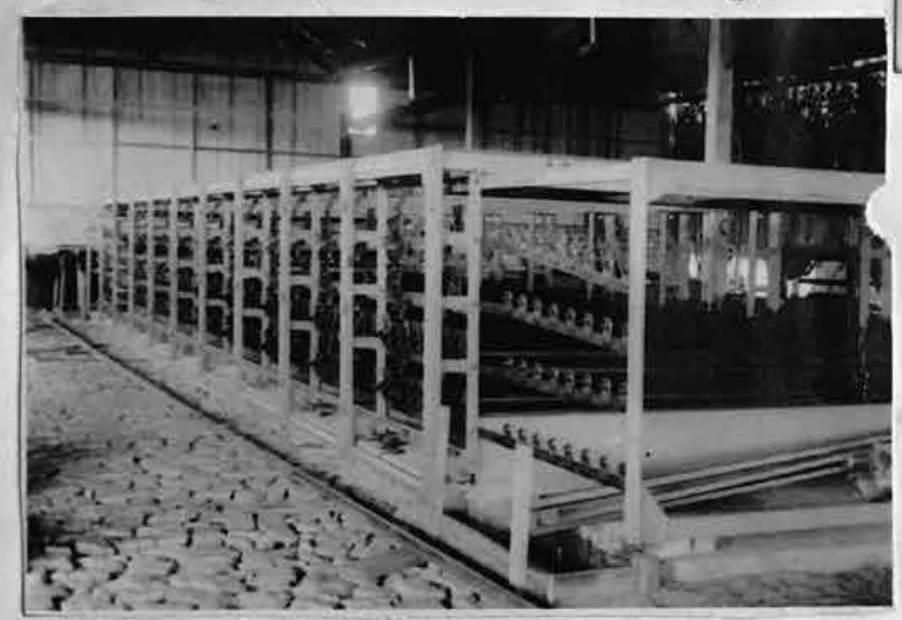

Secador COB- de 3 linhas e 4 seçôes, na fase de montagem.

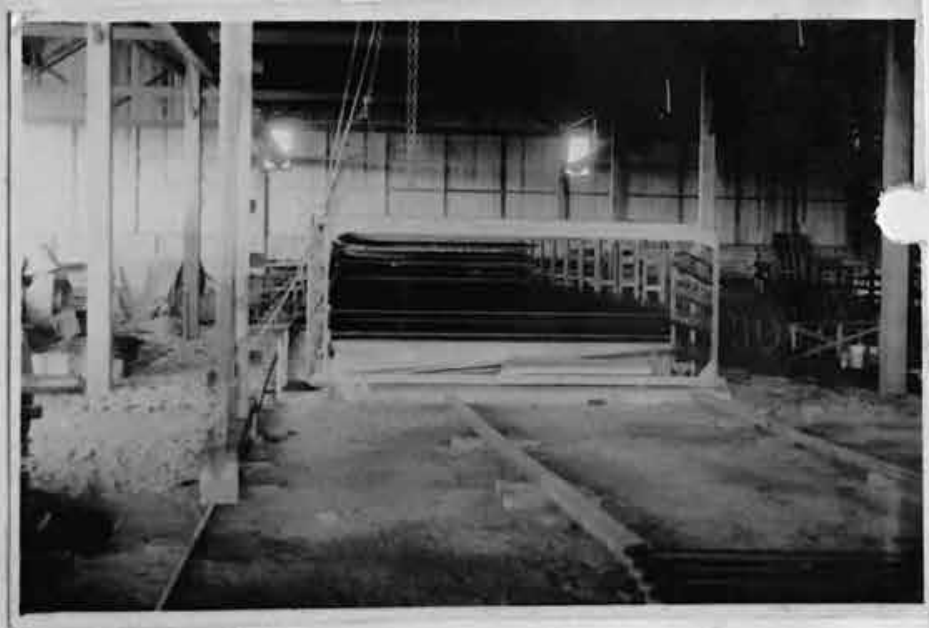

Construção de TANQUES de concreto, para cozimento de TORAS.

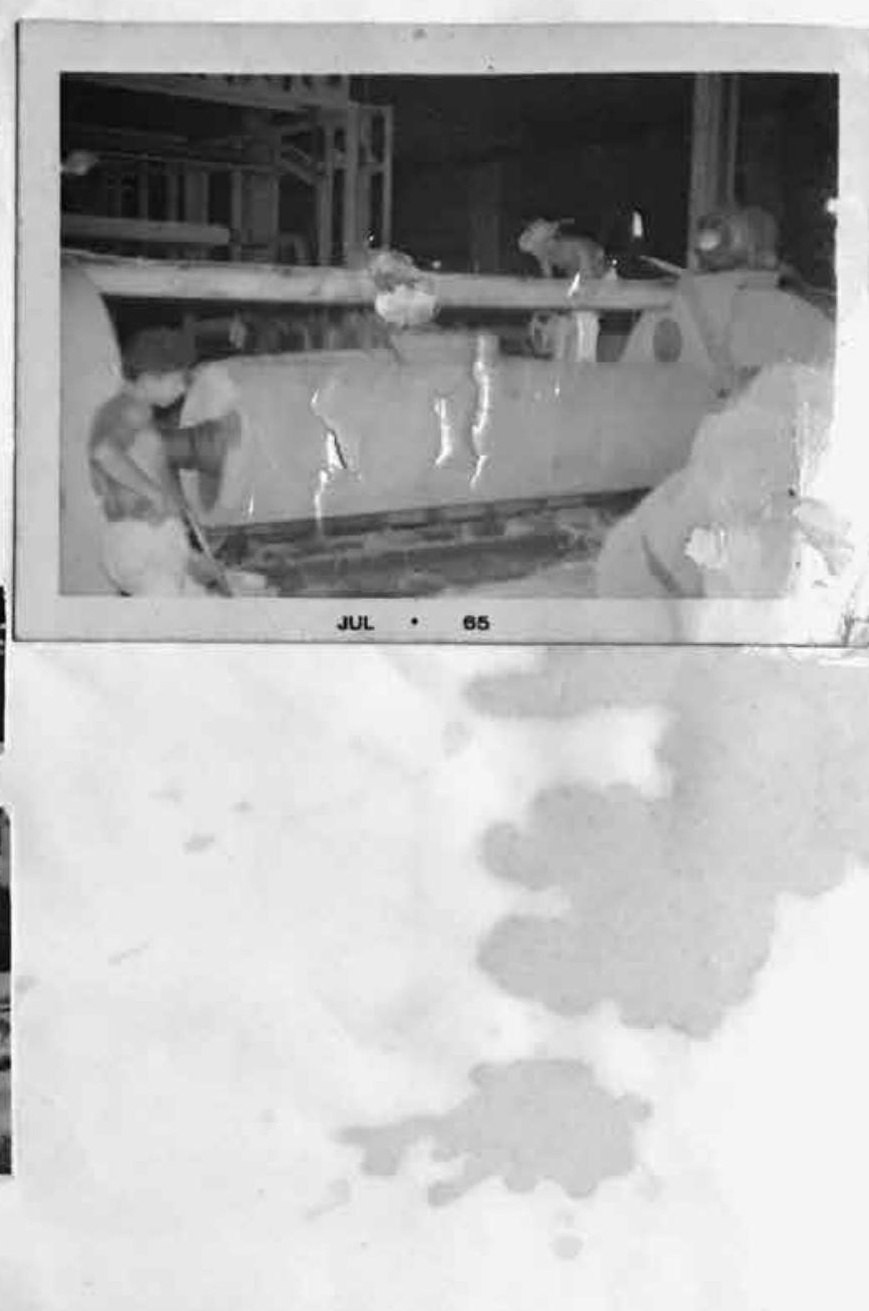


De acordo com Carlos, no galpão cedido pela Elecunha tinha uma guilhotina, que servia para a empresa seccionar os pedaços de madeira que sobravam, para serem usados nas caldeiras da fábrica. E foram esses alguns dos pedaços que Zanine usou nos seus móveis.

Onde ele instalou a oficina dele tinha uma serra que cortava os tocos. E tinha outra, que o nativo chamava de bate-estaca. Na verdade, não era um bate-estaca. Era uma guilhotina, onde se pegava aquilo que se achava que não servia, ele soltava aquela guilhotina e cortava os pedaços de tronco para queimar na caldeira. (FANTICELLI, entrevisra de 19/08/2017)

Zanine nomeou esse tipo de móvel de "móvel denúncia" e, segundo ele mesmo:

(...) Lá em Nova Viçosa eu faço uma denúncia, dou um testemunho: ao ver aquelas madeiras imensas serem queimadas e jogadas fora, eu pego a madeira bruta e transformo em um móvel nas dimensões naturais. Aí eu também peco, porque uma peça dessas só pode adquirir quem tem dinheiro. (CALDAS apud LOSCHIAVO, 2015, p. 153)

Nesses primeiros anos em que esteve em Nova Viçosa, Zanine planejou criar uma cidade ecologicamente sustentável e que se estruturasse a partir da arte e dos saberes da região. 


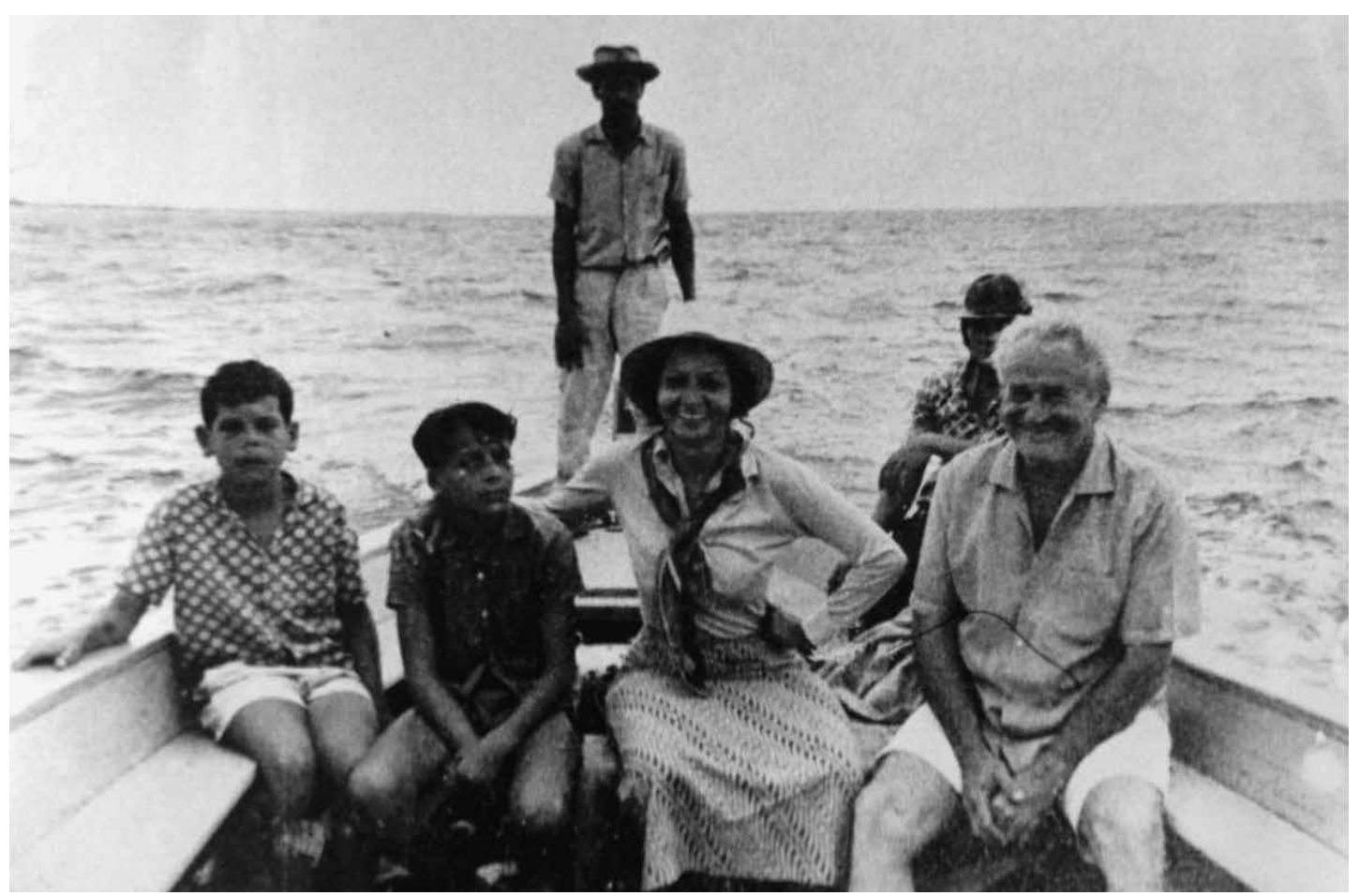

Figura 29. Delz̧a e Dr. Sávio em Nova Viçosa. Fonte: Acervo pessoal de Déa de Zanine.
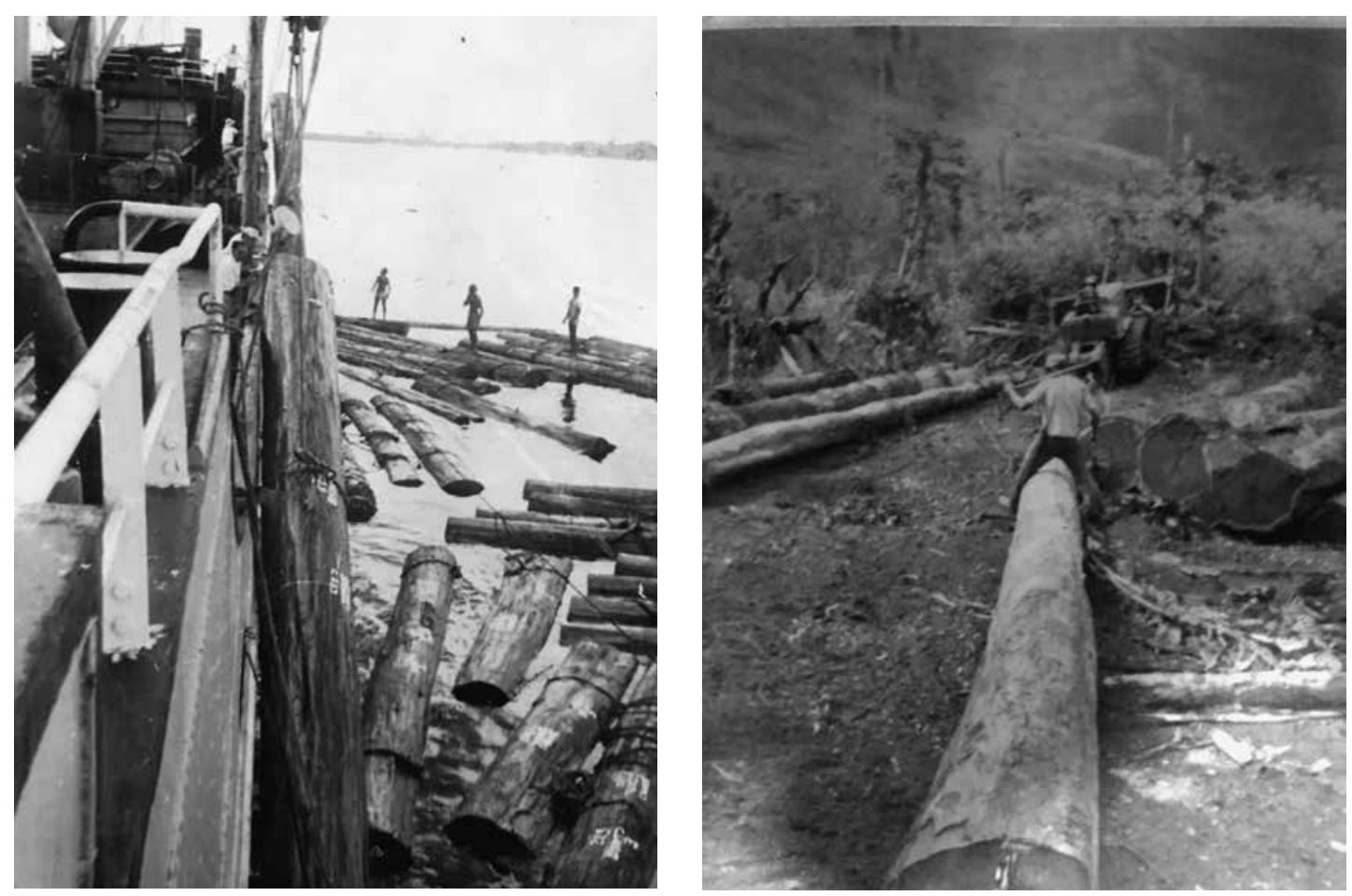

Figuras 30 e 31. Madeiras chegando em Nova Viçosa e o desflorestamento na região. Fonte: Carlos Fanticelli. 


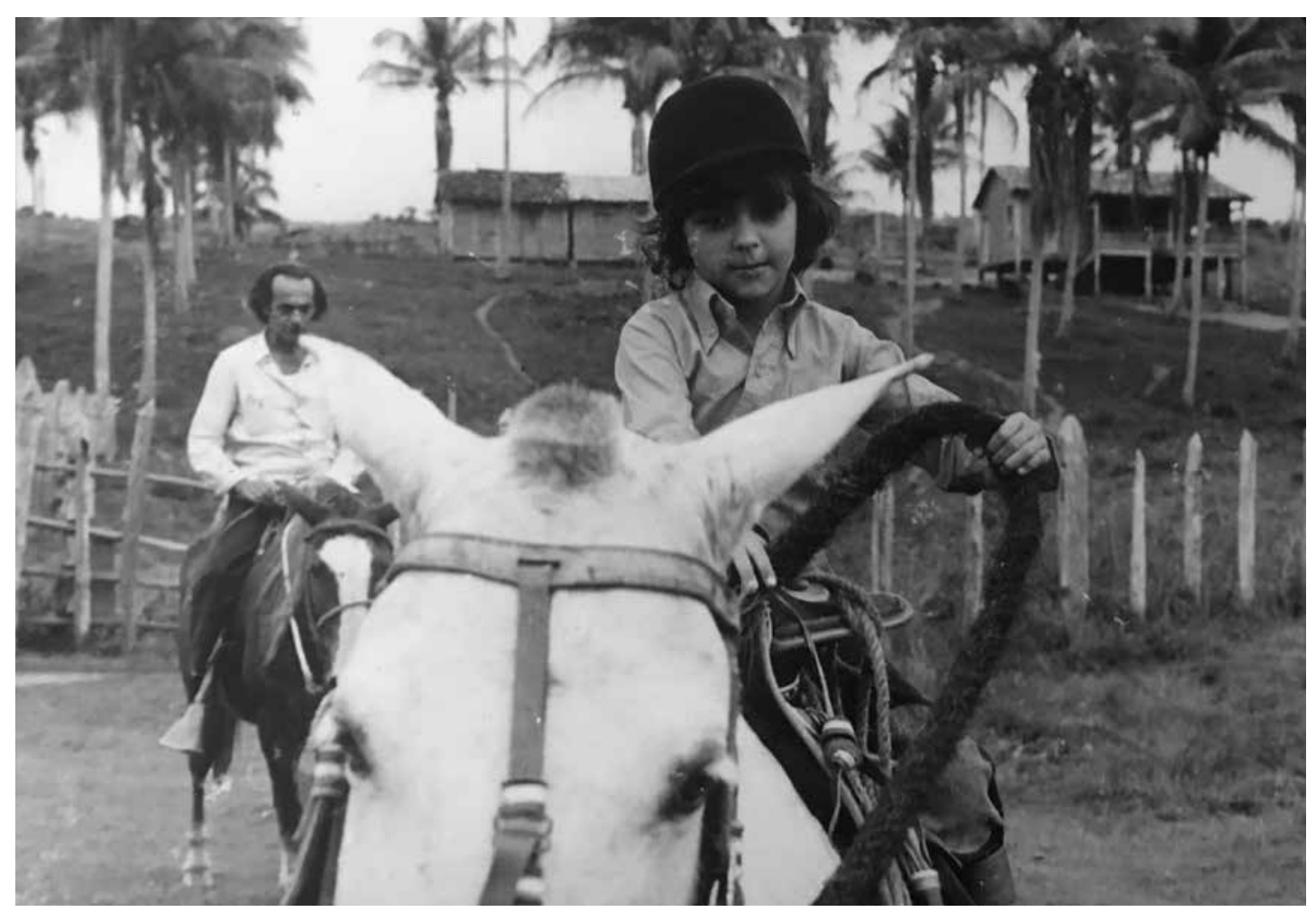

Figura 32. Déa e Zanine em Nova Viçosa. Fonte: Acervo pessoal de Déa de Zanine.

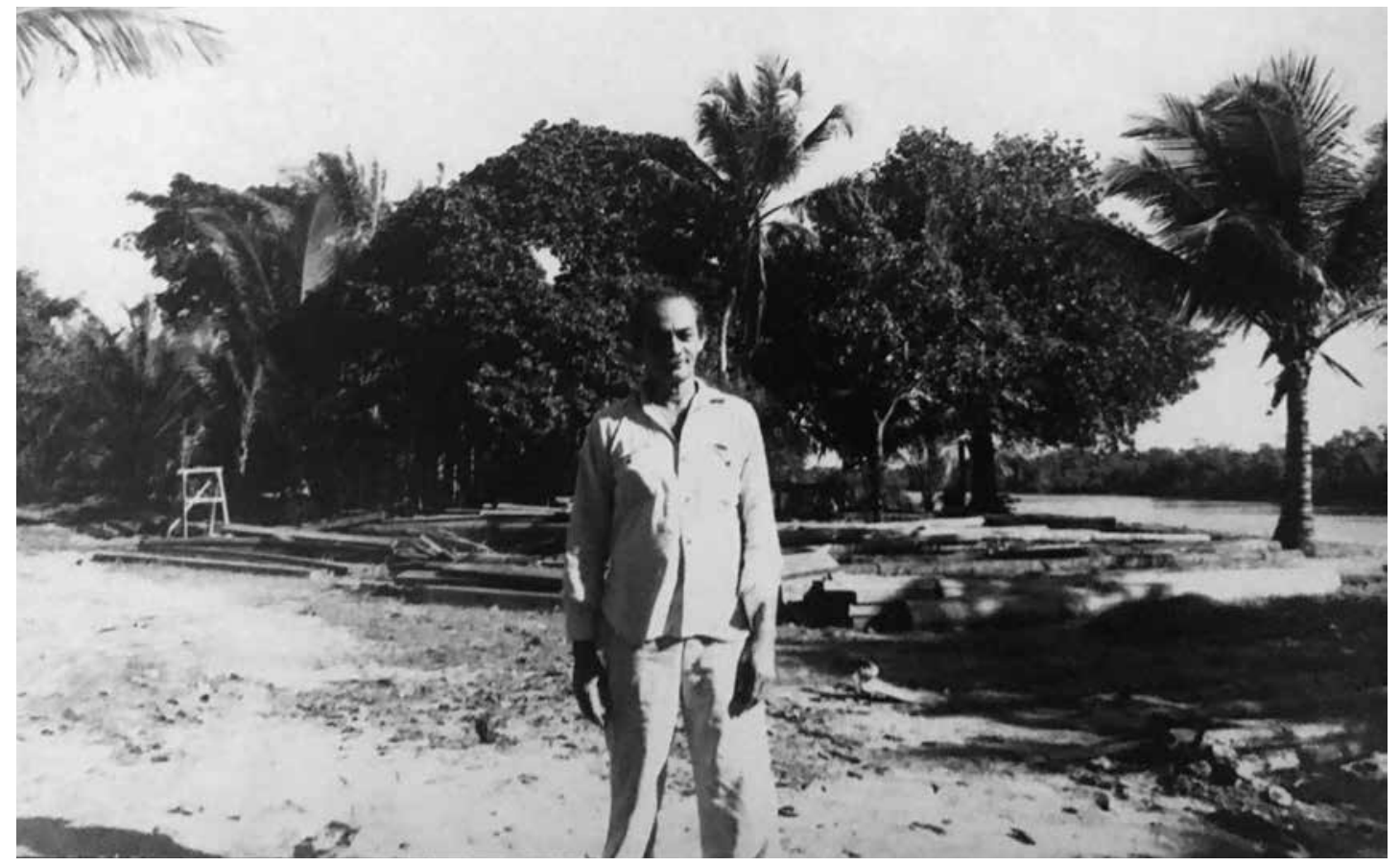

Figura 33. Zanine em Nova Viçosa. Fonte: Acervo pessoal de Déa de Zanine. 


\section{projeto}

\section{urbanístico}

Em 1970, Nova Viçosa era muito afastada das principais vias de circulação do País, a BR-101 não era construída e a principal ligação com as maiores cidades acontecia através da estrada de ferro Bahia e Minas, cuja estação mais próxima era a de Caravelas, onde pegavam um barco para chegarem até Nova Viçosa. Em 1971 foi criada a linha de ônibus ligando Nanuque a Nova Viçosa, mas mesmo assim a viagem era difícil, pois a estrada era de areia e exigia eventuais paradas para colocar vegetação no piso, evitando atolamentos. Sendo assim, quando Zanine chegou em Nova Viçosa, encontrou um pequeno vilarejo, um local lindo, com rica diversidade de vegetação nativa, belos manguezais e ainda não descoberto pelo turismo.

Uma das grandes belezas do período em que Zanine morou em Nova Viçosa foi a crença em projetar uma cidade. Para quem viu uma capital inteira construída em 3 anos, como Brasília, o sonho da criação de uma cidade não era distante da sua concretização. Uma pequena vila, naturalmente rica e bela para servir de suporte para os desejos do habitar. Como poderia ser essa cidade? Talvez do tamanho dos sonhos de Zanine. E, acreditando nisso, ele fez o projeto urbanístico de Nova Viçosa e o apresentou para o prefeito da época, conseguindo em troca do projeto e da abertura das ruas do mesmo algumas glebas mais afastadas do centro ${ }^{4}$.

Os maiores lotes eram divididos dos menores pela Av. Principal de Nova Viçosa, atual Avenida Oceânica, e ficavam próximos ao mar. Os menores ficavam em direção ao interior da cidade assim como o centro cívico.

Olhando o projeto (f.34), da esquerda para a direta temos as quadras C, E, E1 e H, que ficam entre o oceano atlântico e a estrada principal de Nova Viçosa. É interessante notar a forma das mesmas que, diferentes dos traçados regulares, são hexágonos irregulares, trapézios ou octógonos, deixando uma grande área para preservação da mata local. O formato do trapézio permite que todos os lotes tenham visão e recebam brisa direta do mar. Os lotes

4. Como Zanine não tinham formação de arquiteto, ele não podia assinar plantas, que sempre eram assinadas por outros arquitetos que trabalhavam com ele. 
Figura 34. Projeto urbanístico

para Nova Viçosa, década

de 1970. Fonte: Prefeitura de

Nova Viçosa.

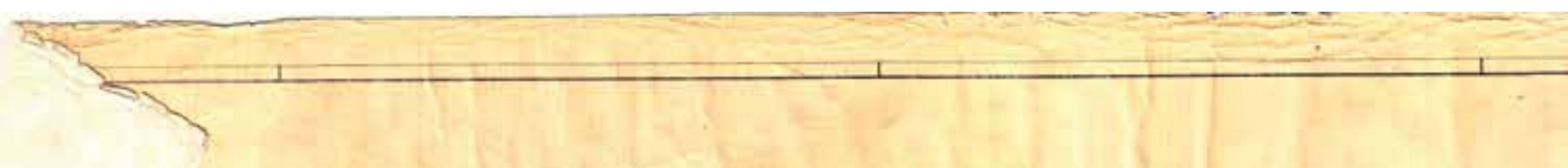

mis

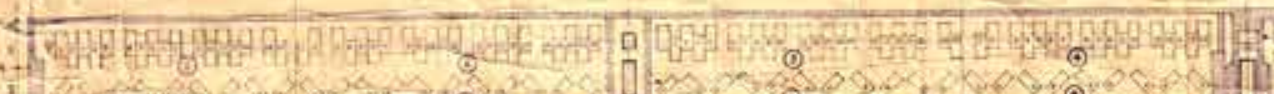
i. 3 (1)

$+\frac{2}{2}+200$

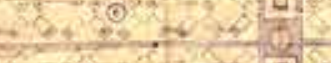

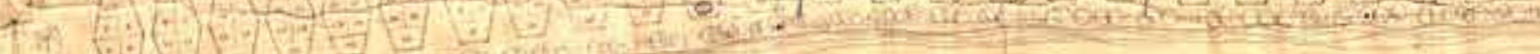

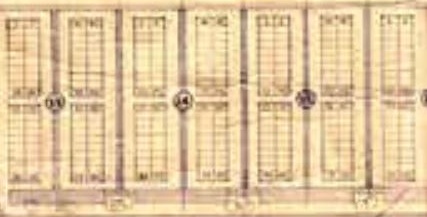
Lo

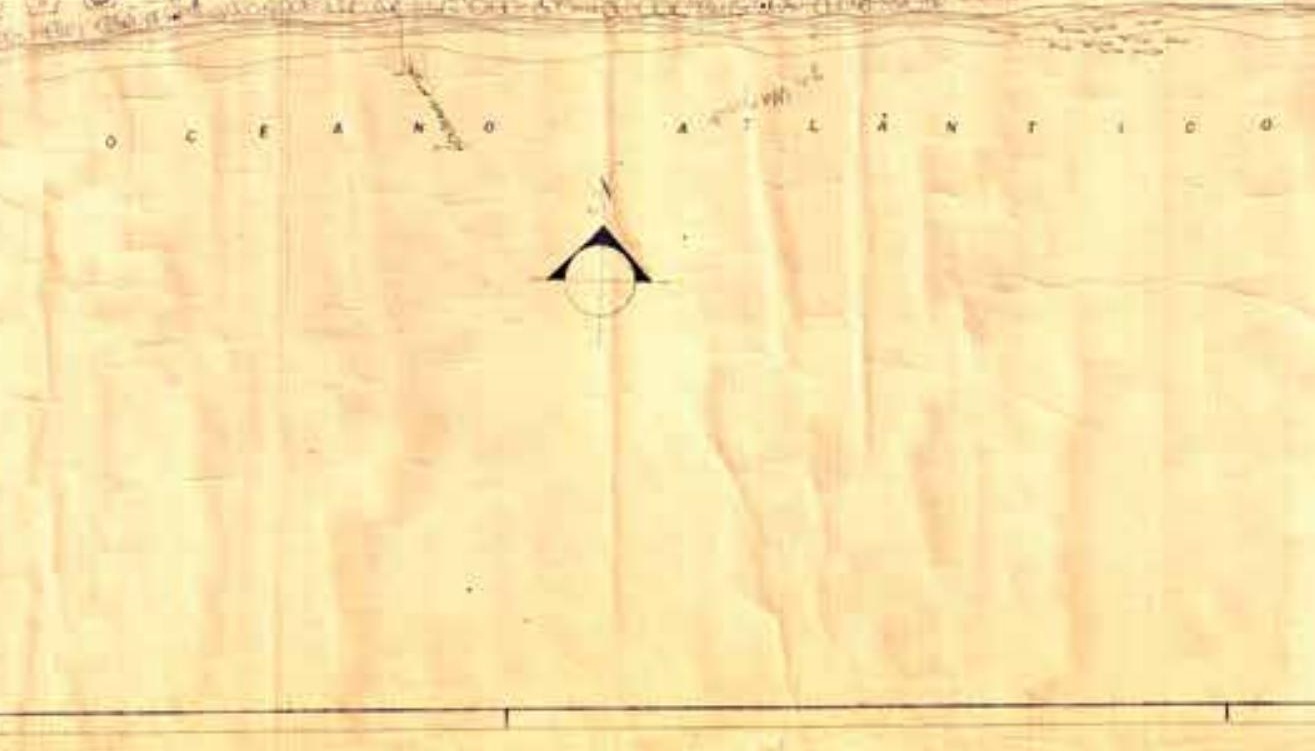




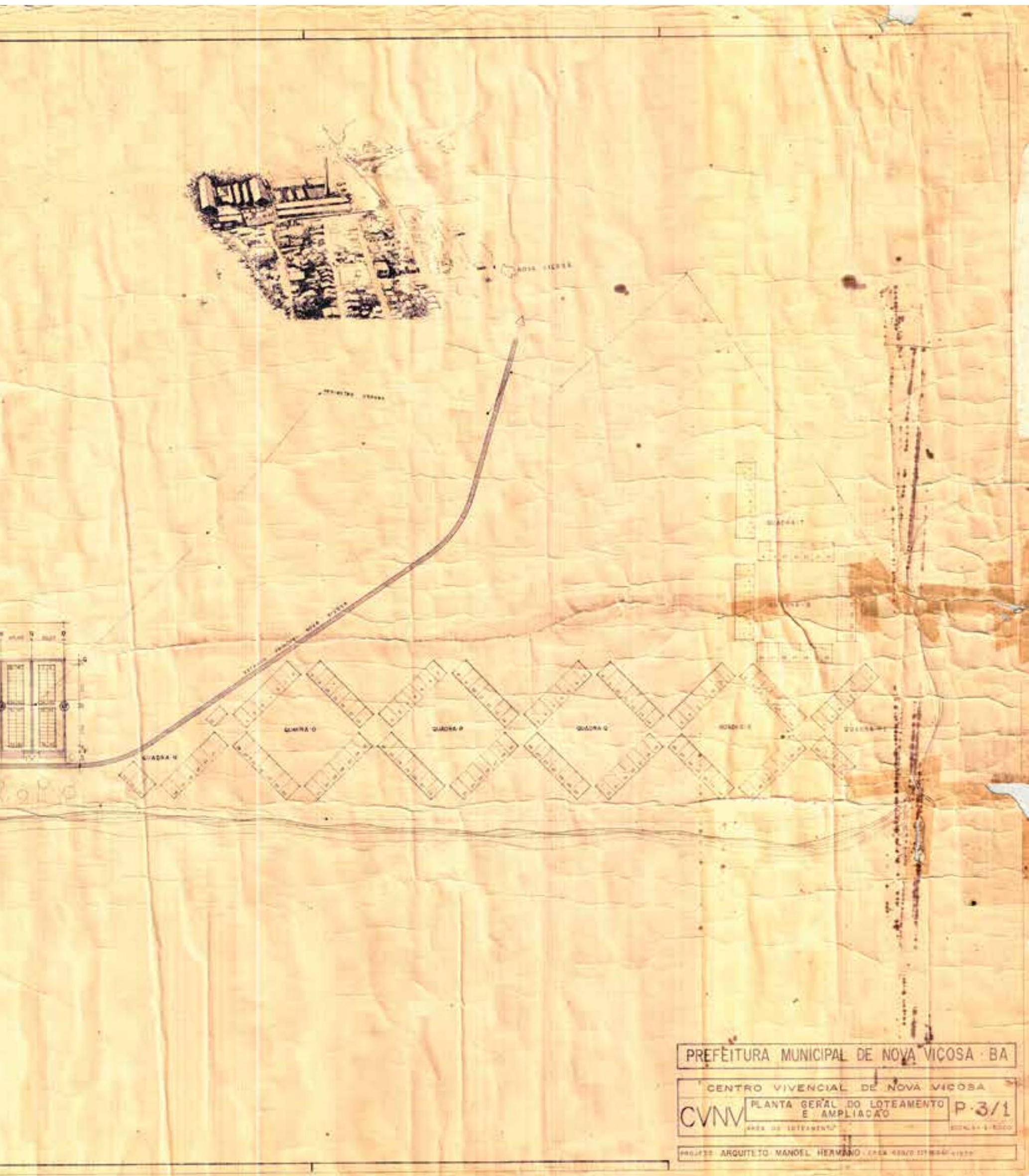


Figura 35. Notícia sobre

Nova Viçosa. Fonte: jornal O

Globo, 5/03/1975, p. 5.

variam entre aproximadamente $1.200 \mathrm{~m}^{2}$ e $490 \mathrm{~m}^{2}$, sendo maiores os voltados para o mar.

Continuando da esquerda para a direita, após essas quadras estava a área reservada para a colônia de pescadores e em seguida vinham as quadras $\mathrm{N}, \mathrm{O}, \mathrm{P}, \mathrm{Q}, \mathrm{R}, \mathrm{R} 1, \mathrm{~S}$ e T, que chegavam até a foz do Rio Peruípe. Essas quadras dispunham seus lotes formando um X e deixando muita área livre para vegetação, seguindo um dos princípios projetuais de Zanine para Nova Viçosa: valorizar a natureza. Segundo Teodório ${ }^{5}$, quando fala sobre esses terrenos:

Quando ele implantou o projeto, a filosofia dele, o plano dele é que não vendesse o terreno em si para o pretendente mas que adotasse um sistema de aforamento, de arrendamento longo. Então contrato inicial era por 25 anos, a pessoa podia fazer a benfeitoria que fosse necessária, obedecendo os critérios legais de preservação da natureza e esse projeto eram quadras retangulares com sete lotes formando um quadrilátero e o interior dessa quadra era vegetação. Tinha que se preservar ali e o que tinha de natural era a pitangueira, era cambucá, era o cajueiro. O que tinha de fruta natural tinha que permanecer e plantar mais. Essa era a ideia de Zanine. (CARDOSO, depoimento de 17/08/2017)

Analisando o mapa da esquerda para direita, mas agora da estrada principal de Nova Viçosa para o interior do território, temos lotes menores, em formato de $\mathrm{X}$ e grande área verde, duas ruas paralelas à via principal que chegam até o centro cívico e, continuando, quadras retangulares com lotes menores e ruas perpendiculares ao eixo principal.

O centro vivencial ganbará dimensão, a partir dos próximos anos, com a implantação do restante do projeto: um pomar com frutas nativas, colônia para os pescadores, áreas de recreação, viveiros de peixes, e a criação de escolas livres de arquitetura e arte. $(O$ GLOBO, 5/03/1975, p. 5)

De acordo com matéria do O Globo, pode-se supor que o centro cívico tivesse áreas comuns com escolas, praças, prédios administrativos, áreas para agricultura. Mas o projeto ia muito além do desenho urbanístico: Zanine sonhava criar uma cidade em que homem e natureza existissem de forma harmônica, para isso, além de valorizar os conhecimentos dos habitantes do local, que sabiam tirar da natureza o necessário para as suas necessidades e que entendiam que sua sobrevivência dependia da existência da natureza, preservando-a, tinha a intenção de atrair intelectuais e artistas para a cidade, pessoas capazes de respeitar a natureza, convidando-os a apoiar a sua ideia, comprando ou alguns dos terrenos da gleba de Zanine, ou terrenos do projeto urbanístico. Entre os apoiadores estavam: Krajcberg, Oscar Niemeyer, Chico Buarque de Holanda, Carlos

5 Na época, em 1971, Teodório era o secretário do então prefeito Tânus Correia das Neves e, como sabia usar o teodolito, trabalhou junto com o Zanine na abertura das ruas do projeto. 
Nova Viçosa

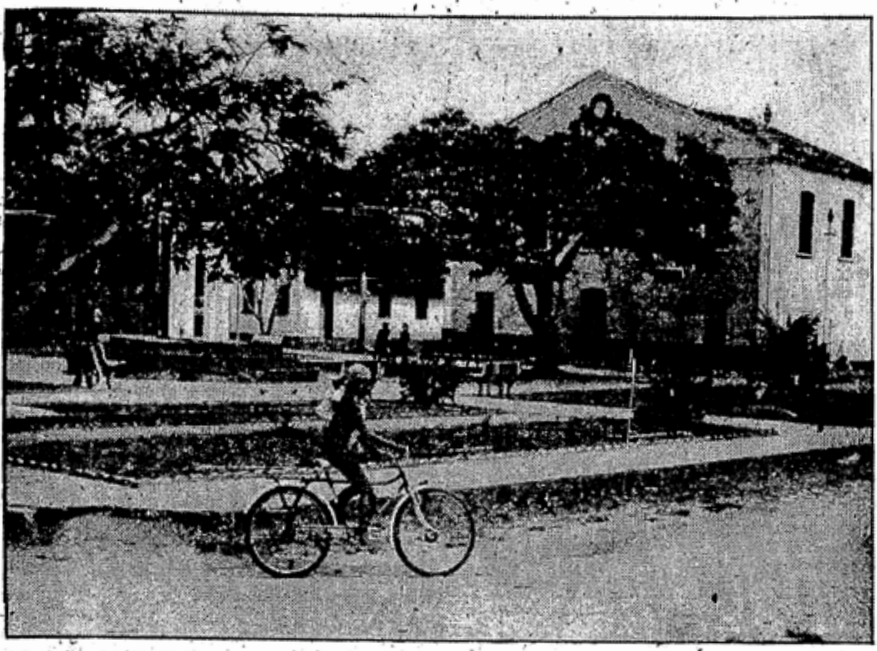

SALVADOR (O GLOBO) - Quando há quatro anos Zanini começou a implantar o Centro Vivencial de Nova'Viçosa - um projeto ambicioso e bem semelhante ao que ele executa em Sete Cidades e na foz do rio Parnaíba, 'amboś no Piauí - seus três mil habitantes estavam. longe de imaginar que a cidade, acostumada à intimidade com 0 anonimato e a pobreza, poderia se transformar num dos maiores cen tros turísticos do País passaria a atrair a atencăo de intelectuais e artistas brasileiros e europeus.

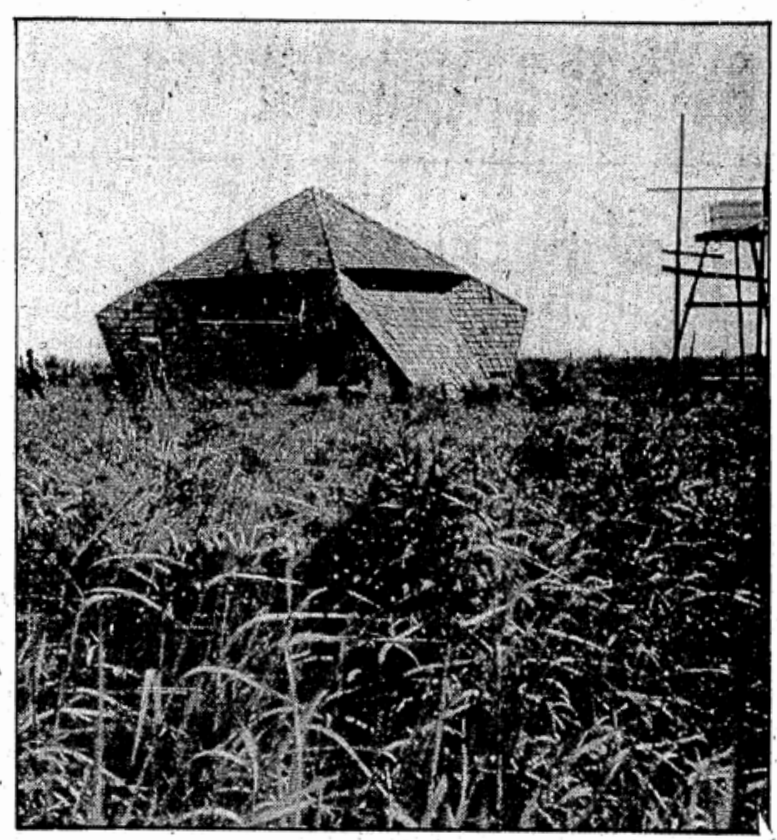

\section{No Sul da Bahia, Zanini e Krajcberg criam um paraiso para a arte e lazer}

$\mathbf{F}$ ol Justamente o que aconteceu: passados os
primelros anos de comercializáçấo dos lotes do primelros anos de comercializaçắo dos lotes do
Centro Vivèncial, que ocupa 280 hectares numa cada de coqueirais e florestas nativas, artistas de várias nacionalidades, liderados pelo escultor
Kracjberg, passaram a planejar a criação.em Nova Kracjberg, passaram a planejar a criação.em Nova
Viçosa de uma Escola Livre de Arte e Arquitetura. Assim, a cldade - onde ficam as mais bela praias do Extremo Sul da Bahia - até o fim da centros de cultura do Nordesté. Entusiasmados com os primelros resultados do projeto do Centro Vivenclal de Nova Viçosa -
que entre os seus futuros moradores já possul qunte famosa Chico Buarque de Holanda e Carlos Scliar - os dois assessores de Zaninl, Luiz Carlos Sllva otimismo: sem polulçăo, rica em cultura popular e tradiçóes herdadas dos colonizadores portugueses, franceses e alemães, a cidade vai transprejuizos para o meio-ambiente ou para a cultura - Traremos para o lugar gente que sabe apreclar a natuceza e, pela propria sensibilichade demar Guere valorizar a natureza- - analisma Unlversidade Federal da Bahla, que trocou o seu trabalho de repórter pelo de desenhista de plantas

\section{CONCENTRAÇÃo TOTAL}

Dlstante 842 quilómetros de Salvador; Novà Vlçosa, às margens da BR-101, é uma cidade onde - progresso do mundo moderno chega apenas
através do rádio e os sonhos de riqueza sobte. vivem apenas na memória dos seus moradores
mais antigos, que ouviram na infáncla hlstórias fantástlcas dos tempos em que navios franceses $\theta$ alemăes desciam o rio Peruipe - que corta 0
munićiplo de Norte a Sul - abarrotados de café. Desde a aboliçăo da escravatura, a decadência invadiu o municiplo, onde somente na cídade de sado cada vez mais distante. movimentaçãa. Viçosa nén esperanças haveria nenhuma Waldemar Guando chegamos para trabal har - conta possuia um único - a cidade nắo tinha nada: prefeifura e alguns caminhóes de uma fábrica de madelra que ainda funclona num regime feudal Nem picolé se vendia aqui: vocé precisava ver a

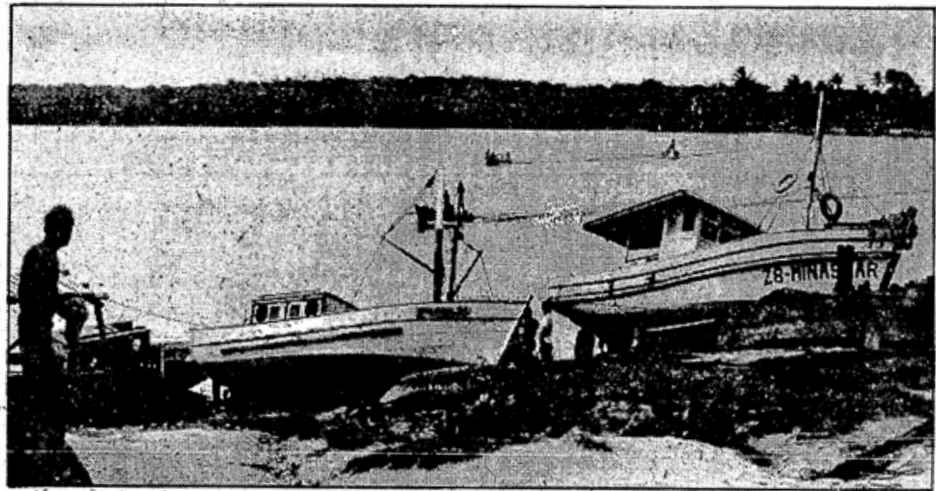
sorvete $\mathrm{e}$ se fabricou gelo pela primeira vez. mercio, na extração do ferro, no beneflciamento da madiada ás $\theta$, sobretudo, na pesca artesanal, foram sérios obstáculos a qualquer possibilldade de progresso.'

é Jara Zanini, o que Interessa em Nova Viços e justamente que nenhum dos seus habitantes cujo aproveitamento dependerá a partir de agora o futuro económico do municipio, por onde, no século XVI, passaram as primeiras
se dirigiam ao sertáo de Minas.
Encravada entre os municíplos de Mucuri e Caravelas, Nova Viçosa - onde existem prajas
com miais de 30 quilómetrós de extensáo - será do É Euiz Carlos da Silva. arquitetura moderna integrada As caracteristicas locais: criar um lugar propício à meditaçāo, con-
templação dá natureza e estudos - é o que nós nos proporios. 0 desejo de Zanini se resume em coisas simpies: quer desenvolver projetos què agradem a todos, mas fazendo com que as pes-
soas que venham morar aqul respeitem os cosA economia pobre, sustentadia no pequeno coreduzidas com a abertura da BR-101 - sempre

A pèsce
FORMYAS GEOMETRICAS

As casas do Centro Vivencial de Nova Viçosa s construcōes que geralmente aperecem em illt mes de flicção cientifica. $O$ desenho mais sofis. icado e o da casa de Krajcberg, uma grande e Mobilliada piramidé construlca proxil contrastam com as construçōes uniformes, $\theta$ o Centro Vivencial ganhará dimensão, a pan ir dos próximos anos, com a implantaçăo do res. colóńla para os pescadores, áreas de recreação Quando Krajcherg voltar de Paris - onde expóe num museu da Fundaçãa do Louvre - traré
consigo 15 pintores franceses que se instalarăo' em Nova Viçosa para trabalhar com o artista: a e nas praias. $\theta$ a fonte de inspiraçẵo, a natureza.
Todas essas perspectivas de abertura cultural us diárias custam 45 cruzelros e se pode comer dellciosas moquecas de pelxe. Habltada basicamente por pescadores, há alguns anos procidade para comprar barato na secular igrelinha matriz vallosas imagens be madeița, esculpidas - Nunca imaginel os tempos de hoje, conlessa D. Otila Acgusta, 73 anos, qua sempre arada e beia mascom malores posslbillidades de futuro do que nos meus tempos de moça, quando aqui existiam apenas algumas cabanas e gente sem trabalho. prometem mudar radicaimente Nova Viçosa -
Nova planificacão turistica para a região nordestina Uma planiflcaçăa turistica de viagem do Sul - Minas Ge-
global - que analisa a reglāo rais, Guanabara, Săo Paulo e

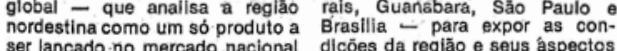
e Internacional do turisimo - está sendo feita para os Estados da Bahia, Sergipe, Alagoas. Per-
nambuco, Paraiba, Rio Grande do Norte, Ceará, Maranhão o Piaul,
envớvendo não só à Sudene (que de dados turisticos la lantamentc Seplan (Secretaria de Plane te, explica que uma das metas amento da Presidêncla da Re- Moura Cavalcantl pública) e o Banco do Nordeste. Com caracteristicas mais ou Porto de Suape, próximo a Re-
menos uniformes (praias, clima olfe, que tem uma paisagen troplcal, foiclore rico, artesanato multo rica, pralas de rochedo variado, sitema de rodovia $\theta$ um areia e pesca, a reglấo de Suape blilzado) a reglăo nordestina - siderada a mais agradánel con considerada uma reglấo turística tado, terá grande desenvolvimer por exceléncla - terá, a partir to. Ao lado disto; a empresa vem mo visando criar invesitimentos gião; , criar novos empregos
(segundo Bonald, cada quarto de hotel gera trés empregos diretos e
novos indiretos), atender à redis tribulção de renda proposta pelo PND e Sudene flxar o homem terra. Planejamos: desenvolver atividades paralelas às atraçóe naturais de Pernambuco, incengeral. O turista em geral vai procura de pralas e comidas tiine atividades paralelas que aumentem seu tempo de pe ele receba, consequentemente. nossa cultura. segundo Olim dois anos -
Semana Crioula em Bagé comeca hoje PORTO ALEGRE (O GLOBO) - COM Uma pro-

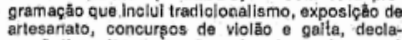

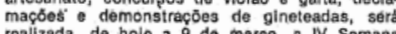

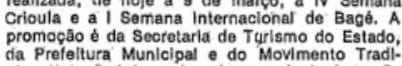
oionallsta Gaúcho, edeverá ser a principal atraçắ deste mess na tronteira ga cora cia cozinha gaúcha, Aemonistraçzes de pealo, laços apresentaçăo de dangas.

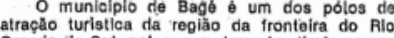

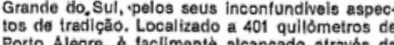

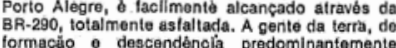

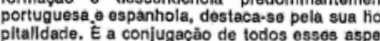

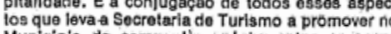

\section{Guzeliro Maritimo SEMACIA SATTA}

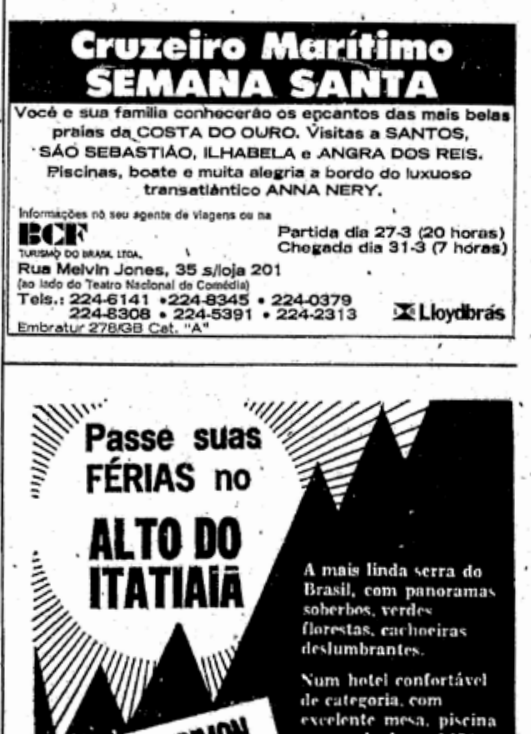


Scliar, Carlos Vergara, Vera Brandt, entre outros.

Desses artistas, Krajcberg foi o que mais se empenhou em transformar a cidade em um "paraíso para a arte e o lazer", conforme descrito pelo jornal O Globo em março de 1975. Kracjberg e Zanine queriam transformar Nova Viçosa em um importante centro de cultura do Nordeste, e, para isso, fariam no local uma escola livre de Arte e Arquitetura. Segundo depoimento de Teodório, o crítico de arte francês Pierre Restany $^{6}$ foi a Nova Viçosa, a convite de Karjcberg, e lá pensaram em montar uma escola de tapeçaria:

Antes [de Zanine] era uma vilazinha de pescadores, onde ele sonhava ter uma escola de artes usando a madeira, usando a palha, usando coco, usando a concha e as pessoas produzindo algo que embelezasse as casas desse país afora. Eu me lembro que esteve aqui com o Krajcherg, na época, um crítico de arte, o Pierre Restany, e o projeto dele, que nasceu na cabeça dele com o Krajcberg aqui, era de montar aqui uma tapeçaria. Mas como tudo depende do poder político, para assistir, para criar situações, para oferecer vantagens e tudo mais, instalação, o projeto não criou. Não sei por quê. Então hoje Nova Viçosa é o que está aí. (CARDOSO, depoimento de 17/08/2017)

Ainda de acordo com Cardoso (17/08/2017), as 12 glebas que Zanine recebeu como pagamento pelo projeto urbanístico não estão desenhadas no seu projeto urbanístico, mas podemos localizá-las na imagem de satélite (f.36). Começam um pouco antes do atual loteamento Caminhos de Abrolhos e vão até o loteamento Costa do Atlântico. Não foi possível encontrar o nome dos donos das 12 glebas, mas entre eles estavam, de acordo com Teodório, Delza, esposa de Zanine na época, Chico Buarque, Sergio Machado, Susana, sogra de Zanine, Oscar Niemeyer, Baby Bocayuva, sendo que a 5 era do próprio Zanine e a 6 de Krajcberg. Do lote 1 até o lote 6 passava o antigo riacho Sambacuí, que formava uma lagoa no lote 1, onde, esporadicamente, desembocava no mar. O próprio Teodório era o responsável por criar condições mínimas para a área se tornar habitável:

Eu trabalhei como chefe do escritório dele, eu administrava as obras nessas propriedades que ele tinha com os amigos e ali a gente plantava o coqueiro, a barraca, o posto para fornecer água

6 Pierre Restany (24 de junbo de 1930 a 29 de maio de 2003) fazia parte do movimento Nouveau Realisme. O grupo incluia Martial Raysse, Arman, Yves Klein, François Dufrene, Raymond Hains, Daniel Spoerri, Jean Tinguely, Jacques Villeglé. Posteriormente os artistas César, Mimmo Rotella, Niki de Saint Phalle e Christo juntaram-se ao grupo. Ele também era editor da revista Domus em 1963, fazendo viagens recorrentes a Milão. Em 1969, ele foi um dos curadores da Bienal de São Paulo. Junto a Krajcberg escreveu um manifesto chamado: Manifeste Du Naturalisme Integrále Manifesto do Naturalismo Integral. 


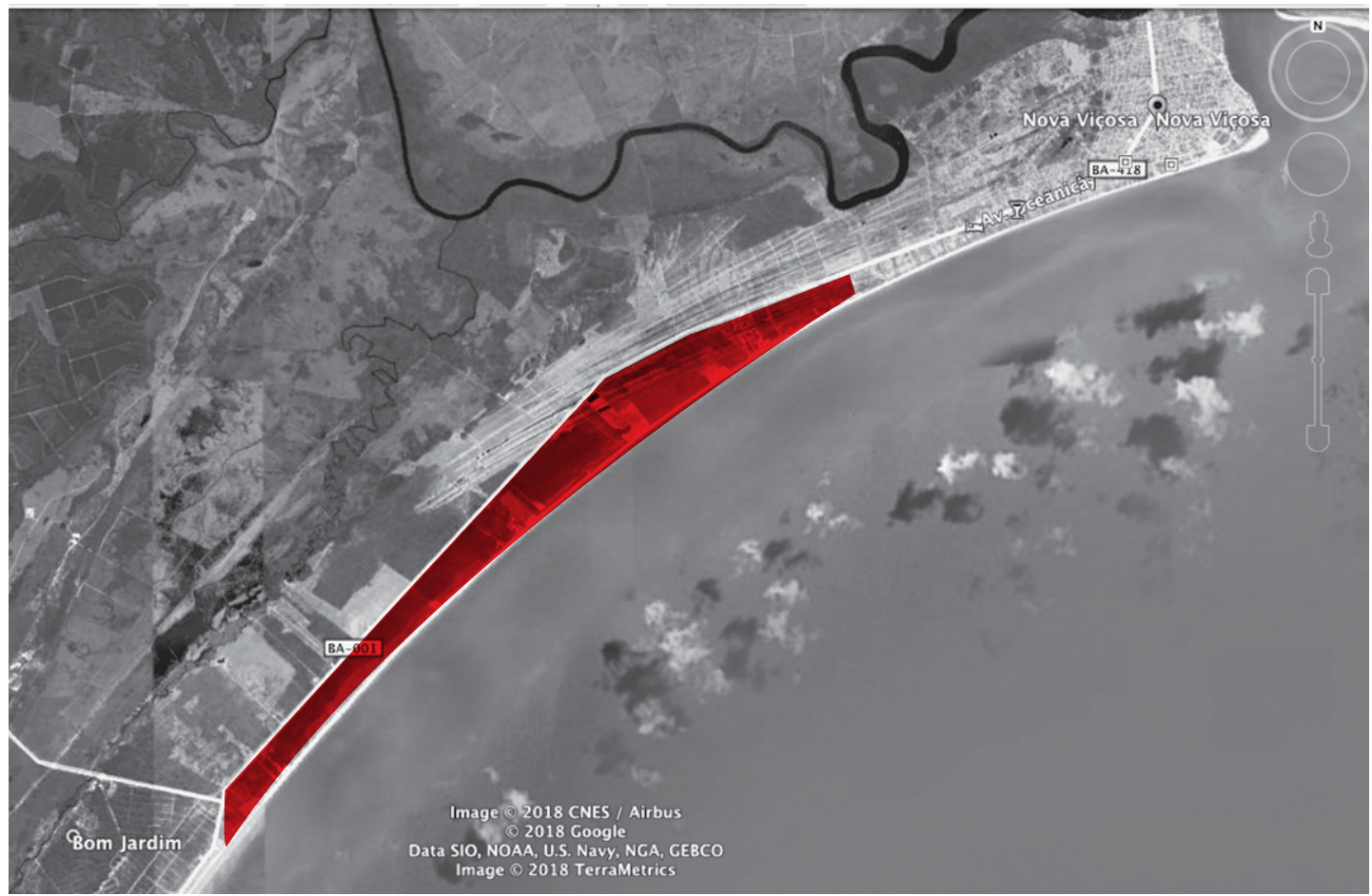

Figura 36. Área que Zanine recebeu, em troca do projeto urbanístico para Nova Viçosa. Fonte: google maps.

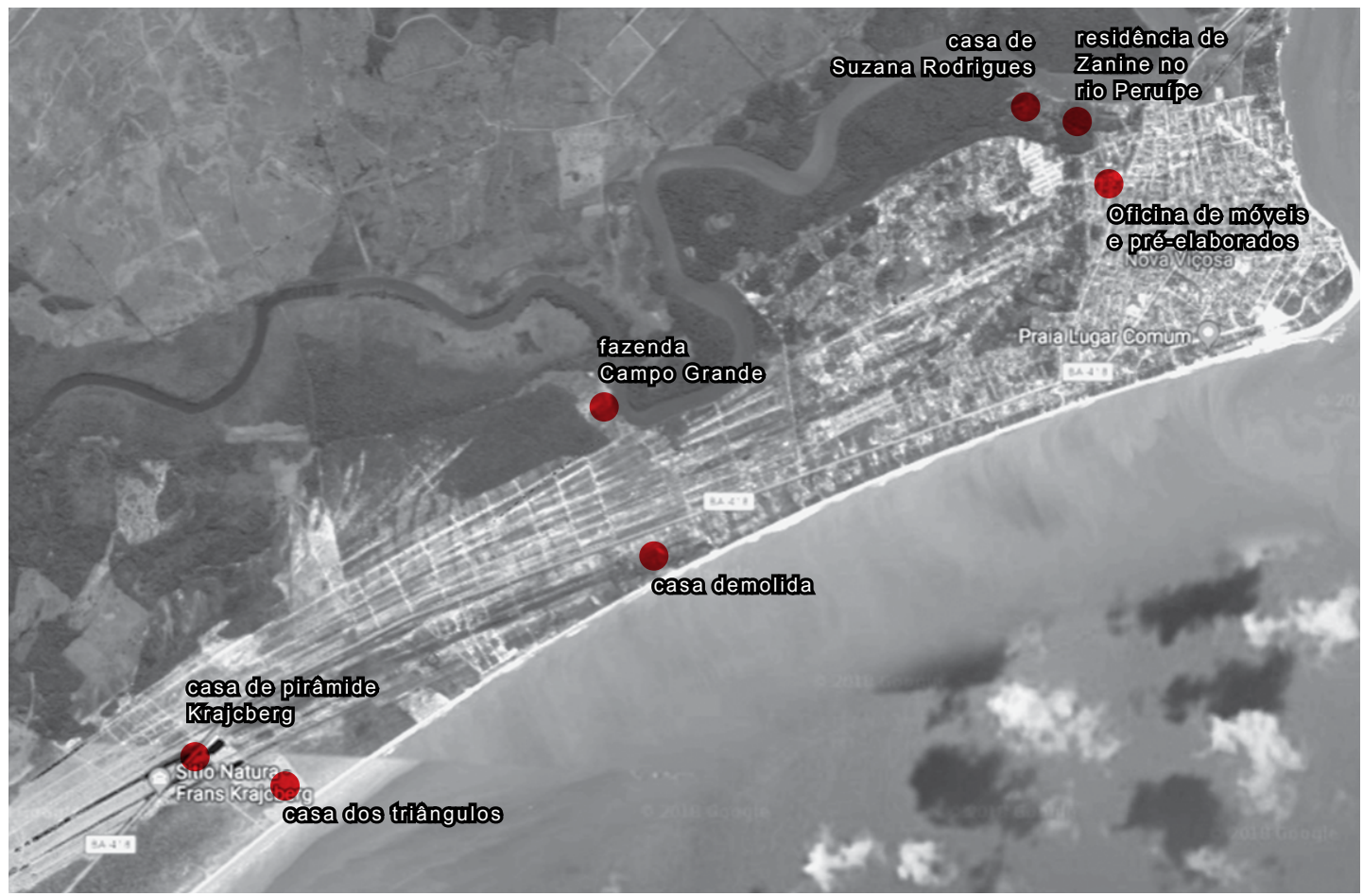

Figura 37. Localização de alguma das obras feitas por Zanine em Nova Viçosa. Fonte: Google maps. 
para eles e ali se fazia uma pequena agricultura aproveitando o que tinha de árvores naturais. Mas, então o Zanine era uma pessoa que impunba muito respeito, critério, ele impunba assim muito valor, ele valoriza as pessoas. Se ele chegava perto de um artesão ou de uma pessoa comum, ele sentava, perguntava e queria saber. Ele valorizava o que ele aprendeu com as pessoas. Ele dimensionou esse universo. Acho que ele é um homem sábio e que ele soube aplicar isso a Nova Viçosa. Então Nova Viçosa deve muito a ele e se isso fosse ensinado nas escolas, mostrado nas escolas, talvez fosse um referencial para gerações futuras, não só aqui, mas nesse país imenso, conhecer o Zanine. (CARDOSO, depoimento de 17/08/2017)

Das casas que Zanine executou em Nova Viçosa (f.37), 2 ainda existem. Algumas foram levadas pelas águas, como a casa da Vera Brandt, levada pelo mar, e a do próprio Zanine, levada pelo Rio Peruípe. Outras foram demolidas. 


\section{obras na cidade}

Aqui trataremos das casas feitas em Nova Viçosa. Acredita-se que existiram outras residências além das descritas abaixo, mas o número é impreciso. Por isso, decidiu-se estudar apenas obras das quais temos imagens ou resquícios de construção.

\section{Casa dos Triângulos (f.38)}

Em 1970, Zanine construiu para si a famosa Casa dos Triângulos. Ficava no lote 5 , em uma grande terreno em frente ao mar. Segundo Cardoso (depoimento de 17/08/2017), o primeiro trabalho para o qual foi contratado foi o de abrir o poço para captação de água para esse terreno, o que era fácil pois com pouca profundidade já se encontrava água potável. Depois disso, plantaram vários coqueiros no terreno e pés de caju trazidos por Zanine de outras regiões (de uma espécie que produz muito e dá frutos grandes).

Nessa mesma época, Zanine construía sua fábrica e sua Casa no Rio. As idas da casa de praia para a Casa no Rio não eram tão simples como nos dias atuais, em que podemos fazer o percurso pela Avenida Oceânica, asfaltada. O caminho era feito através de estradas de terra e areia e ainda não havia postes de eletricidade nas glebas, que eram muito afastadas do centro.

Dessa casa só restam fotografias, além da plantação de coqueiros feita por Zanine.

\section{Ateliê Krajcberg (Casa de Pirâmide, f.40 e f.41)}

Em 1971 foi feito o ateliê e residência de Krajcberg, no lote 6. Sua implantação é próxima ao mar. O mesmo trabalho de abertura de poço foi feito para essa gleba.

Essas duas residências, a de Zanine e a de Krajcberg, tinham formatos geométricos inovadores para a época, o que fez com que o jornal O Globo fizesse uma matéria dizendo: 


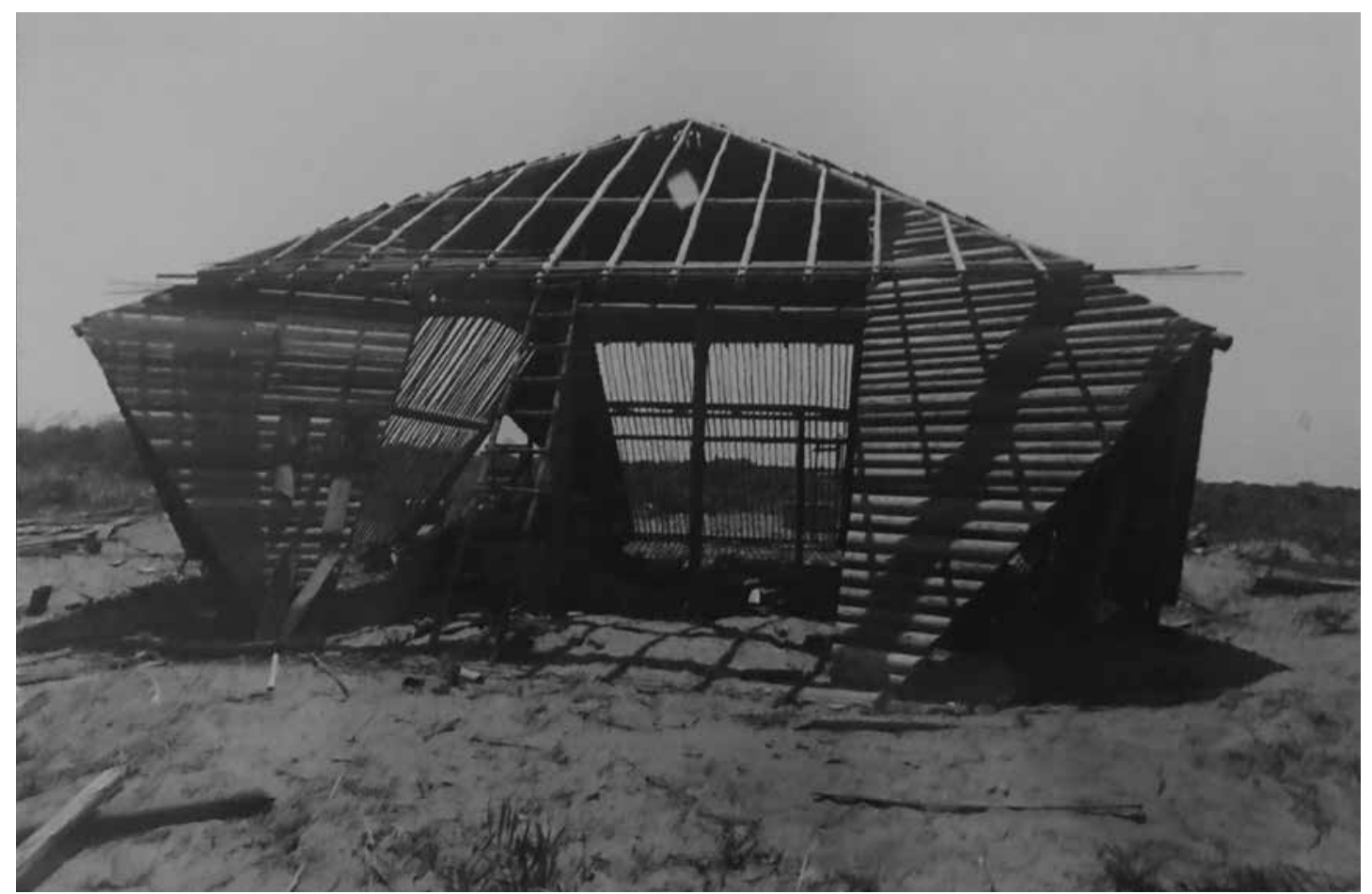

Figura 38. Casa dos triângulos, no lote 5, de Zanine. Fonte: acervo pessoal de Déa de Zanine.

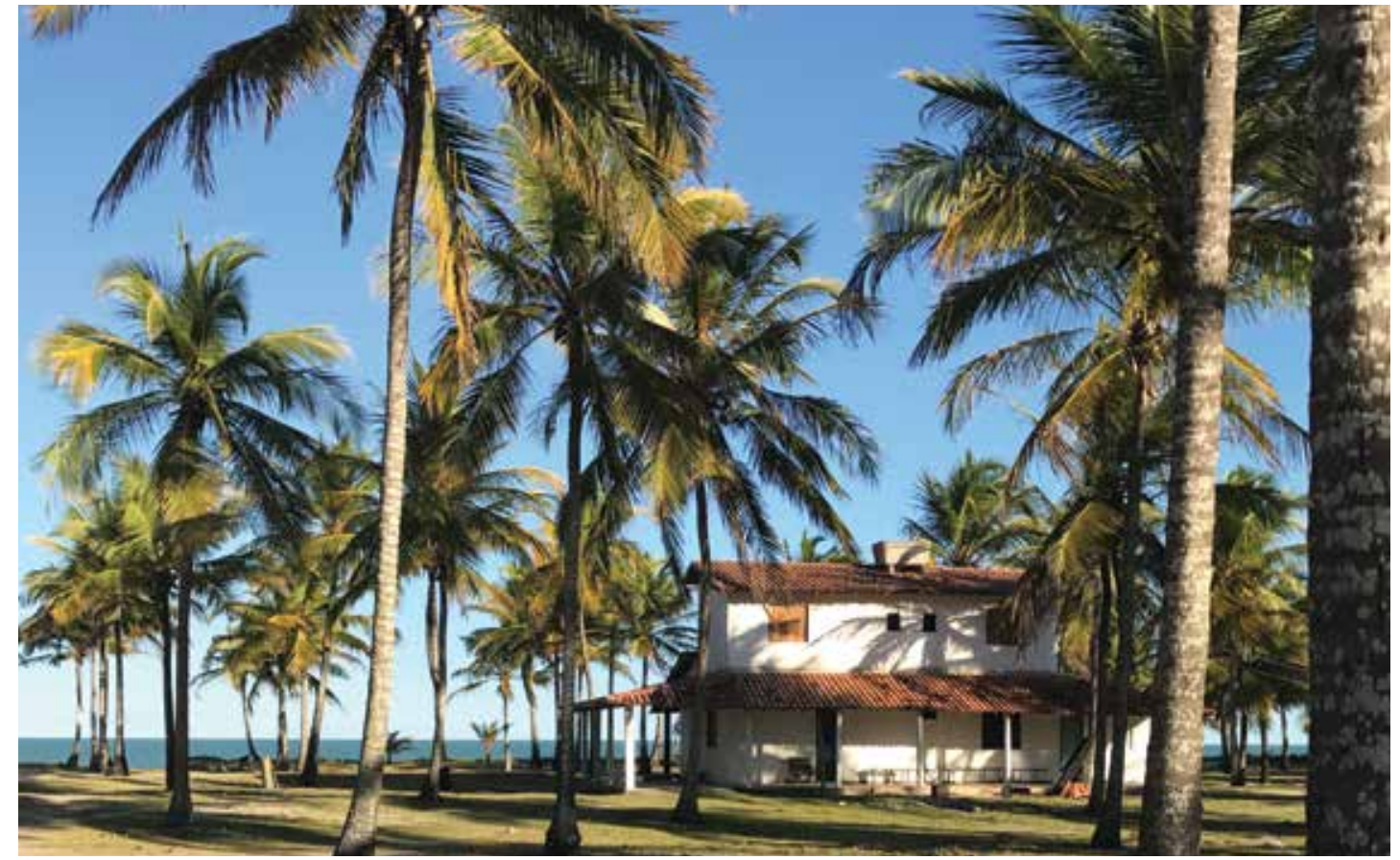

Figura 39. Atual residência no lote 5, pode-se ver a plantação de coqueiros feita por Zanine. Fonte: Amanda Carvalho. 


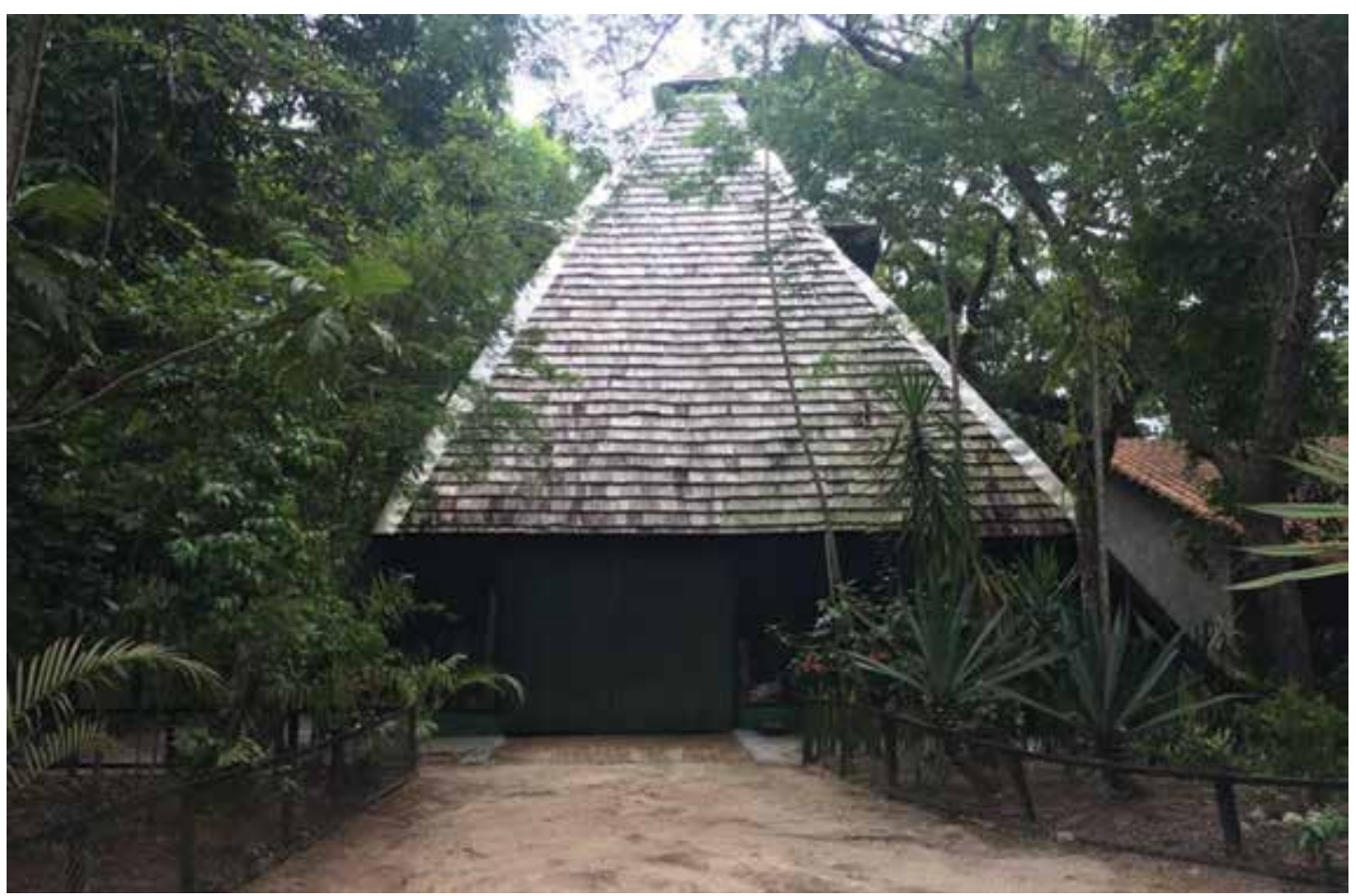

Figura 40. Casa de Pirâmite, no lote 6. Fonte: Kátia Gondo.

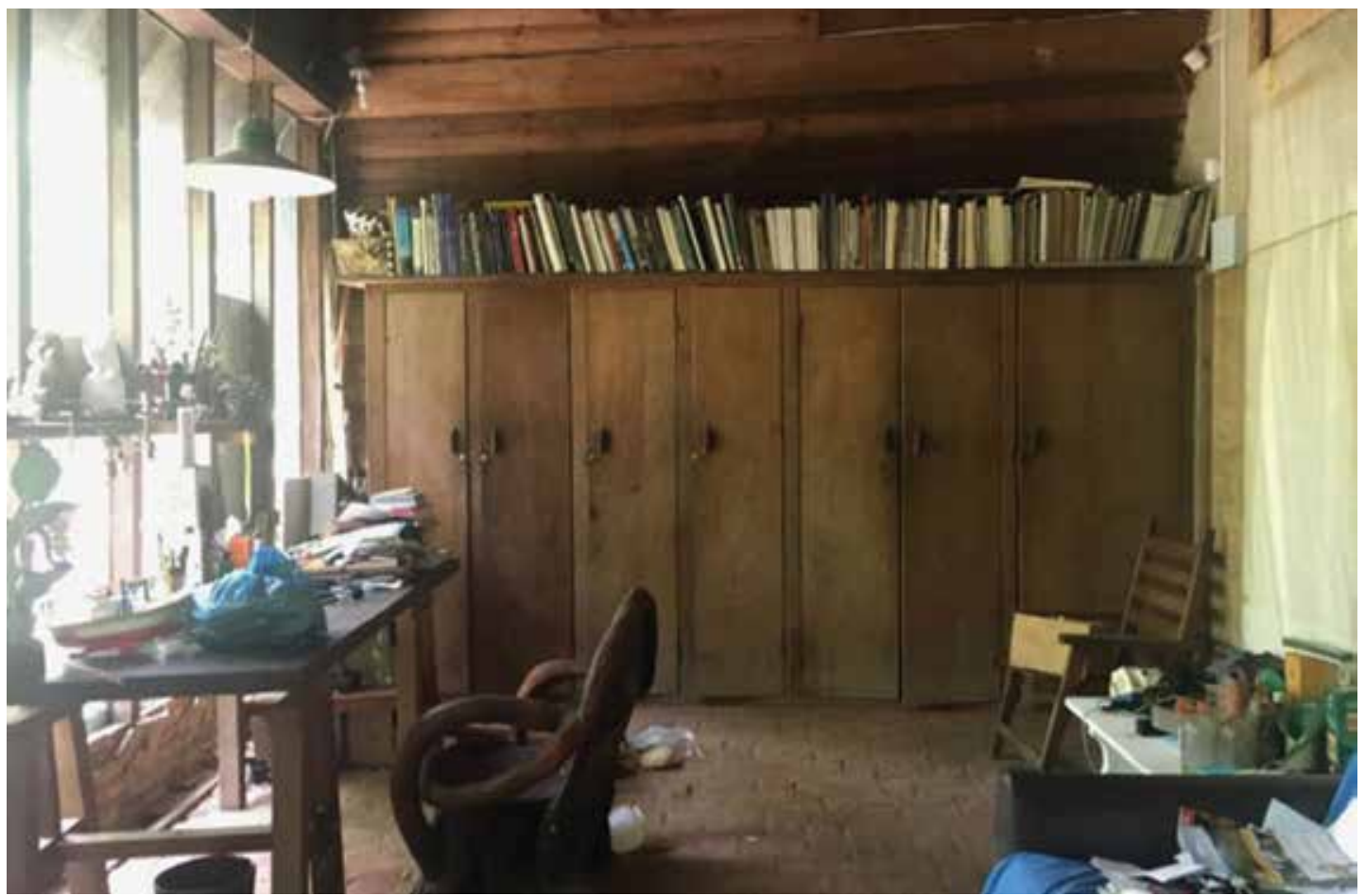

Figura 41. Interior da casa de Pirâmite, no lote 6. Vista do ateliê, no térreo. Fonte: Kátia vvv. 
As casas do Centro Vivencial de Nova Viçosa possuem, à primeira vista, muita semelhança com as construções que geralmente aparecem em filmes de fiçãa científica. O desenho mais sofisticado é o da casa de Krajcberg, uma grande e majestosa pirâmide construida próxima ao mar. Mobiliadas com móveis de estilo antigo, as casas contrastam com as construcões uniformes e pobres da cidadezinha. (O GLOBO, 5/03/1975, p. 5)

A casa de pirâmide ainda existe mas não é mais usada como residência de Krajcberg, e sim como seu ateliê. A atual residência de Krajcberg é conhecida como "casa na árvore" e fica elevada do solo. Diferentemente do que muitos pensam, não é projeto de Zanine, mas de Waldemar Guerra. Também conhecido como Demar Guerra, este cursava a faculdade de jornalismo quando chegou a Nova Viçosa para fazer uma matéria sobre a recém inaugurada BR 101. Sabendo que Zanine estava no local, decidiu conhecê-lo e foi convencido pelo mesmo a ficar em Nova Viçosa.

Assim como a casa de Krajcberg, há muitas outras construções em madeira na cidade, feitas por pessoas que trabalharam com Zanine, que ao olhar descuidado podem se passar por casas do mesmo.

\section{Fazenda Campo Grande (f.42, f.43, f.44, f.45, f.46)}

Em 1968 foi projetada uma residência para a antiga Fazenda Campo Grande, atual loteamento Caminho de Abrolhos. O proprietário da fazenda era Moacir Martins da Silva, que a vendeu para Jedydia Worckam, conhecido como Diduxe, que foi quem encomendou a residência a Zanine.

A casa passou por muitos donos, sofrendo diversas alterações. Foi ampliada com a construção de uma área maior para quartos. Essa área era ligada à sala da residência. Posteriormente também foi feita uma edícula.

Zanine sempre pensa a implantação de suas residências de forma a estabelecer uma relação com o lugar, com a natureza. Esta casa foi implantada com sua fachada voltada para o Rio Peruípe.

Infelizmente não foi possível entrar na residência, pois estava fechada, mas pela janela da sala pode-se ver que grande parte dos móveis são de Zanine. A casa necessita de manutenção, com fissuras na estrutura do telhado, telhas e vidros quebrados que demonstram pouco uso da mesma.

\section{Casa de Suzana Rodrigues (f.47, f.48, f.49, f.50, f.51, f.52)}

Esta casa foi feita para Suzana Rodrigues, mãe de Teresa Cristina, segunda esposa de Zanine a morar em Nova Viçosa. De acordo com depoimento de Teodório, ela foi construída entre os anos de 1974 e 1975. 


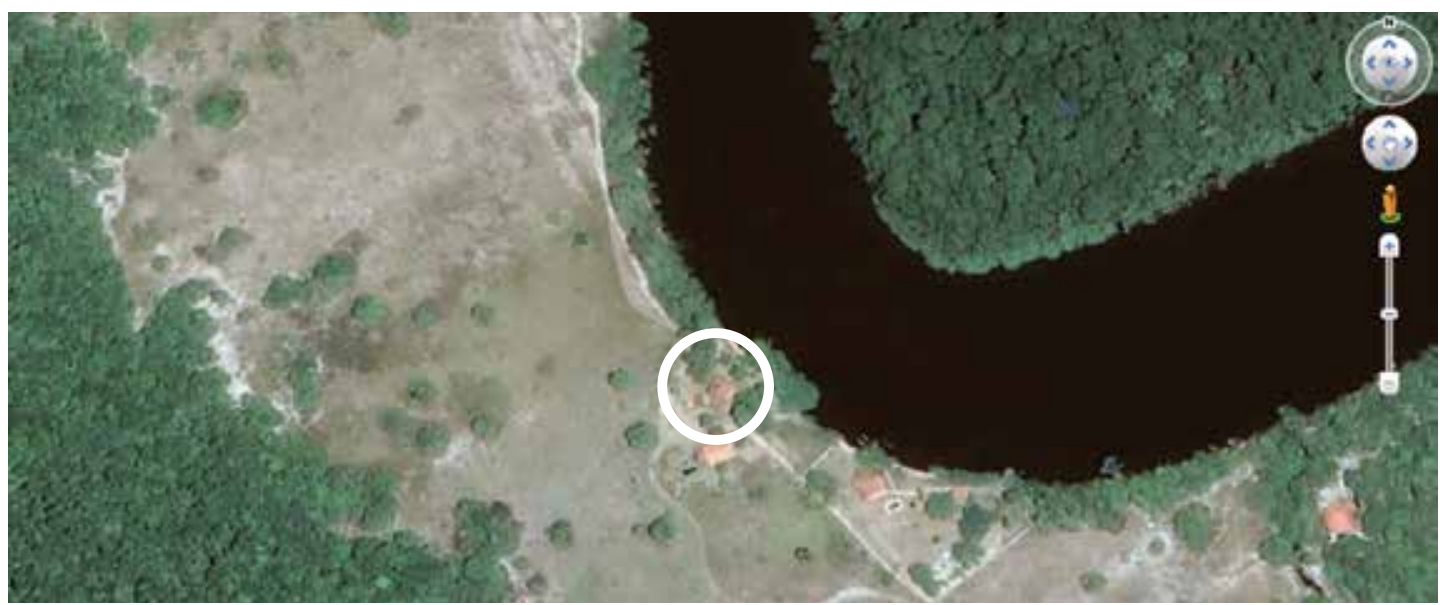

Figura 42. Localização da residência de Zanine na Faženda Campo Grande. Fonte: Google maps.

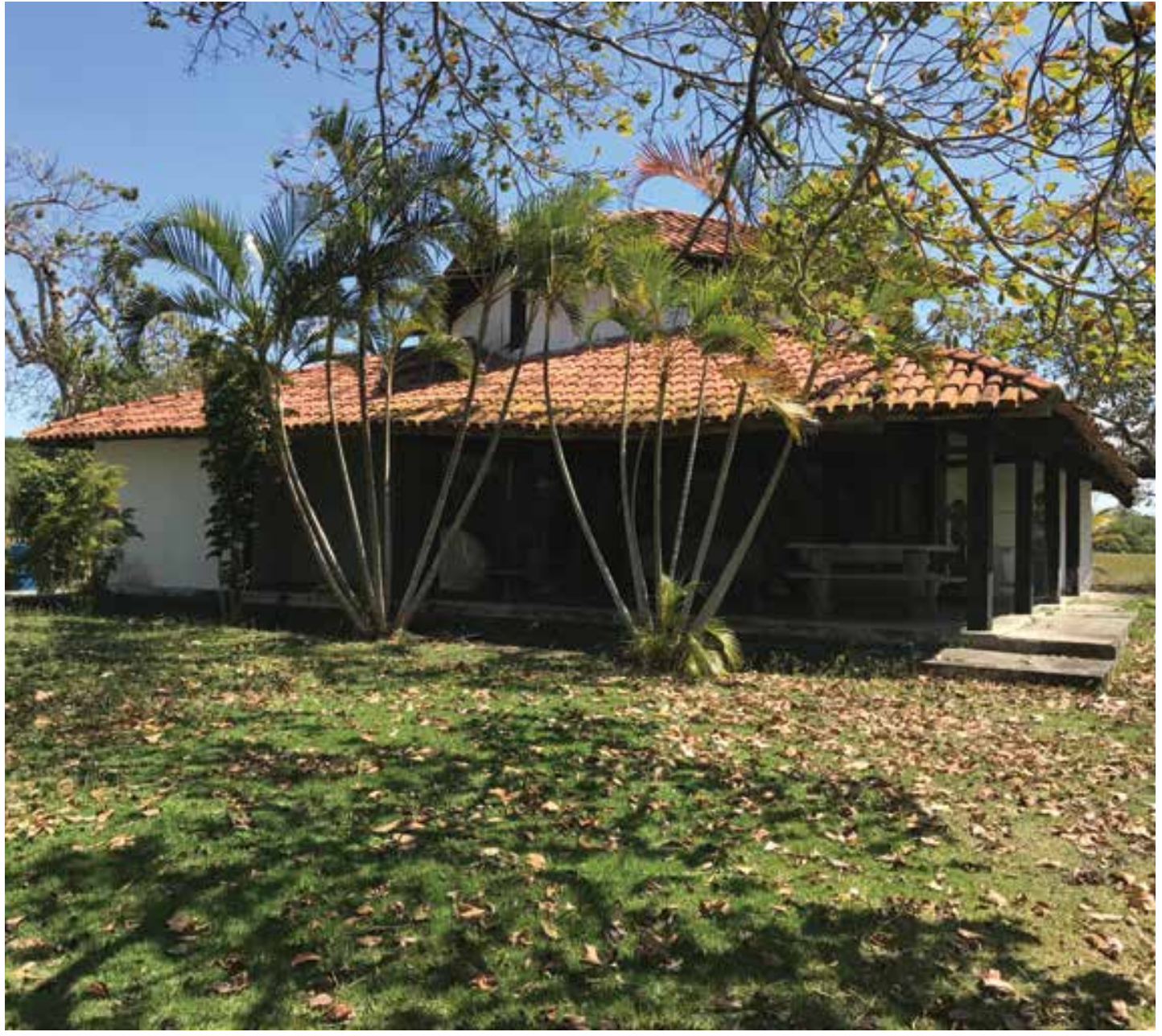

Figura 43. Fachada da residência localizada na Faženda Campo Grande. Fonte: Amanda Carvalho. 

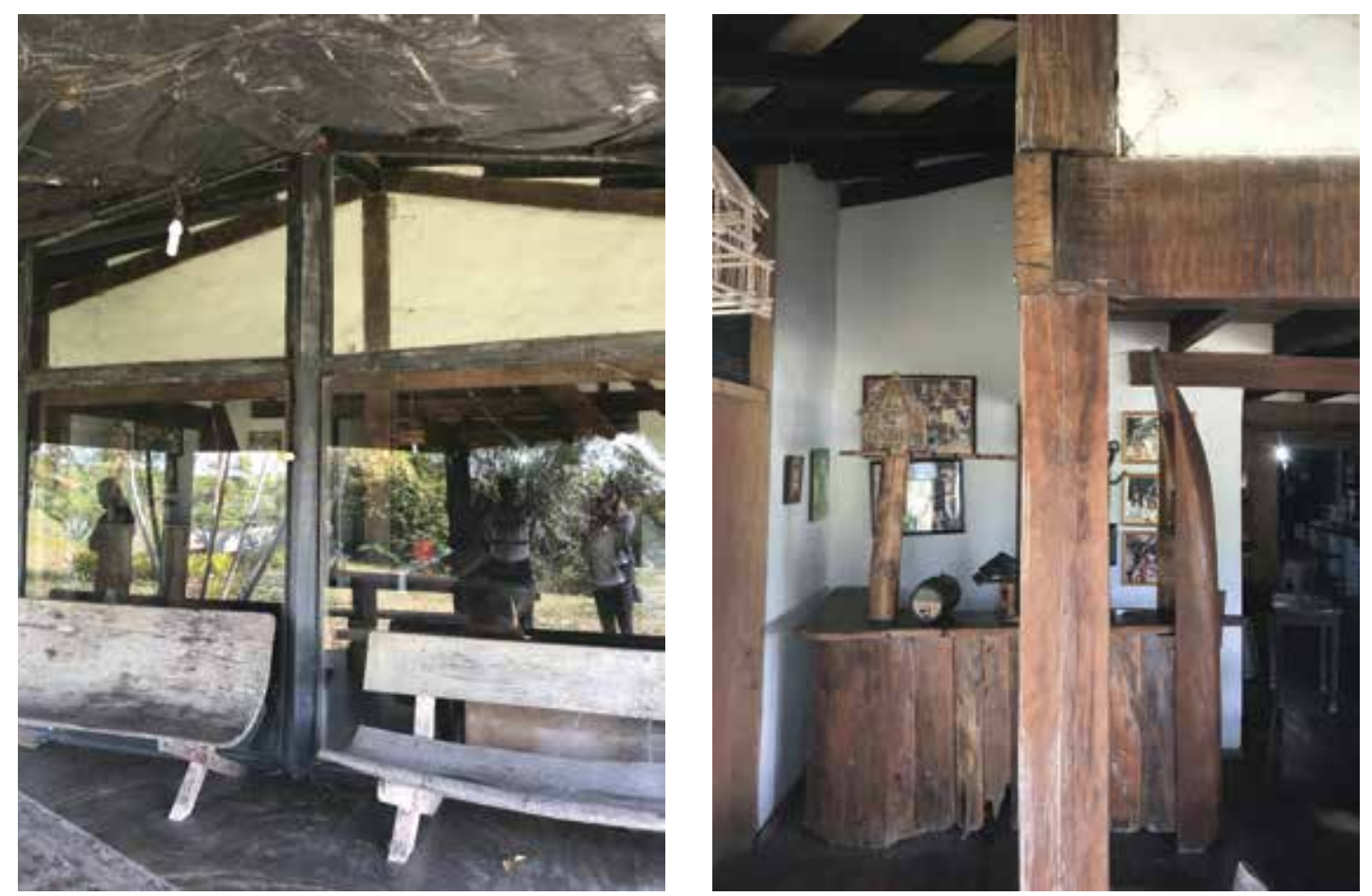

Figuras 44 e 45. Atual estado de conservação da residência situada na faẓenda Campo Grande. Fonte: Amanda Carvalho

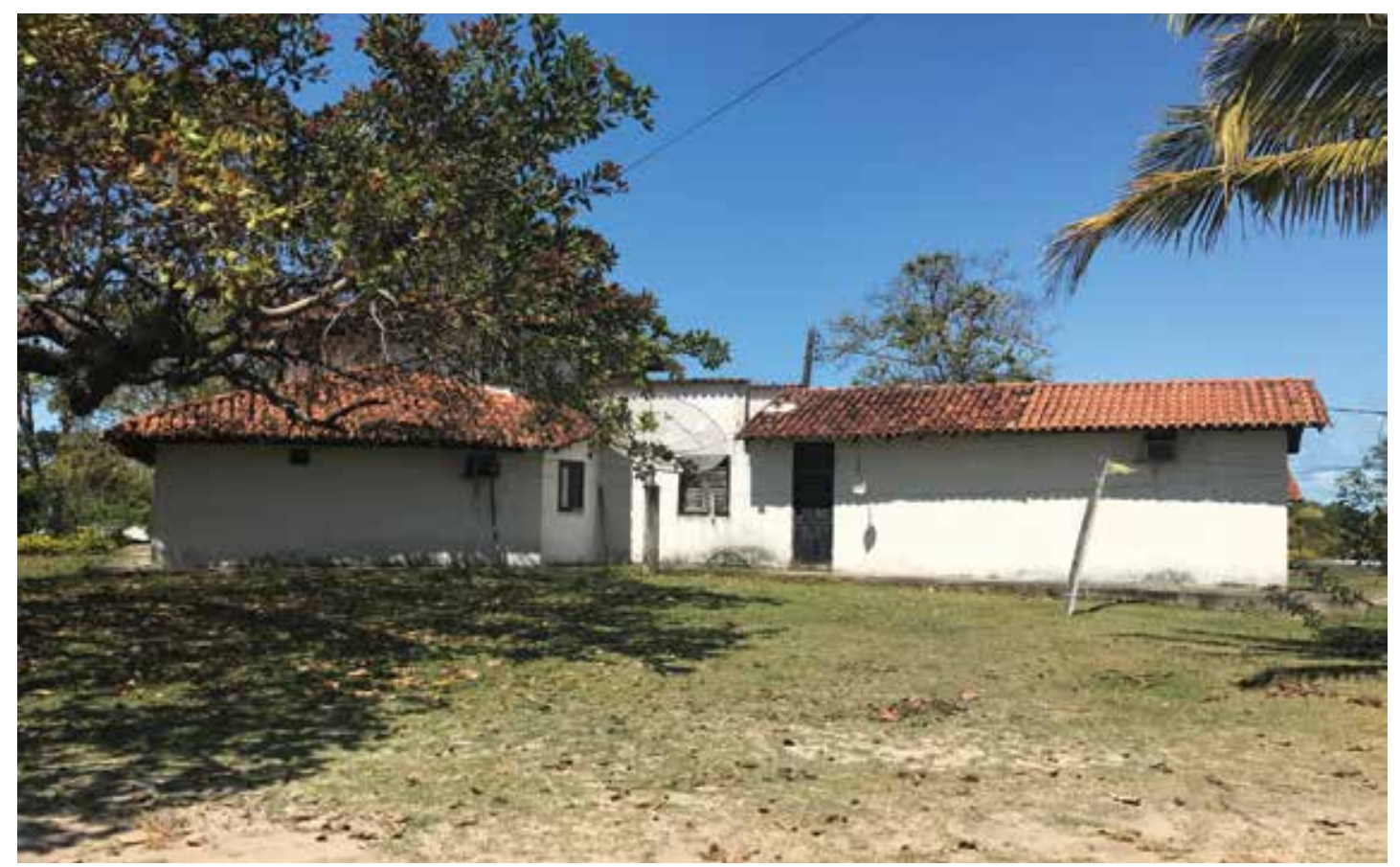

Figura 46. Retângulo de quartos anexado à casa, feito posteriormente. Fonte: Amanda Carvalho. 
Atualmente a casa é de Luiz Pavão Filho, conhecido na cidade como Pavãozinho, e passou por reformas que alteraram o acabamento da mesma. $\mathrm{O}$ teto, antes de madeira, hoje é de PVC branco. O piso, que era de ladrilhos quadrados de cerâmica vermelha, hoje é de porcelanato. Apesar destas modificações, o layout da casa é original.No térreo temos a sala de estar, com um grande painel de vidro enquadrando o Rio Peruípe, a sala de jantar e a cozinha. No primeiro andar encontram-se os quartos.

\section{Residência de Zanine no Rio Peruípe (f.53 e f.54)}

Ao lado da casa de Suzana Rodrigues ficava a casa de Zanine, beirando o Rio Peruípe, projetada em 1970. Era muito bonita, descrita por todos como um grande painel de vidro que pousava sobre as águas, pois toda a casa estava em balanço, avançando sobre o rio. Zanine chegava à cidade pelo aeroporto de Caravelas e tinha uma lancha para buscalo, deixando-o debaixo da sua residência, onde, por uma escada, subia até a sala.

Infelizmente, com o passar dos anos e o abandono da residência, houve um desbarrancamento na região, que a levou. Hoje resta apenas parte da fundação da mesma, além de poucos registros fotográficos e de histórias sobre um lindo bosque que ficava no terreno da casa.

\section{Casa demolida (f.55 e f.56)}

Esta casa ficava no lote 2 e foi demolida entre 2016 e 2017. Estava em bom estado e não se sabe ao certo o motivo pelo qual foi demolida. Provavelmente para lotear e vender o terreno, como ocorre em todo o litoral de Nova Viçosa.

A falta de conhecimento sobre as casas feitas por Zanine em Nova Viçosa, somada ao pequeno reconhecimento da contribuição da obra de Zanine para a arquitetura brasileira, tanto pelas escolas de arquitetura, quando pelos órgãos de patrimônio histórico, podem resultar no desaparecimento das suas casas. Atualmente as poucas residências que restaram em Nova Viçosa estão em condições físicas muito ruins, com enorme falta de manutenção.

\section{Oficina de Zanine (f.57, f.58, f.59, f.60, f.61)}

Após aceitação pela burguesia do Rio de Janeiro dos móveis feitos na Elecunha, Zanine decidiu construir o seu próprio galpão, ampliando a fabricação dos móveis denúncia e construindo uma área para fabricação de estruturas de madeira para casas.

De acordo com depoimentos dos funcionários que trabalharam com Zanine em Nova Viçosa, a área da fábrica era composta pelo escritório e por três galpões: um onde 
Figuras 47 e 48. Casa de

Suzana Rodrigues. Fonte:

Amanda Carvalho.
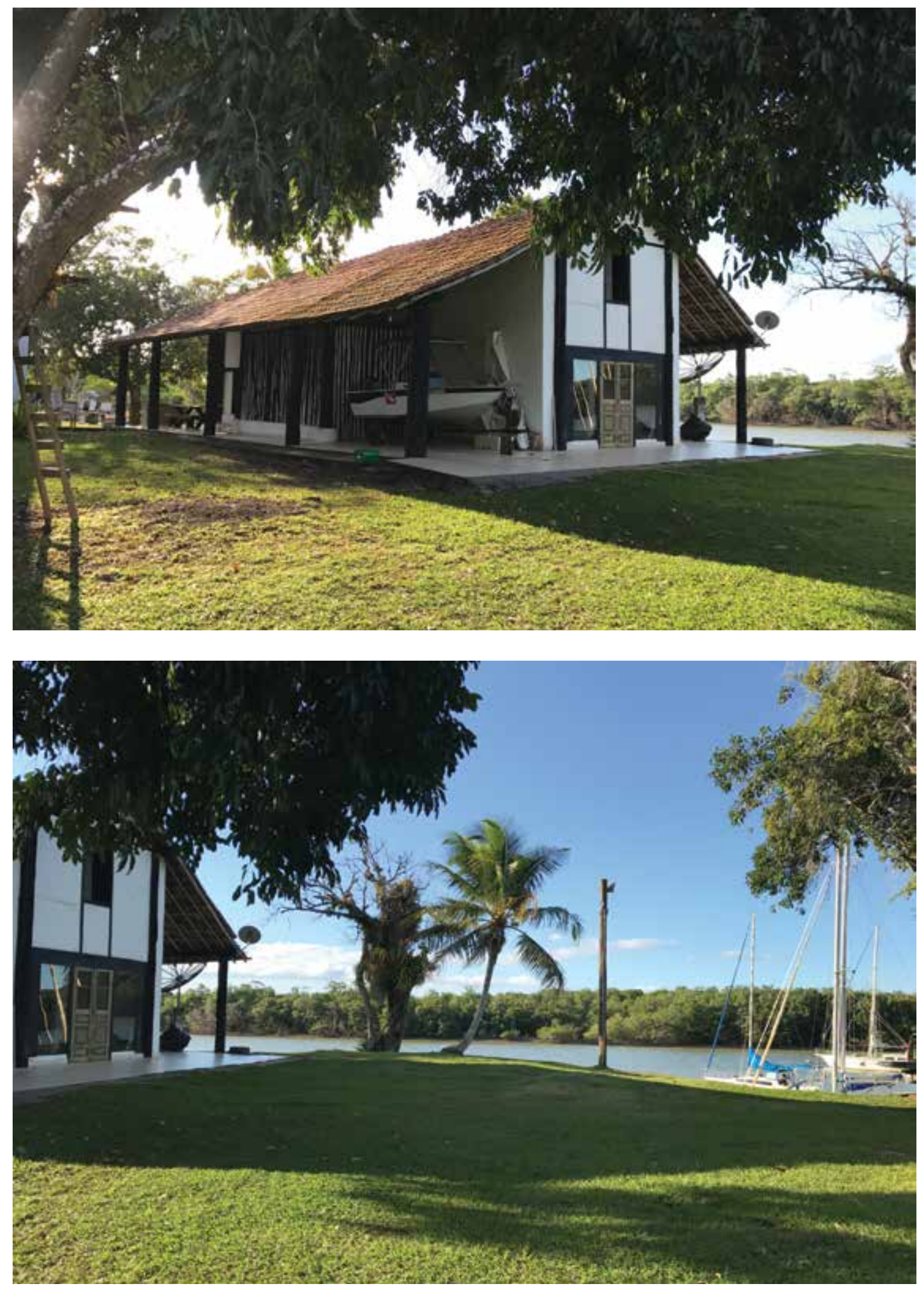
Figura 49. Casa de Suzana

Rodrigues. Fonte: Amanda

Carvalho.

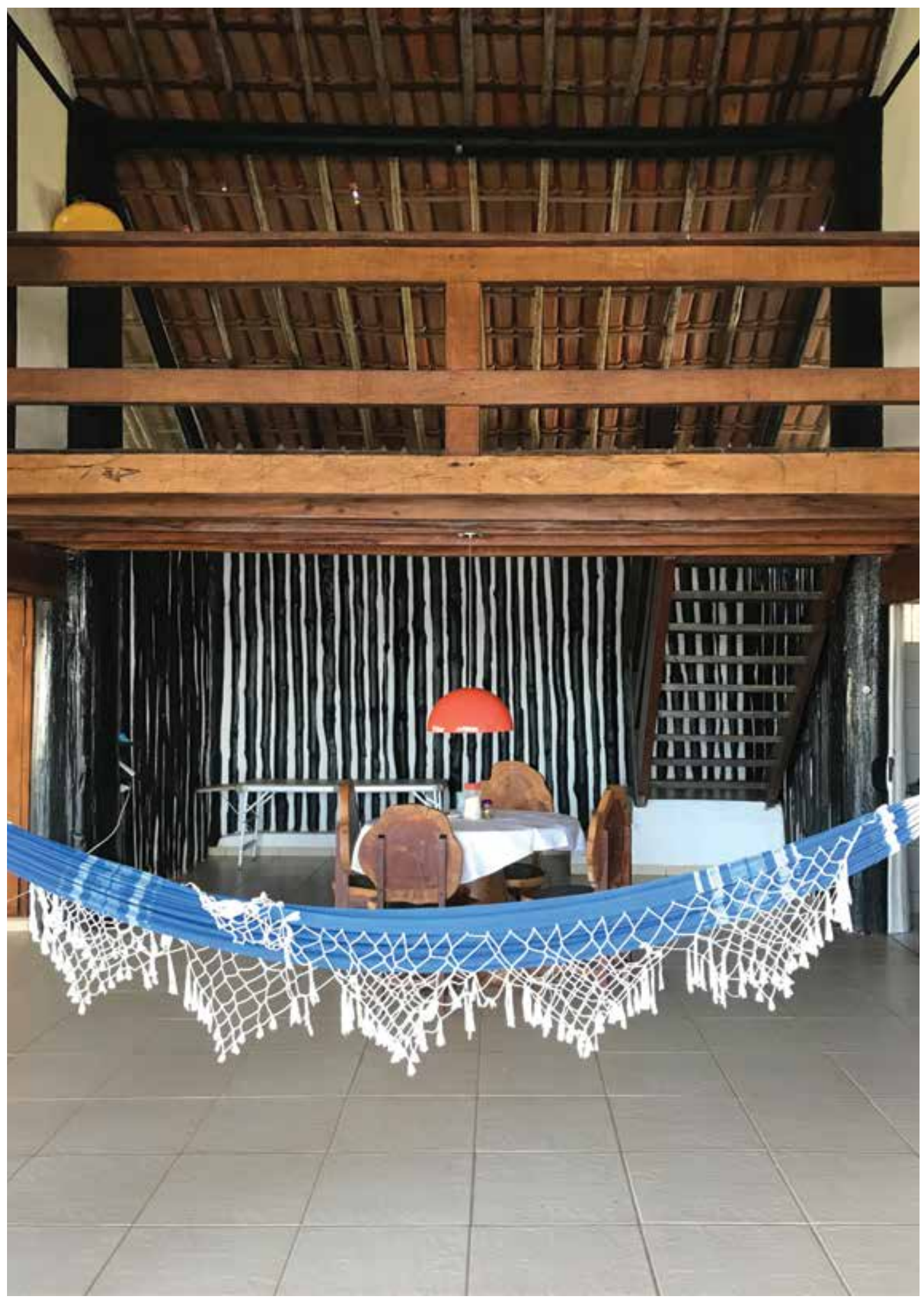


Figuras 50 e 51. Casa de

Surana Rodrigues.Fonte:

Amanda Carvalho.
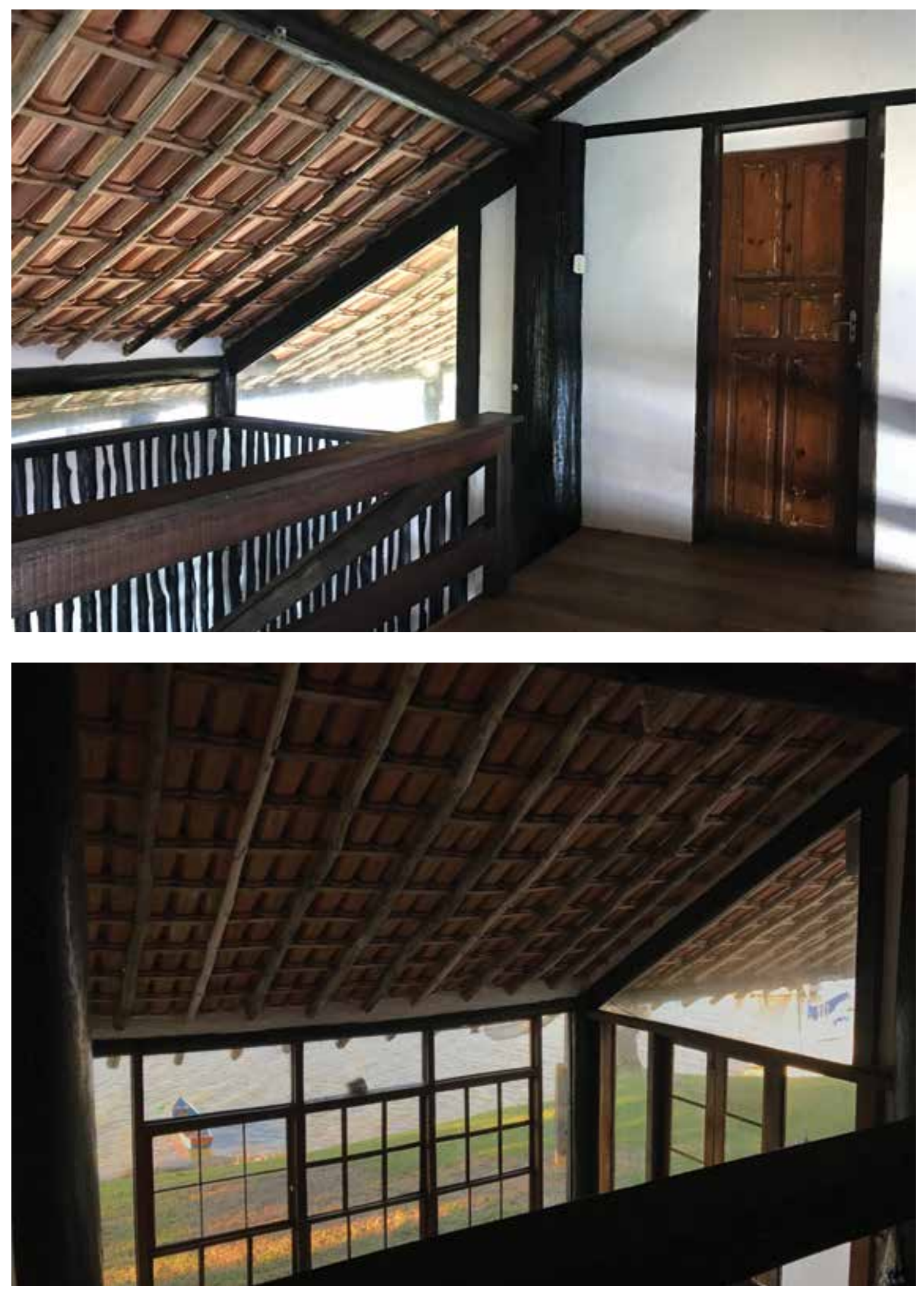
Figura 52. Casa de Suzana

Rodrigues.Fonte: Amanda

Carvalho.

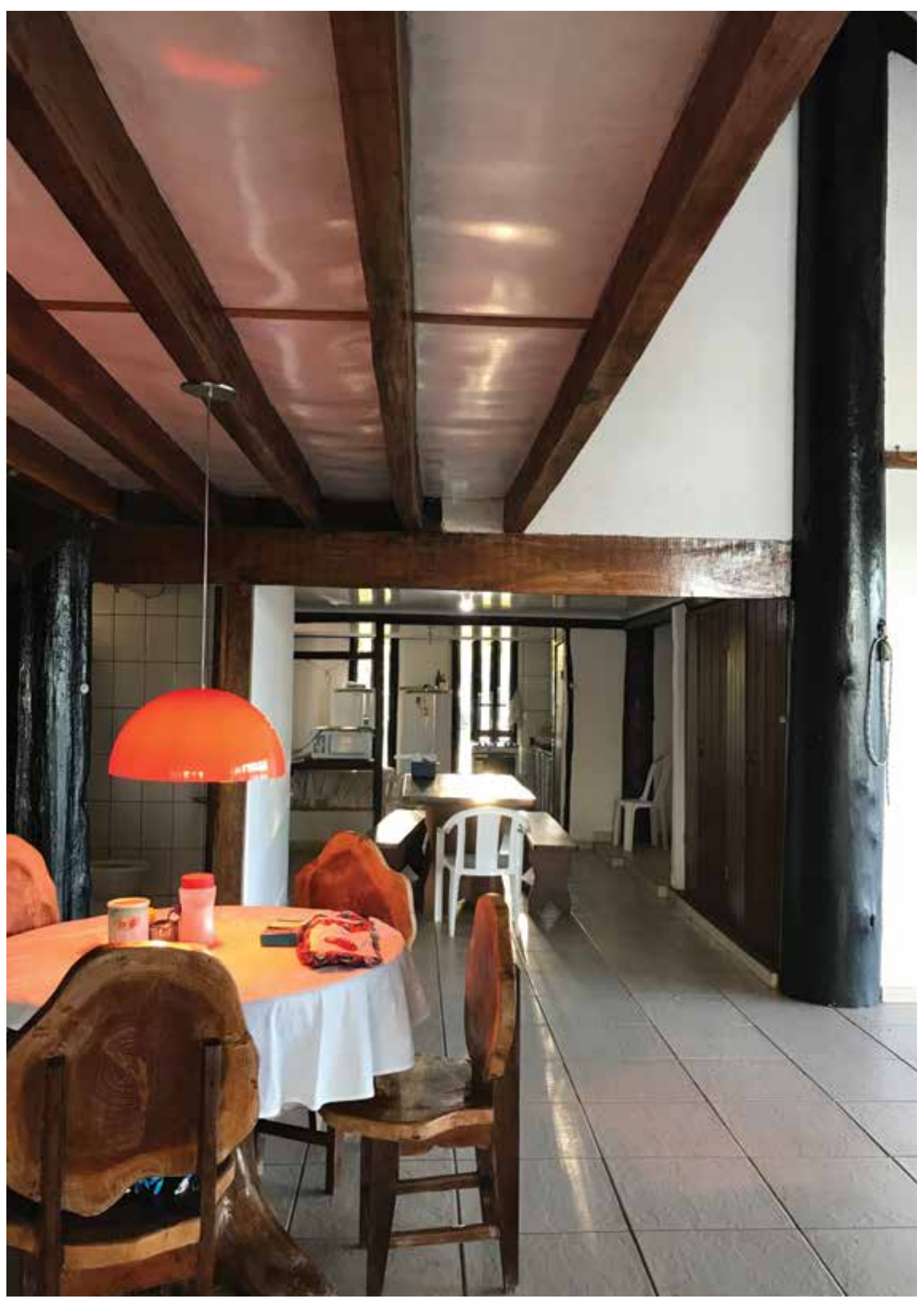




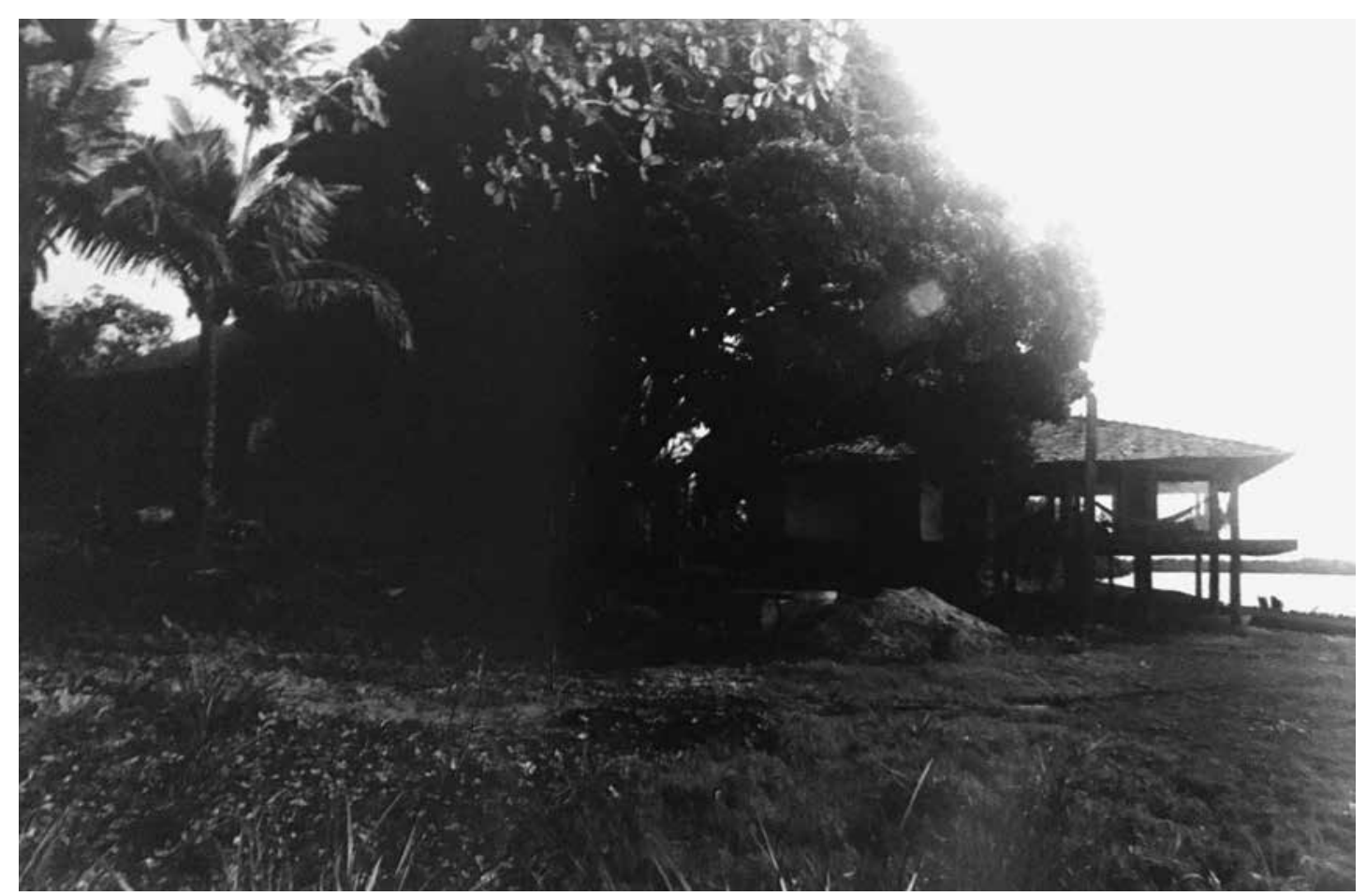

Figura 53. Casa de Zanine no Rio Peruípe. Fonte: acervo pessoal de Déa de Zanine.

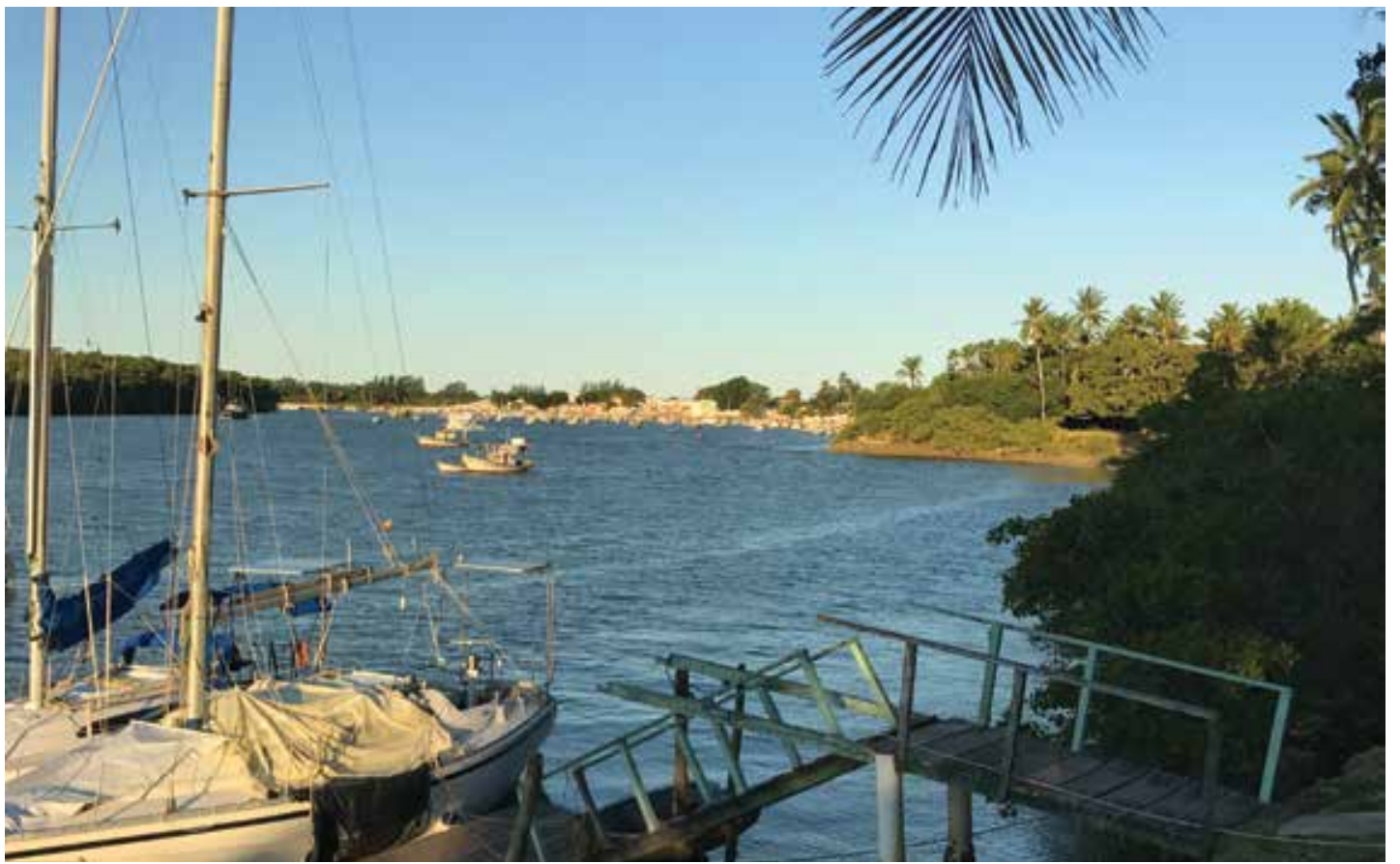

Figura 54. Foto tirada da casa de Suzana Rodriguês, olhando para o local aonde ficava a casa de Zanine na beira do Rio Peruipe. Fonte: Amanda Carvalho. 

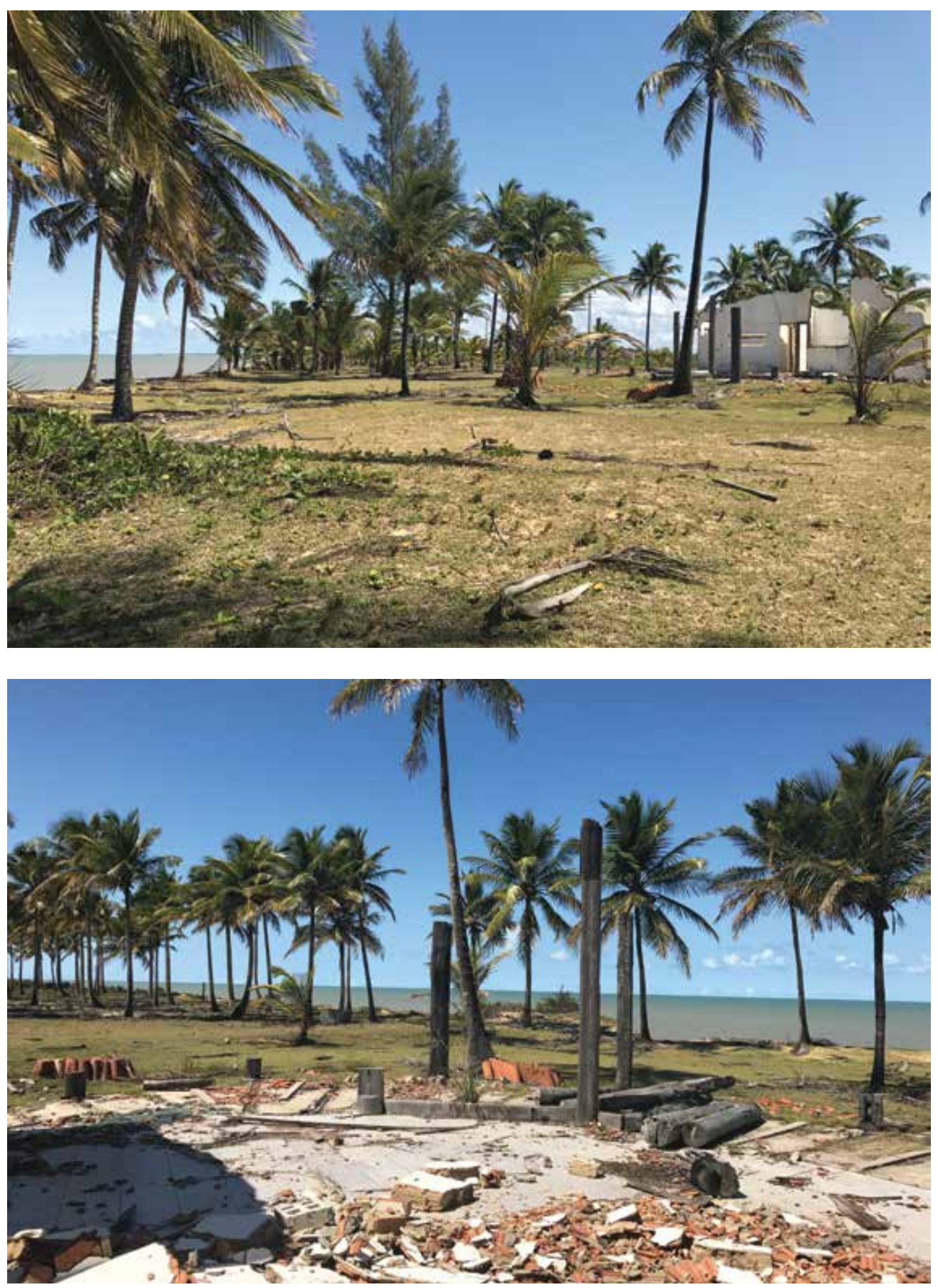

Figuras 55 e 56. Casa demolida, agosto de 2017. Fonte: Amanda Carvalho. 
montavam as casas, outro onde montavam os móveis, e um terceiro onde faziam portas e janelas. Além disso havia dois engenhos horizontais e área para secagem da madeira. Segundo Barros (depoimento de 19/08/2017), "Era um galpão, piso de cimento. Tinha dois engenhos horizontal, tinha tupia, tinha circular, traçador, tudo tinha. Mas o resto era tudo manual. Era enchó goiva, enchó de duas mãos, plaina, tudo certinho. Tinha desempeno também".

A partir de conversa com os carpinteiros pode-se fazer o desenho ao lado, de implantação da fábrica. No número 1 ficava o escritório. Ainda há resquícios dessa construção. O número 3 é o galpão dos móveis, o 2 o almoxarifado e o 4 onde afiavam as ferramentas. O número 5 era o galpão de construção das estruturas das casas. Ele tinha aproximadamente $30 \mathrm{~m}$ x $15 \mathrm{~m}$. O número 6 é o galpão de construção de portas e janelas e o número 7 são os engenhos horizontais.

O galpão dos móveis era em estrutura de madeira, piso de cimento, coberto com telhas e completamente aberto nas laterais, com exceção do espaço do almoxarifado. Nele ficava a área reservada para afiação dos instrumentos. As ferramentas desse galpão eram: motosserra, para tirar fatias do tronco, e várias ferramentas manuais.

As áreas reservadas para construção das casas e das portas e janelas também não tinham vedação lateral, apenas uma estrutura de madeira coberta com telha. O piso era de cimento. As ferramentas do galpão para construção das portas e janelas eram: tupia, duas serras de fita, desengrosso, desempeno e furadeira de bancada. No galpão de construção de casas ficavam: a motoserra, a parafusadeira, o enxó e a serra manual. $\mathrm{Na}$ construção das casas usavam os engenhos horizontais, que ficavam numa área coberta e reservada apenas para os mesmos, para tirarem as tábuas a partir do tronco da madeira. Até hoje existem as bases dos engenhos, sendo possível identificar onde ficavam.

O escritório era um sobrado pequeno, construção que ainda existe, apesar de muito modificada. Atualmente é usado como residência de uma família, após a ocupação irregular de toda a área onde ficava a fábrica de Zanine.

Segundo Tancredo, trabalhavam aproximadamente 10 pessoas dentro da fábrica, entre carpinteiros e arquitetos. Mas muita gente trabalhava fora da área de fabricação das casas e dos móveis, como secretárias, pessoas que cuidavam do almoxarifado, além dos que iam para a floresta, dos que faziam as fundações das casas nos lugares onde as mesmas seriam instaladas e da equipe de projetistas que ficava no Rio de Janeiro.

Entre os carpinteiros havia os que trabalhavam diretamente com as estruturas das casas e os que ficavam nos móveis. As formas de trabalho e as ferramentas necessárias para as duas áreas eram diferentes, mas, apesar dessa divisão, todos sabiam as técnicas de construção das estruturas das casas e dos móveis, de forma que, quando a demanda na construção de uma das áreas aumentava, todos se uniam.

Durante visita a Nova Viçosa, entrevistamos 4 trabalhadores da fábrica do Zanine: Tancredo, Benedito, Peu e Reinaldo.

Tancredo era o subencarregado da fábrica, um dos funcionários mais antigos; foi o responsável pela construção da fábrica. Ele sabia muito bem fazer a estrutura das casas, 


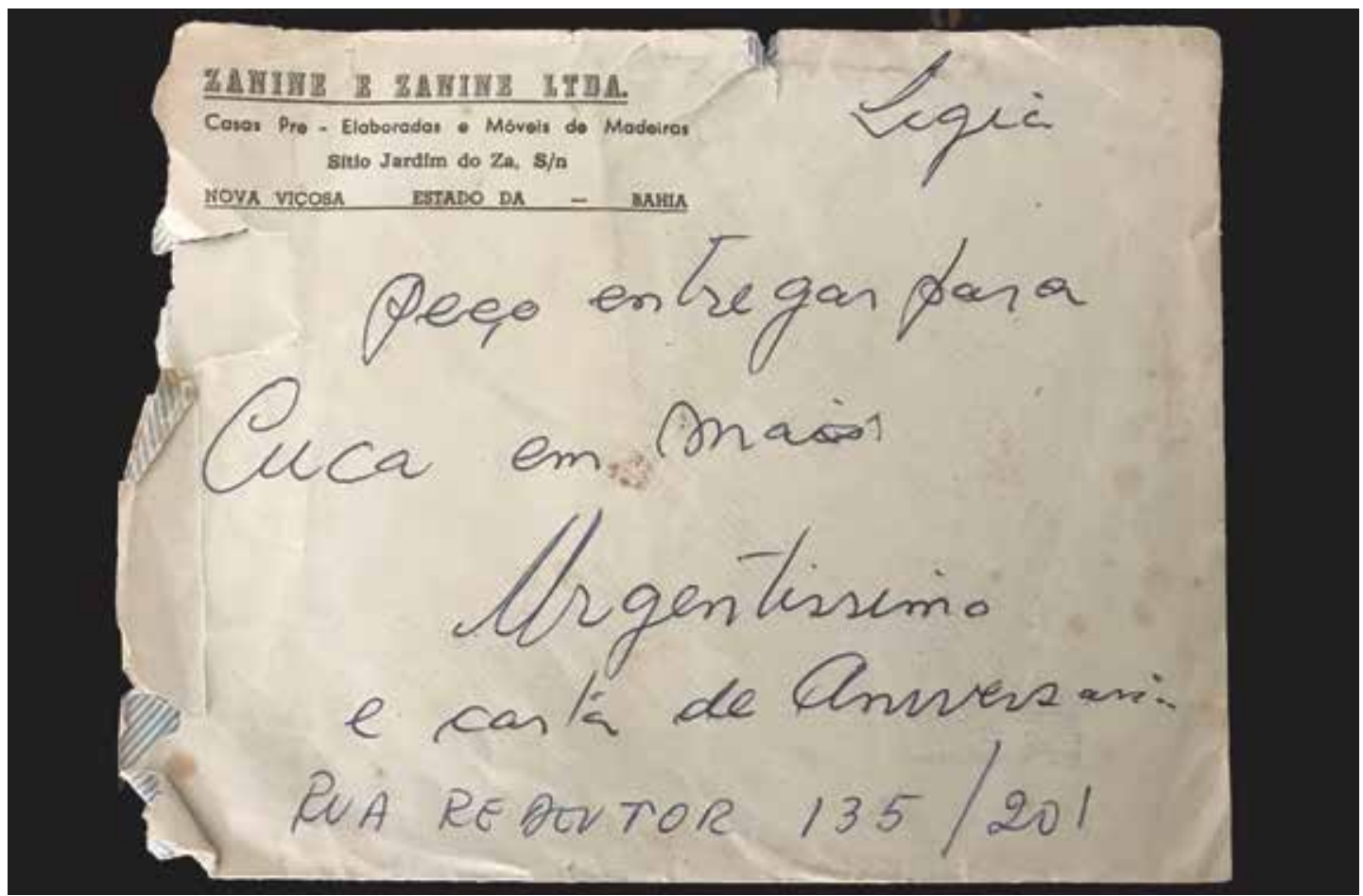

Figura 57. Envelope da oficina de Zanine, localizada no Sítio Jardim do Za. Fonte: acervo pessoal Déa de Zanine.

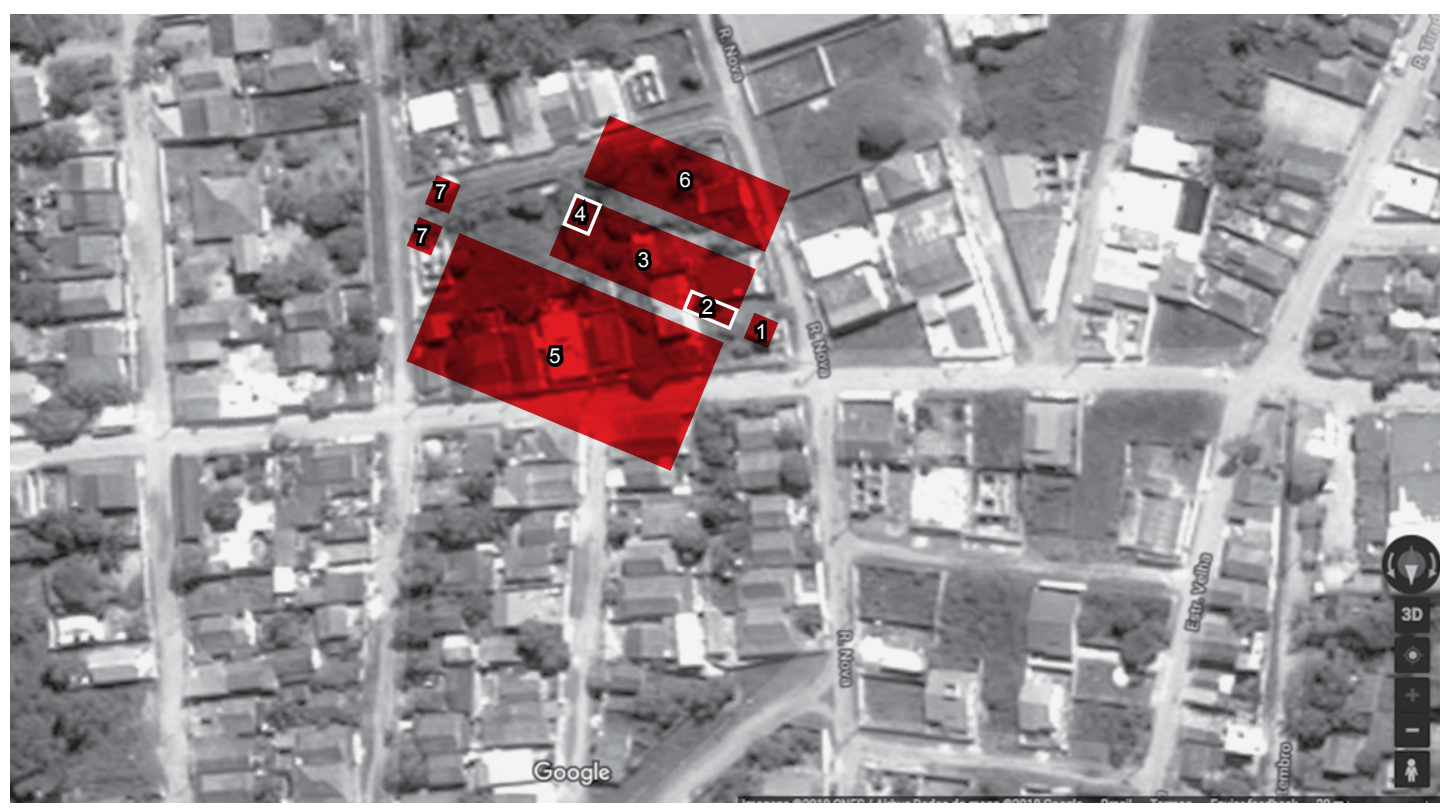

Figura 58. Implantação da oficina de Zanine feita a partir de conversas com os carpinteiros. 1 .

escritório; 2. almoxarifado; 3. galpão de móveis; 4. afiação ferramentas; 5. galpão de casas; 6. galpão de portas e janleas; 7. engenhos horizontais. 


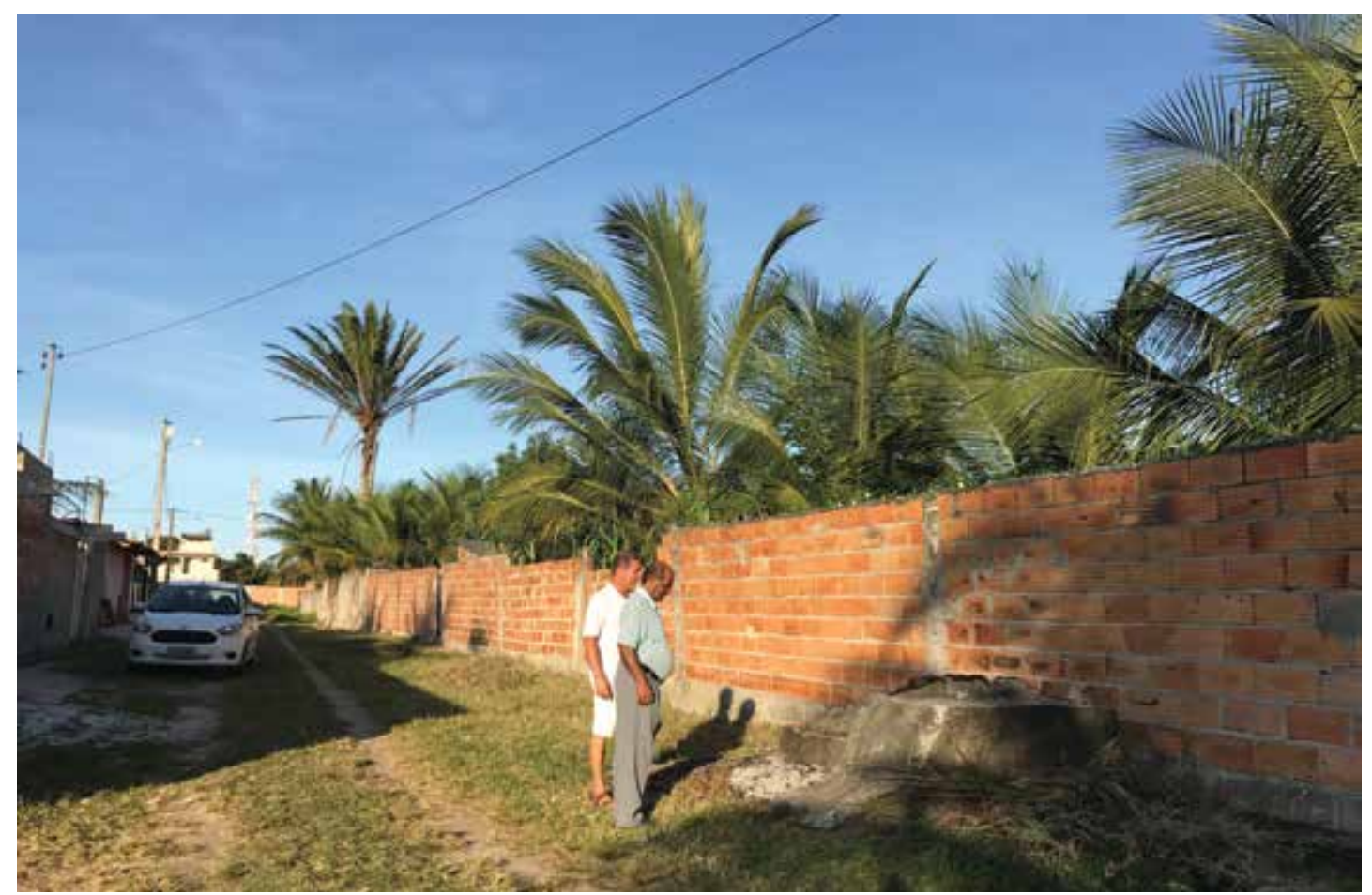

Figura 59. Fundação do engenho horizontal. Fonte: Amanda Carvalho.
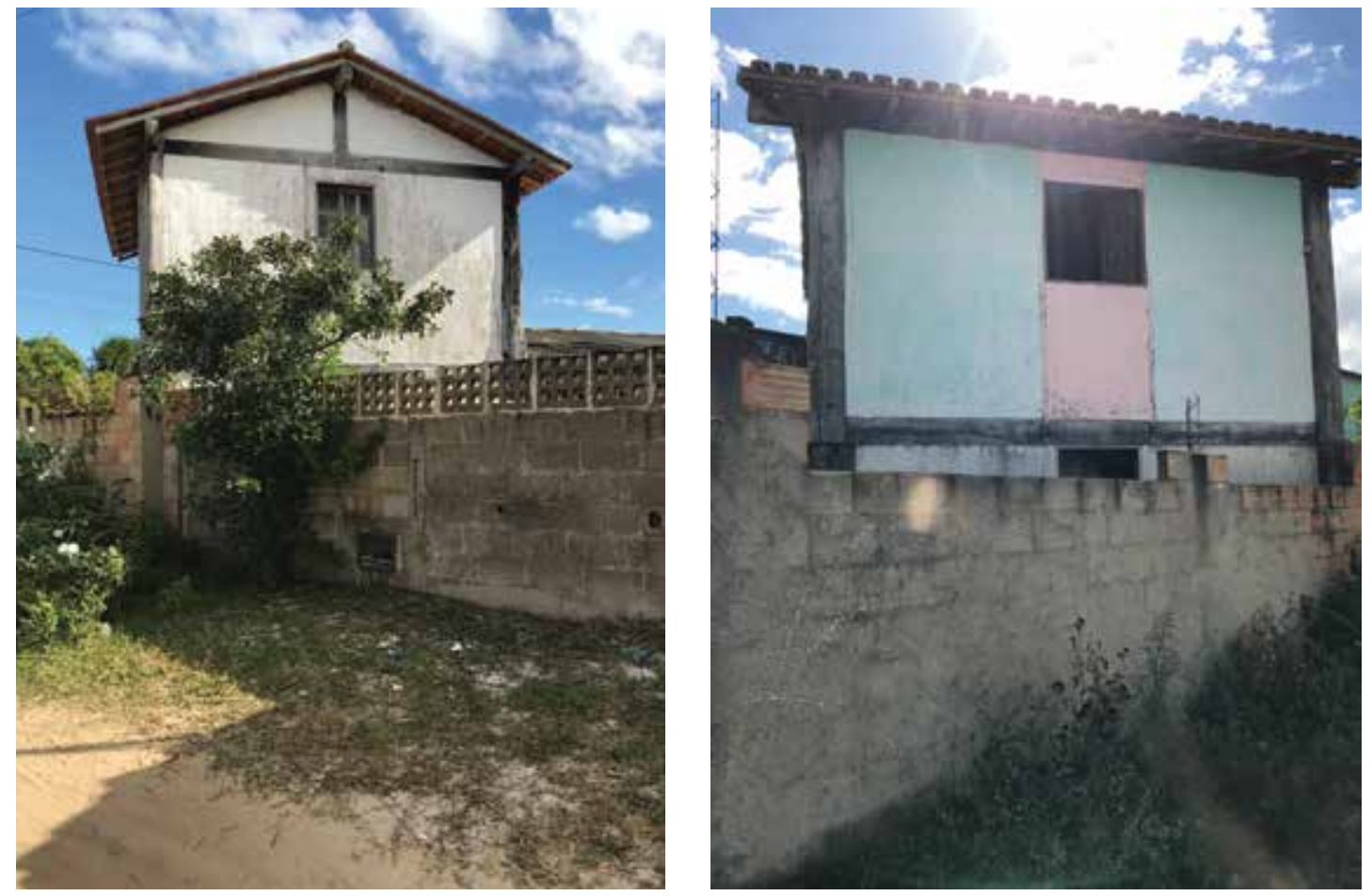

Figuras 60 e 61. Antigo escritório de Zanine, muito modificado. Fonte: Amanda Carvalho. 
assim como os móveis. Na juventude, Seu Tancredo fez canoas, aprendeu com seu pai. Depois trabalhou na Elecunha e, assim que Zanine começou a fazer móveis no galpão cedido pela madeireira, foi com ele para lá. Atualmente seu Tancredo está aposentado.

Benedito trabalhava com os móveis. Foi chamado para ajudar na limpeza do terreno onde Zanine instalaria o Galpão e, após esse trabalho, recebeu a proposta para trabalhar com Zanine na confecção dos móveis. Seu Benedito, que não saiba usar o enxó, uma das principais ferramentas na execução dos móveis, aprendeu tudo com Zanine e atualmente tem a sua própria marcenaria, onde continua executando móveis.

O Peu trabalhava na execução das estruturas das casas. Ele era sobrinho de carpinteiro e, na infância, fez canoas com seu tio. Por já saber trabalhar com madeira, foi chamado pelo seu tio, que trabalhava com Zanine, para trabalhar com eles. Peu até hoje trabalha com madeira, na construção de casas.

Reinaldo colhia as frutas do bosque, levava o filho do Zanine, o Zanininho, para a cidade de charrete e numerava todas as peças da estrutura das casas. Atualmente Reinaldo é pescador. 


\section{móvel-denúncia}

Zanine, ao chegar em Nova Viçosa e ver a quantidade de madeiras queimadas, ficou indignado com essa falta de cuidado com a natureza, que poderia levar toda uma floresta à extinção. Decidiu usar essa sobra de madeira e, ao mesmo tempo, denunciar o desfloretamento. Propôs os "móveis-denúncia", que, segundo ele, provariam a existência dessas madeiras que no futuro provavelmente estariam extintas (Santos, 1993).

De acordo com seu Tancredo, quando Zanine mudou para o Galpão novo, ampliou a quantidade de desenhos dos móveis produzidos:

Ele veio, nós comecamos a trabalhar e depois veio o Simão, com as maquetes. Pelas maquetes a gente faria os móveis. Mini-medidas e aí aumentava nos móveis que a gente faria. E tudo dava certo. E ai o Simão foi embora pro Rio e não veio mais. Mas as maquetes ele deixou aqui. E a gente continuamos [SIC] a fazer, eu e meus companheiros, tudo direitinho. (BARROS, depoimento de 19/08/2017)

Ele fazia esses móveis em pequenas séries, a partir das maquetes. Segundo depoimento dos carpinteiros, Zanine escolhia as madeiras que deviam ser utilizadas para confecção de cada móvel, e, com auxílio das maquetes, faziam os móveis.

A namoradeira, por exemplo, pode ser vista em diversas residências. Percebemse diferenças no desenho das primeiras e últimas namoradeiras: são o resultado de um desenvolvimento construtivo adquirido com a experiência. As primeiras eram feitas inteiras em um único tronco de madeira. Depois disso, mudaram a sua forma de produção, fazendo os braços separados do corpo do móvel, acrescentando-os no final, deixando a construção do móvel mais simples e rápida.

Outra busca constante de Zanine era o conforto:

O que ele sempre falava pra fazer era sentar para sentir o conforto, porque muitas vezes a pessoa tem aquela curiosidade de fazer, mas não sabe o conforto que a pessoa senta. Vocêpode sentar, mas tem que ficar à vontade, num sofá nesse de madeira, ele tem que ter o apoio certinho nas costas. (BENEDITO, 12/09/2017) 


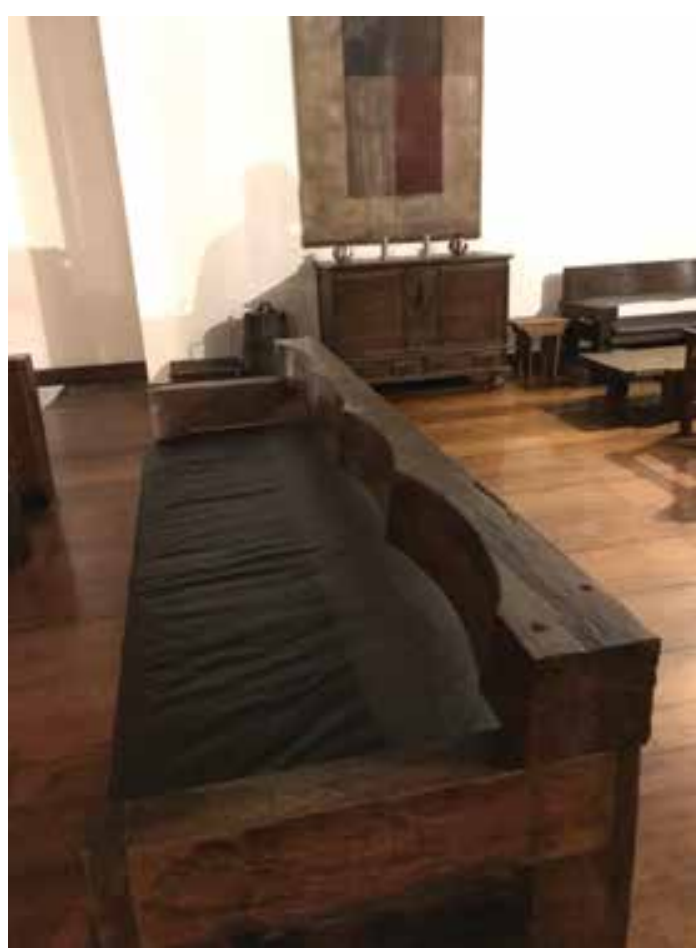

Figura 62. Sofá da primeira casa de Zanine na Joatinga. Segundo Redurino, Zanine sentava no móvel e pedia ajustes na busca de um melhor conforto.

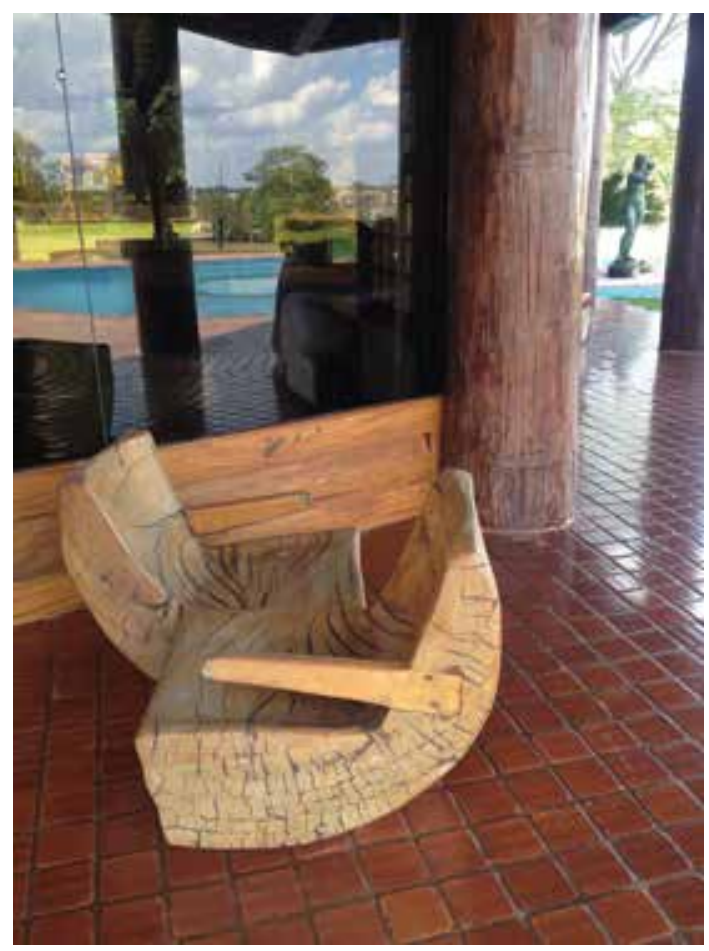

Figura 63. Namoradeira de Betty Bettiol. Fonte: Acervo pessoal da pesquisadora.

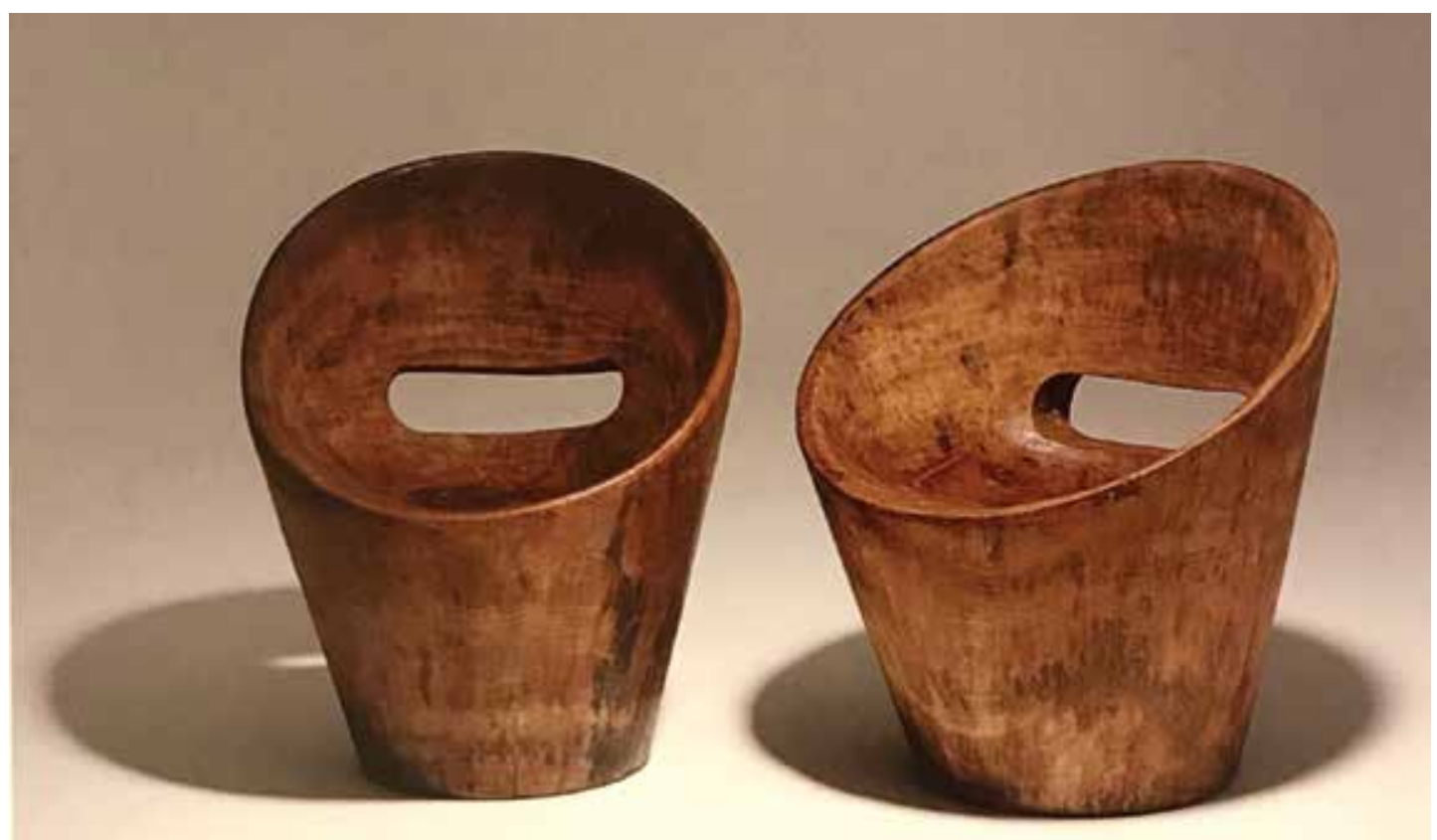

Figura 64. Cadeira tulipa, década de 1970.Fonte: Santos; Sakurai, p.156 
O conforto sempre foi de fundamental importância em todos os móveis desenvolvidos por Zanine. Reduzino nos contou que, durante a construção dos sofás das casas da Joatinga (f.62), Zanine se sentava nos mesmos para saber se estavam confortáveis e para pedir aos carpinteiros modificações que tornassem o sentar mais agradável.

Sobre o formato escultórico dos móveis desenvolvidos em Nova Viçosa, podemos notar as formas arredondadas que são vistas nas canoas, resultado do uso do enxó. Em muitos casos, Zanine tirou proveito dessas formas em seus móveis, permitindo certo balanço, como é o caso da famosa Namoradeira.

Partindo-se do princípio de que o "fazer com", diferentemente do "fazer para", pressupõe estar aberto ao diálogo (Freire, 20014), esses móveis tinham formas belas, proporcionais e curvas como as canoas, resultado do encontro de dois saberes que se complementavam: as proporções tão estudadas por Zanine, enquanto trabalhou com os arquitetos modernos, e o manuseio do enxó, ferramenta que, pelo movimento circular que o carpinteiro faz com o braço ao usa-la, criou móveis únicos.

Assim, ele partia das técnicas já utilizadas pelos canoeiros, que antes as usavam para fazer canoas, e chegava a novas formas e usos, como podemos ver nas diversas poltronas e sofás desenvolvidos pelo Zanine nessa época. Desta forma, ele também preservava técnicas que provavelmente seriam esquecidas se o seu uso não encontrasse novas necessidades.

A madeira era utilizada na sua forma natural, como podemos ver em muitas de suas mesas, em que usava um tronco de ponta cabeça com suas raízes voltadas para o céu suportando um tampo de vidro. Segundo Santos:

Ele soube tirar partido de todas as características físicas e morfológicas dessas madeiras: dos troncos tortuosos com grandes diâmetros, dos vazados naturais, dos miolos ocos resultantes da ação dos cupins, formados naturalmente no interior das árvores, teve até mesmo a intuição genial de seccionar o veio da madeira, de interromper suas tensões internas, de tal forma que ela pudesse continuar mantendo seus processos de contração e expansão nas grandes peças por ele criadas. Em última instância, com a produção de Nova Viçosa Zanine desafiou e pôs em questão as potencialidades do trabalho com a madeira e acabou fazendo-a trabalhar a sen favor. (SANTOS, 1993, p. 172)

Todo o período em que Zanine esteve em Nova Viçosa foi marcado por idas e vindas ao Rio de Janeiro, cidade onde mantinha um escritório de arquitetura e de onde surgiam as encomendas de novos projetos que seriam executados em Nova Viçosa. Ele ficava entre 15 e 20 dias no Rio de Janeiro, depois retornava para Nova Viçosa. Por isso, precisava trabalhar a distância com os carpinteiros, sabendo que os mesmos fariam os móveis conforme seu projeto, era um trabalho baseado na confiança e no reconhecimento da habilidade dos carpinteiros. Benedito comenta (17/08/2017): "Eu trabalhava nas casas, quando não tinha (móveis), mas mais nos móveis. E aí ele acreditou, como eu podia trabalhar, ele deixava eu 
trabalhando e deixava eu 15 dias pro Rio, e voltava, marcava as peças que eu podia fazer".

Como utilizavam os restos do desmatamento da floresta, não trabalhavam com madeiras específicas, mas sim com todas que fossem encontradas. Sendo assim, Zanine escolhia e separava a madeira que seria usada para cada móvel, conversava com os carpinteiros, dizendo com qual deveriam fazer determinado móvel, fazia as marcações necessárias e, a partir das maquetes e das marcações, os carpinteiros executavam o móvel na escala 1:1.

As ferramentas usadas eram principalmente a motoserra, para cortar o tronco da árvore no tamanho do móvel e para tirar a casca. Depois disso usavam a enxó, para fazer o formato curvo, além do machado, para pequenos detalhes, e a plaina, quando a superfície fosse lisa.

A madeira já trazia bruta e serrava para fazer banco, para fazer mesa. A madeira chegava. Às vezes com a casca. Uma rodela de madeira, como essa daí. Isso daí, ó, é madeira de lá ainda. Pra você ver. São madeiras que ele trazia. Furada, velha. Enxó, machado, motosserra. São as ferramentas que mais utilizavam. Às vezes era uma peça grande, grossa e a gente cortava com a motoserra, para diminuir mais o trabalho da enxó. Era assim que era. A plaina curvada era para a gamela, quando tinha a gamela grande. Aquele formato dela bojuda, era para aplanar por dentro. O enchó era para tirar a madeira, fazer um entalho. Porque às vezes tinha uma madeira que era muito lisa, ai então o enchó era o detalhe, para ficar aquele racho de enchó. (BENEDITO, depoimento de 17/08/2017)

Quando questionado sobre o acabamento usado nos móveis, Benedito nos disse que Zanine "usava muito cera pro brilho. E penetrol, essas coisas, um bocado de tipo de veneno que a gente aplicava na madeira". Desta forma podemos ver que Zanine protegia a madeira contra xilófagos e também pensava no acabamento com cera.

Como havia muitas canoas que não eram mais usadas na região, Zanine fez muito móvel a partir delas:

Ele trazia canoa velha para cortar, para móveis. Eu mesmo andei faz̧endo umas canos quando era mais novo. Mas [nessa época] a gente cortava mais canoas velhas, de oiticica, de verana e fazia móveis. Ele comprava, fazia a proa com a popa, emendava direitinho e ficava bonitão. Ele fazia móveis. (BARROS, depoimento de 19/08/2017)

Nesse período de experimentação, Zanine construiu casas geométricas, a triangular e a piramidal, assim como racionalizou a produção de estruturas de madeira para residências. Ao mesmo tempo, fez móveis escultóricos, união clara com a técnica utilizada pelos moradores, mas agora com uma nova intenção, resultando em novas formas.

O que aparece como uma contradição — pensar em formas geométricas e em racionalizar a construção de casas, por um lado, e fazer móveis pesados, com uso de 
madeira abundante, por outro - pode ser entendido a partir do percurso da vida de Zanine.

Inicialmente, como ele mesmo diz, acreditou que a indústria poderia melhorar a vida das pessoas - foi quando abriu a fábrica de móveis $Z$, racionalizou a produção de móveis e usou painéis finos e leves de contraplacados, mas logo percebeu que os interesses dos donos de fábricas eram muito diferentes dos seus. Enquanto os primeiros queriam aumentar a produtividade e o lucro, Zanine queria experimentar novas soluções e baratear o custo dos móveis para que os mesmos estivessem no maior número de casas possível, melhorando a vida dos seus habitantes.

O pensamento do desmontável continuou na obra do arquiteto nas casas pré-elaboradas, feitas em Nova Viçosa e enviadas desmontadas para todo o Brasil, onde seriam remontadas no terreno definitivo. Já não existia a ideia da industrialização, mas sim de um pensamento construtivo adaptado às técnicas artesanais para facilitar a execução dessas casas. A sua aparência bruta é o resultado da sua forma de produção, podendo-se ver as marcas do enxó nas vigas e pilares de madeira.

Sendo assim, apesar do racionalismo na proposta das estruturas pré-elaboradas, elas ainda eram construídas de forma muito artesanal — não eram industrializadas. Não era a intenção de Zanine criar uma indústria: ele buscava o diálogo com o natural como estilo e com as técnicas tradicionais de construção.

Esse diálogo, em vez de destruir as possibilidades de desenvolvimento da técnica utilizada pelos canoeiros, mantendo o seu uso apenas para a proposta inicial (esculpir canoas dentro de um só tronco) permitiu um desenvolvimento da técnica e aplicação da mesma para outros usos, reestabelecendo a sua importância na atualidade e servindo de meio para construção de objetos úteis para o dia a dia. Dessa forma, Zanine valorizou o saber-fazer do artesão, a natureza do Brasil, além de preservar uma técnica construtiva autóctone.

Além disso, ele viu nas culturas autóctones o quanto estas aproveitavam a natureza como matéria-prima, porém com a sabedoria de nunca acabar com essas espécies, pois sabiam a importância das mesmas para a sua sobrevivência.

Os móveis, objetos e esculturas feitos por ele nessa época evidenciam esse pensamento sobre a preservação da natureza, assim como recuperam o conhecimento do saber-fazer dos moradores do local.

Mas não se pode ignorar o fato de que esses móveis encantaram a burguesia do Rio de Janeiro, que os comprava apesar do seu alto valor de mercado, permitindo que Zanine continuasse a produzí-los. E aí temos uma contradição, pois esses móveis nunca poderiam ser comprados por pessoas simples; ficavam muito caros pela quantidade de madeira em uma única peça, pelo tempo necessário na confecção das mesmas porque não eram feitos em larga escala (quando possível eram feitos em pequenas séries, mas muitos eram únicos, pois possuíam a forma da raiz ou do tronco da árvore).

Os móveis-denúncia chocam por deixar à mostra várias contradições da nossa sociedade: desmatamento das florestas, a qualidade da madeira que seria descartada, as diferenças sociais e econômicas do Brasil. 


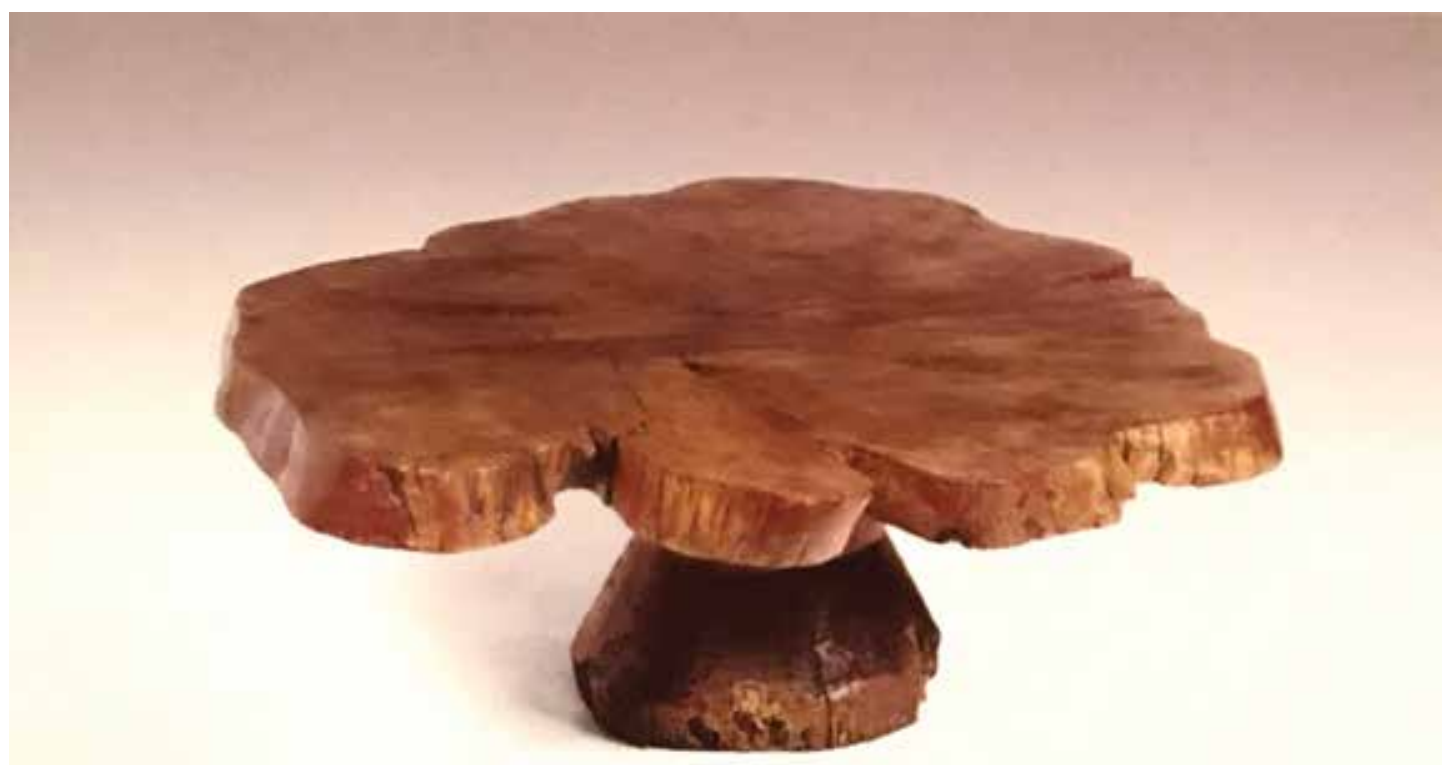

Figura 65. Mesa de centro, década de 1970, pequi de resíduo florestal. Fonte: Santos; Sakurai, p.171

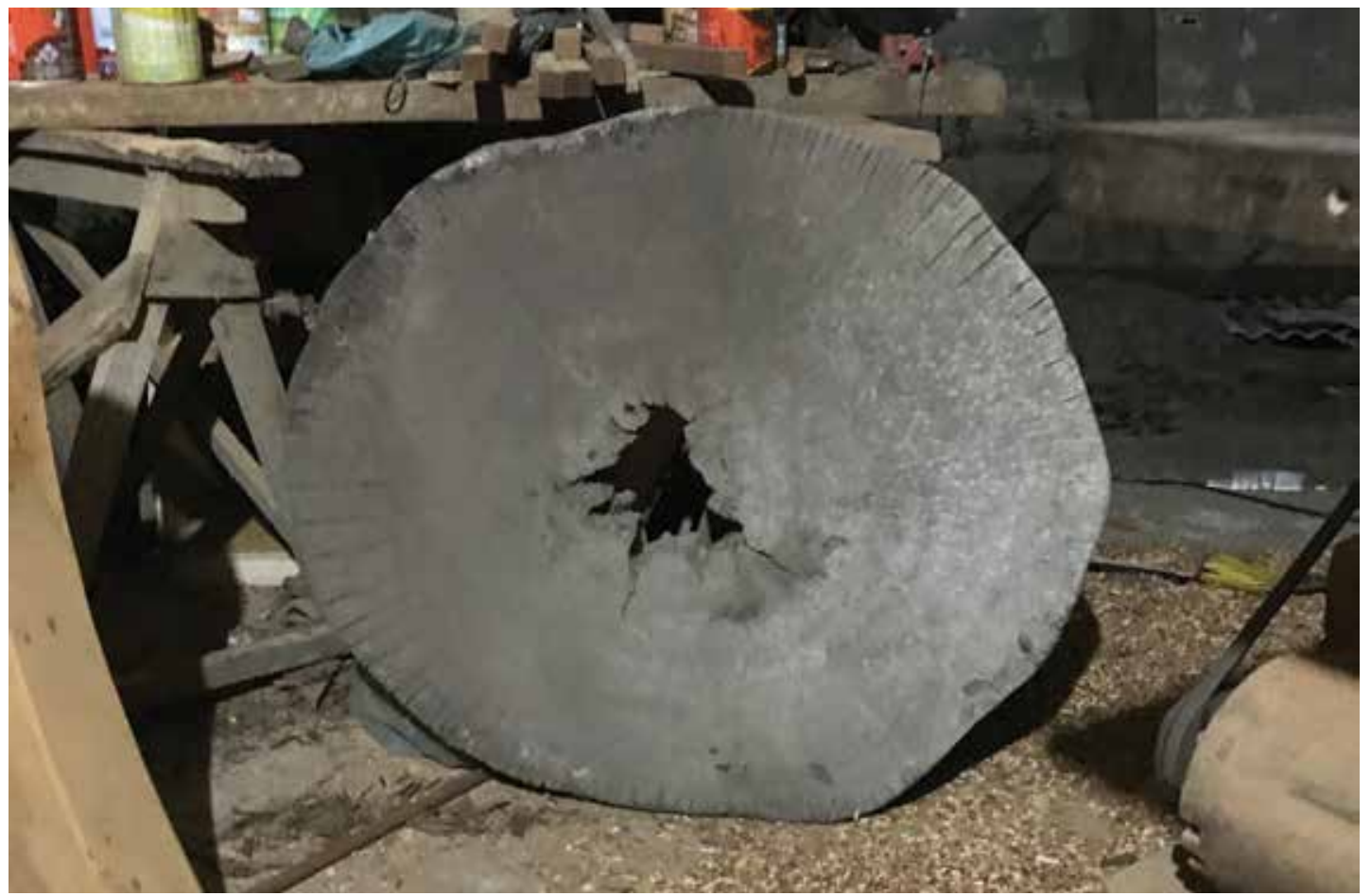

Figura 66. Tronco da época da oficina de Zanine, guardado pelo Benedito. Fonte: Amanda Carvalho. 
Percebe-se que a fase de Nova Viçosa foi um desenvolvimento da obra de Zanine, na qual preservou formas de fazer experimentadas por ele e que considerou boas, negando as que não tiverem o resultado esperado. O seu retorno ao lar, ao sul da Bahia, foi uma escolha feita durante a sua maturidade, assim como a opção por voltar a usar as técnicas tradicionais mesmo depois de ter montado a fábrica de móveis $Z$, na qual produziu móveis a partir de maquinário simples. 


\section{casas}

\section{pré-elaboradas}

Após o primeiro momento de experimentação, no galpão da Elecunha, onde desenvolveu móveis, Zanine construiu seu próprio galpão e, ampliando sua produção, começou a fazer casas:

Ai depois dos móveis ele começon a fazer, ainda estava faz̧endo os móveis, mas ele começon a faz̧er casas pré-fabricadas. Ele faria casas, só encaibrava, não ripava. E depois tinha o manual. A gente pegava o manual e quem saía para montar elas fora ai levava o manual para montar. Ele achou que a gente não tinha dificuldades pra trabalhar. (BARROS, depoimento de 19/08/2017)

As residências eram projetadas no Rio de Janeiro e suas estruturas fabricadas na Bahia, em Nova Viçosa. Zanine as nomeou "pré-elaboradas"’ pois eram projetadas a partir de módulos estruturais desmontáveis.

Explicando como as casas dessa época eram feitas, Ricardo Caruana ${ }^{8}$ nos diz que, na maioria dos casos, quando um novo projeto de arquitetura era encomendado, eles visitavam o terreno do projeto e, depois, iam para o Rio de Janeiro, onde desenvolviam-no. Zanine usava papel milimetrado para desenhar, começava pela planta e logo passava para fachada. O engenheiro Hélio Olga ${ }^{9}$

7 Parte deste capitulo foi apresentada no congresso Design e Materiais 2017, na Universidade Univille, em Joinville. Pode ser vista na integra no link, visualizado no dia 08 de janeiro de 2018: < bttps:/ /

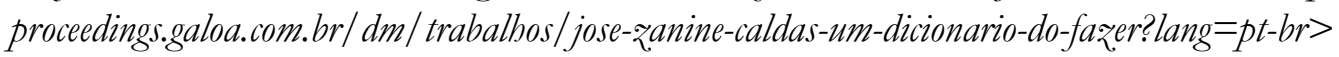
8 Arquiteto que trabalhou com Zanine neste periodo, tanto no desenvolvimento de projetos, quanto na construção das casas em Nova Viçosa. Entrevista realizada em 25/11/2016.

9 A relação do então recém formado engenheiro Hélio Olga com Zanine se deu entre o final de 1978 e o início de 1979, quando foi convidado pelo tio para montar algumas casas pré-elaboradas (forma como Zanine nomeou o seu método de produção em Nova Viçosa) de Zanine. O tio de Hélio tinha alguns terrenos na Granja Viana, local que não era valorizado, e queria construir nos terrenos para depois vendê-los. Construíram 2 casas no local e, depois, Hélio encomendou a sua própria casa para Zanine. 
comenta a ligação do desenho feito por Zanine com a forma de produção em Nova Viçosa:

Enfim, o Zanine é um cara que tinha essa coisa do desenho no milimetrado e isso tinha uma série de razõos. Então ele sempre tinha a modulação, era o quadradinho, $1 \mathrm{~m}$, e isso acaba refletindo, desde a saida, até o final. Quando o desenho está ligado à producão, ele acaba sendo o reflexo, uma coisa da outra. (OLGA, depoimento de 02.02.2017)

O engenheiro se refere a alguns métodos desenvolvidos por Zanine para facilitar a produção das casas. Um deles era modular a casa, método que veremos adiante. Outro era trabalhar com uma retícula no piso (f.67), no local da produção dessas casas, em Nova Viçosa. Essas formas de fazer foram confirmadas pelo arquiteto Ricardo Caruana e pelos carpinteiros de Nova Viçosa. Hélio Olga descreve como era essa retícula:

Como ele trabalhava com mão de obra do pessoal que fazia barco, o pessoal era analfabeto. Ele fez. um negócio e isso aqui era múltiplo de metro inteiro. Porque o cara não sabe medir, mas sabe contar. Ele fez uma retícula de metro em metro, os pilaretes. Ele chegava lá para o cara e falava: Eu quero uma casa 3x3. O que o cara fazia? Pegava uma viga e colocava aqui em cima. Cortavam. Ai ele botava outra aqui, do lado de fora. Cortava. Ai ele botava uma viga aqui, cortava. Ele fazia divisão, fazia tudo o que podia aqui. Fazia o barroteamento de piso. Isso era, o piso do térreo, o piso superior e o telhado. E ai o que ele fazia? Montava o térreo. E aí, em cima disso, sem o pilar, ele montava isso aqui [desenhou o anel de vigas do segundo andar e do telhado]. Porque como ele trabalhava com a madeira só serrada, a madeira tinha mais ou menos $10 \mathrm{~cm}$ de largura, por mais ou menos $30 \mathrm{~cm}$ de altura e era mais ou menos reta. Então o cara tinha que por a madeira no lugar para cortar. Porque não adianta medir, aqui tem 10, porque aqui tinha 9,5. E era torto também. Então ele punha fisicamente. Ai, em cima disso ele punha o segundo andar. Então se essa peça estava torta, ele colocava o segundo andar em cima disso, sem os pilares. Ai ele montava o anel do telhado. E depois punha o telhado. (OLGA, depoimento de 02.02.2017)

A malha era permanente e, segundo Caruana, feita da seguinte forma: inicialmente cavavam buracos no chão, espaçados em $1 \mathrm{~m}^{2}$ até encontrarem a terra dura. Não faziam sondagem, pois não tinham o maquinário para isso, então, para saberem se chegaram na terra dura faziam o "teste do calcanhar", que foi descrito da seguinte forma pelo arquiteto Caruana:

Precisávamos chegar na terra dura. Tínhamos que tirar toda a terra vegetal para chegarmos na terra mineral, sem matéria orgânica. Não podíamos ter deformações, então, após encontrada a terra mineral, precisávamos nos certificar de que ela estava suficientemente dura para colocarmos a casa em cima. Então dávamos uma apertada com calcanbar, usando o salto do sapato e víamos o quanto o salto entrou na terra. Era uma maneira empirica, mas que, com um pouco de prática, sabiamos, pela marca do salto, se a dureza era suficiente. Caso encontrássemos pedras 


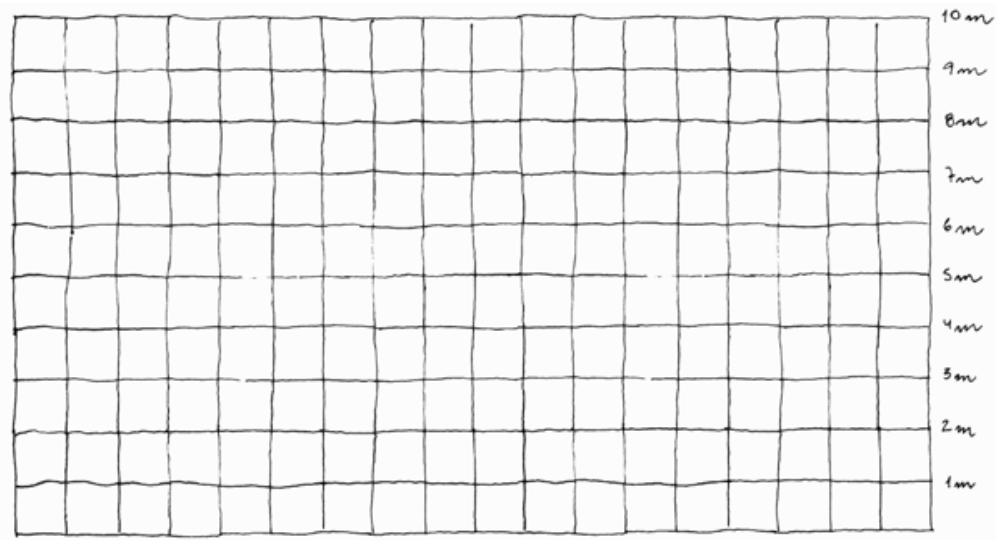

Figura 67. Vista superior mostrando modulação do piso. A cada encontro de linhas havia uma base. Desenho: Amanda Carvalho.

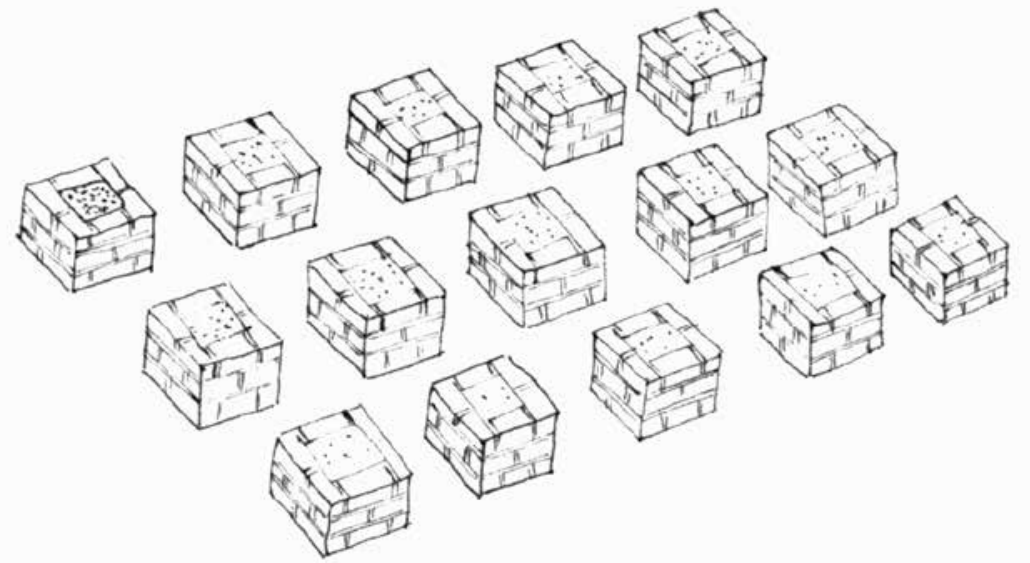

Figura 68. Ampliação da base modulada a cada $1 \mathrm{~m}$. Desenho: Amanda Carvalho.

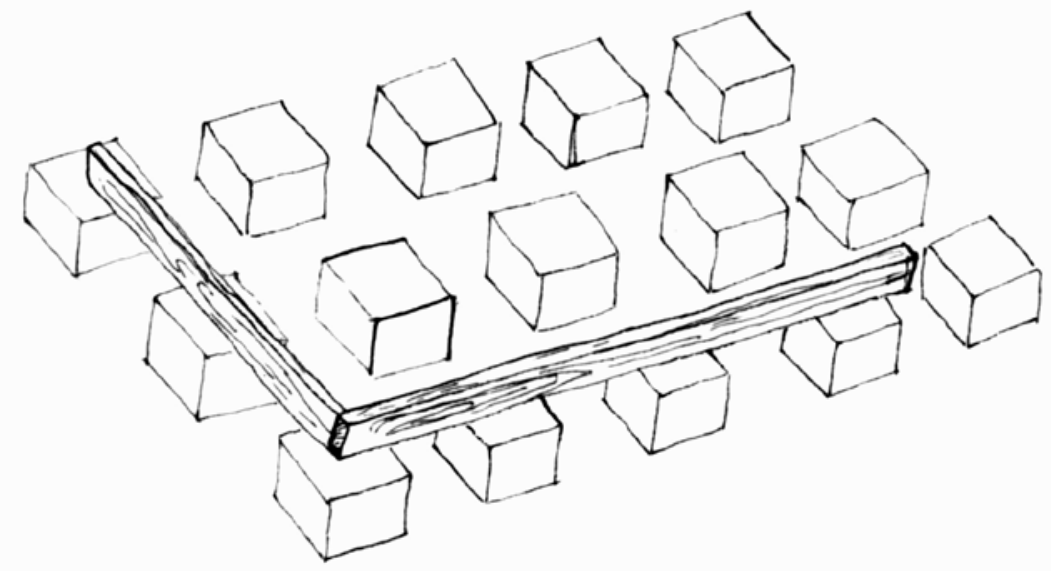

Figura 69. Modulos com vigas inferiores apoiadas. Desenho: Amanda Carvalho. 


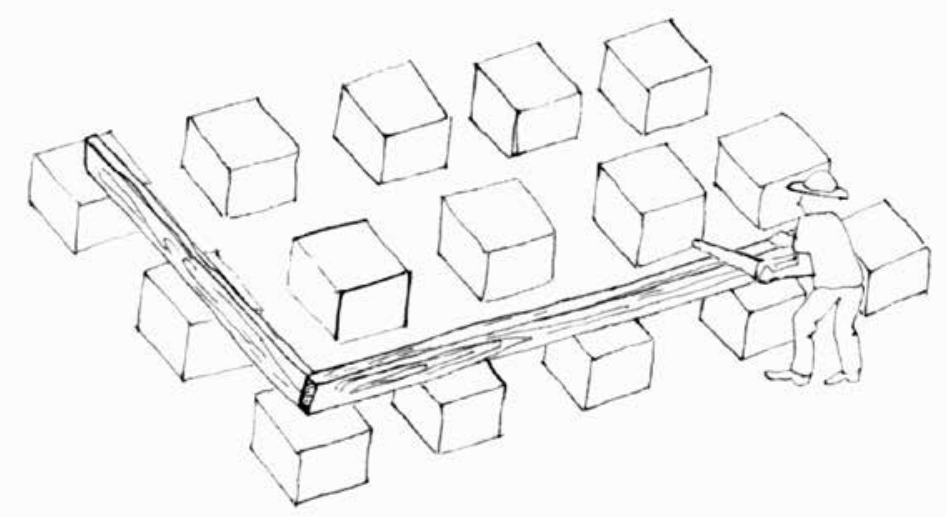

Figura 70. Corte das vifas inferiores. Desenho: Amanda Carvalho.

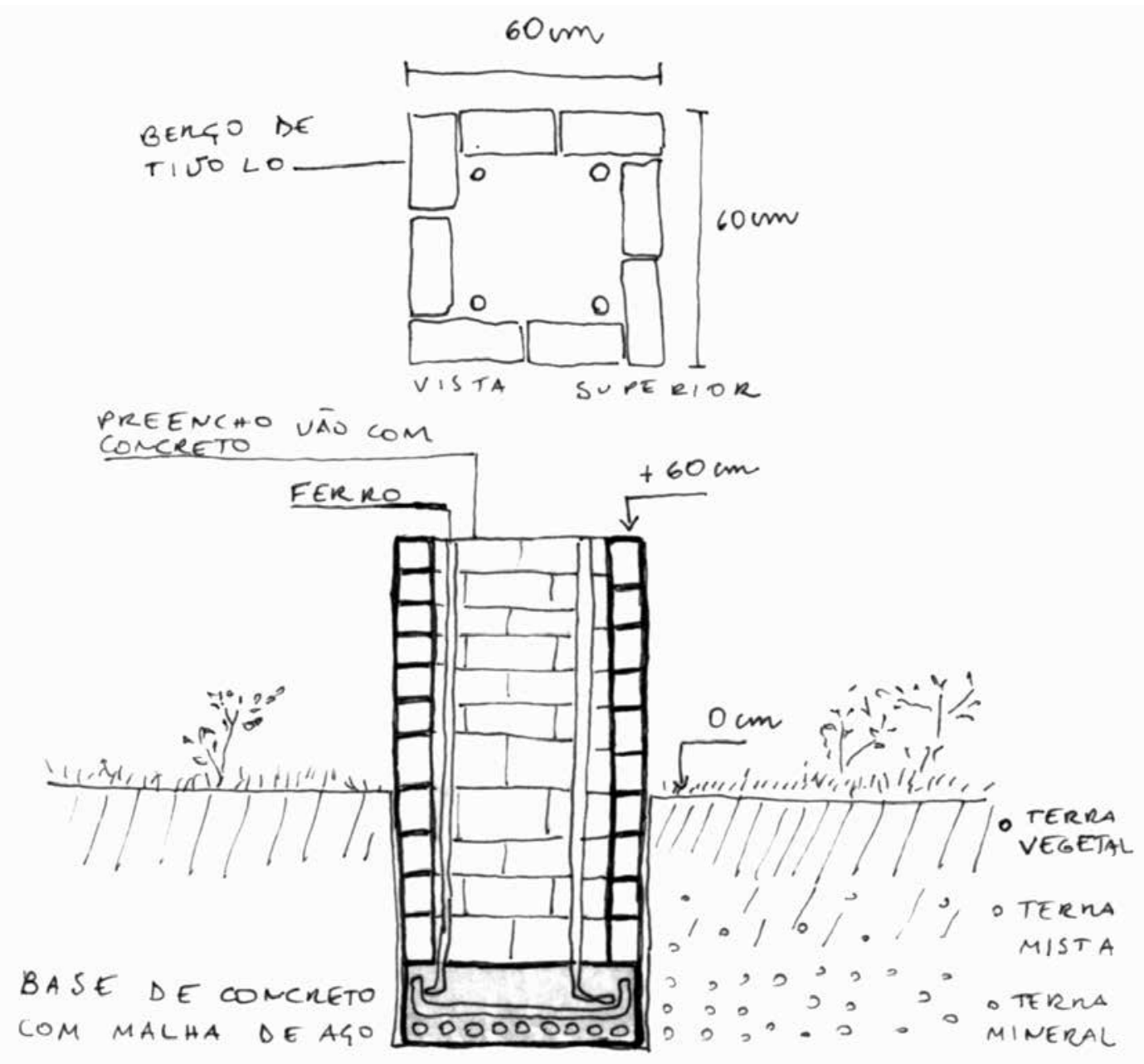

Figura 71. Corte da fundação. Desenho: Amanda Carvalho. 
no caminho, podiamos colocar a fundação em cima, mas precisávamos nos certificar se o tamanho da pedra era suficiente para suportar a casa, então fazíamos buracos no arredor, para precisar o tamanho dela. (CARUANA, depoimento de 25.11.2016)

Após o "teste do calcanhar", eles colocavam 4 vergalhões de aço e preenchiam o fundo com concreto. Depois faziam uma moldura em tijolo, com o centro vazado. Despejavam o restante do concreto nesse miolo. Essa base tinha $60 \times 60 \mathrm{~cm}$ e ficava a $60 \mathrm{~cm}$ do solo (f.71).

Além do piso reticulado(f.68)., para facilitar a produção em Nova Viçosa, eles usavam módulos estruturais. Podemos imaginar esses módulos como quadrados no espaço. Segundo Caruana, os módulos 5x5m e de 7x7m (f.72 e f.73) eram muito usados por Zanine, também nos diz que o projeto dessas casas era feito a partir dos módulos estruturais:

Então você pegava dois módulos de $5 \times 5$ m e deixava um espaço de 10 no meio e você tinha, na verdade, $50 \mathrm{~m}^{2}$ centrais e mais 25 de cada lado. Ou, se fosse inclinada a montanha, você podia botar um módulo 2 pra cima, um módulo 2 para baixo. E tudo era projeto especial. Não tinha projeto pré-fabricado. O que tinha era um sistema estrutural modulado para resolver múltiplos projetos. (CARUANA, depoimento de 25.11.2016)

Ainda segundo Caruana, o módulo de $7 \times 7 \mathrm{~m}$ era muito usado por Zanine, pois permite dois quartos de $3,5 \mathrm{~m}$ e uma sala. E, caso sejam necessários 4 quartos, é só usar dois módulos de $7 \times 7 \mathrm{~m}$, colocar cada um em um canto da estrutura, com uma sala no meio (f.72). Das duas formas, a estrutura estará resolvida e você tem várias possibilidades de layout.

O projeto da casa era pensado a partir desses princípios de produção, a retícula no piso e o módulo estrutural. Em Nova Viçosa, o tronco era recebido redondo, as costaneiras eram retiradas com o uso de um machado (f.74).

Após isso, marcavam as peças, para efetuarem o desdobro, transformarem o tronco em toras. $\mathrm{O}$ desdobro era feito com uma serra manual e eram necessárias duas pessoas para cortar as peças(f.75 e f.76):

Isso épara uma tora. Ai tem que colocar uma linha, ai tem que colocar uma tintażinha, para molhar ela. Para segurar e bater, para poder alinhar, para poder o cortador, o pessoal da serra, ir serrando consoante àquela linha. A serra tem 2,5 m mais ou menos. Essa que vai um em cima e um em baixo. (BARROS, depoimento de 19/08/2017)

Depois Zanine comprou dois engenhos horizontais, máquinas que faziam o desdobro do tronco, o que facilitou a produção das casas.

Hélio Olga, quando questionado sobre qual era a madeira utilizada por Zanine, afirma: "Tudo misturado. Ele nunca escolheu uma madeira. Ele pegava restos". De acordo com Tancredo, explicando sobre como as madeiras chegavam a Nova Viçosa: 

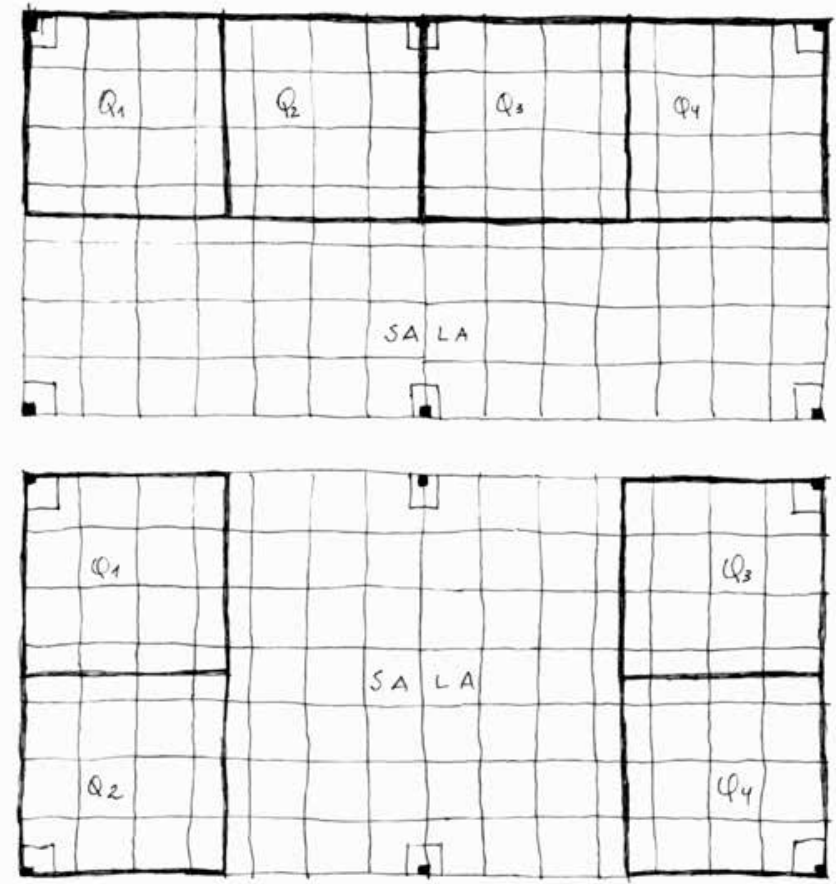

Figura 72. Duas possibilidades de layout a partir do módulo de $7 \mathrm{~m} \times 7 \mathrm{~m}$. Desenho: Amanda Carvalho.
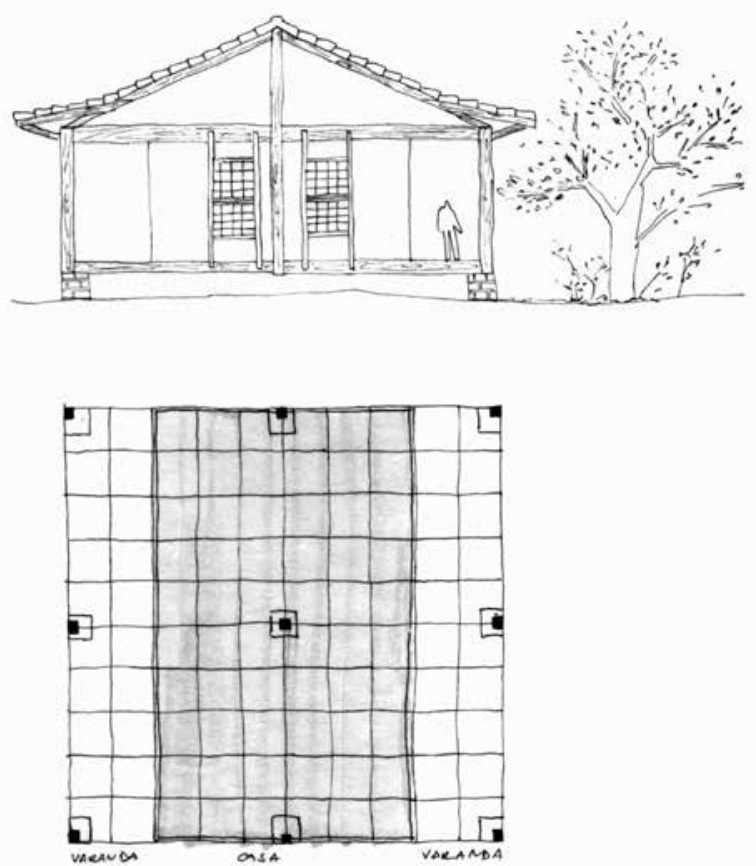

figura 73. Possibilidade de casa feita a partir de módulo de $5 \mathrm{~m} \times 5 \mathrm{~m}$. Desenho: Amanda Carvalho. 


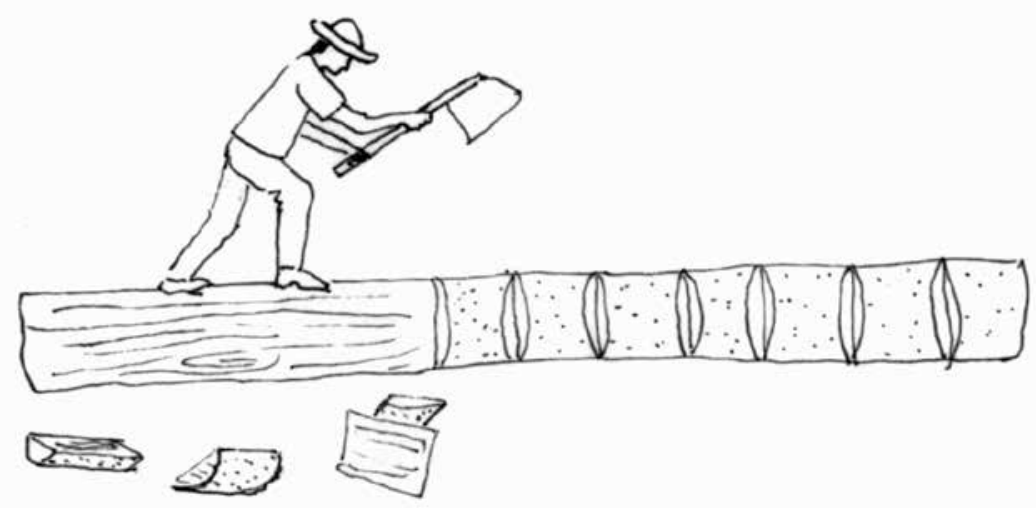

Figura 74. Tirar a costaneira. Processo era feito assim ou com o uso de serra elétrica. Desenho: Amanda Carvalho

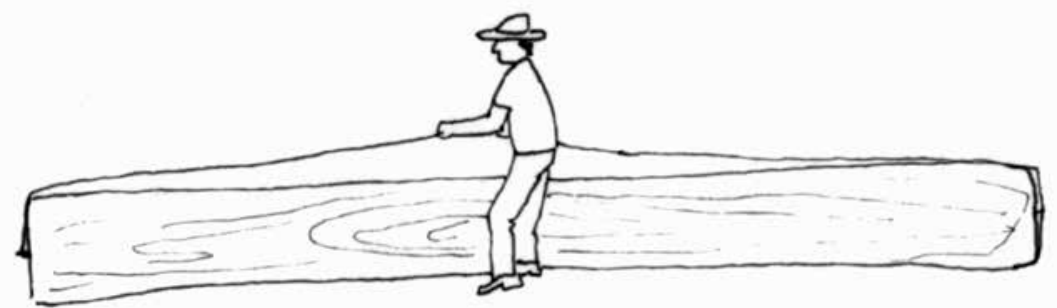

Figura 75. Marcação das toras com fio e tinta. Desenbo: Amanda Carvalho.

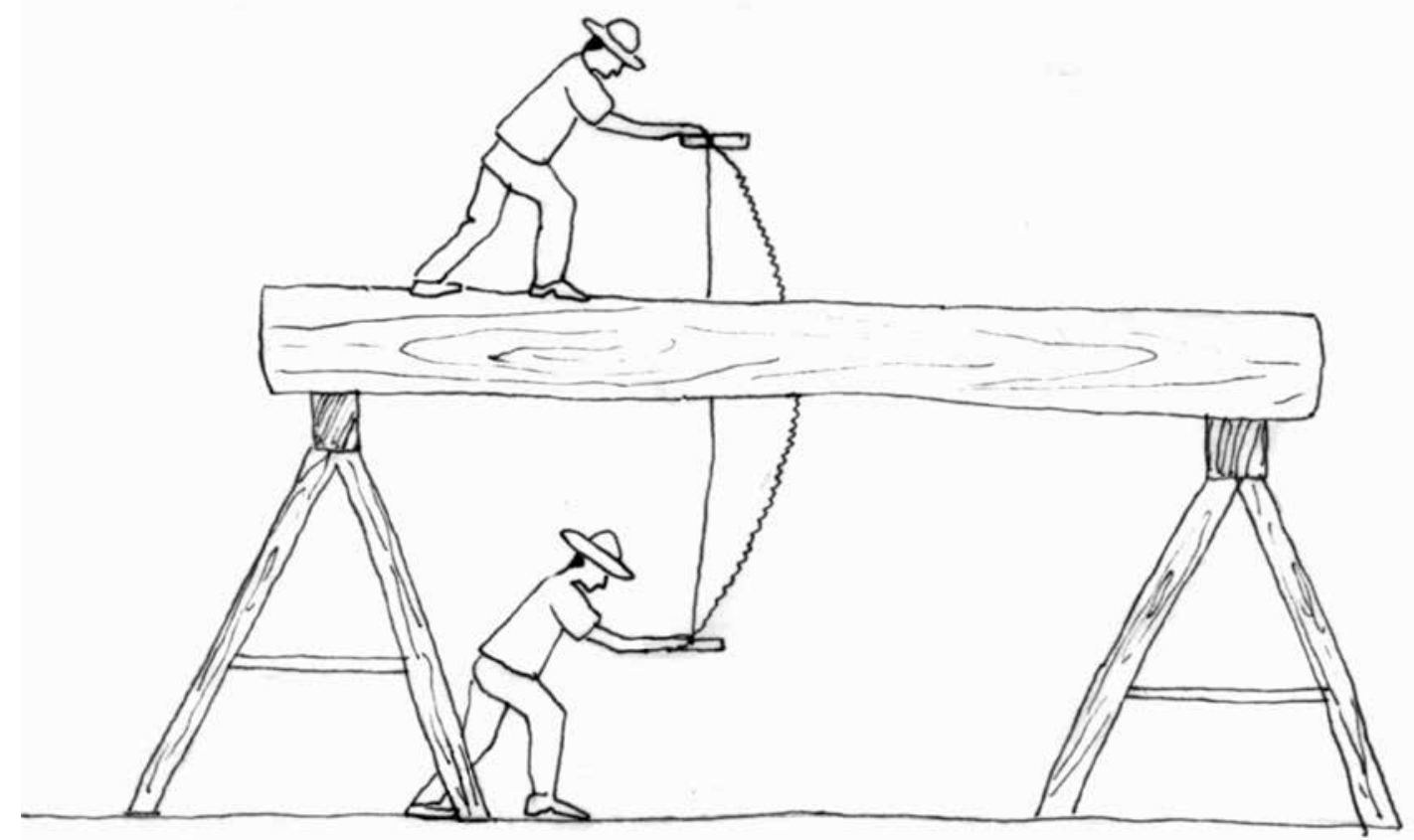

Figura 76. Desdobro com serrote de $2 m$ ou engenho horizontal (comprado posteriormente). O desdobro era mais usado na produção das casas do que dos móveis. Desenho: Amanda Carvalho. 
Elas vinham lá da mata de Porto Seguro, por aí. Madeira mais antiga, madeira queimada. Pequi, Juerana, Oiticica, Jaqueira queimada, aproveitava muito. Folheiro, várias madeiras. Ele trazia. Tinha um caminhão, trazia direto. (BARROS, depoimento de 19/08/2017)

Para o corte do tronco, eles partiam do tamanho dos módulos estruturais e, também, dos padrões de bitolas mais usadas:

Você tinha vigas inferiores, em geral começou em $20 \times 20 \mathrm{~cm}$ porque a gente fazia do tronco redondo, mas quando a gente comecou a trabalhar com madeira serrada era muito $15 \times 30 \mathrm{~cm}$ para vigas inferiores e superiores. E tinham muitas colunas de 20x20. Começou com 30×30, diminuiu pra 20x25 e chegamos a fazer muita coisa de 15 também. Depois tinham as espigas do telhado, que a gente usava na diagonal, peças de 20x20. Ai tinham os barrotes, que em geral eram de $5 \times 20$, e de $5 \times 15$. Tinham caibros $5 \times 20$ ou 5×15, dependia do vão. Mas tinha, sim, uma padronização. (CARUANA, depoimento de 25/11/2016)

Os padrões das bitolas permitiram que Zanine tivesse uma lista (f.77) com a quantidade de peças de cada tamanho que seriam usadas em cada residência, facilitando o corte das peças, o trabalho do pessoal do almoxarifado, que fazia o manual de montagem das casas, e também o carregamento das peças no caminhão.

Segundo Caruana, após os troncos cortados nas seções necessárias era feita a montagem da estrutura no piso reticulado. Primeiro cortavam as vigas inferiores (f.69 e f.70) e superiores, tiravam as superiores de cima da estrutura, deixando apenas as vigas inferiores, a partir das quais colocavam os pilares. Prendiam com as cantoneiras. Isso tudo era contraventado provisoriamente com um bastidor. Colocavam as quatro vigas de cima e surgia um cubo (f.78). Colocava-se a estrutura do telhado até os caibros, não ripavam, isso só era feito na montagem da casa no terreno final. Essas peças eram parafusadas com cantoneiras metálicas e eram numeradas (f.80).

As cantoneiras eram chapas cortadas, um perfil L (f.79), cortado a cada $15 \mathrm{~cm}$. Esse L era o berço da viga. O L tinha 2 furos em cada face, para fixação na viga.

Após a estrutura pronta, numeravam todas as peças. Esse passo era de fundamental importância para que a estrutura, inicialmente montada em Nova Viçosa, correspondesse à estrutura no terreno final. Para conseguirem montar da mesma maneira, havia um desenho executivo de montagem das casas e uma marcação nas peças de madeira. Reinaldo, responsável por numerar as peças, explica como era a ferramenta usada para numerar as peças:

Era um pedaço de ferro e na ponta do ferro tinha um número. Era 01, 02. Era C1, C2, A1, A2, B. Tudo assim. Vamos supor, se fossem os caibros, Ai colocava C1, C2, C3, dependendo da quantidade de caibro. Viga ai botava, vamos supor, se foi $C$, ai botava $B$. E ai as colunas a mesma coisa também. E aí, pela numeração, já ia tudo anotado. Dava para ele (o rapaz do almoxarifado) e dizia: coluna foi tanto, caibro foi tanto, e ai, tudo para ele. As vigas foi tanto. 


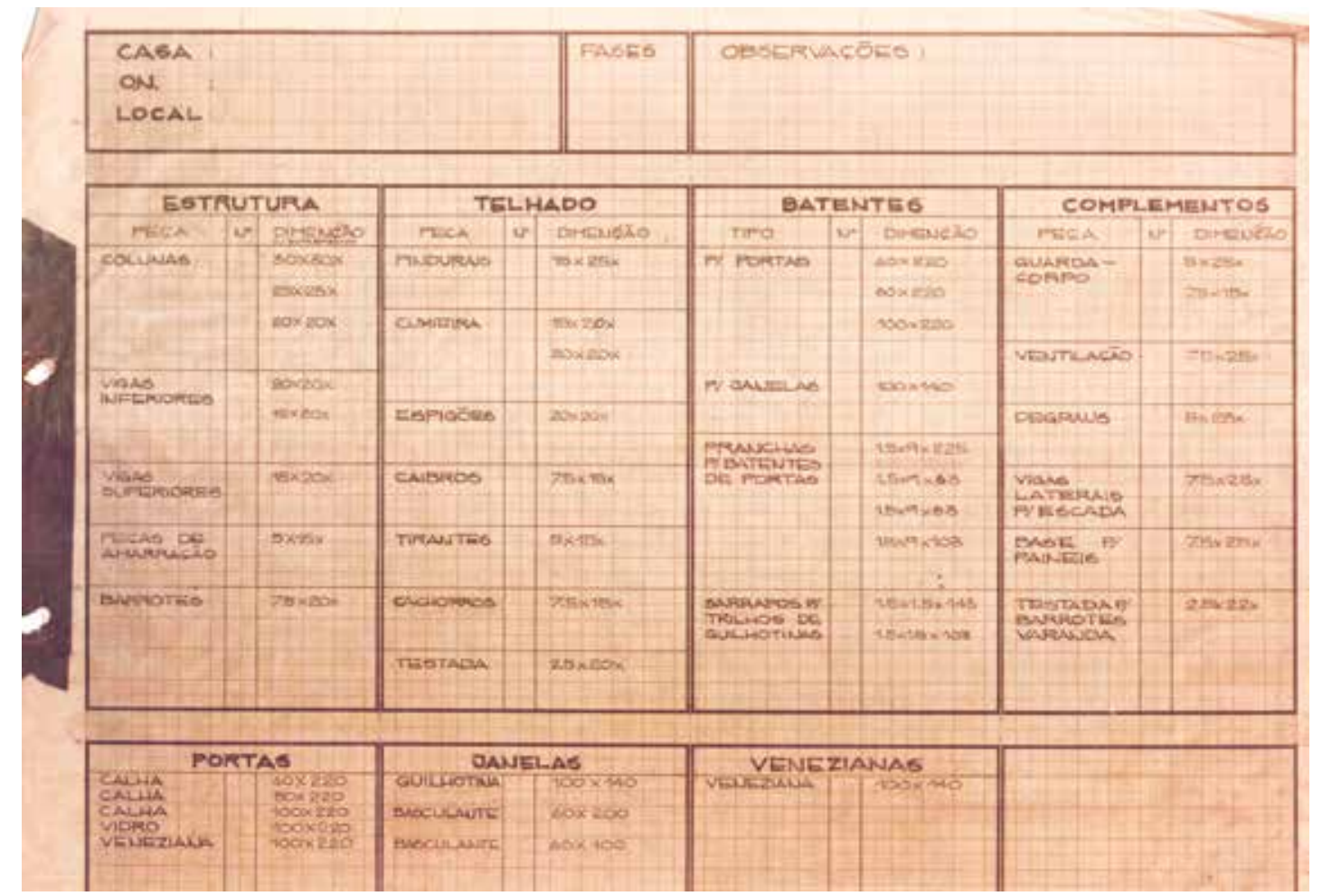

Figura 77. Lista de quantidades de peças por residência. Fonte: Ivan do Valle.

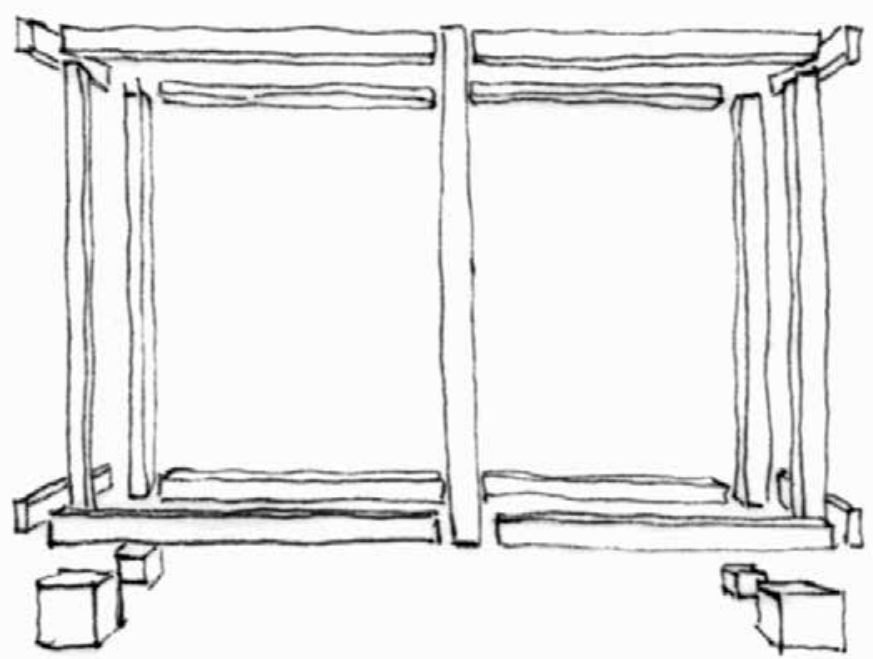

Figura 78. Cubo no espaço. Desenho: Amanda Carvalho. 


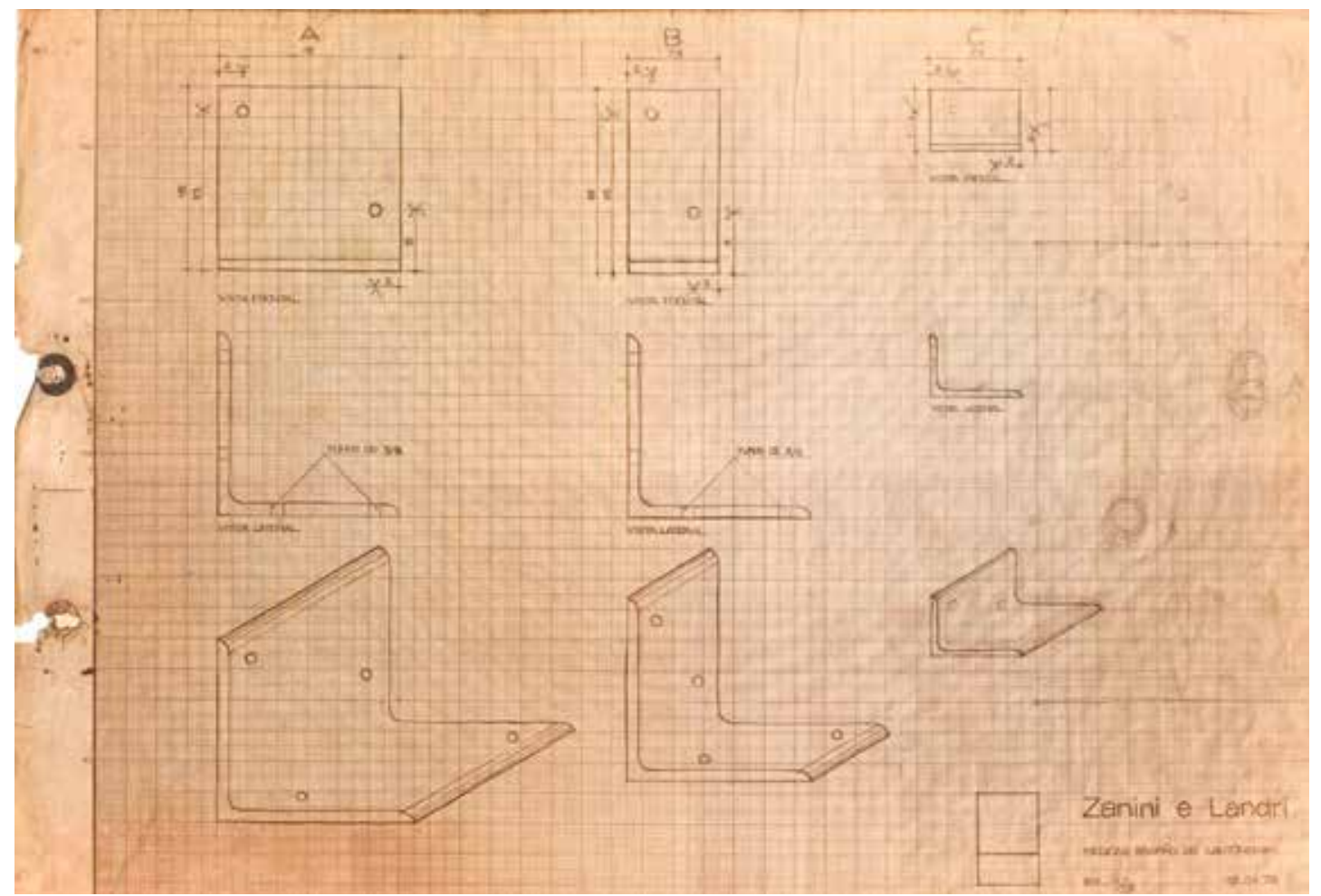

Figura 79. Cantoneiras. Desenho de 1978. Fonte: Ivan do Valle.

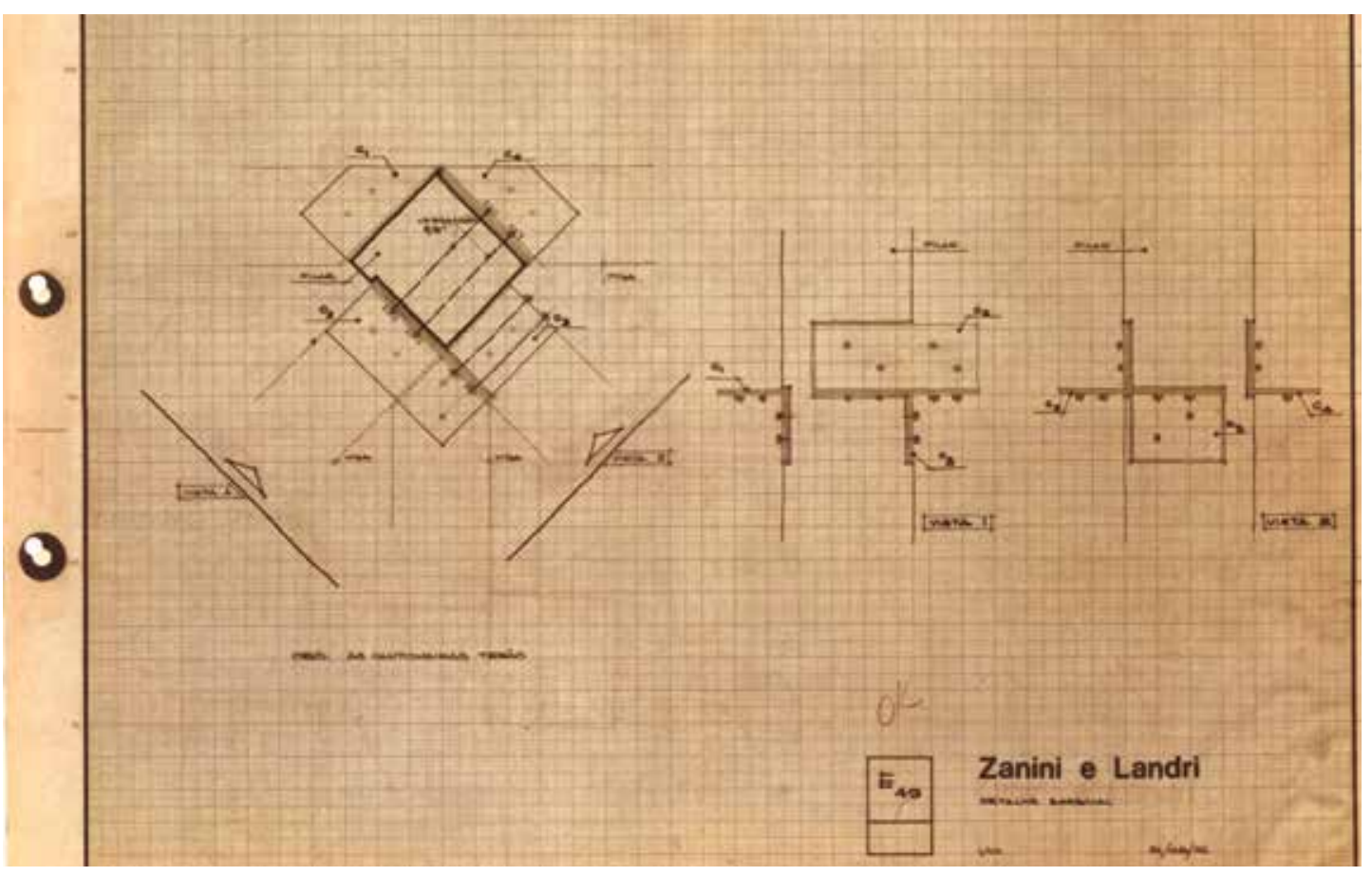

Figura 80. Encontro viga e pilar. Desenho de 1976. Fonte: Ivan do Valle. 
Já está tudo anotado. Ai chega lá, no destino que ia a casa, ai conseguia montar pela numeração. (SILVA, depoimento de 17/08/2017)

Hélio Olga descreve a numeração como sendo "...um quadradinho de aço e aqui tem a letra, o número. Então, por exemplo, ele marcava aqui a posição e riscava. Aí ele marcava 1 aqui, 1 na viga e 1 no caibro. 2 na viga e 2 no caibro. E você procurava e punha no lugar certo".

Muitas vezes montavam mais de uma casa ao mesmo tempo. Com o auxílio do manual de cada casa e da numeração que faziam nas peças, não havia confusão:

A gente primeiro fazia o quadro direitinho, depois colocava as colunas. E as colunas tinham uma cantoneira embaixo de ferro. Tipo um esquadro. Assim, assim e assim. E ai colocava direitinho. Se precisasse, meio centímetro. E dai em cima travava. Mas em baixo tinha as cantoneiras. E ai começava $A 1, A 2, A 3, A 4, A 5$, até quantas colunas tivesse. E ai vinha a B, entendeu? B1, B2, B3, B4. Até... Não mudava. Se era um número era um número com aquela quantidade. E ai no manual a gente não perdia, quando fosse montar lá. Por exemplo, se uma casa tivesse 20 colunas, era só $A$. Outra casa tivesse 30 colunas, era só B. Porque era para não errar. (BARROS, depoimento de 19/08/2017)

Depois de numerarem a casa, desmontavam-na, colocavam a estrutura no caminhão, que era carregado primeiramente com a estrutura do telhado e com as vigas superiores, depois com os pilares e, por último, com as vigas inferiores. A viagem, que era longa, ajudava na secagem das peças de madeira.

Quando as peças chegavam no terreno onde seriam montadas, a fundação já estava preparada e era igual à de Nova Viçosa, com o mesmo espaçamento:

Era, por exemplo, a casa tá aqui. Ai tirava todas as medidas e fazia a base lá. Aonde [SIC] a gente ia montar. O pedreiro lá fazia. Por telefone. Pra quando levasse os quadros da casa, já tá tudo certinho. E todas as casas que saiam daqui, as bases estavam esperando, tudo naquela continha, consoante às daqui. Só não definia algum detalhe por dentro da casa, mas o quadro geral, ia certinho. (BARROS, depoimento de 19/08/2017)

Estando com a fundação pronta, o caminhoneiro descarregava, junto com os trabalhadores da obra, primeiro as peças que foram carregadas por último, as vigas inferiores, que já eram apoiadas na fundação. Depois descarregava os pilares, que também já eram montados. Precisava-se prever um local, no terreno, para deixar as vigas superiores e a estrutura do telhado, que seriam montadas posteriormente.

Quando questionado sobre a proteção da madeira contra xilófagos, Caruana diz:

Na época usávamos pentaclorofenol, porque era autorizado. E depois do pentaclorofenol apareceu um produto industrial que se chamava Carbolineo, que era pentaclorofenol na verdade, mas que 


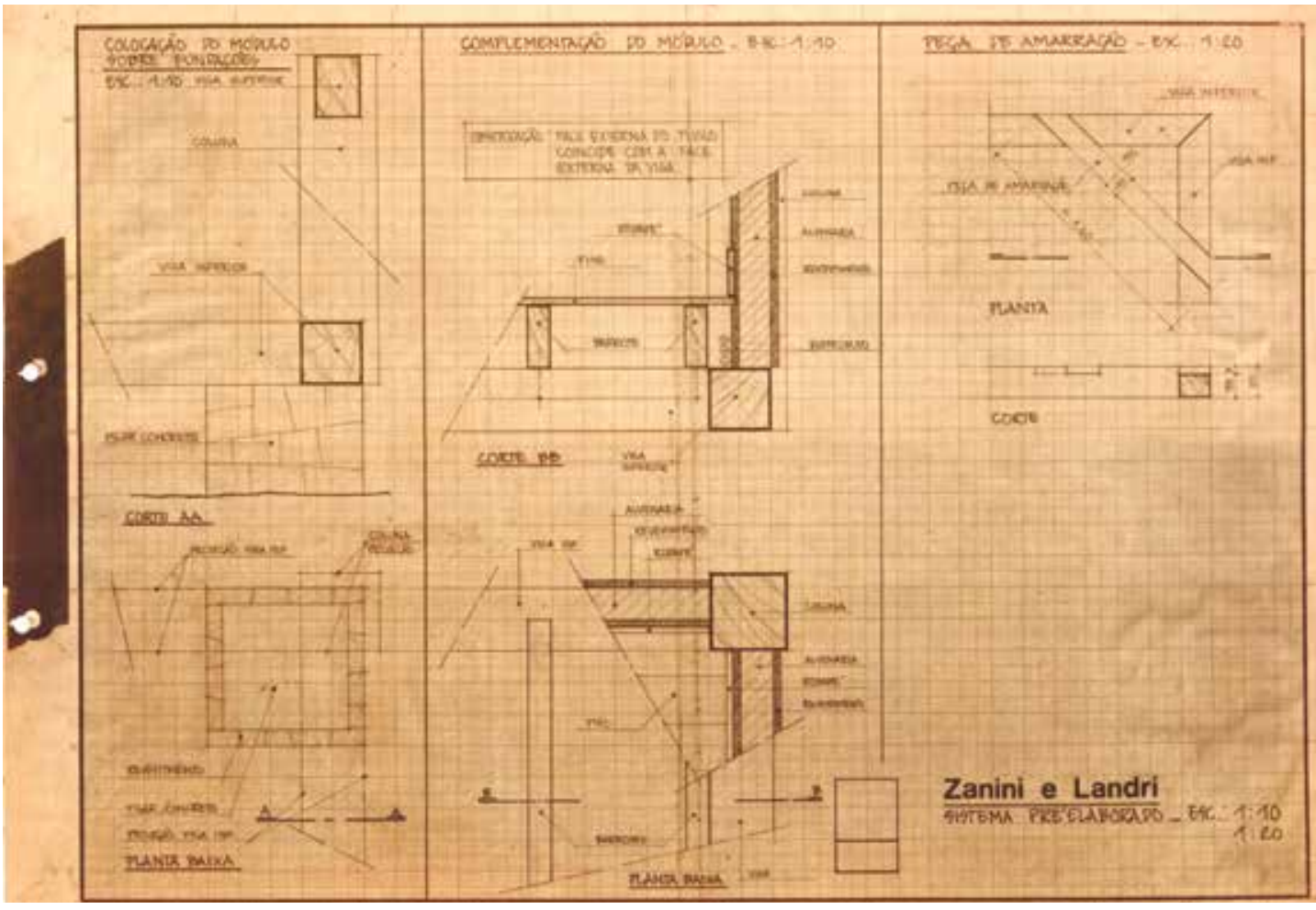

Figura 81. Montagem do sistema pré-elaborado. Fonte: Ivan do Valle.

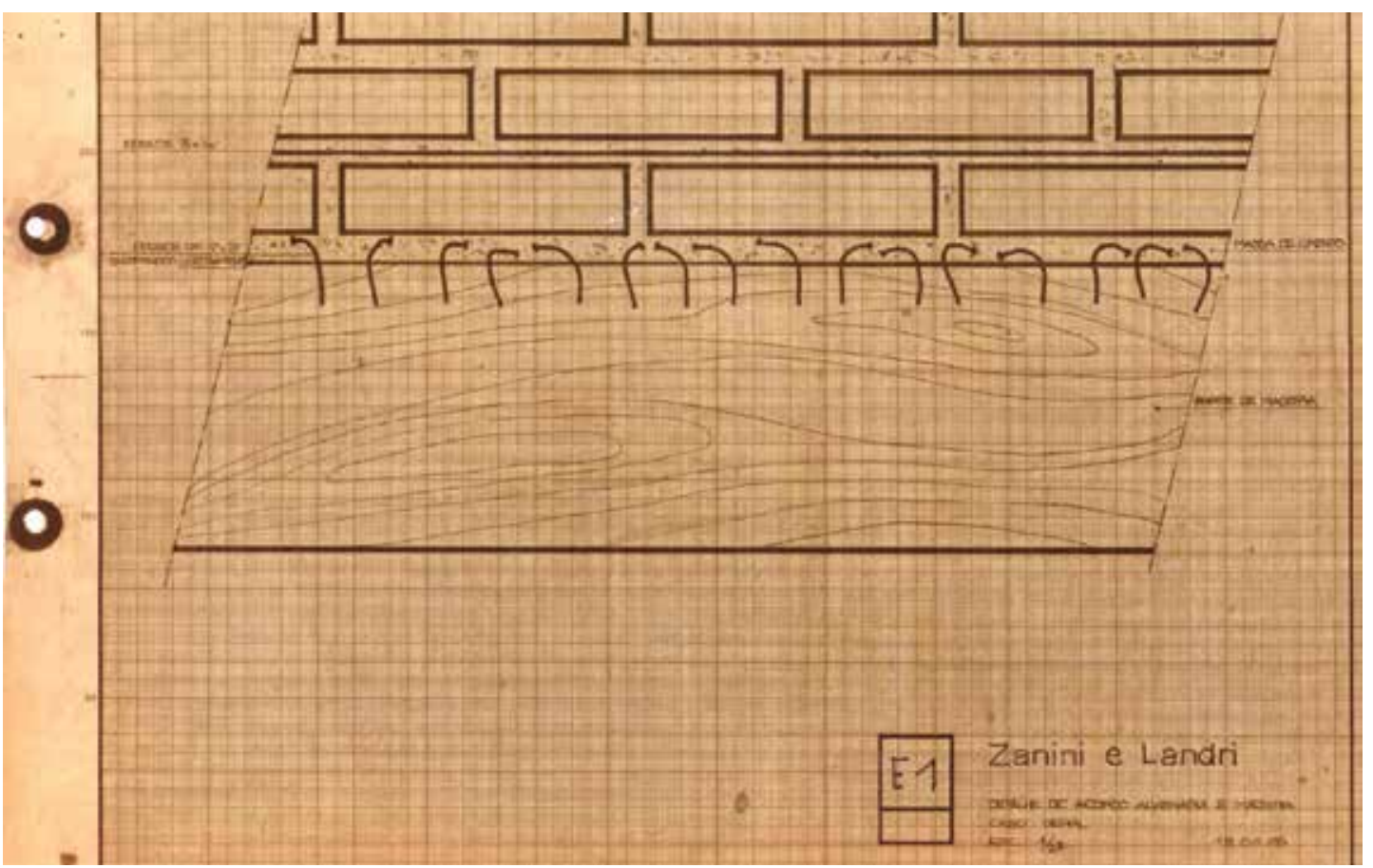

Figura 82. Encontro viga inferior e parede. Desenho de 1978. Fonte: Ivan do Valle. 
a gente diluia com querosene porque o querosene tornava a coisa muito menos viscosa, penetrando mais na madeira. Depois fomos descobrindo que, se a gente fizesse isso quente era melhor ainda. Deixávamos a lata no sol com o preparado de pentaclorofenol com querosene. O sol esquentava muito o galão de petróleo que a gente usava pra misturar, tornando a mistura mais penetrante. Isso a gente foi aprendendo com tempo. Em Nova Viçosa a gente fer. um pouco de tudo, até que a gente não fez mais nada, deixou natural. Porque, na verdade, se você tiver os detalhes construtivos bem feitos, você não vai ter problema. Se a sua madeira for bem selecionada, for puro cerne, o cupim não vai comer, na medida em que ela esteja ventilada. Cupim come quando a umidade permitiu o fungo de viver, o fungo extrair os taninos da madeira, a ausência de tanino na madeira, que era sua proteção natural, permite que o cupim faça festa. Porque se não, não existia floresta. Os cupins comeriam todas as florestas. Não come porque a madeira tem a sua defesa, são os taninos. Quando você corta a madeira e ela morre, os taninos ainda estão lá. O fungo é muito responsável por tirar os taninos. Então primeiro vem o fungo e tira os taninos. E depois vem o cupim e faz a festa. (CARUANA, depoimento de 25/11/2016)

O depoimento de Caruana é confirmado pelo do engenheiro Hélio Olga, que afirma que Zanine não passava nada para proteção das casas.

Não fazia nada. A gente não pintava, a gente não fazia nada. Isso é uma baita de uma discussão. Porque, assim, na madeira densa, você não tem ataque de inseto no cerne. Você vai ter, no geral, no brancal. As peças dele praticamente não tinham brancal. Você pode passar um Pentox, alguma coisa dessa, mas eu não lembro, em nenbuma casa dele, de ter tido problema de cupim, de madeira seca. O problema são as peças que ficam em contato. Por exemplo, o pilar, nessa casa que você vai visitar. (OLGA, depoimento de 02/02/2017)

Zanine parou de fazer essas casas em 1980, e em 1984 retornou para Brasília. Segundo Ivan do Valle, falando sobre uma das possibilidades da volta de Zanine para Brasília:

Creio que o motivo da mudança do Zanine para Brasilia tenha sido a junção de vários fatores que aconteceram nessa época. A ditadura tinha recém terminado e o novo governador de Brasilia, José Aparecido, era amigo particular de Zanine. O então reitor da UnB, Cristovam Buarque, reintegrou vários professores que foram exilados nos anos de "chumbo", dentre eles Oscar Niemeyer, Zanine, José Humberto etc. Esse cenário era espetacular para Zanine e ele vislumbrou uma boa oportunidade de retornar à capital para realizar alguns sonhos. (VALLE, depoimento de 09/06/2016)

Somado a isso, acredita-se que a desilusão com a falta de interesse político em dar continuidade ao seu projeto urbanístico, artístico e social para Nova Viçosa fez com que Zanine mudasse seus planos de permanecer na cidade. Com o fim da gestão de Tânus Correia das Neves, que apoiara o projeto urbanístico de Zanine, trocando-o por algumas glebas, iniciou-se a gestão de Abraão Soares Pereira, que não deu continuidade ao projeto. 



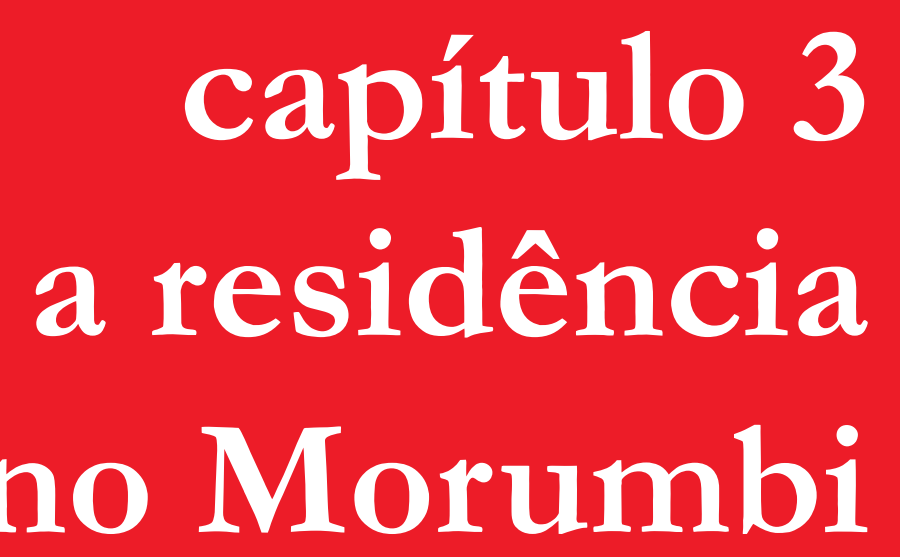





\section{a residência no Morumbi}

Este capítulo está dividido em 3 partes, a primeira trata da construção da casa do Morumbi no seu terreno definitivo em São Paulo, parte na qual dissertaremos sobre os encaixes presentes na casa e descreveremos a sua montagem. A segunda apresentará o programa da casa do Morumbi. A terceira falará das relações construtivas entre as técnicas usadas no sistema pré-elaborado e técnicas de algumas construções tradicionais do Brasil.

Feita em Nova Viçosa de acordo com o sistema pré-elaborado, em que as casas eram inicialmente fabricadas acima do piso quadriculado da oficina de Zanine, sendo depois desmontadas e enviadas para o seu terreno definitivo, no qual a fundação já estava pronta e distanciada conforme modulação utilizada para construção da estrutura em Nova Viçosa, essa residência foi enviada para o bairro do Morumbi, em São Paulo.

Em 1980 Hélio Olga se casou. Nessa época estava montando duas casas pré-elaboradas em São Paulo e decidiu encomendar a Zanine uma terceira para seu uso próprio.

Por trabalhar a partir da modulação do piso na sua fábrica em Nova Viçosa, Zanine iniciava seus projetos pela planta baixa, depois passava para as vistas. Como de costume, usava papel milimetrado e canetinhas coloridas e foi assim que apresentou a sua proposta de projeto, seguindo programa fornecido por Hélio (f.83).

A partir de conversas entre os dois, decidiram fazer algumas modificações na planta original. Essas modificações podem ser vistas feitas a lápis, na mesma folha onde está o projeto de Zanine.

O terreno escolhido é inclinado, e a implantação da casa segue solução normalmente utilizada por Zanine: mexer o mínimo possível no terreno, suspendendo parte do piso da casa através de pilares, formando um plano elevado no qual o programa da casa se desenvolverá. Sendo assim, a casa foi implantada na cota mais alta do terreno. Como a entrada fica na cota mais baixa, ela avança a entrada da casa, formando uma praça coberta que é usada como garagem e entrada para o subsolo da residência.

Plasticamente, a fachada de acesso tem um equilíbrio presente pelo eixo de simetria de cheios e vazios, resultado formal do programa que reflete nesta frontalidade: a sala de TV e a varanda. Além disso, a repetição de elementos como os caibros, espaçados a cada 

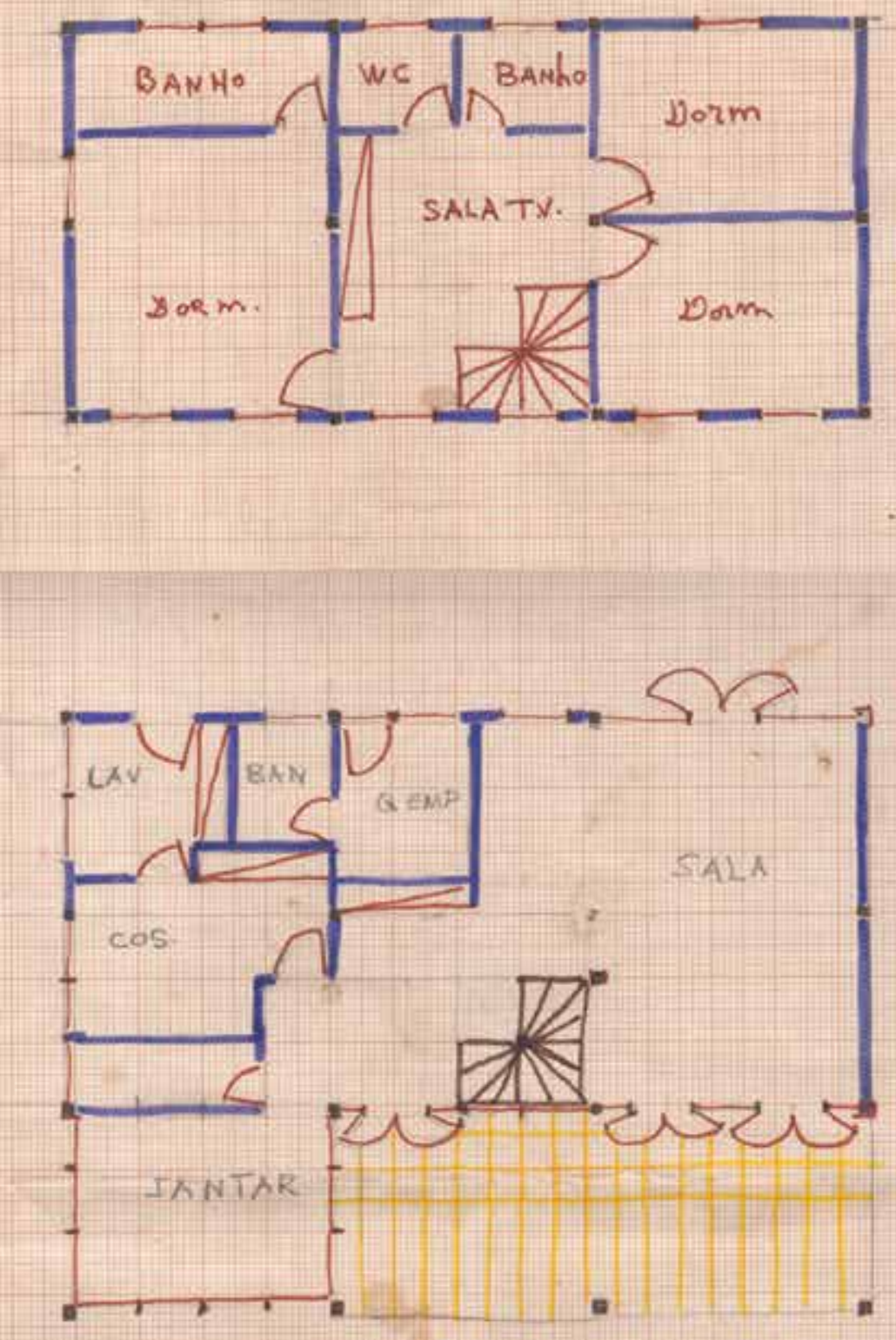

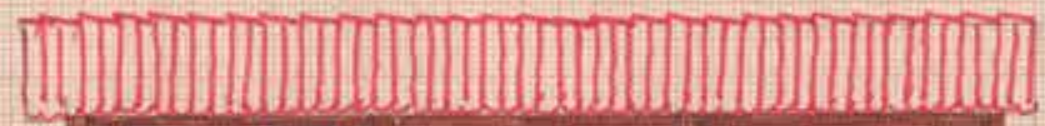
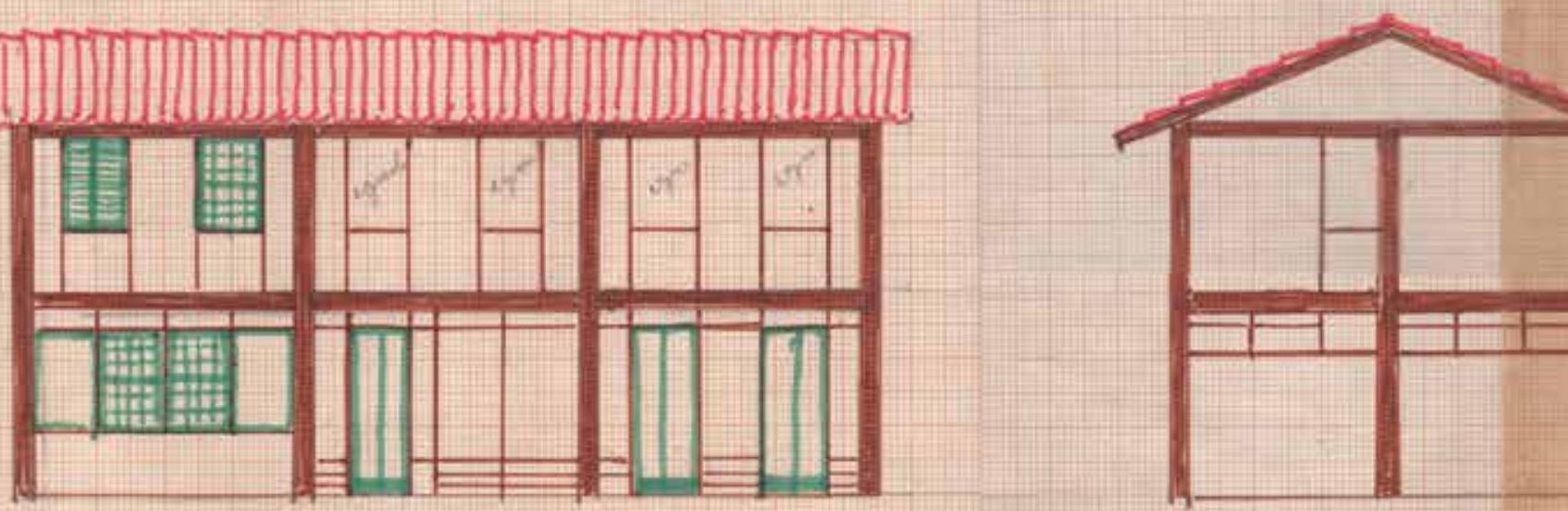


$$
\begin{aligned}
& \text { live umi eopin } \\
& \text { me dovolya } \\
& M \text { tQ }
\end{aligned}
$$

do Sour

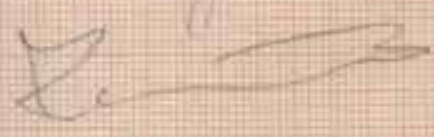

44
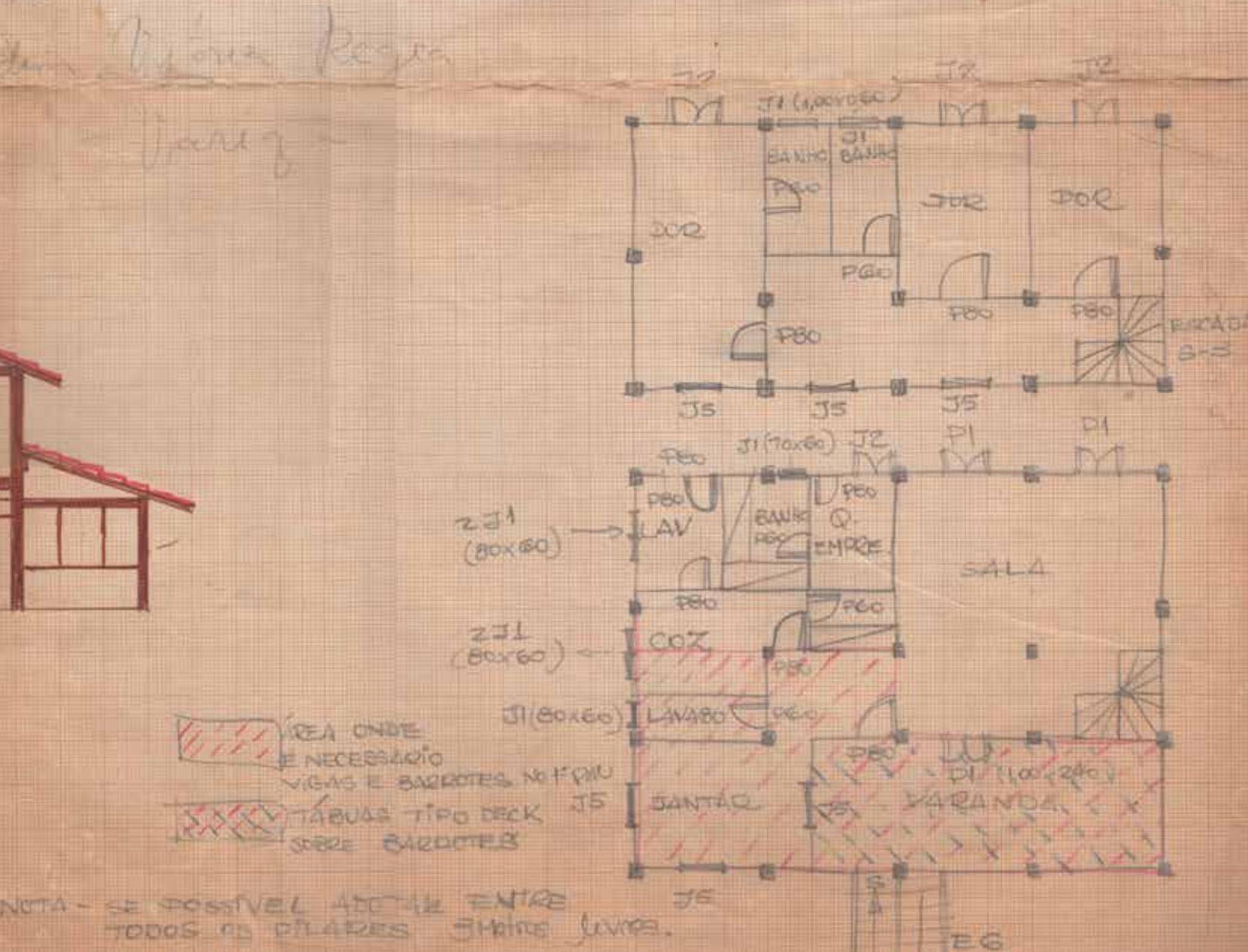

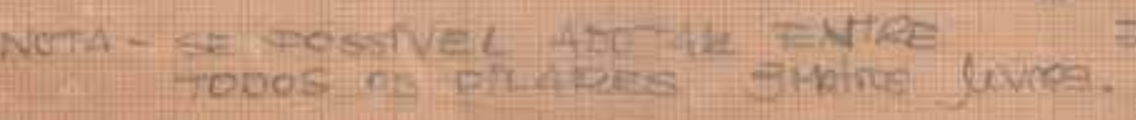

EEA ONDE
ENECESSLRIC

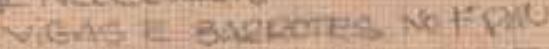

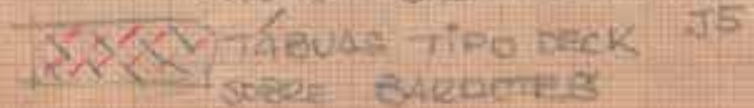


Figura 83. Páginas 32 e

33, planta da casa feita por

Zanine. À esquerda e à lapis,

modificação posterior. Fonte:

acervo pessoal de Hélio Olga.

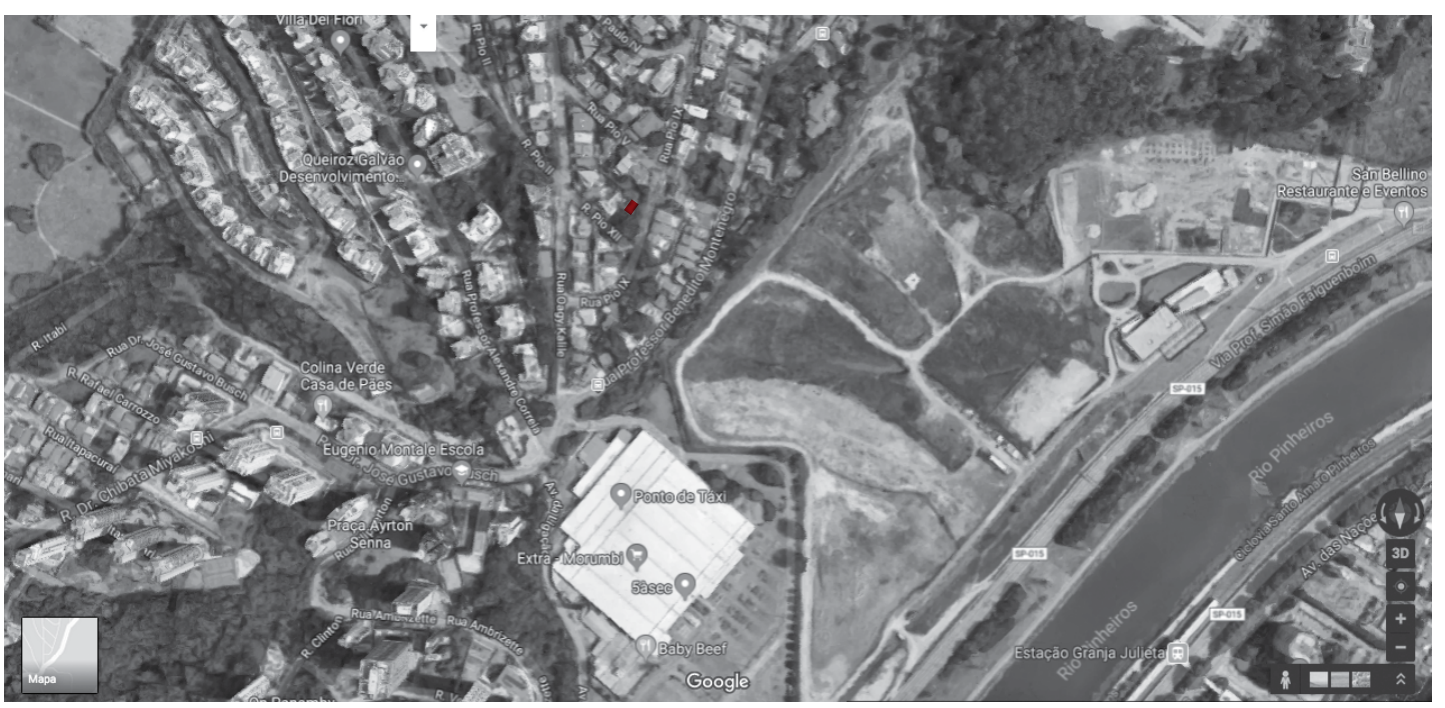

Figura 84. Localiz̧ação da residência. Fonte: google maps.

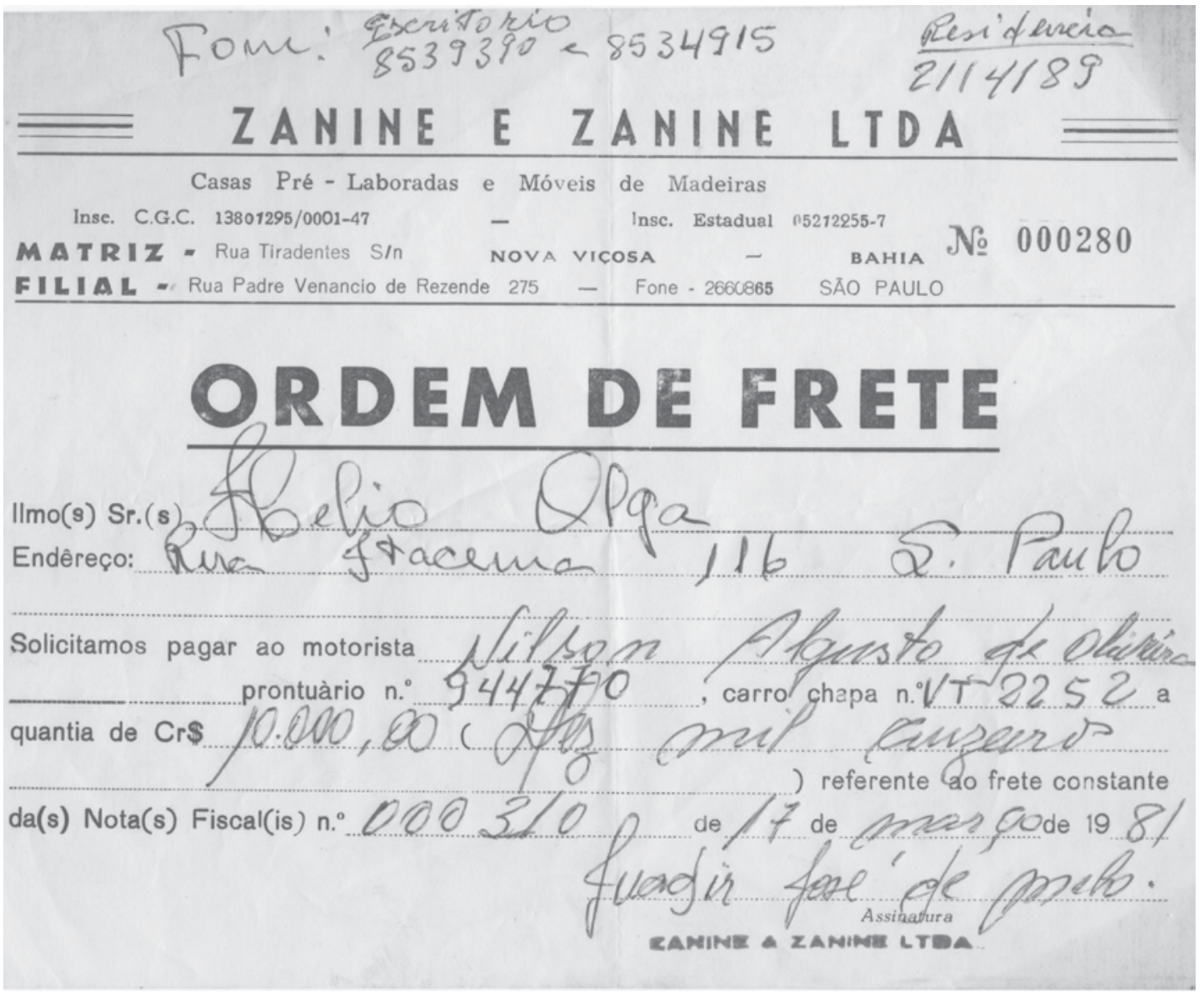

Figura 85. Ordem de frete da casa do Morumbi. Fonte: acervo pessoal de Hélio Olga. 
$50 \mathrm{~cm}$, e do ritmo das aberturas, confere à fachada equilíbrio e harmonia, compondo com a modulação dos painéis de janelas, que possuem 1 metro de largura, e da estrutura da casa feita a partir de módulos de $3 \mathrm{~m}$ x $3 \mathrm{~m}$, um sistema construtivo.

O sistema construtivo da casa pode ser observado olhando a sua fachada: vemos 5 pilares de madeira, apoiados sobre a viga inferior de sustentação da casa. Esses pilares estão espaçados a cada $3 \mathrm{~m}$. Os caixilhos têm $1 \mathrm{~m}$ e podemos ver a frente dos caibros, espaçados a cada $0,5 \mathrm{~m}$ A viga inferior tem aproximadamente $9 \mathrm{~cm}$ de largura por $29 \mathrm{~cm}$ de altura. O pilar tem seção de $24 \mathrm{~cm}$ x $24 \mathrm{~cm}$ e os barrotes têm $7,5 \mathrm{~cm}$ x $15 \mathrm{~cm}(\mathrm{LxA})$. É importante ressaltar que estas dimensões variam de acordo com o clima, retraindo em temperaturas frias e menos úmidas, como é o caso de São Paulo, quando comparado à Nova Viçosa, cidade onde a estrutura foi fabricada.

O sistema construtivo é o pré-elaborado, desenvolvido por Zanine. Para montagem da casa no terreno definitivo, inicialmente eram montados os módulos estruturais, que podemos imaginar como arestas formando um cubo, sobre a fundação existente.

As vigas inferiores são apenas apoiadas sobre a base de sustentação da casa, pilares de concreto com seção quadrada de $15 \mathrm{~cm}$, que fazem todo o contato com o terreno, deixando a madeira livre de umidade. O pilar é vinculado às vigas inferiores por cantoneiras metálicas, impedindo que essas peças se movimentem nos eixos x, y e z (f.90). Já os barrotes são apoiados em cima de estruturas pregadas nas vigas inferiores (f.91). Apoiado nos barrotes fica o piso, de tábua de madeira.

As paredes são sempre erguidas acima das vigas inferiores, não sendo uma planta livre. A viga superior tem aproximadamente $9 \mathrm{~cm}$ de largura por $29 \mathrm{~cm}$ de altura e muitas vezes não tem comprimento suficiente para atravessar toda a fachada da casa, fazendo com que duas peças sejam unidas por uma sambladura, chamada de "raio de Júpiter" ou "mão de amigo". Essa sambladura impede que as peças se distanciem longitudinalmente umas da outras quando tracionadas.

Zanine também utilizou essa sambladura para solucionar uma questão prática do préelaborado: o tamanho do beiral variava de projeto para projeto. Como tornar ele um item a ser adicionado na estrutura da casa? Zanine solucionou esse problema unindo o beiral à estrutura da casa através do encaixe "raio de Júpiter"(f.96), com suas dimensões variando de acordo com o projeto. Segundo Hélio Olga, o beiral podia ter entre 0,5m e 1,5m.

Outro detalhe construtivo muito utilizado pelo arquiteto é o "cachorro"(f.94), solução muito usada para diminuir o ângulo de inclinação do telhado, projetando a água proveniente da chuva mais longe das paredes, prolongando o beiral sem prejudicar a altura do pé direito e a iluminação. A dupla inclinação do telhado acabou se tornando uma característica marcante da arquitetura de Zanine. Os "cachorros" são arrematados de forma rústica, ficando aparente a seção da madeira pela fachada da residência, o que ajuda na compreensão da estrutura, ritmando a mesma.

A estrutura do telhado é independente da casa, colocada após a montagem do "cubo de madeira". A partir disso prolonga-se o pilar que sustentará a cumeeira da casa. Os caibros se encaixam, de um lado, na cumeeira, apoiando em uma madeira de 
Figuras 86, 87 e 88. Fotos

de construção da Casa no

Morumbi. Fonte: acervo pessoal de Hélio Olga.
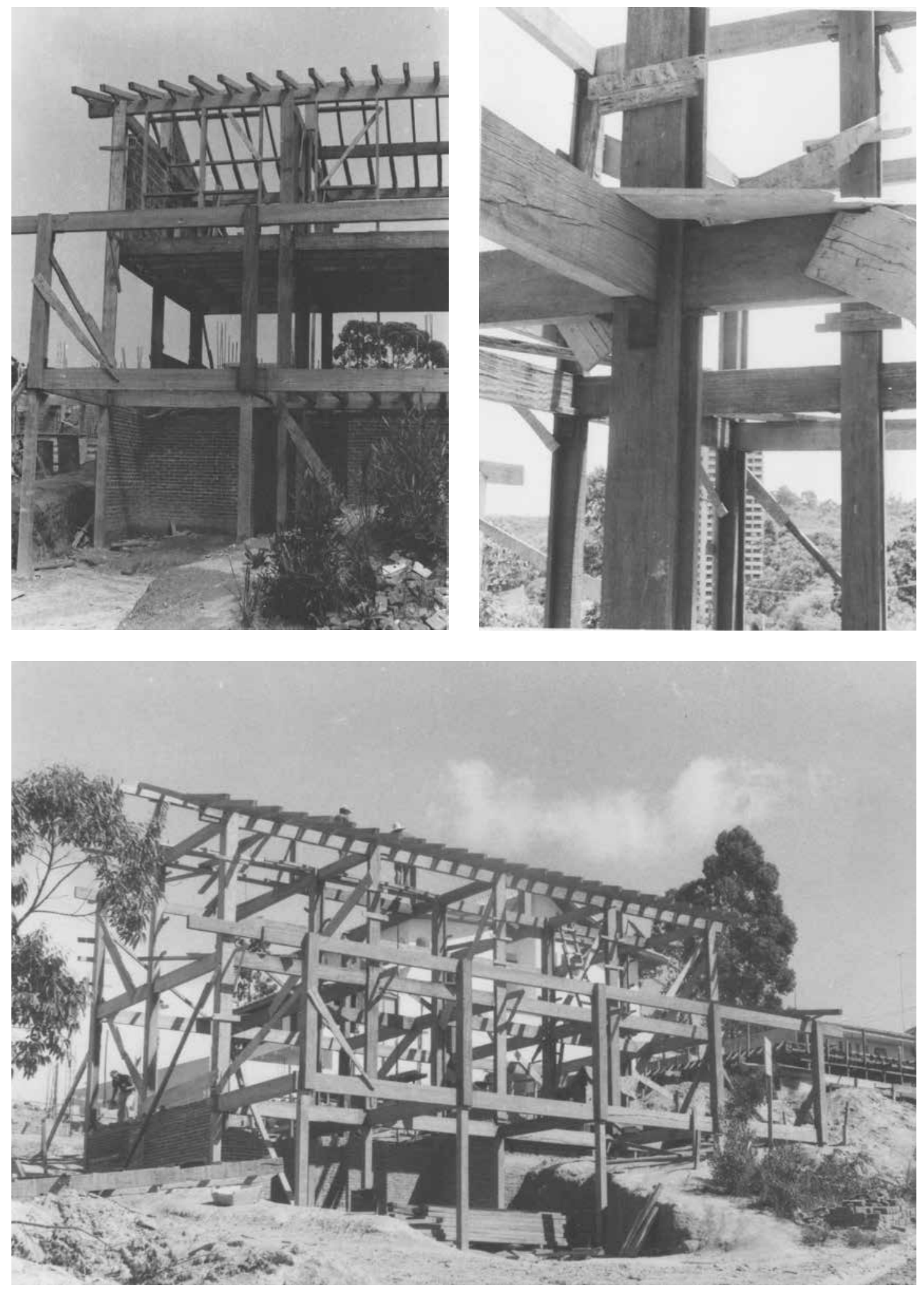

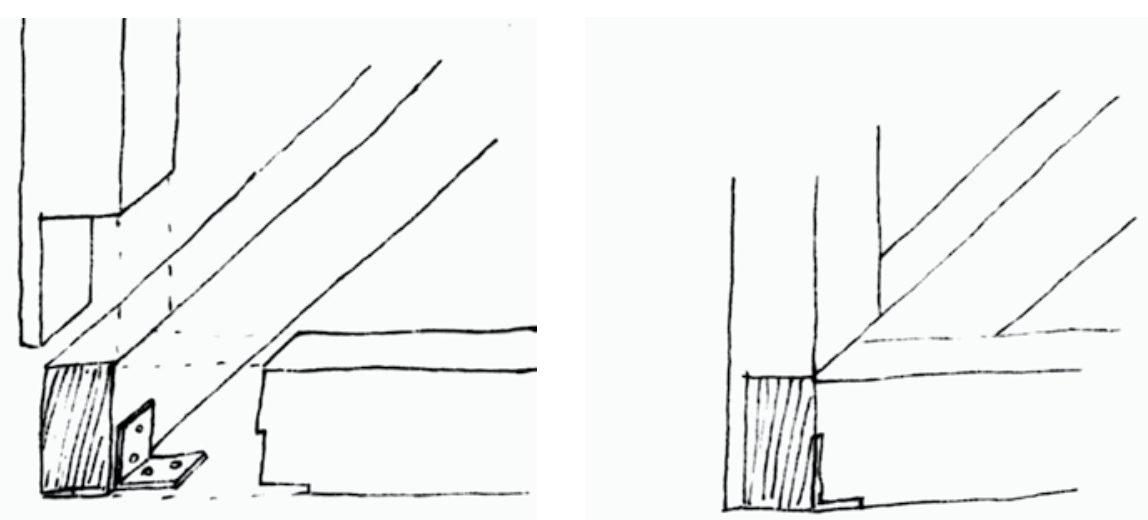

Figura 90. Encontro entre vigas inferiores e pilar, que se apoiam sobre fundação Fonte: Amanda Carvalho.
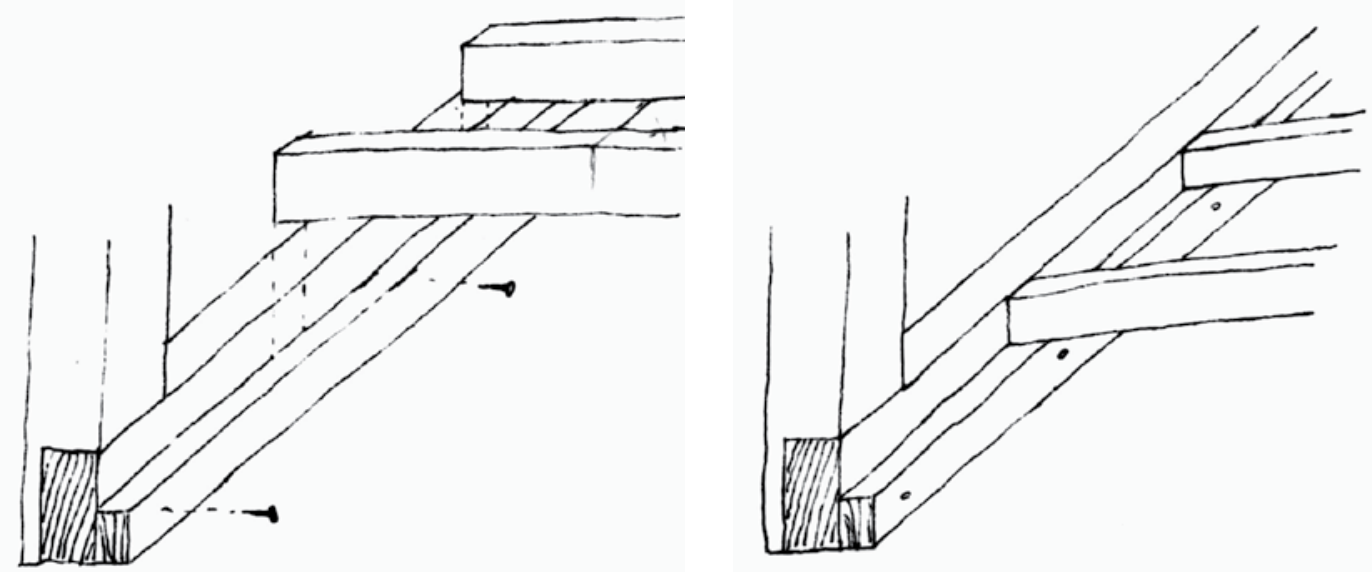

Figura 91. Colocação dos barrotes Fonte: Amanda Carvalho.

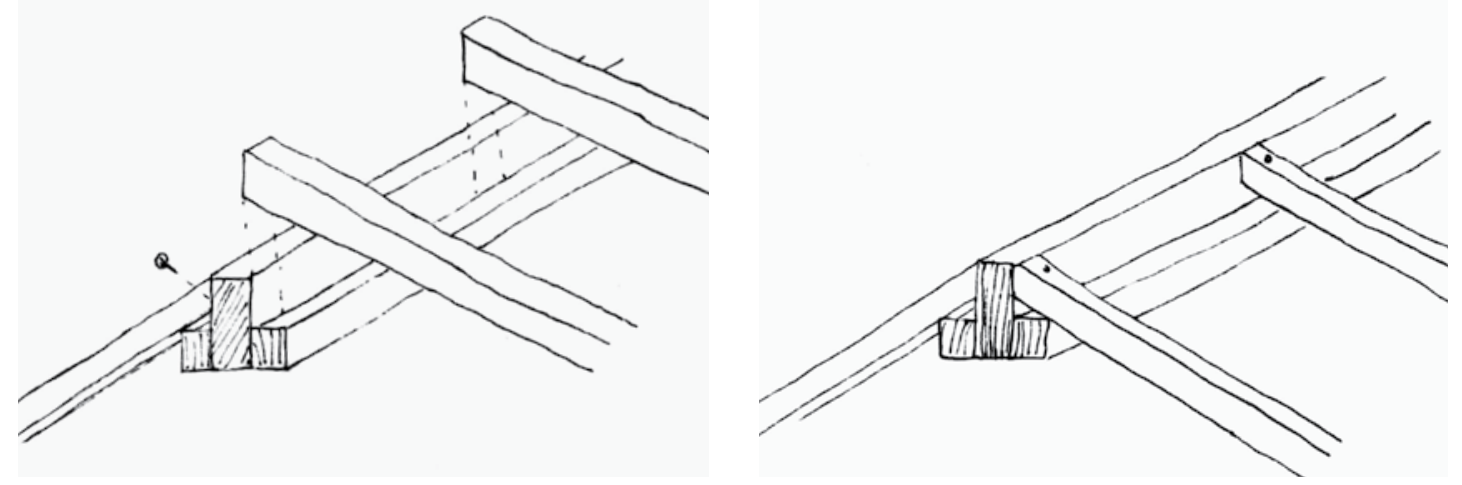

Figura 92. Colocação dos caibros. Fonte: Amanda Carvalho. 

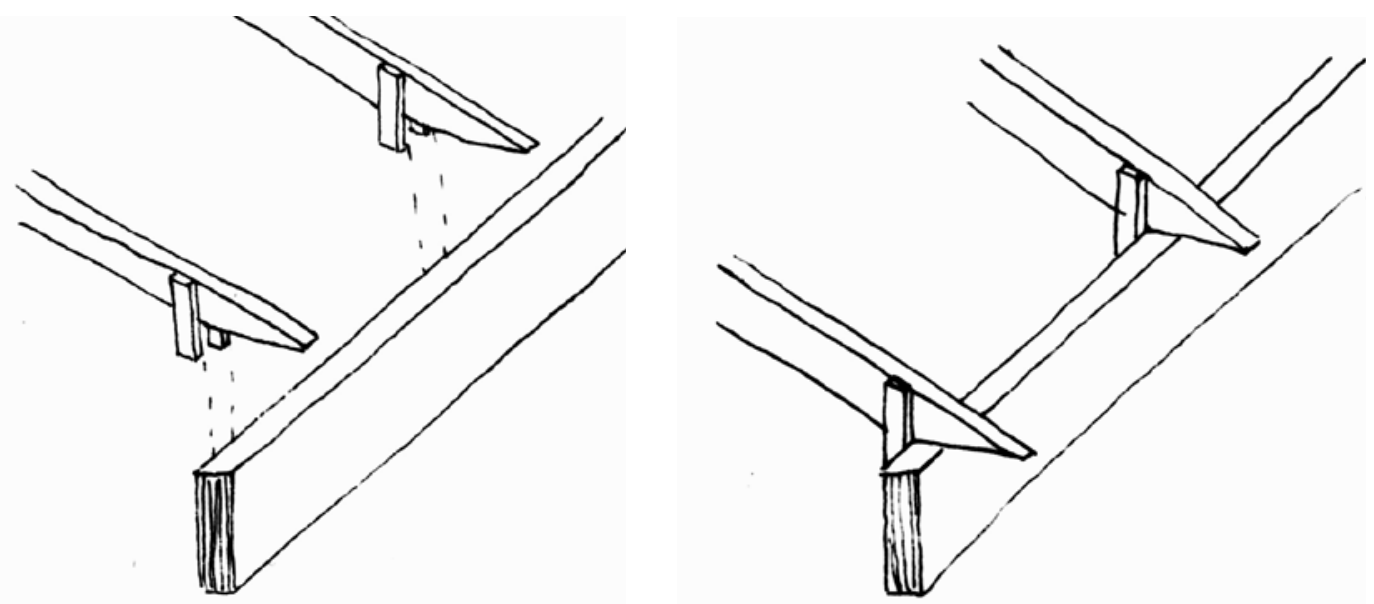

Figura 93. Encontro dos caibros com vigas superiores. Fonte: Amanda Carvalho.

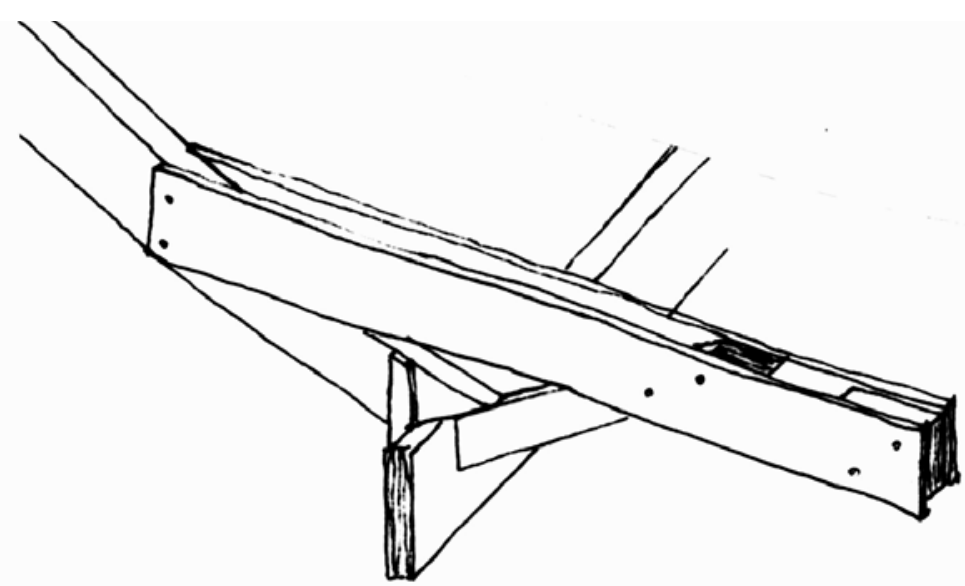

Figura 94. Cachorro. Fonte: Amanda Carvalho.
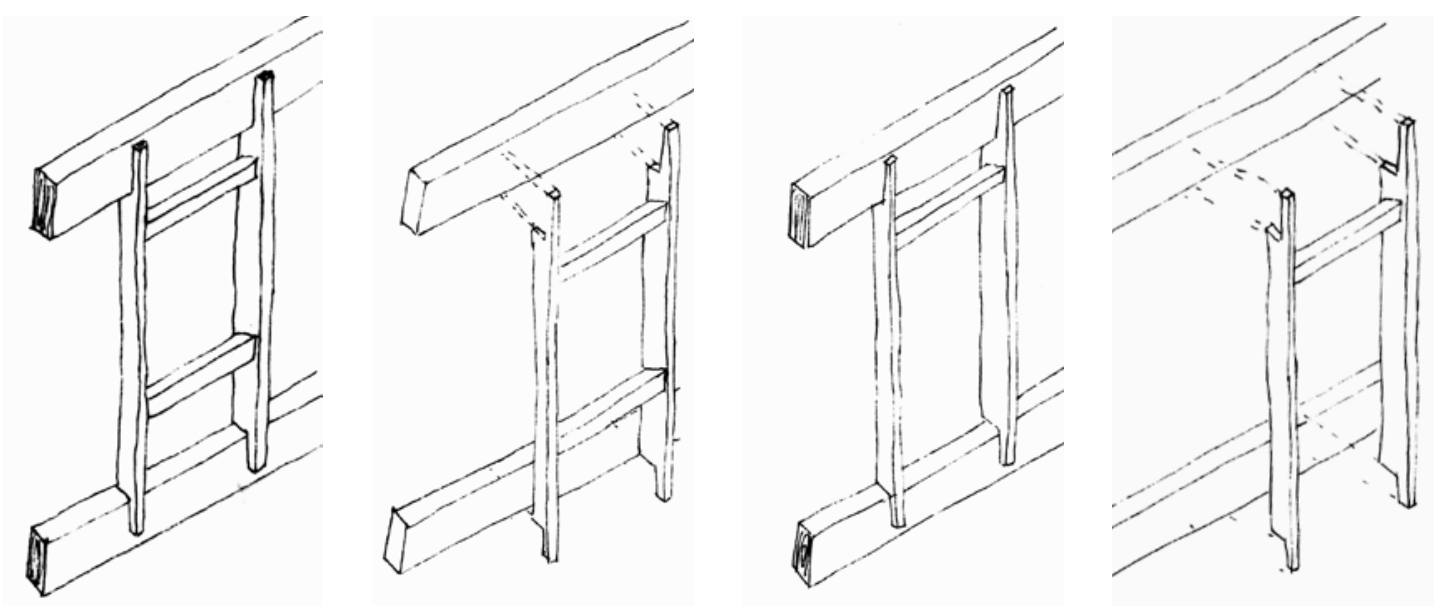

Figura 95. Estrutura de janelas e portas presas nas vigas inferiores e superiores. Fonte: Amanda Carvalho. 

Figura 96. Raio de Júpter.

Fonte: acervo pessoal de

Amanda Carvalho, fotografia

de Rafaela Netto.

sustentação que está pregada nela, do outro lado, na viga superior do cubo estrutural (f.93). Para travar o caibro de movimentar-se horizontalmente há dois pequenos pedaços de madeira pregados nele. Dessa forma o caibro empurra a estrutura da viga na qual apoia, que não abre por ter uma outra viga, perpendicular a ela, segurando essa força.

Os forros são de madeira nos cômodos dos cantos do andar superior, acompanhando a inclinação do telhado. Na cozinha e no banheiro social do térreo, o forro é plano e de madeira aparente, fica abaixo dos barrotes, deixando o pé-direito com 2,35m. Já nos banheiros do andar superior, o forro é branco, provavelmente de laje.

$\mathrm{Na}$ sala podemos ver os baldrames de sustentação do piso superior; acima deles há um forro branco, destacando e ritmando a estrutura do piso, de madeira escura e distanciada a $50 \mathrm{~cm}$ uma do outra. De acordo com Hélio, esse forro branco foi feito da seguinte forma:

Furamos os barrotes e fizemos uma armação com ferro $5 \mathrm{~mm}$ formando uma malha de mais ou menos $15 \times 15 \mathrm{~cm}$. Colocamos uma forma $5 \mathrm{~cm}$ abaixo da face superior do barrote e concretamos. $O$ assoalho está preso diretamente nos barrotes. O acabamento é pintura direto no concreto. (informação pessoal) ${ }^{1}$

A casa tem um grande telhado de duas águas e um telhado de uma água só, cobrindo a varanda e a sala de TV. Ambos têm telhas de barro capa-e-canal.

Como a umidade é um problema para estruturas de madeira, percebe-se o cuidado em sempre deixar a alvenaria avançar em relação às vigas que estão abaixo delas, não permitindo que acumule água nesses pontos.

Há quatro tipos de portas na casa: portas venezianas; porta de correr com estrutura de madeira e quadrícula de madeira que sustenta vidros; portas simples com tábuas sambladas umas às outras através de encaixe macho e fêmea e unidas por travessas; e portas que, apesar de também serem sambladas umas às outras através de encaixe macho e fêmea e unidas por travessas, diferenciam-se do tipo anterior por serem esculpidas com o enxó.

As portas são módulos presos na estrutura de madeira da casa através dos seus montantes verticais (f.95), que afinam ao encontrar a viga superior, adquirindo o formato de L que é pregado à viga.

Há dois tipos de caixilho, um deles é composto por duas folhas do tipo "guilhotina", fixadas às vigas superiores pelos seus montantes verticais, que formam um L, assim como o suporte das portas, para se adaptar à viga superior. A folha superior é fixa e a inferior corre por trás dela, impedindo que a água da chuva entre. Cada folha é composta por requadro de madeira, formando um quadriculado que suporta 3 linhas de 4 vidros cada. Esses caixilhos são modulados, possuem $1 \mathrm{~m}$ de

1 Mensagem recebida pela pesquisadora por meio de seu correio eletrônico em 23/01/2018. 
Figura 97. Fachada da

residência do Morumbi. Fonte:

acervo pessoal de Amanda

Carvalho, fotografia de

Rafaela Netto.

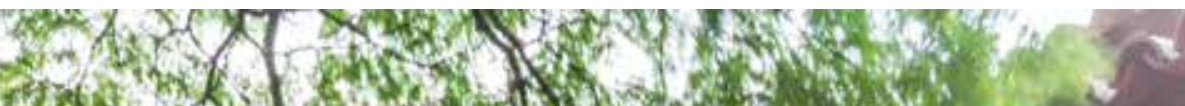

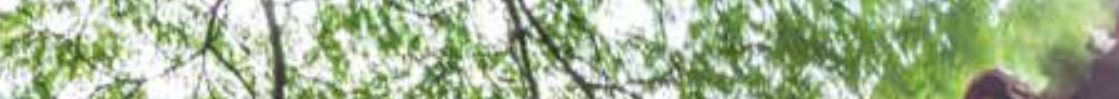

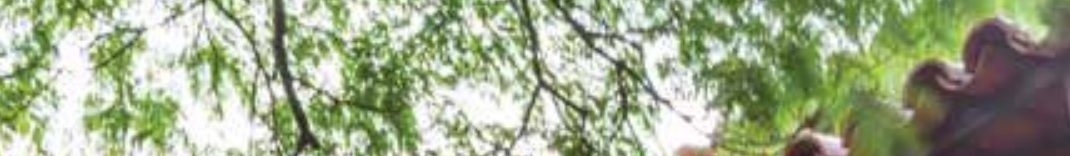

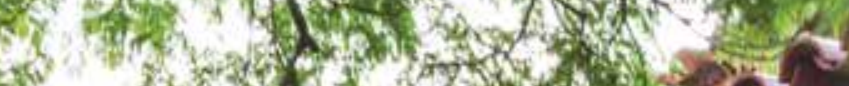

I.

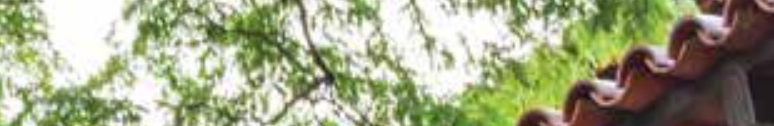

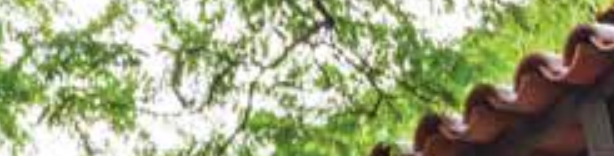

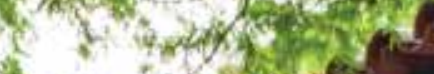

$x+2 x=6$

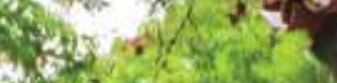

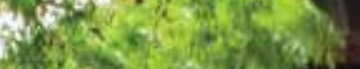

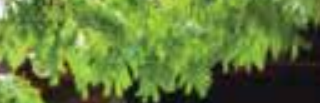

1 
largura; são presos à estrutura da casa pelo montante vertical, que vai da viga inferior até a superior, quando reduz sua espessura na junção com a mesma, assim como acontece com as portas.

O segundo tipo de caixilho é dividido por 3 montantes horizontais. No primeiro um terço, temos um vidro fixo. No segundo, uma madeira que bascula a partir de um pino central. Além disso, a casa possui painéis fixos de vidro que ficam em estruturas muito semelhantes às da janela guilhotina, com montantes que vão da viga inferior até a superior.

A casa é totalmente construída a partir de módulos. O menor deles é o metro, baseado na modulação do piso que existia em Nova Viçosa. A partir deles, temos os módulos estruturais, que formam os cubos de madeira no espaço. No caso desta residência, temos módulos de $3 \mathrm{~m}$ x 3m, formando 3 linhas de 4 módulos cada.

Ao analisar esta residência, percebe-se que Zanine quebra essa modulação na sala, deixando um corredor de $2 \mathrm{~m}$ x $3 \mathrm{~m}$ e uma sala com $4 \mathrm{~m} \times 3 \mathrm{~m}$. Isso provavelmente acontece para melhor adequar o programa, deixando uma sala mais espaçosa, sem pilares, e também para sustentar a parede do andar superior, deixando os quartos com $3 \mathrm{~m} \times 4 \mathrm{~m}$, dimensão mais generosa para um quarto do que se ele tivesse $3 \mathrm{~m} \times 3 \mathrm{~m}$.

Essa característica da casa é muito interessante, pois demonstra que Zanine aproveita a modulação em todo o seu potencial, mas não a deixa atrapalhar a construção do vazio, do espaço e dos cômodos.

A casa foi inteira produzida em Nova Viçosa e montada em São Paulo. Todas as escadas e janelas vieram de lá e praticamente todas as portas, com exceção das venezianas, que segundo Hélio Olga (02/02/2017) foram compradas em São Paulo.

Ainda segundo depoimento de Hélio Olga, algumas das dificuldades na montagem dessas casas vinham da irregularidade das peças de madeira. Os pilares na maioria das vezes estavam tortos, como descreve Hélio:

Só que os pilares eram bananas. Ai ele usava uns pilares que eram assim, uma pẹa aqui e duas tábuas, entendeu? Isso era um pilar de canto. O pilar de meia era isso aqui. E quando a viga entrava o pilar do meio não tinha continuidade, entendeu? Então você tinha uma certa elasticidade para prumar, mas às vezes o pilar vinha assim [fez o gesto de um pilar bem torto]. Entendeu? Então o que a gente fazia? A gente montava o primeiro andar, travava bem, puxava o segundo andar no tifor e alinhava. A gente botava um pilar contra o outro. E isso era um problema. Aliás, um problema que perdurou... Só com o laminado colado que acabou. Enquanto eu trabalhei com madeira nativa eu tive esse problema. (OLGA, depoimento de 02.02.2017)

Outro problema que acontecia por usarem madeira maciça é que a seção da mesma varia com a mudança de temperatura, umidade e vento dos lugares. Sendo assim, os pilares que eram de $25 \times 25 \mathrm{~cm}$ ficaram com $24 \times 24 \mathrm{~cm}$. 
Figura 98. Detalhe da junção de pilares e vigas através das cantoneiras. Fonte: acervo pessoal de Ivan do Valle.

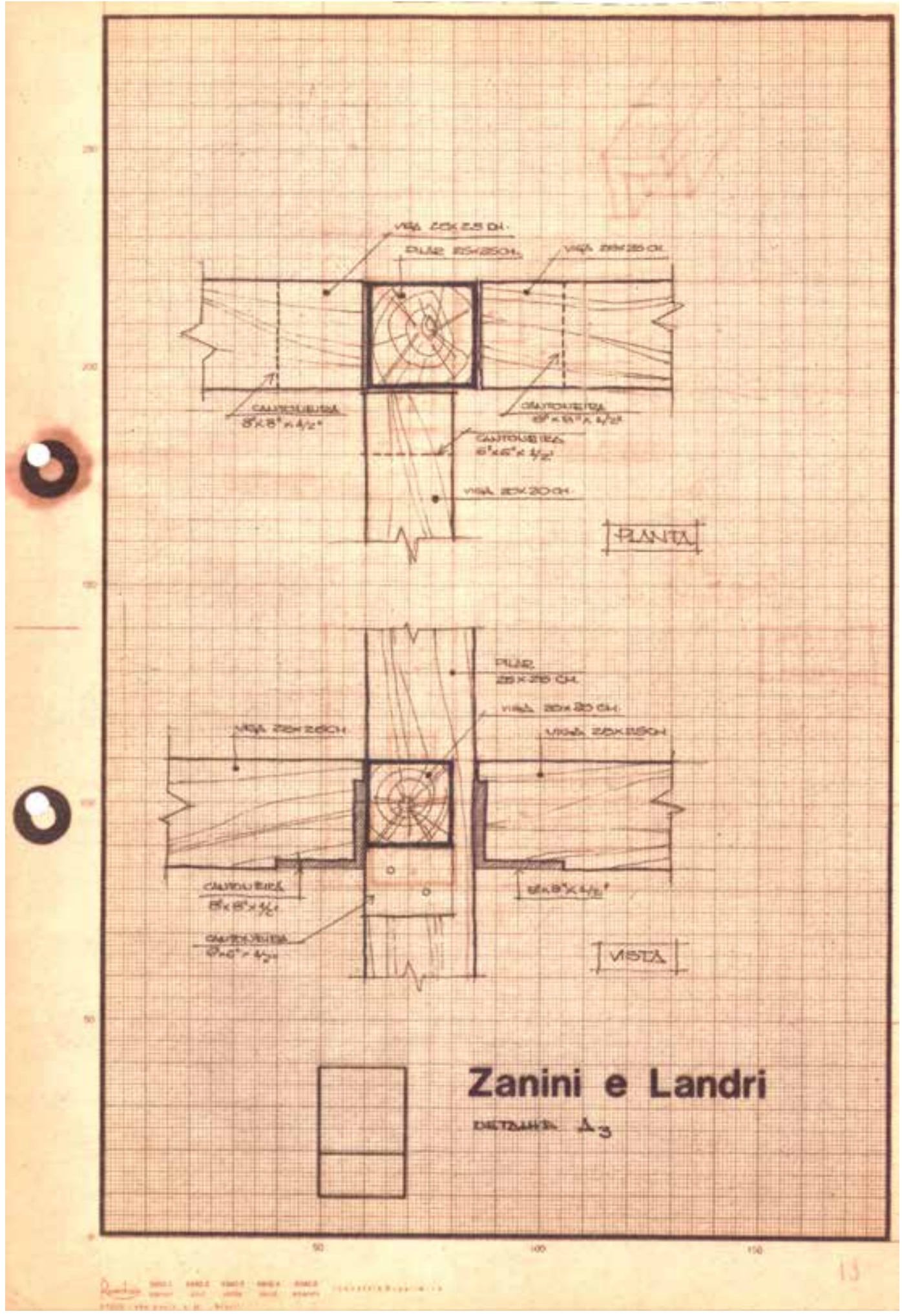


Figura 99. Detalhe da junção

de pilares e vigas através das

cantoneiras. Fonte: acervo

pessoal de Ivan do Valle.

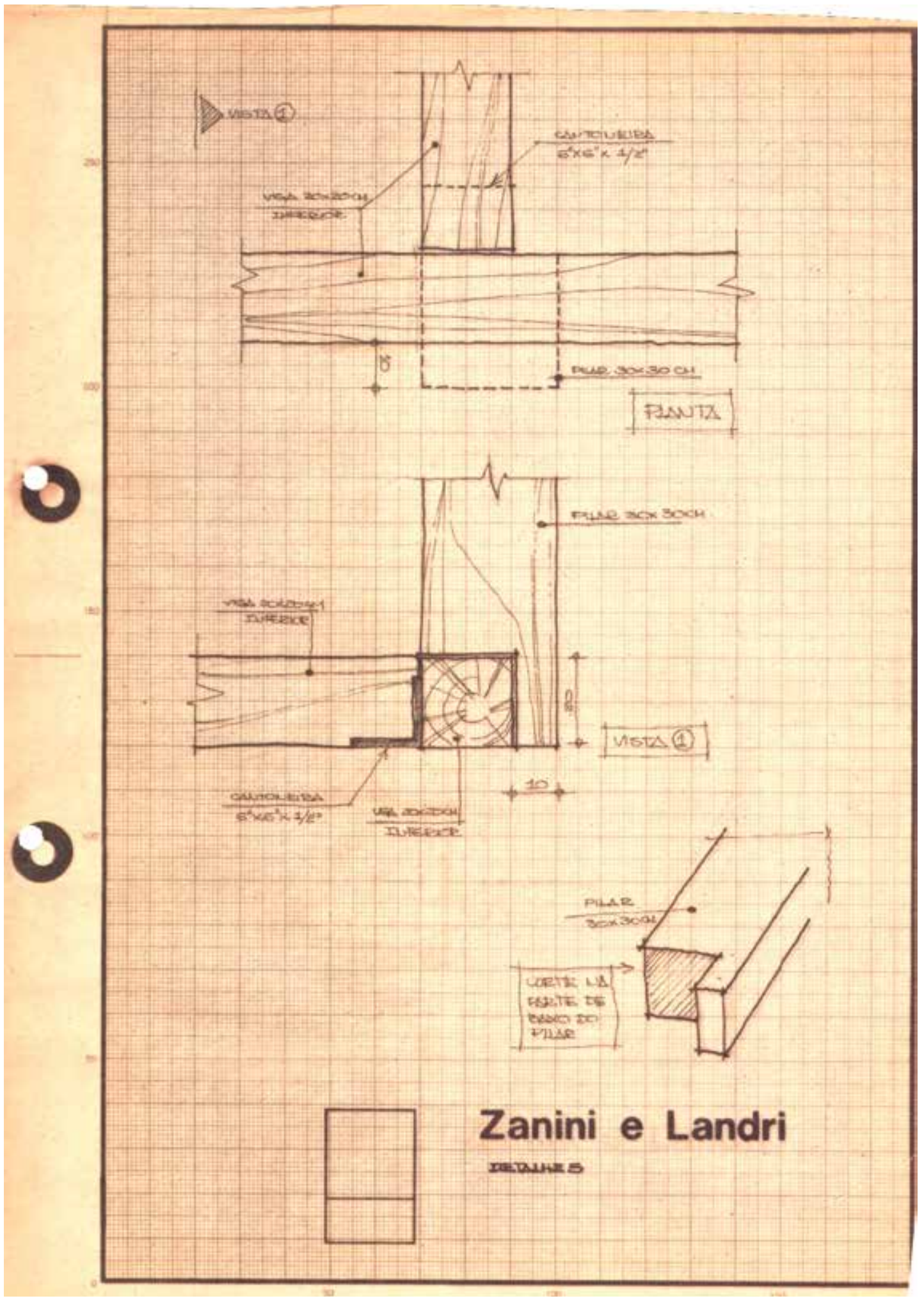




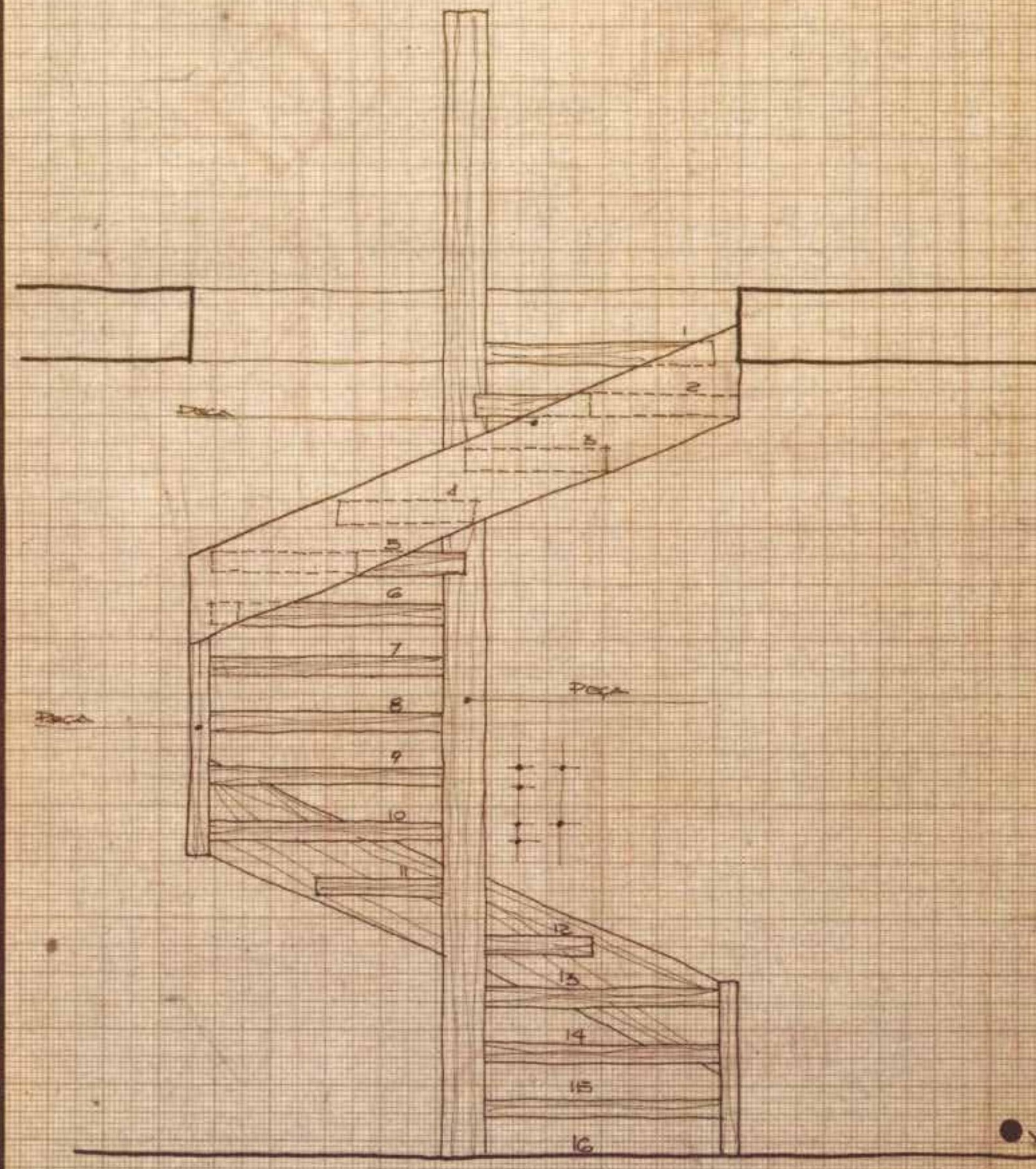




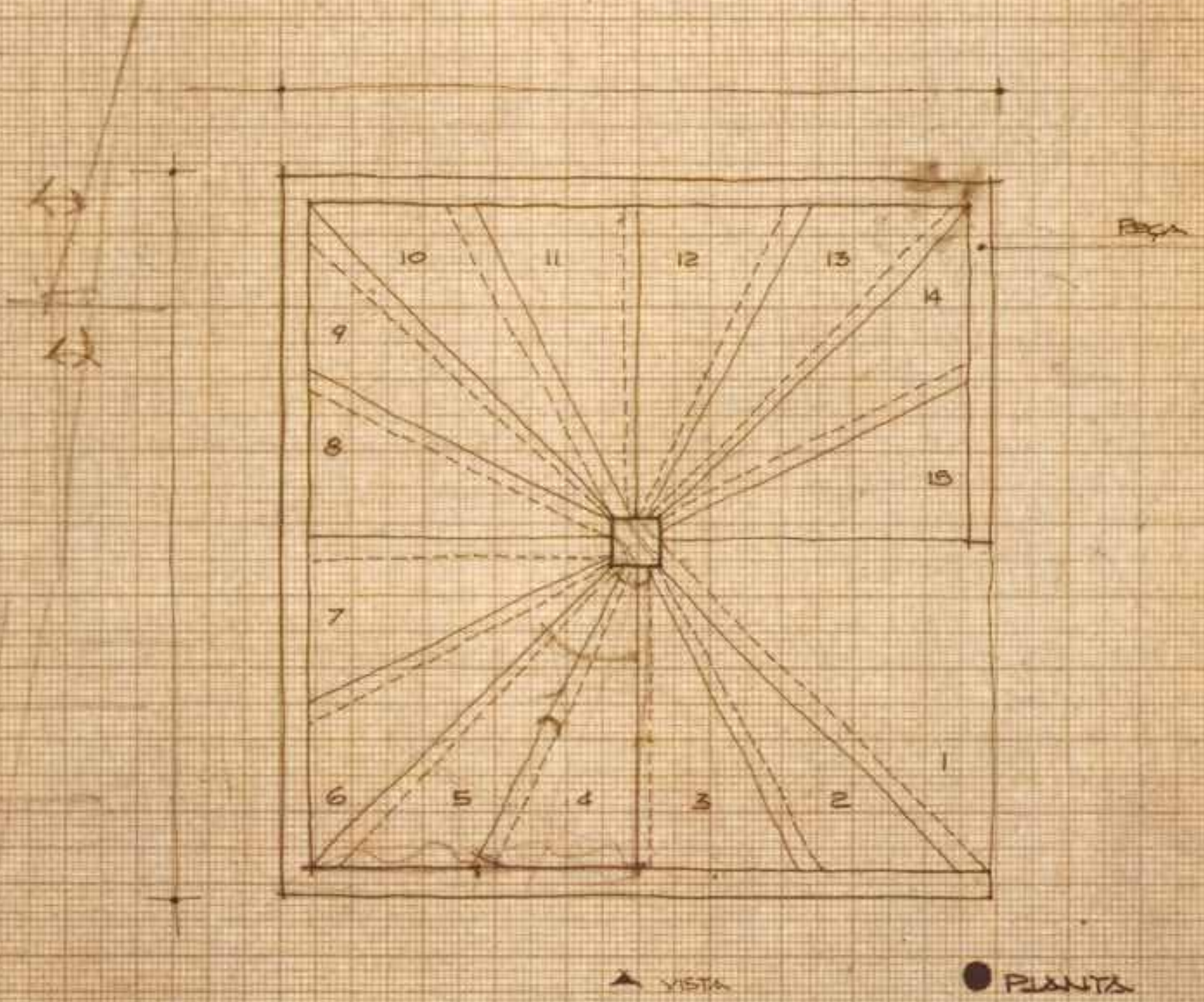

+.:-

ISTA

$\sqrt{5-3}$

Zanini e Landri

bETALHE DK ESCAtaA

tre $1 / 20$. $\quad \operatorname{seg} 79$ 
Figura 100. Nas páginas

anteriores, detalhe padrão de

escada que foi usada na casa do

Morumbi. Fonte: acervo pessoal

de Ivan do Valle.

\section{Programa da residência no Morumbi}

Interessa-nos agora entender o programa da residência. Ele é simples e podemos dizer que a área íntima é completamente dividida da social, deixando a última no primeiro patamar da residência e a primeira no último andar. Além disso, há um depósito no subsolo, aproveitando o desnível da casa, que é toda rodeada por jardins. Para melhor compreensão do programa, faremos uma análise detalhada acompanhada do desenho da planta.

Quem chega á residência logo vê uma escada à direita (f.102). Subindo a mesma escada que contorna a praça da entrada, chegamos à varanda (f.104 e f.105) que, com $6 \mathrm{~m}$ de largura por $3 \mathrm{~m}$ de profundidade, é devidamente mobiliada para servir como espaço de estar, com sofás e redes que nos permitem apreciar o jardim da frente da casa. A varanda conecta o mundo externo com o interno da residência; é um espaço de transição.

Pela varanda adentramos a área interna da casa. Toda a área social da residência fica nesse andar, a sala de TV, a de estar com uma lareira, a de jantar, um banheiro social, a cozinha, uma dispensa, a área de serviço e um quarto com banheiro privativo.

Não há paredes entre a sala de estar e de jantar, o que nos permite uma visão ampla da estrutura da casa, onde podemos notar as cantoneiras que prendem as vigas nos pilares. Um detalhe bonito, que pode ser visto na sala mas é utilizado em diversos cômodos, são as luminárias. $\mathrm{O}$ arquiteto aproveita o espaçamento dos barrotes para encaixar entre eles as luminárias de teto.

Isso nos traz à memória as casas da Joatinga, para as quais Zanine desenhou móveis fixos na estrutura do piso da residência, no sentido de pensar a construção nos mínimos detalhes, aproveitando a estrutura para solucionar equipamentos necessários ao morar.

Também existe na sala uma bela escada cujos degraus rodeiam o pilar quadrado, formando uma helicoide. Essa escada foi usada em diversos projetos de Zanine (f.106).

Outro detalhe bonito são as portas de madeira voltadas para a fachada privativa da residência, entalhadas pelos carpinteiros de Nova Viçosa. Nela podemos sentir com o tato a maciez do trabalho com a enchó, que esculpiu na porta formas côncavas e convexas.

Passando através dessa porta, chegamos ao jardim dos fundos, que forma um retângulo com aproximadamente $14 \mathrm{~m}$ de largura por $5 \mathrm{~m}$ de profundidade, espaço suficiente para a existência de duas árvores e uma mesa para se estar num dia ensolarado (f.112).

O jardim dos fundos cria uma dupla frontalidade, a que se produz no plano vertical da entrada e a que corresponde ao âmbito privado. As salas de estar e de jantar são a passagem de uma fachada à outra. No lado da fachada privativa podemos observar o mesmo sistema construtivo que contemplamos na fachada de acesso, conferindo, assim, continuidade nas elevações. Também podemos observar, no segundo andar, a repetição nítida dos módulos das janelas, com $1 \mathrm{~m}$ de largura cada. Essas janelas voltamse para os 3 quartos. 


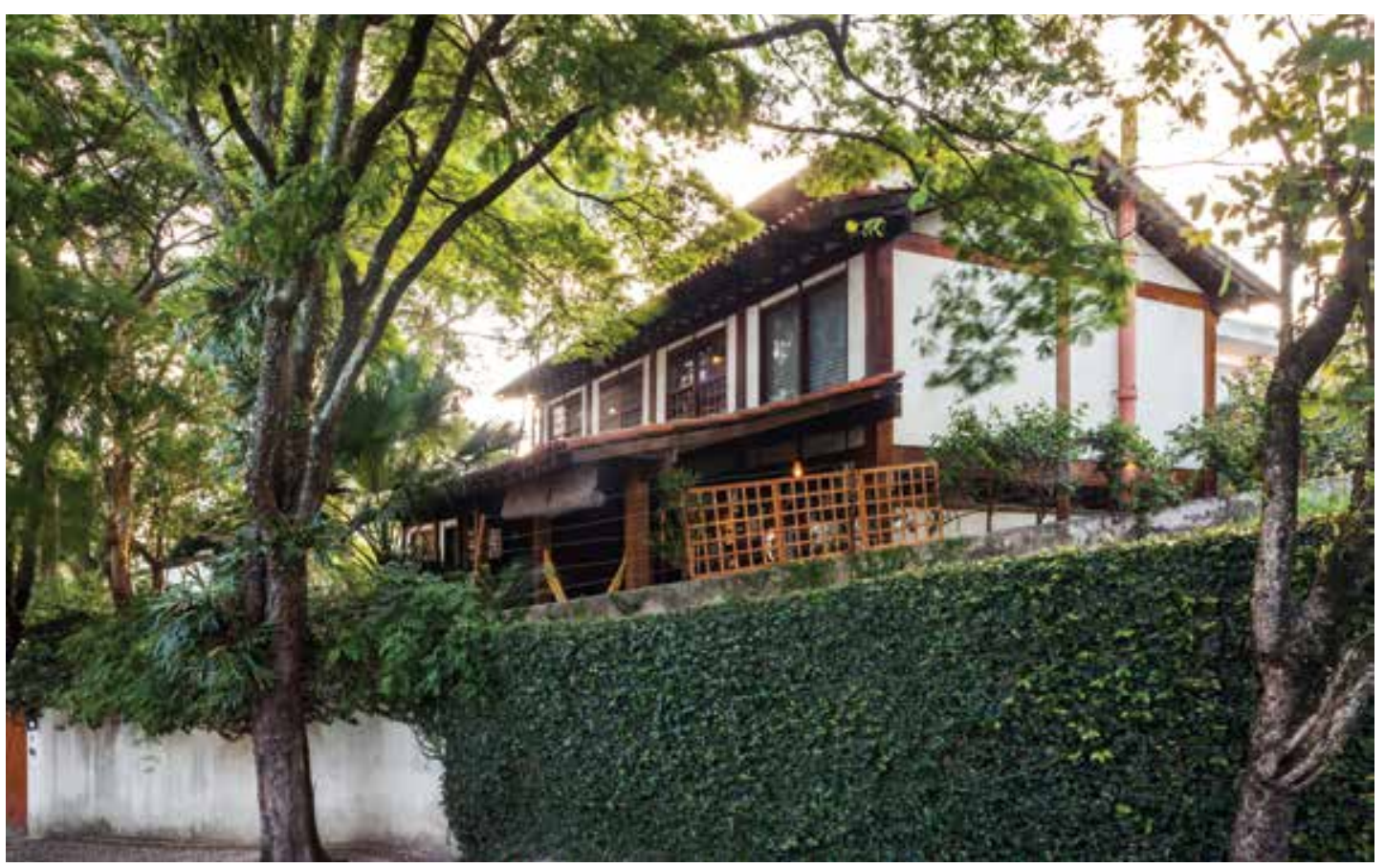

Figura 101. Vista lateral da residência. Fonte: acervo pessoal de Amanda Carvalho, fotografia de Rafaela Netto.

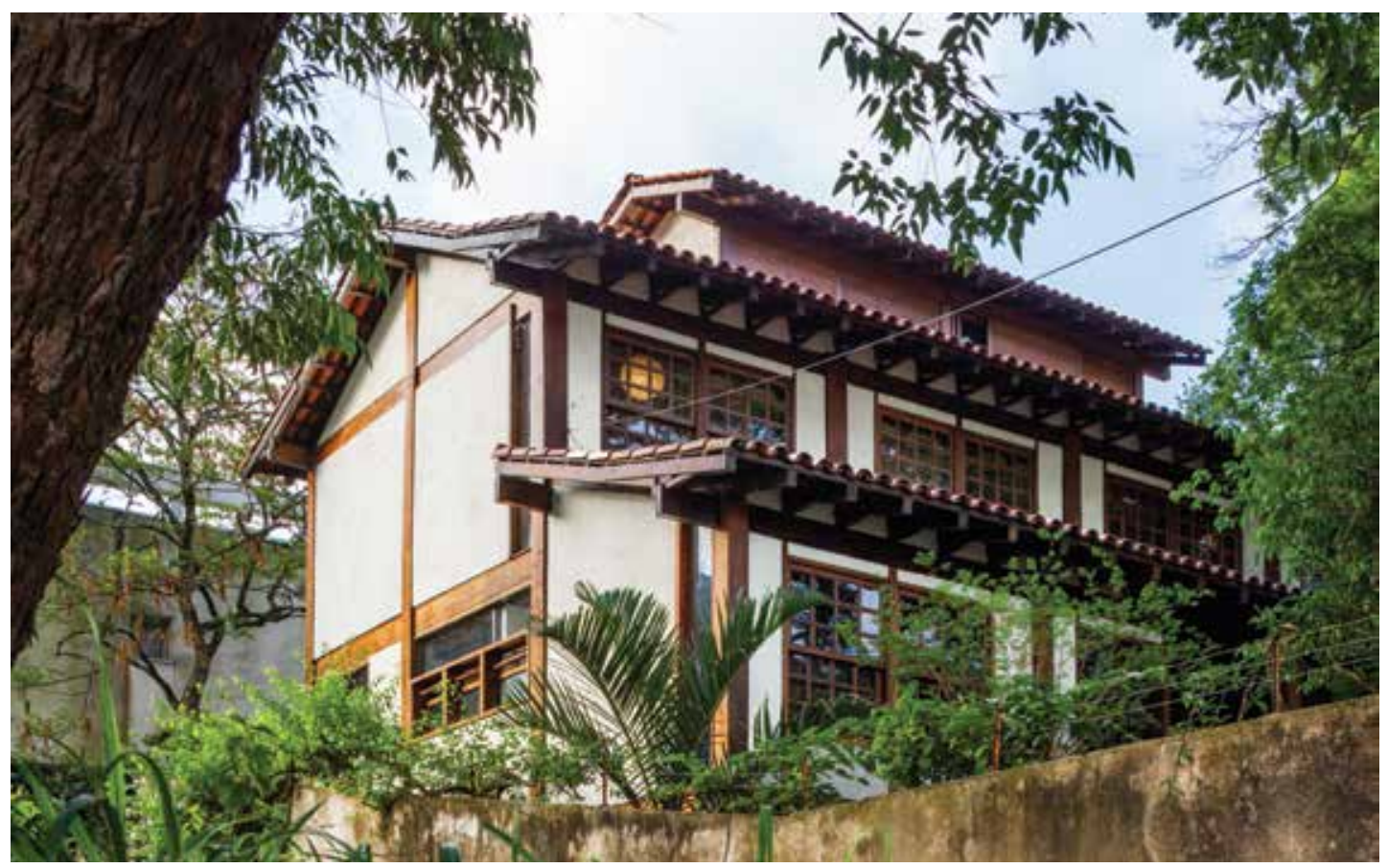

Fig. 102. Vista lateral da residência. Fonte: acervo pessoal de Amanda Carvalho, fotografia de Rafaela Netto. 
Figura 103. Entrada da casa

do Morumbi. Fonte: acervo

pessoal de Amanda Carvalho,

fotografia de Rafaela Netto.

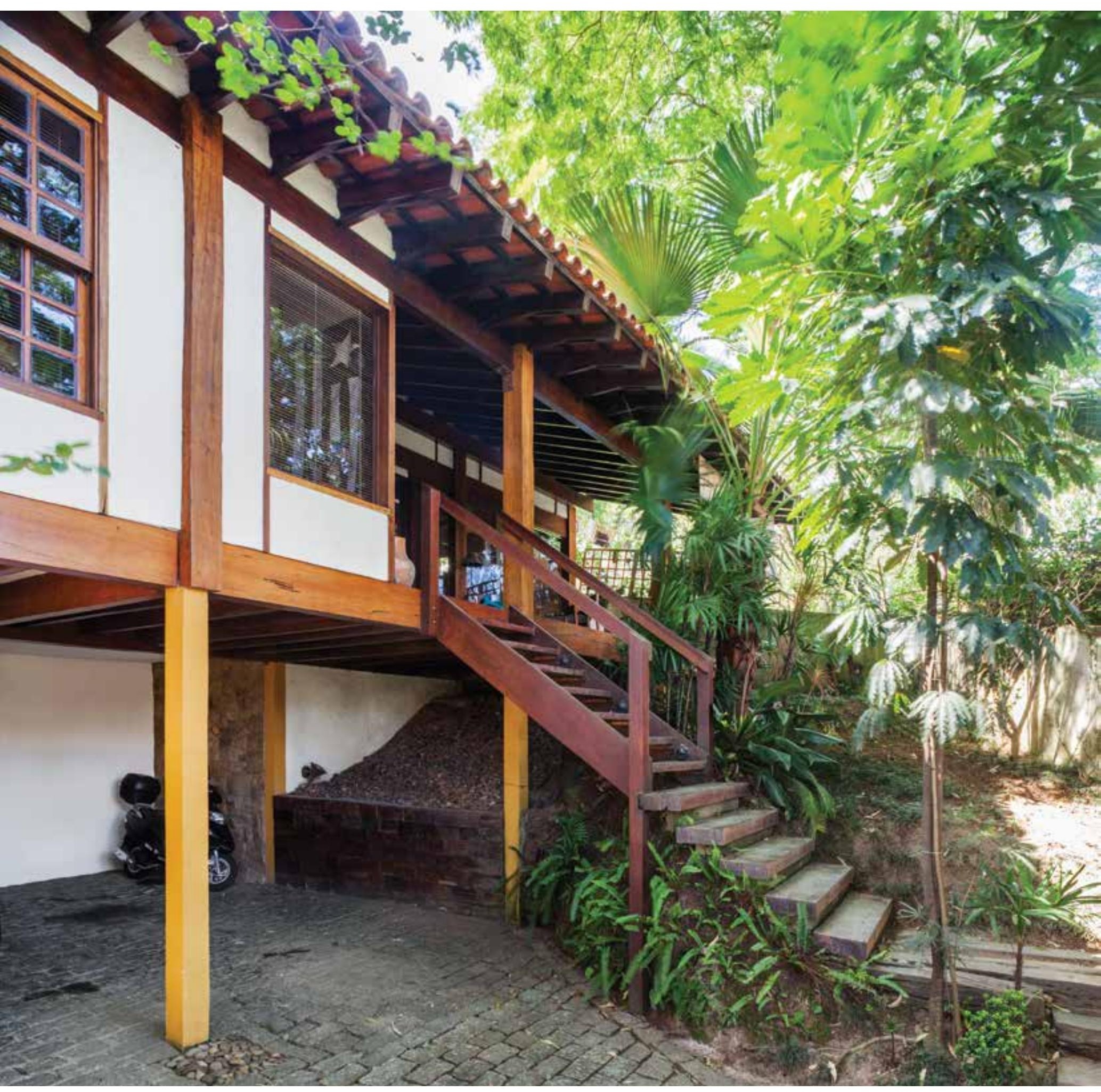


Subindo as escadas (f.103), chegamos à área íntima da residência. Vemos um amplo corredor, que percorre a fachada pública da casa e que tem função dupla: serve como escritório e como corredor, conduzindo para os três quartos que ficam nesse andar, sendo um suíte e um banheiro. O desenho da suíte é interessante por possuir um armário que divide uma ante sala e um closet, da área de dormir (f..115).

Também há, nesse espaço, uma escada estilo Santos Dumont. Ela foi construída posteriormente, quando Hélio Olga vendeu a casa para o casal Fernanda e Joaquim, que precisavam de um quarto a mais para seus filhos. Sendo assim, essa escada nos leva para o último andar da casa, um pequeno quarto.

Em 1991, Hélio vendeu sua casa para o casal Joaquim e Fernanda, atuais donos da residência. Foi quando pediram o projeto de ampliação de um quarto para Hélio Olga, que nos explicou:

Depois a gente fez um andar a mais, num pedacinho, porque tinha um problema na caixa d'água e porque eles têm três filhos e só tinham três quartos. Enfim, hoje os filhos deles são adultos, mas na época eles eram pequenos, enfim, a gente acabou fazendo um puxadinho lá em cima e ficou bonito, não descaracterizou muito, para melhorar a altura da caixa d'água. (OLGA, depoimentto de 02/02/2017)

Atualmente, a casa tem quase 40 anos, está em ótimo estado de conservação. Nos 9 primeiros anos em que esteve sob os cuidados do engenheiro Hélio Olga, a madeira não tinha nenhum acabamento. $\mathrm{O}$ segundo proprietário envernizou a casa, procedimento que não era aconselhado por Zanine e também não o é por nenhum dos arquitetos entrevistados que trabalharam com Zanine.

Hélio Olga, explicando sobre a questão da montagem e desmontagem da casa em Nova Viçosa, para uma posterior montagem no local definitivo, diz que esse processo só acontecia porque Zanine trabalhava com madeira bruta e com uma mão de obra muito barata, o que possibilitava a montagem de uma mesma casa duas vezes. Para usar a mão de obra do local, Zanine teve que adaptar a forma de produção das casas para trabalhadores que não sabiam ler, mas que sabiam contar e trabalhar com madeira. Por isso ele criou a malha no piso, pois assim podia dizer: quero uma casa de $5 \times 5 \mathrm{~m}$. Os canoeiros contavam 5 pontos na malha, colocavam a viga em cima e cortavam ela. Para isso, eles precisavam montar a casa para cortar os pedaços de madeira no tamanho correto.

Só que, o que acontece quando você trabalha com madeira bruta, você é obrigado a fažer isso daqui, necessariamente. Você monta, desmonta e monta. Isso tem um custo. A gente começou a aparelhar a madeira. E fazer uma vez só. Sem montar, desmontar e montar. Mas a mão de obra dele era uma mão de obra que não sabia ler. Ele teve que se adaptar ao local. E aqui em São Paulo a mão de obra não era tão barata como a de lá. Então, se eu tivesse que fazer o sistema do Zanine aqui, montar, desmontar, ai montar de novo, eu teria que pagar uma miséria para o montador, o que não era uma ideia. (OLGA, depoimento de 02/02/2017) 


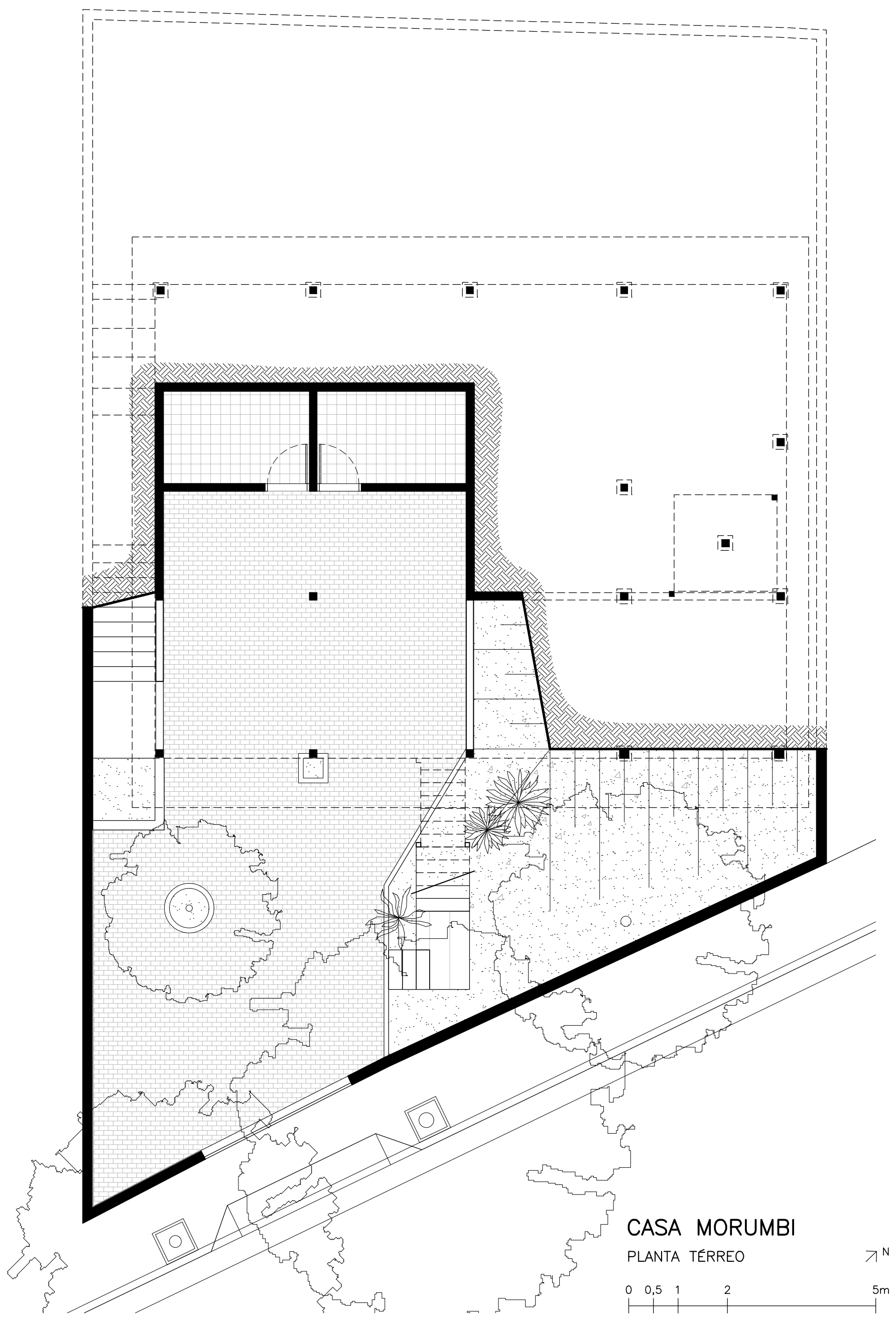




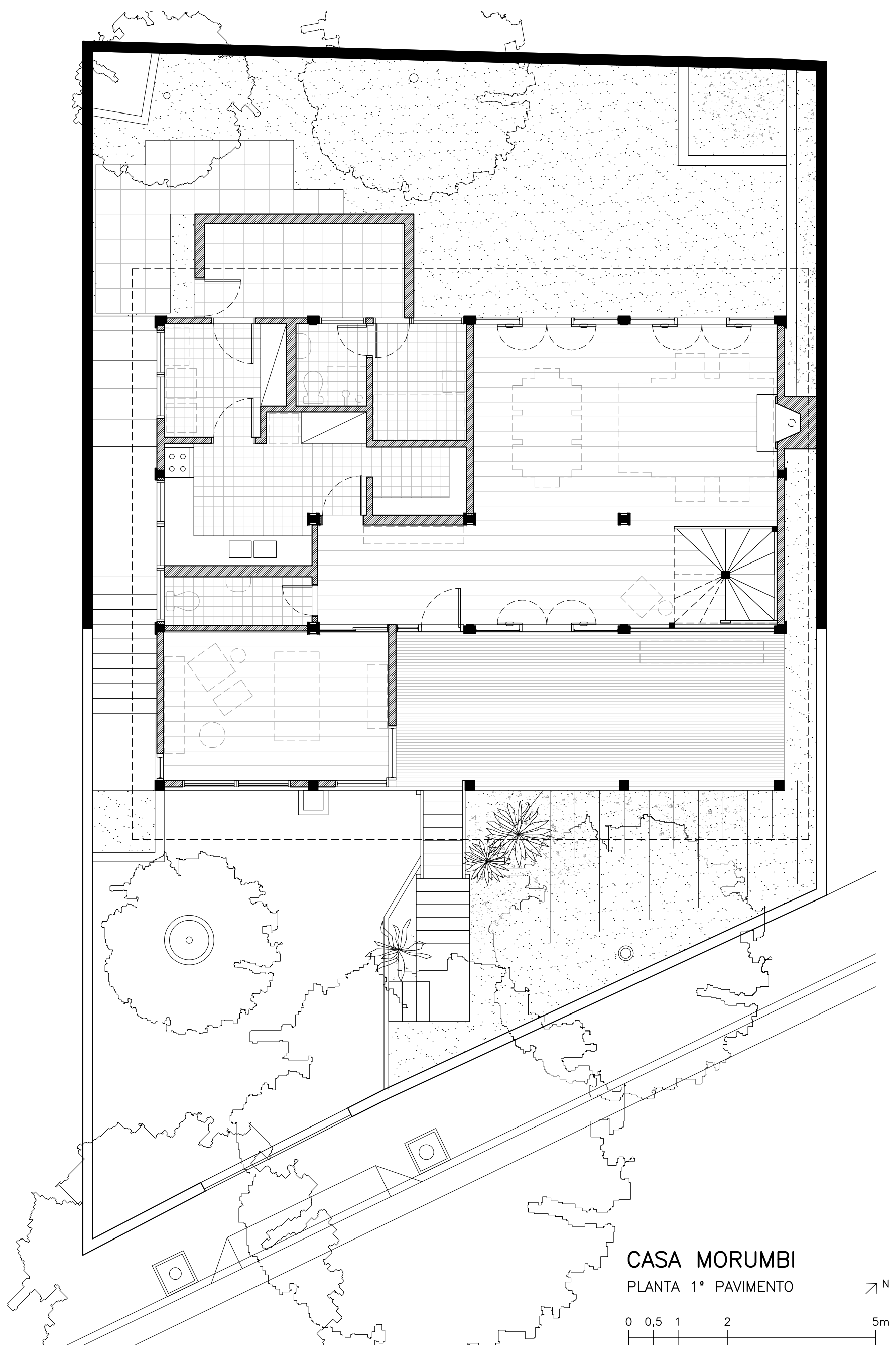




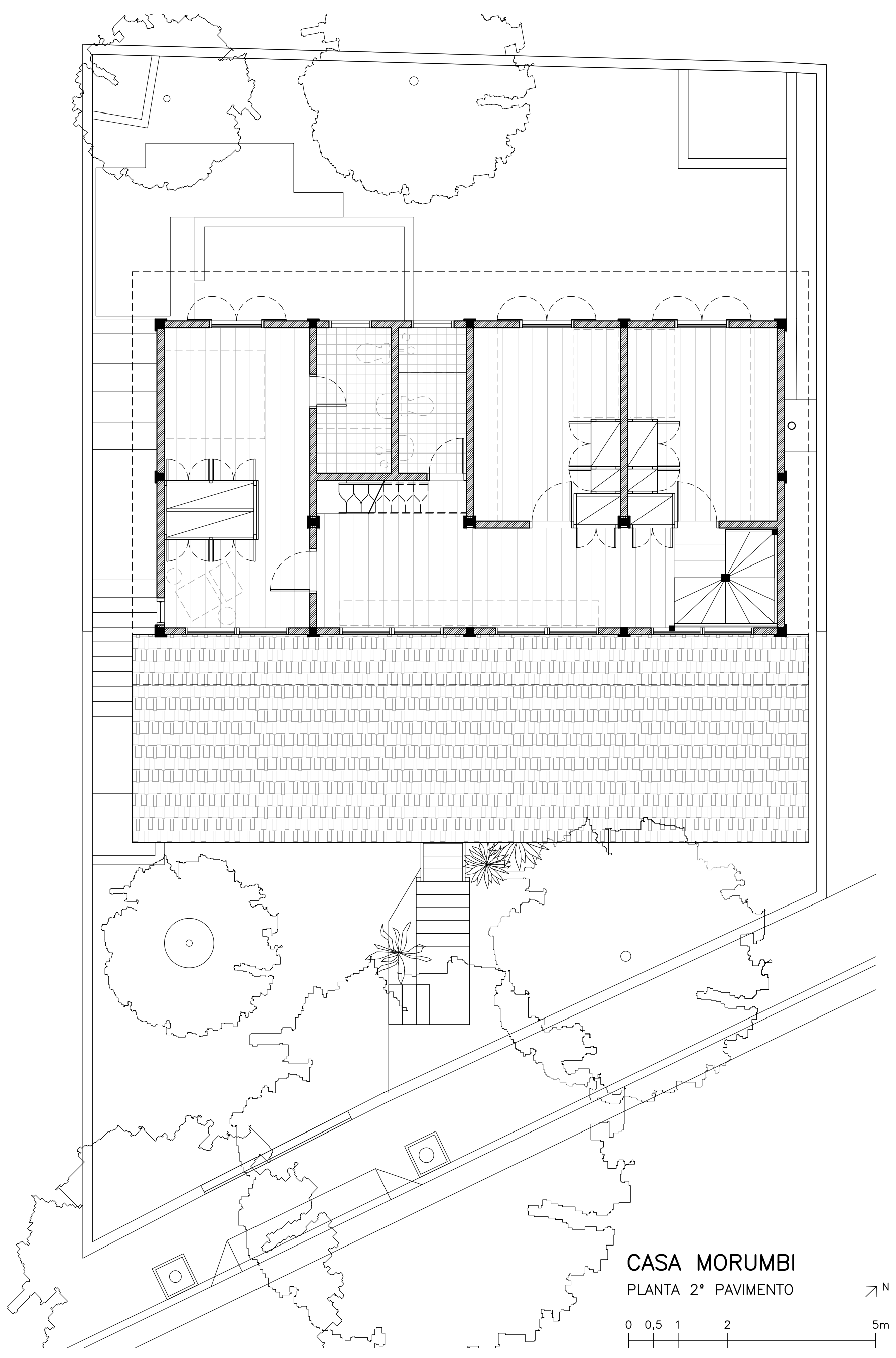




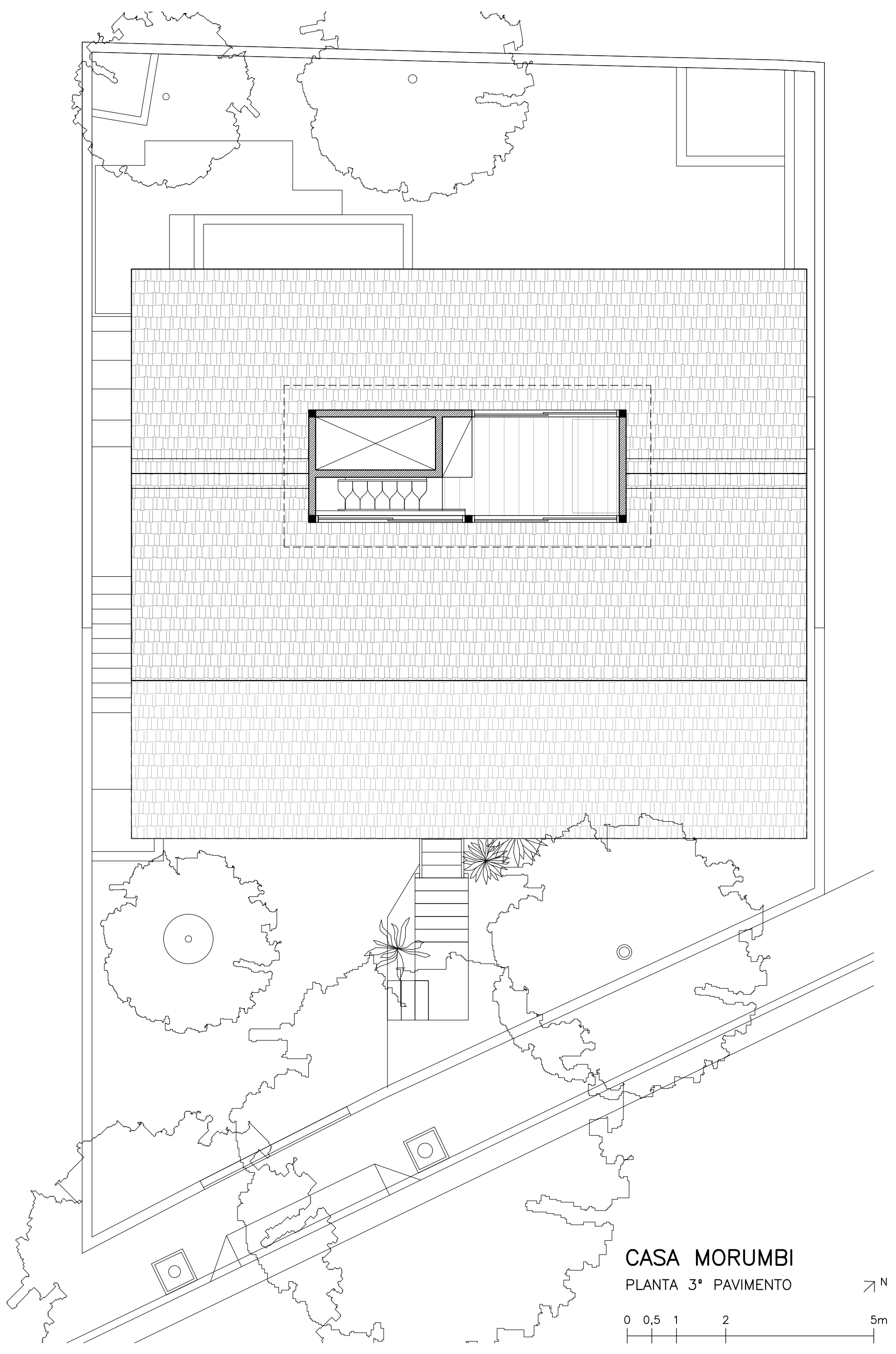




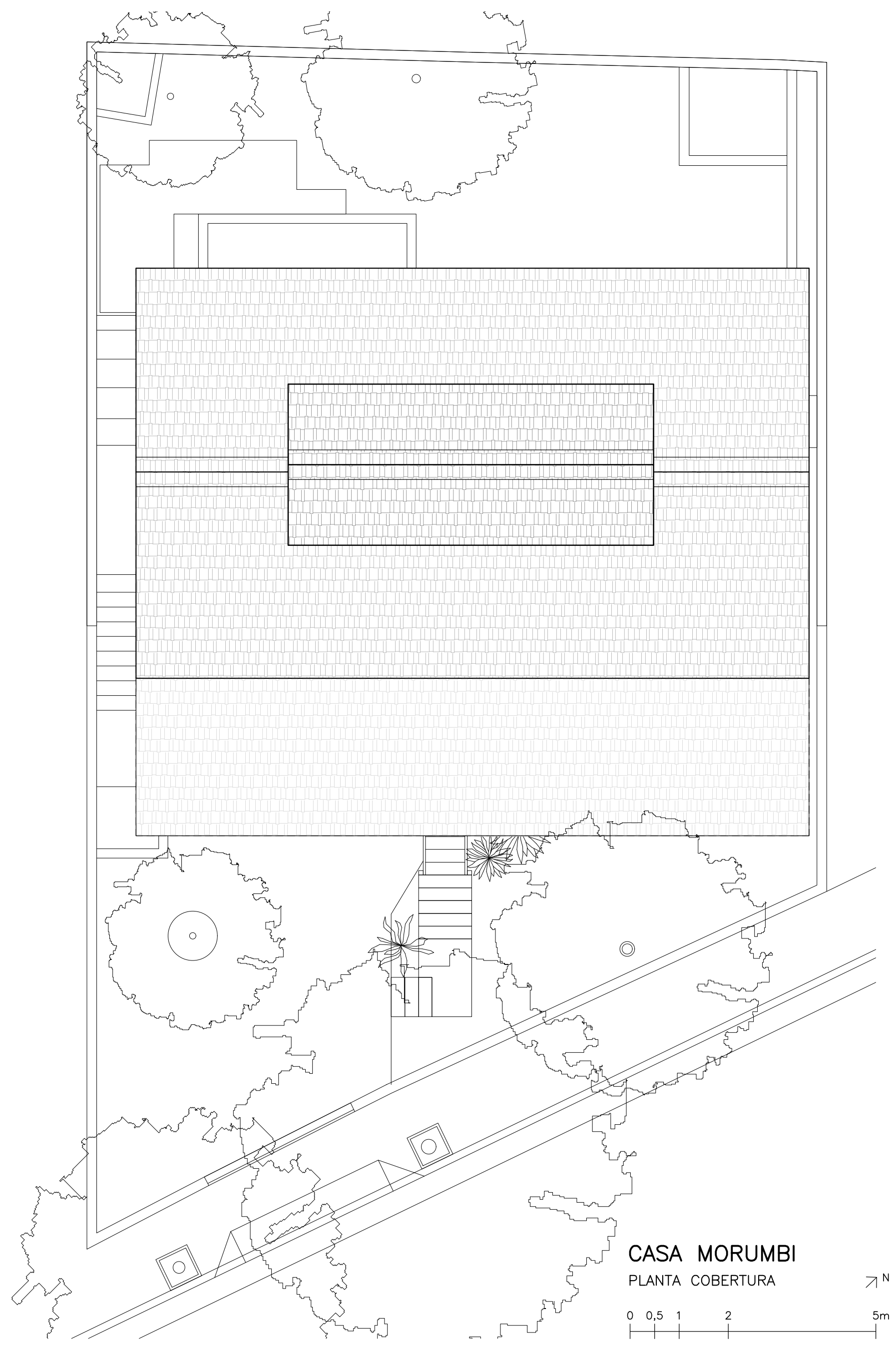




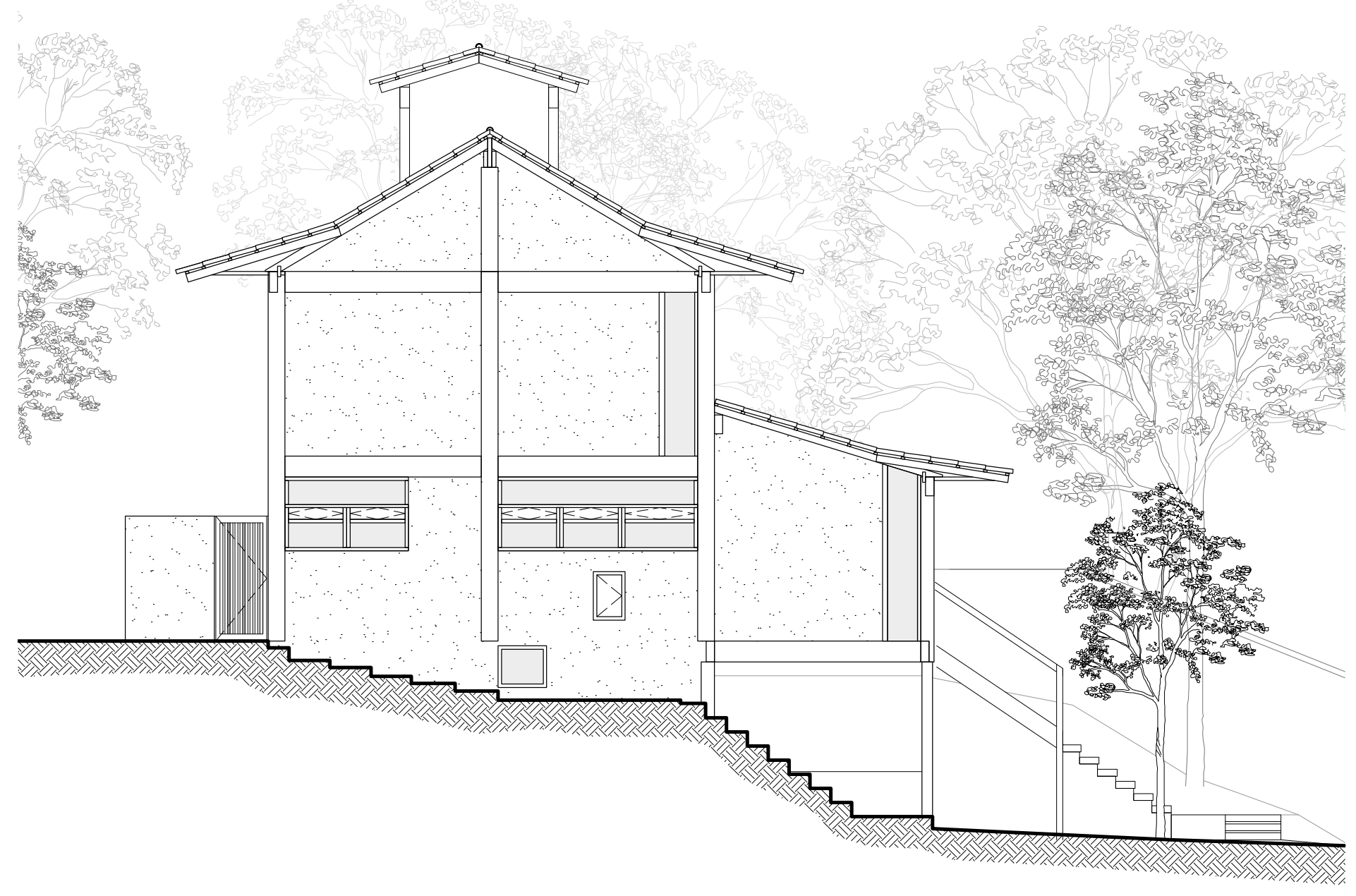

CASA MORUMBI

FACHADA SUDOESTE 


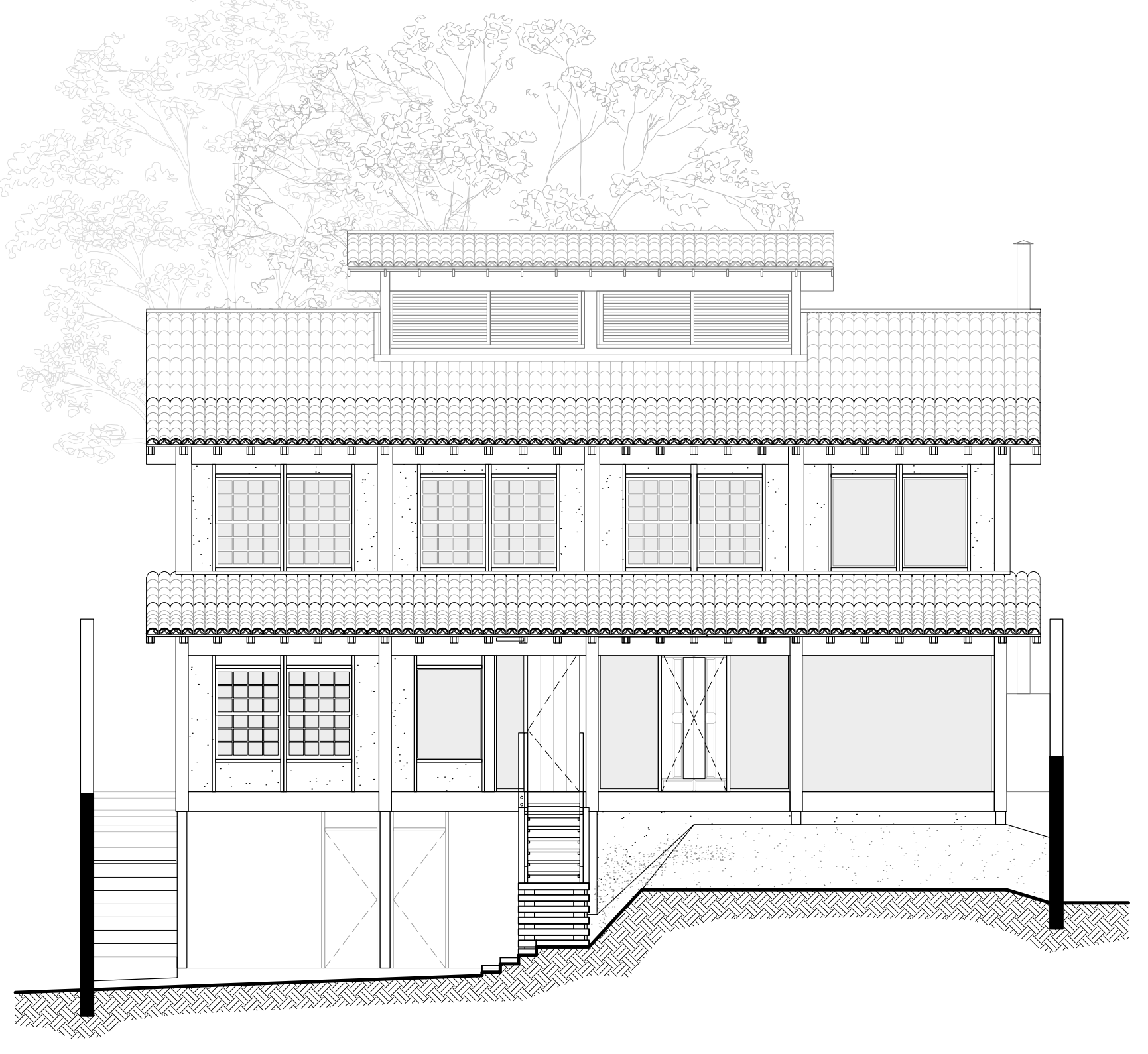

CASA MORUMBI

FACHADA NOROESTE 


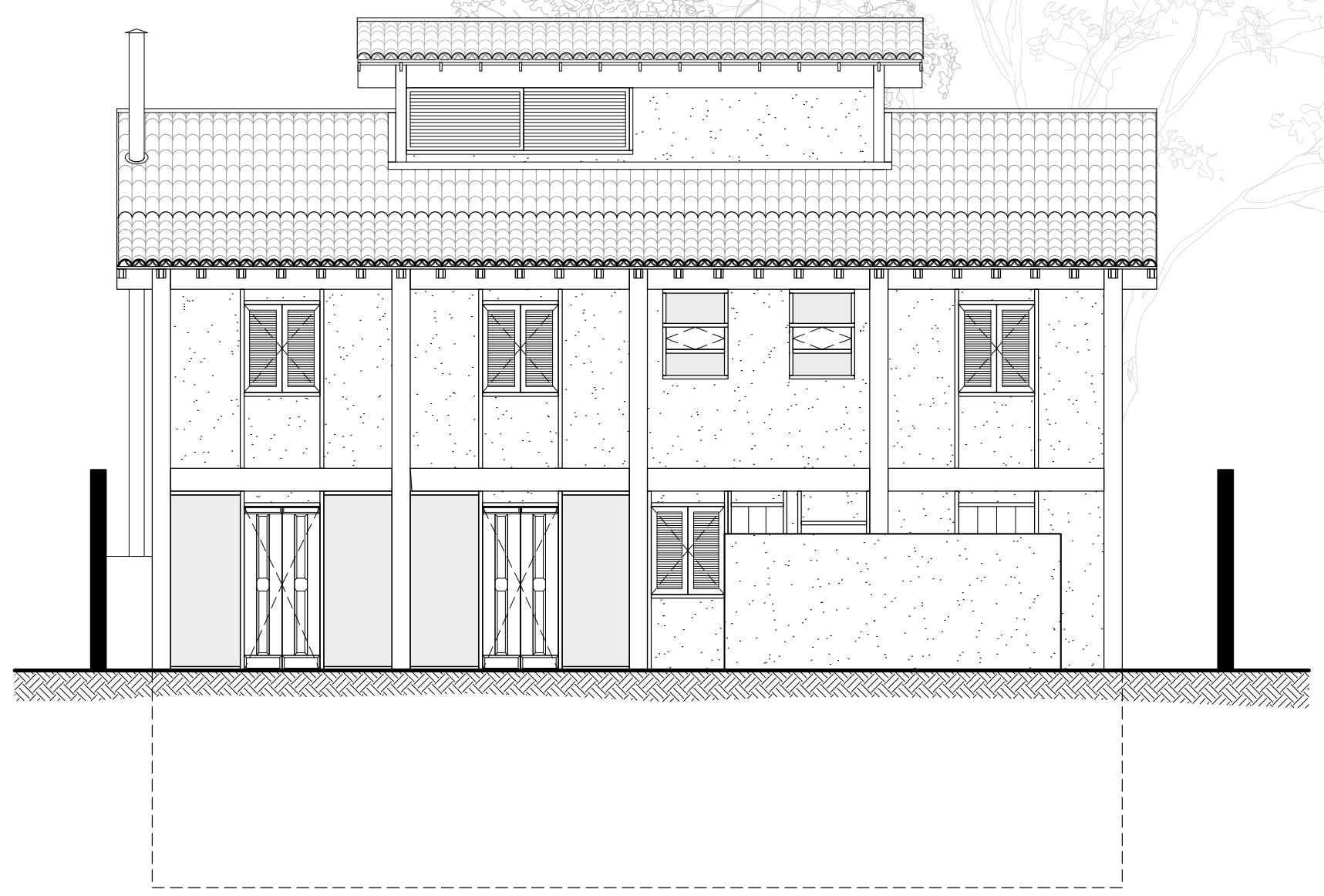

CASA MORUMBI

FACHADA NOROESTE 


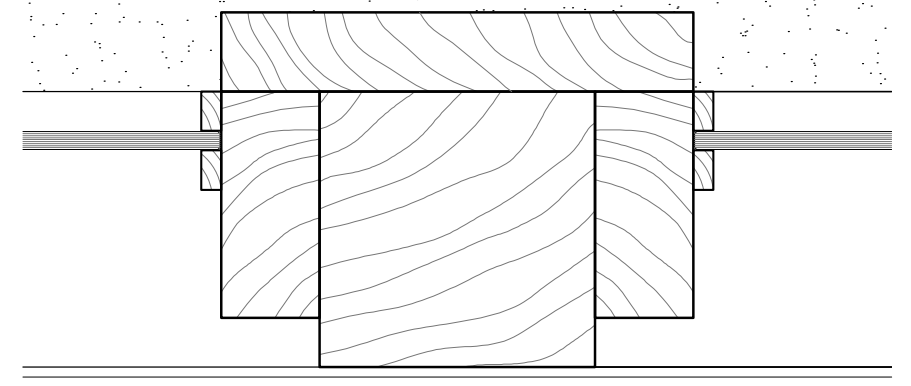

PILAR FACHADA

CENTRAL

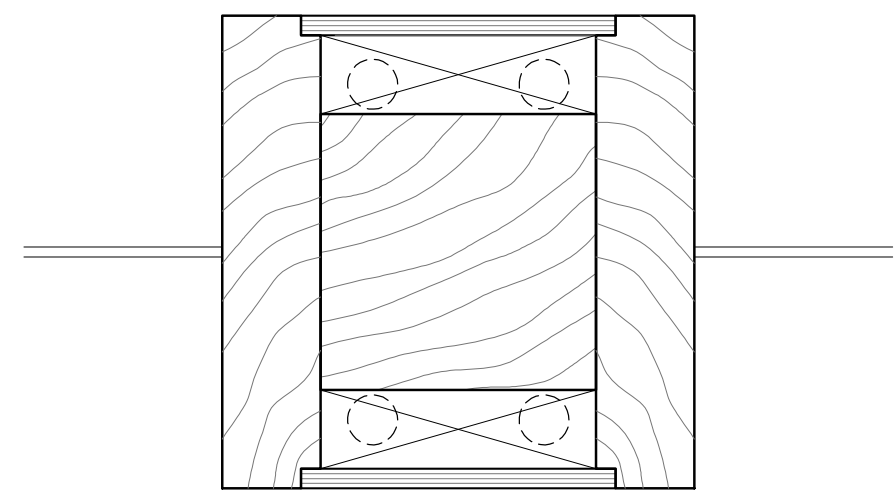

PILAR INTERNO

CENTRAL

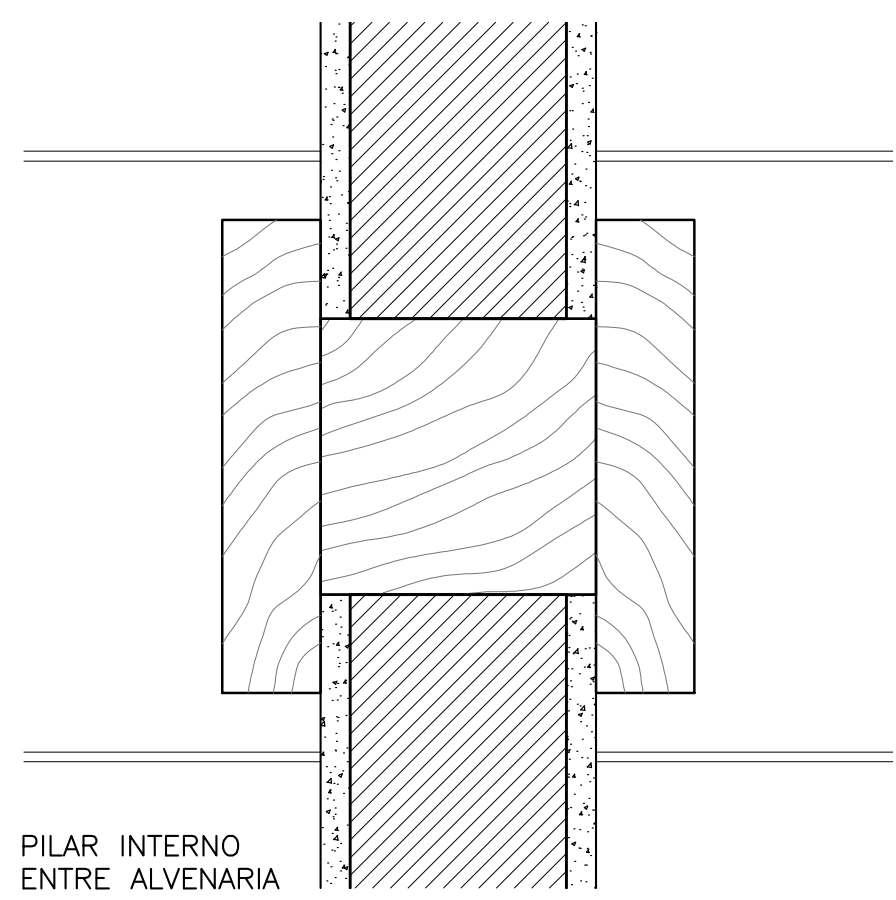

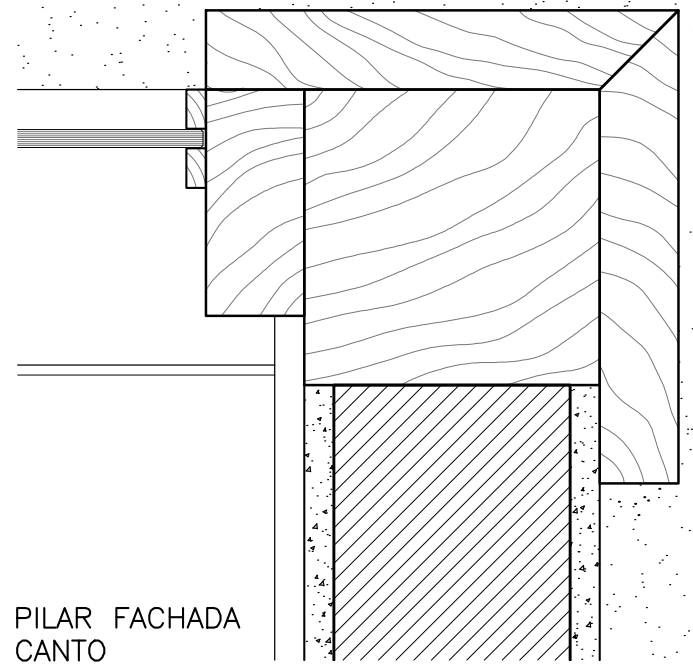

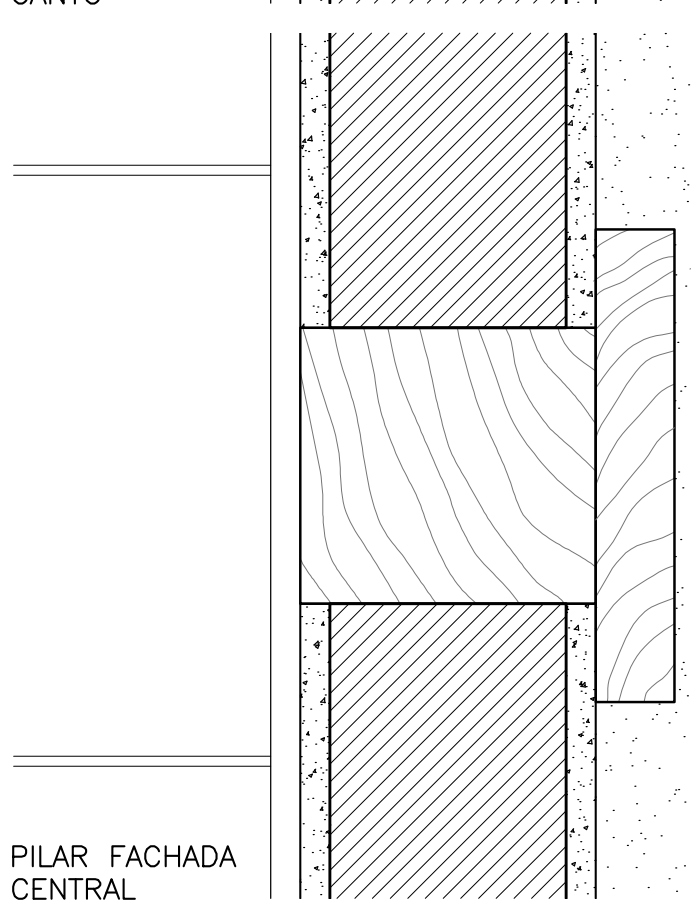

CENTRAL
CASA MORUMBI

DETALHES - TIPOS DE PILARES

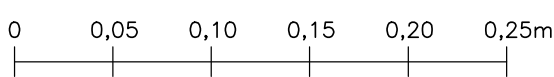


Nas páginas anteriores,

desenhos técninos da casa

do Morumbi. Fonte: Rafael

Murolo e Amanda Carvalho.

O interesse da análise de um caso como esse é mostrar o que Zanine entende como arquitetura. Assim, podemos ver que a forma dessa casa responde diretamente ao que demandavam a técnica construtiva, o lugar da sua produção, e o programa da residência somados às referencias usadas por Zanine, trazidas de sua infância em Belmonte, das suas viagens por continentes com forte tradição construtiva em madeira, como África e Ásia, assim como das suas viagens pelo interior do país, de seu trabalho para o SPHAN e de seu trabalho em conjunto com os arquitetos modernos, quando fez as maquetes dos mais importantes edifícios da época.

Essas referências são recuperadas e usadas de forma a abrigar a natureza humana com suas necessidades, mas sem limitar o uso das técnicas às formas vernaculares. Pelo contrário, nas casas de Zanine convivem técnicas construtivas autóctones com grandes painéis de vidro. Elas são caleidoscópios em que diversos momentos da história da construção se unem, criando algo diferente do existente. Mesmo usando princípios modernos, como enormes painéis de vidro e a casa elevada sobre pilares que pousam sobre o terreno, sua visão do todo era completamente diversa do que se fazia até então, abrindo caminhos que depois foram usados por outros arquitetos.

Sendo assim, as casas feitas em Nova Viçosa refletem todo o conhecimento adquirido pelo arquiteto; são o espelho da sua vida e da sua forma de ser. Curioso e inquieto, Zanine selecionava dentre a arquitetura existente sensações e técnicas que lhe interessavam. O resultado alcançado é completamente diferente do que já existiu, é uma arquitetura feita a partir da vivência, levando-nos à arquitetura como sensação.

E percorrer essa casa construída por Hélio Olga é uma experiência que nos faz refletir sobre a história da arquitetura, sobre o primeiro abrigo, resultado do acúmulo de imagens e referências que estão guardados na nossa memória. 
Figuras 104 e 105. Varanda

da casa. Fonte: acervo pessoal

de Amanda Carvalho,

fotografia de Rafaela Netto.
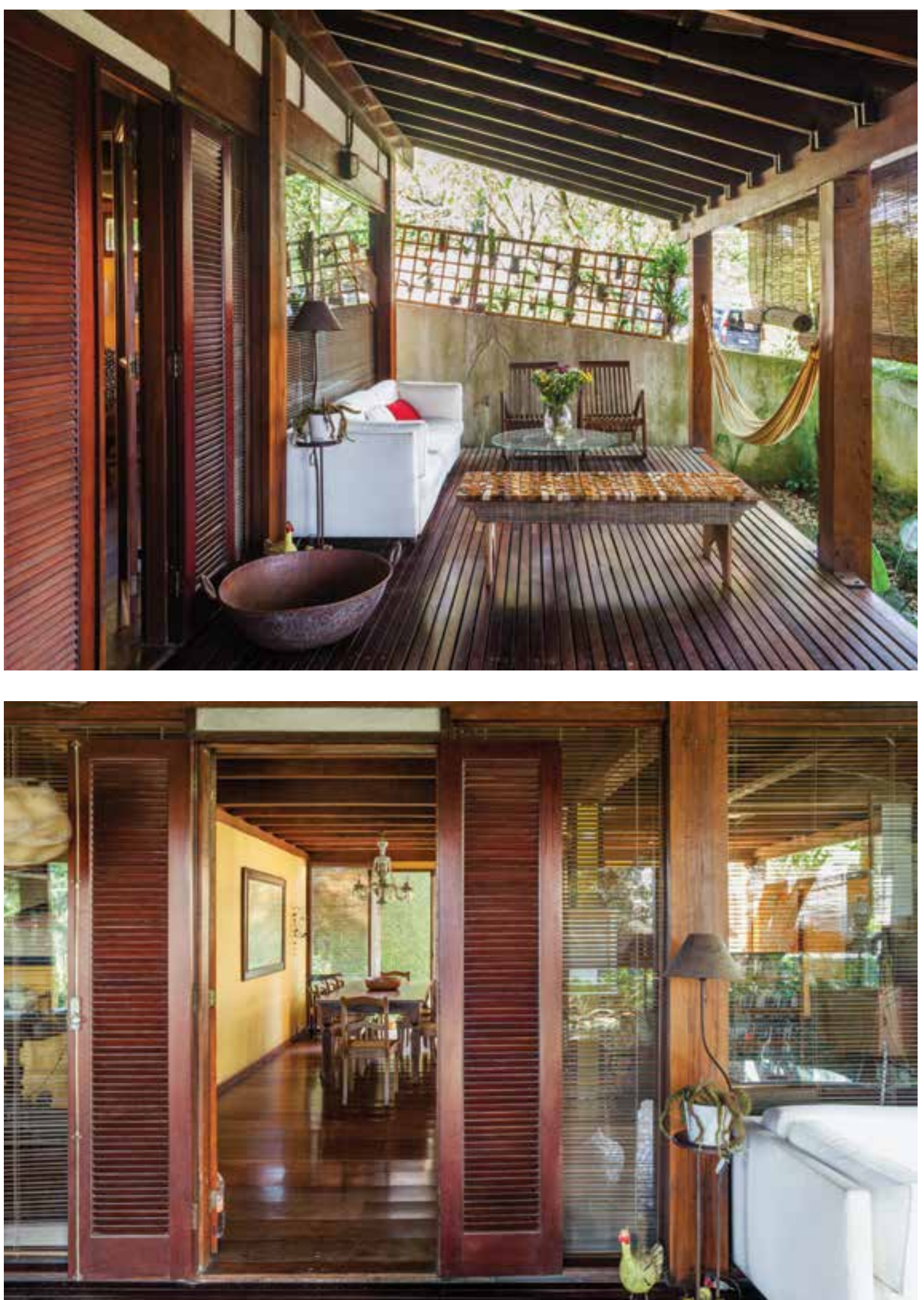
Figura 106. Escada que

conduz ao primeiro andar.

Fonte: acervo pessoal de

Amanda Carvalho, fotografia

de Rafaela Netto.

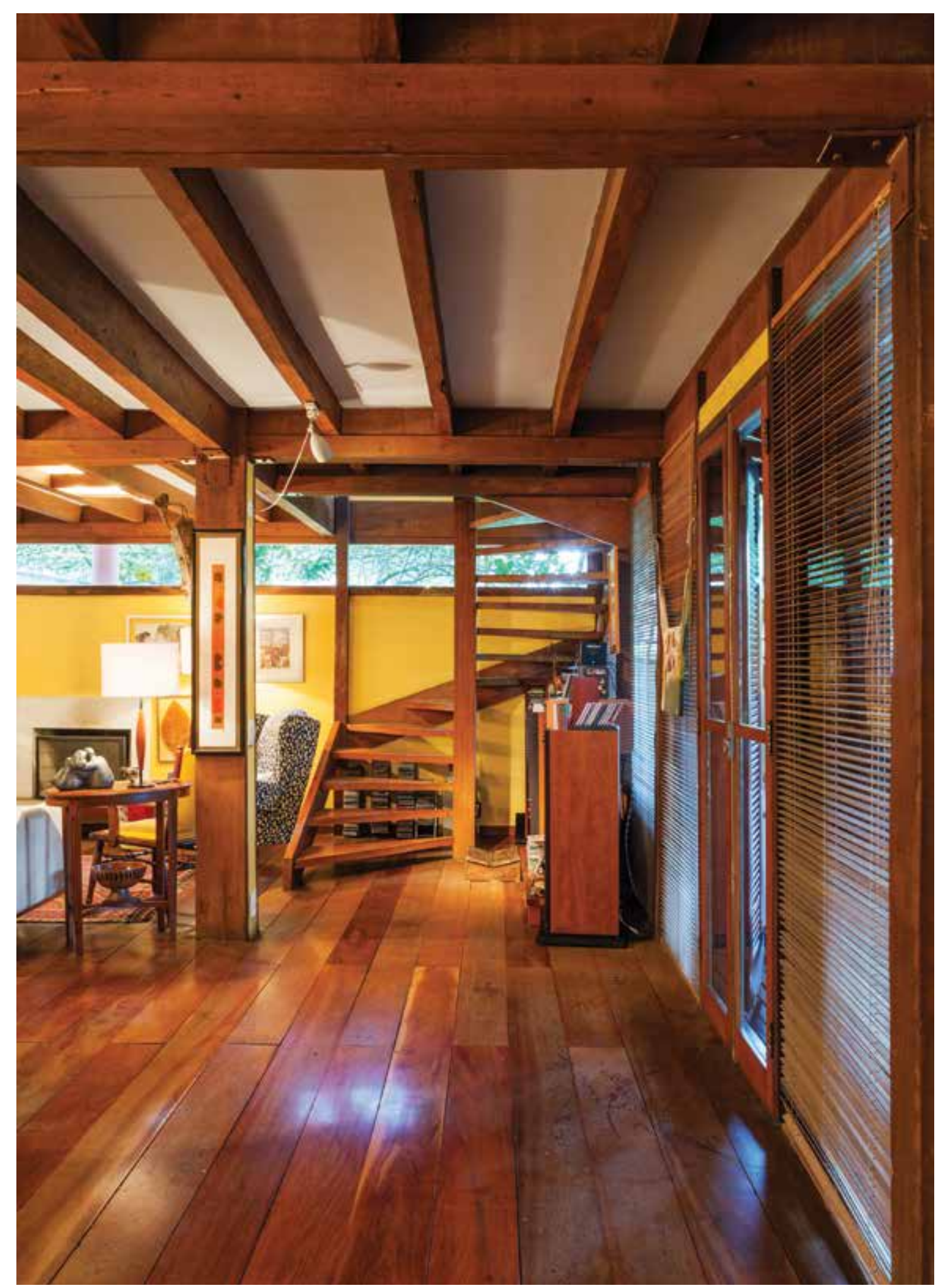


Figuras 107 e 108. Fonte:

acervo pessoal de Amanda

Carvalho, fotografia de

Rafaela Netto.
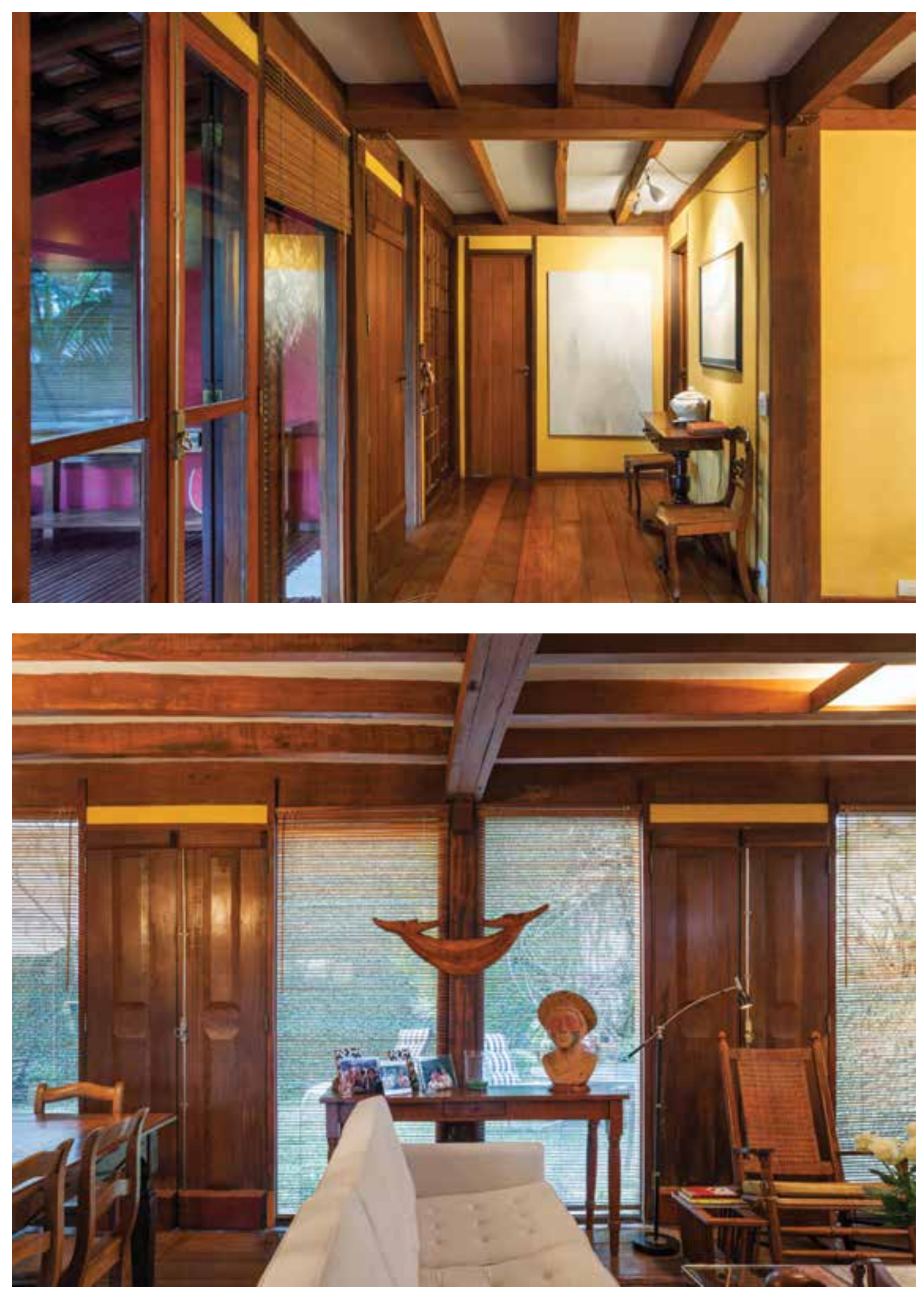
Figura 109. Fachada vista

internamente, com painél de

vidro. Fonte: acervo pessoal de

Amanda Carvalho, fotografia

de Rafaela Netto.

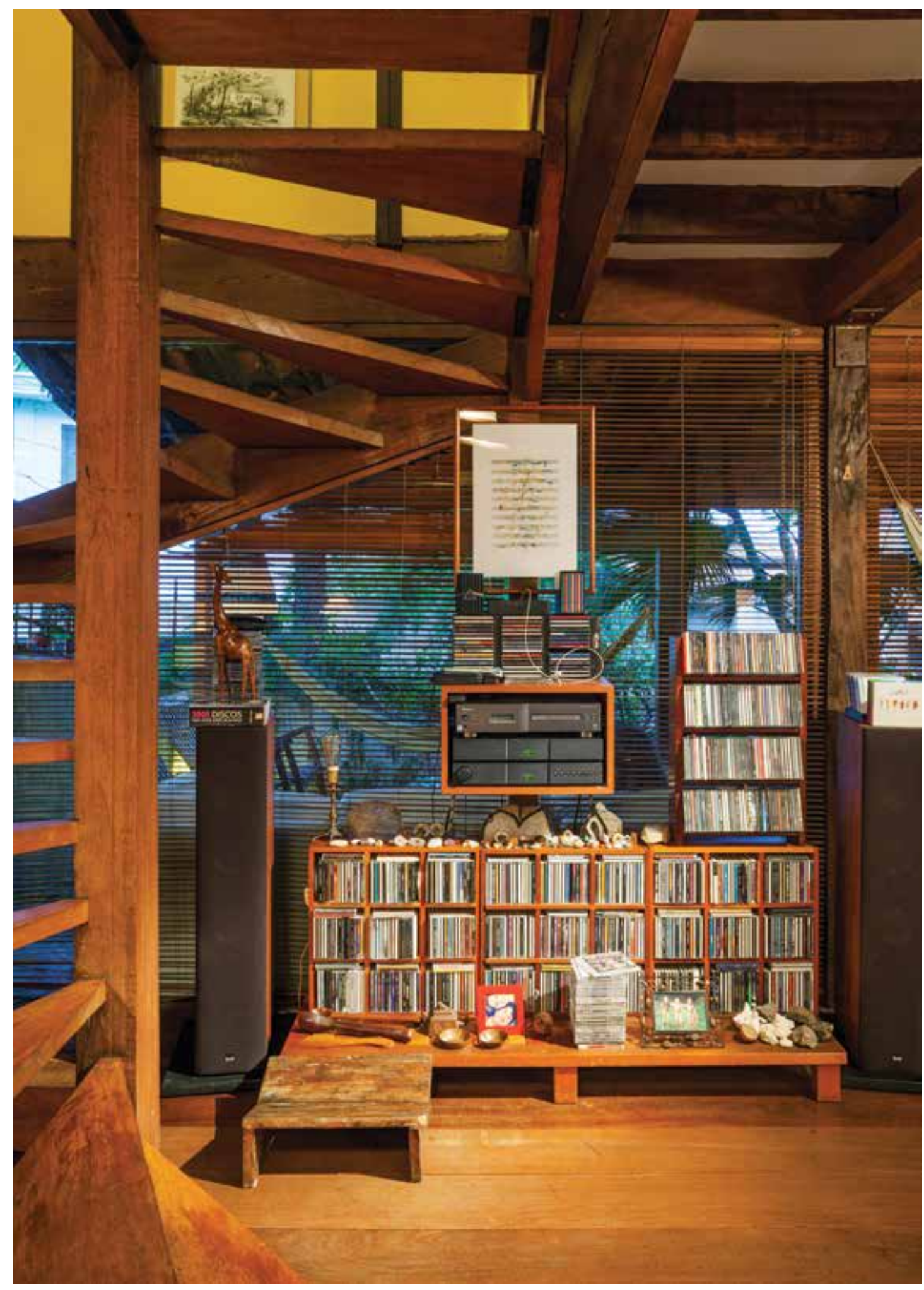


Fig. 110 e 111. Sala da

residência. Fonte: acervo

pessoal de Amanda Carvalho,

fotografia de Rafaela Netto.
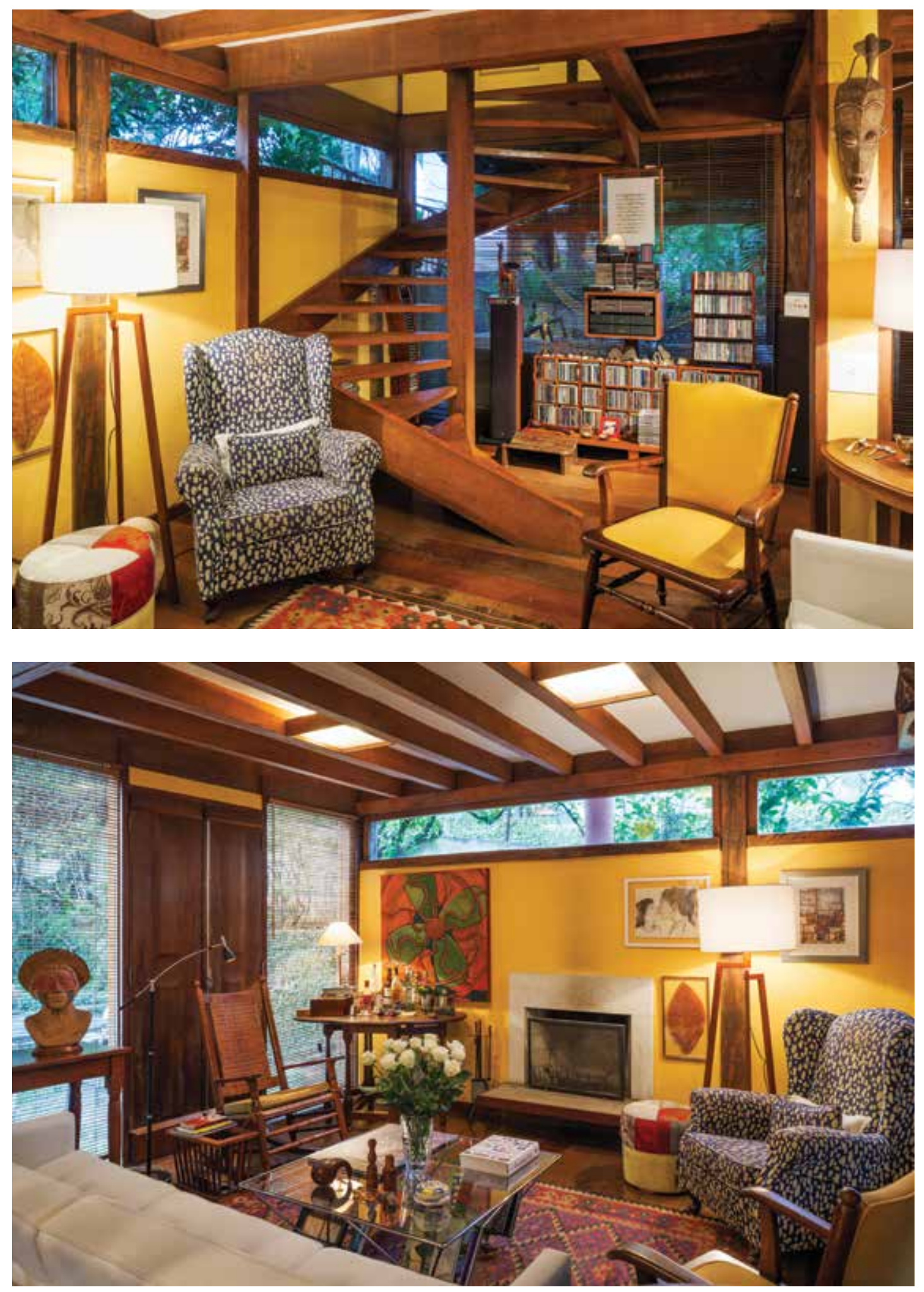
Fig. 112. Fachada interna.

Fonte: acervo pessoal de

Amanda Carvalho, fotografia

de Rafaela Netto.

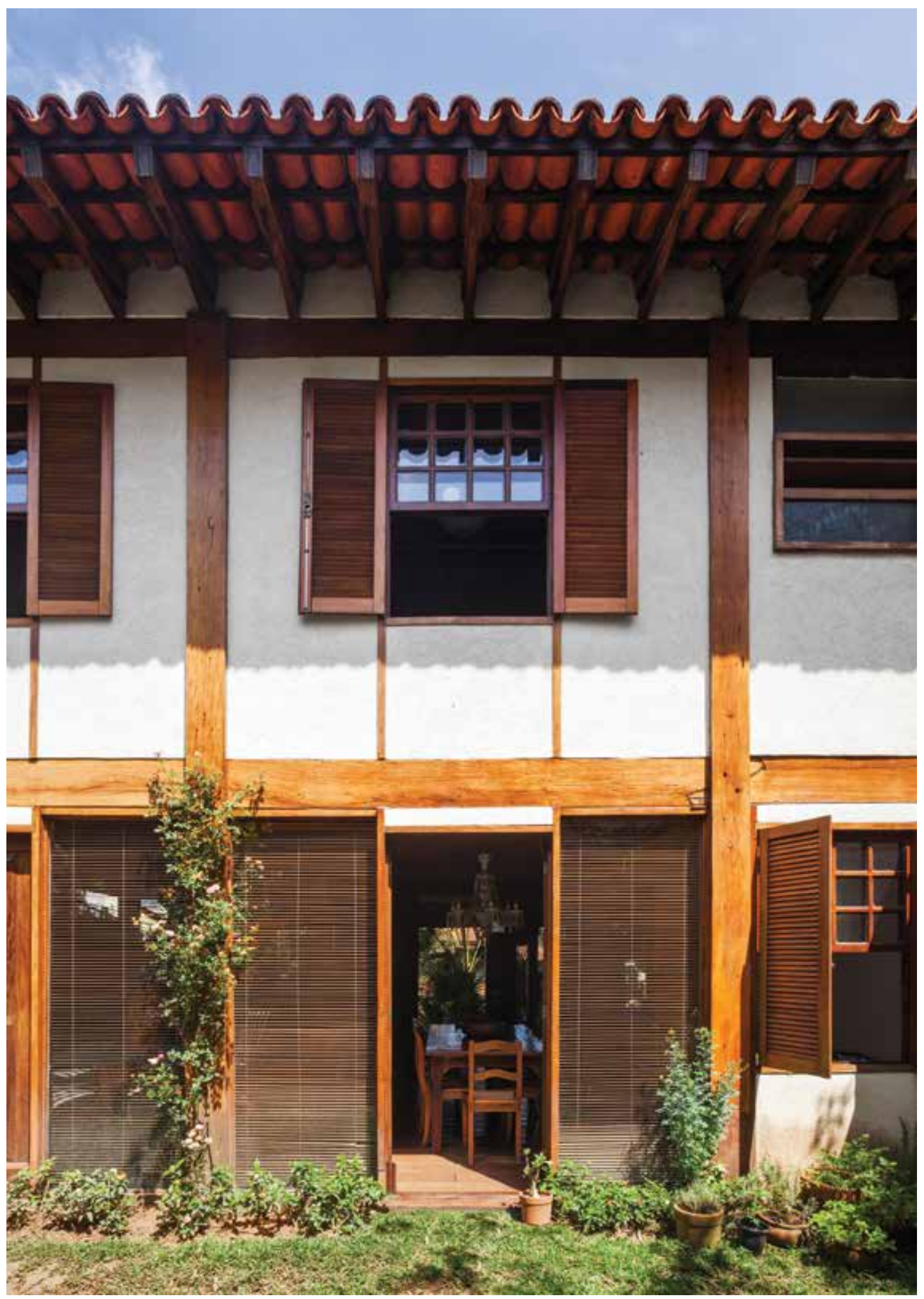


Figuras 113 e 114. Cozinha

e banheiro dos filhos. Fonte:

acervo pessoal de Amanda

Carvalho, fotografia de

Rafaela Netto.
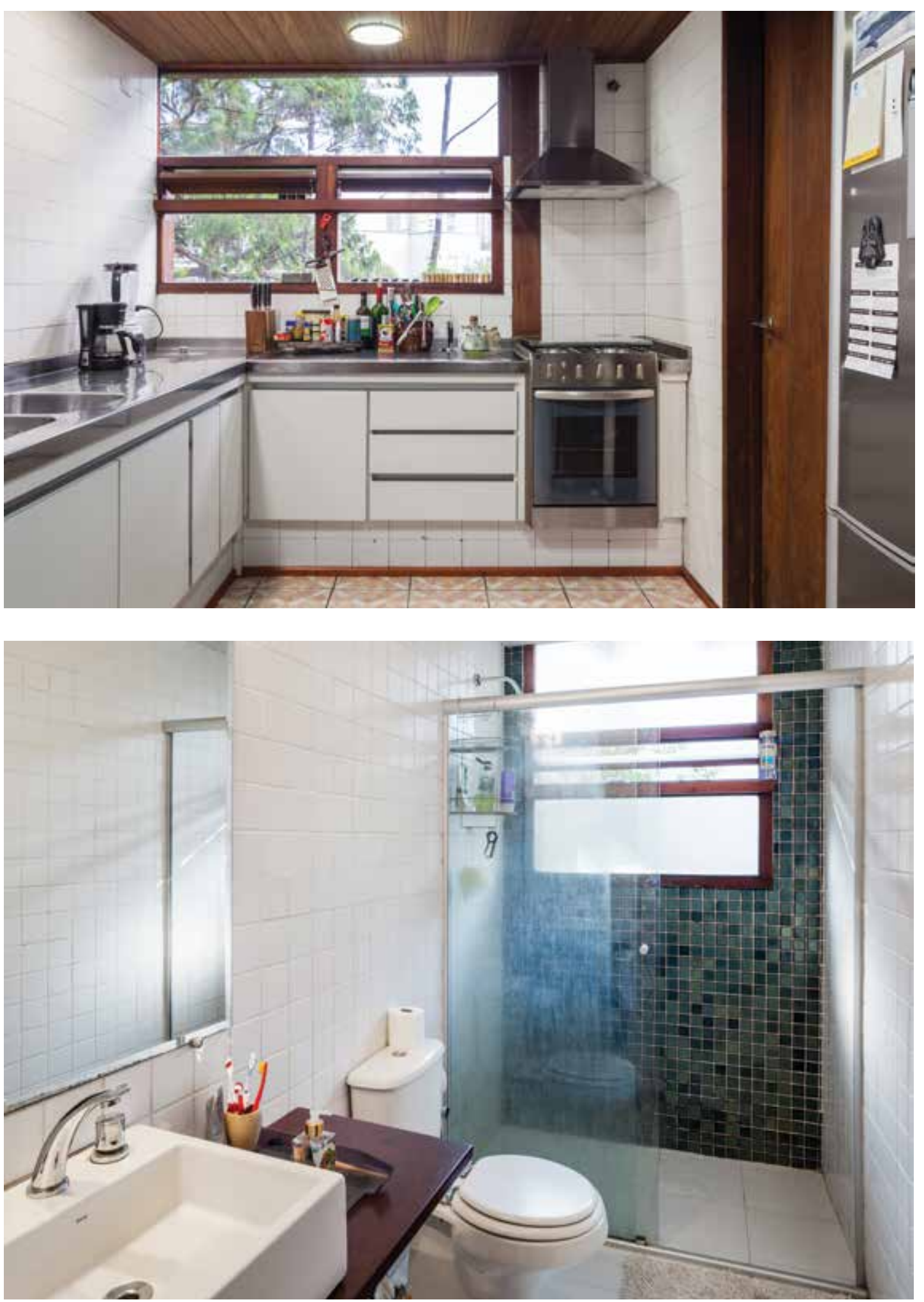
Figura 115, entrada quarto

casal. Fonte: acervo pessoal de

Amanda Carvalho, fotografia

de Rafaela Netto.

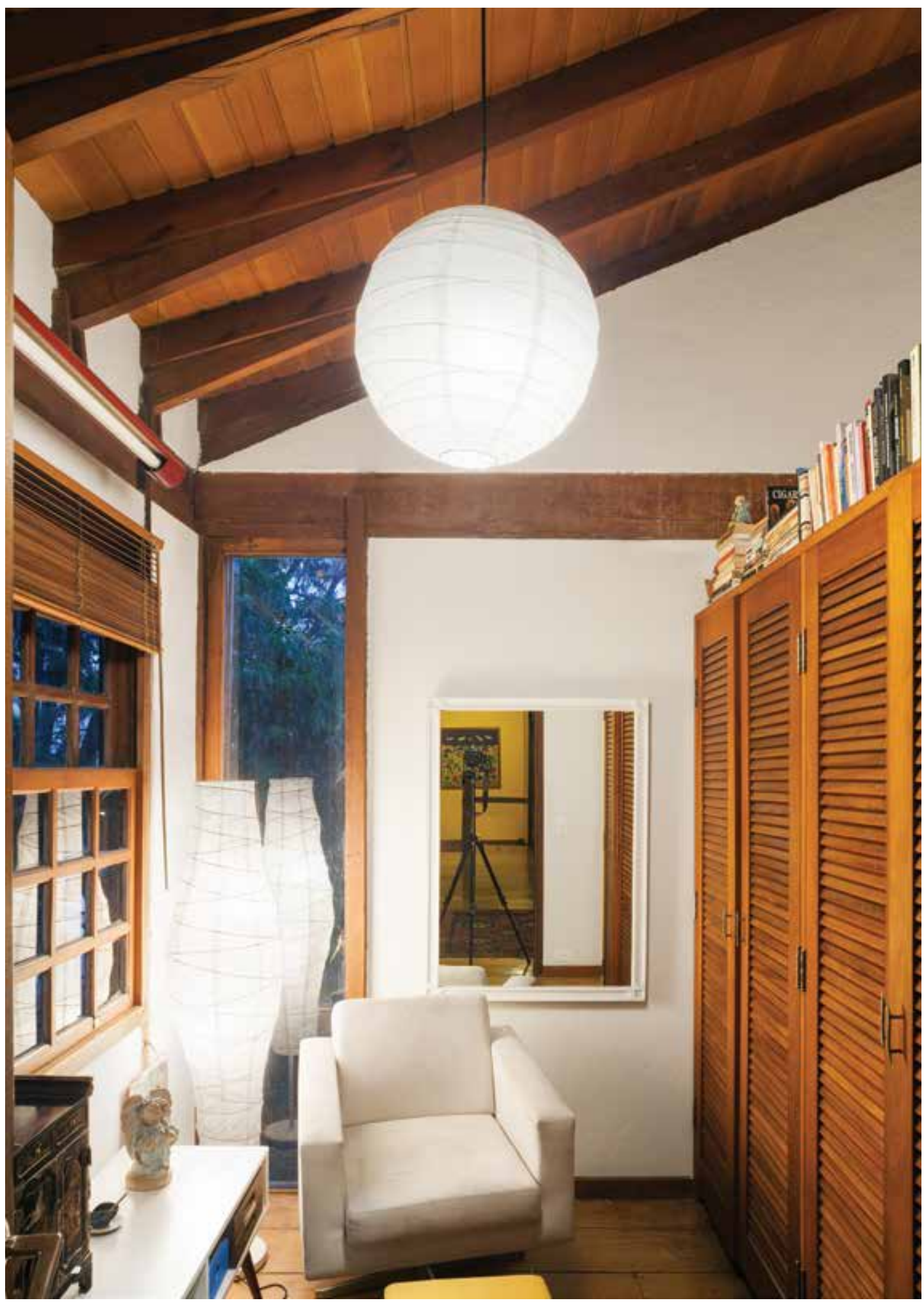




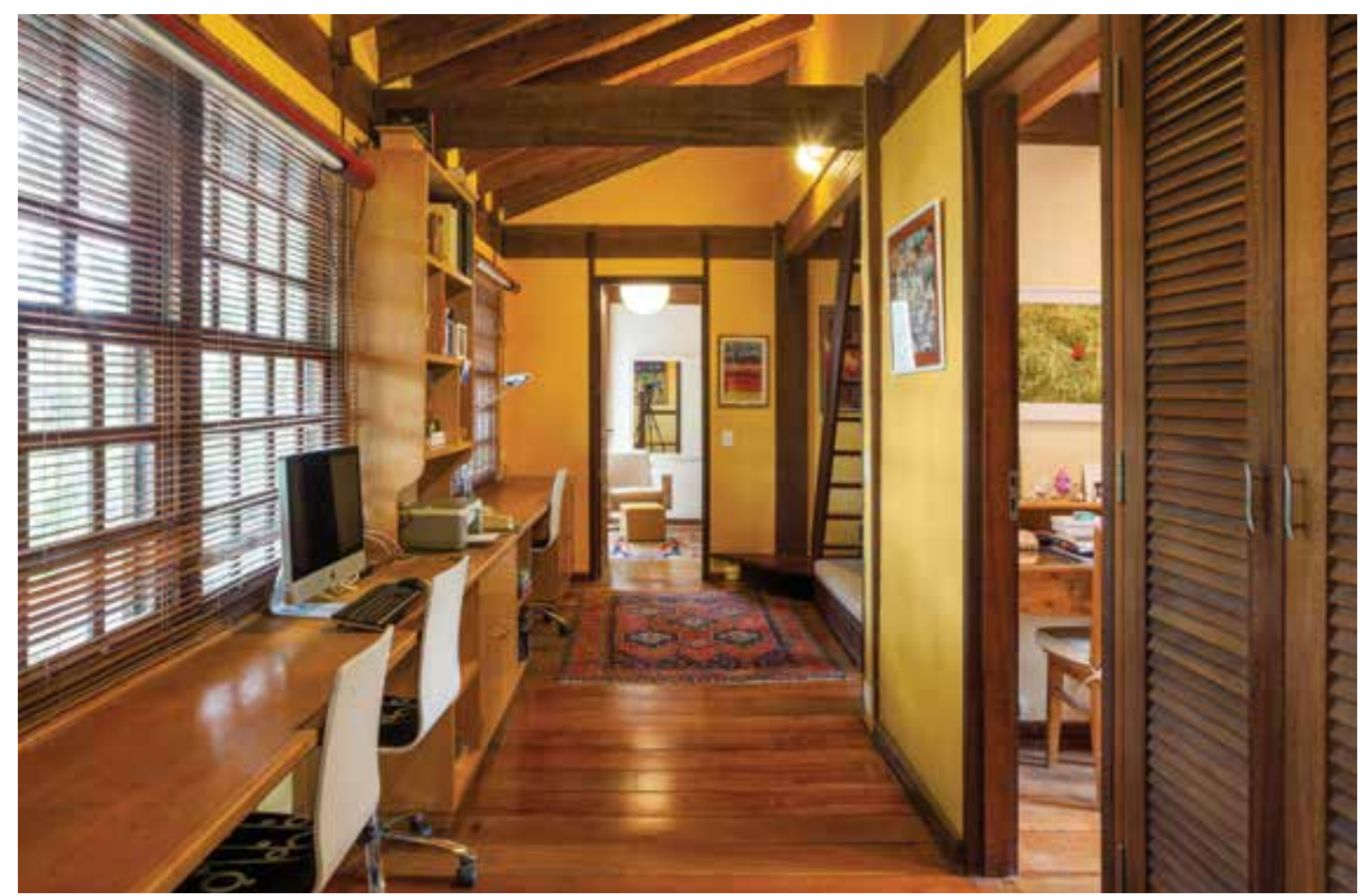

Figura 116. Corredor-escritório. Fonte: acervo pessoal de Amanda Carvalho, fotografia de Rafaela Netto.

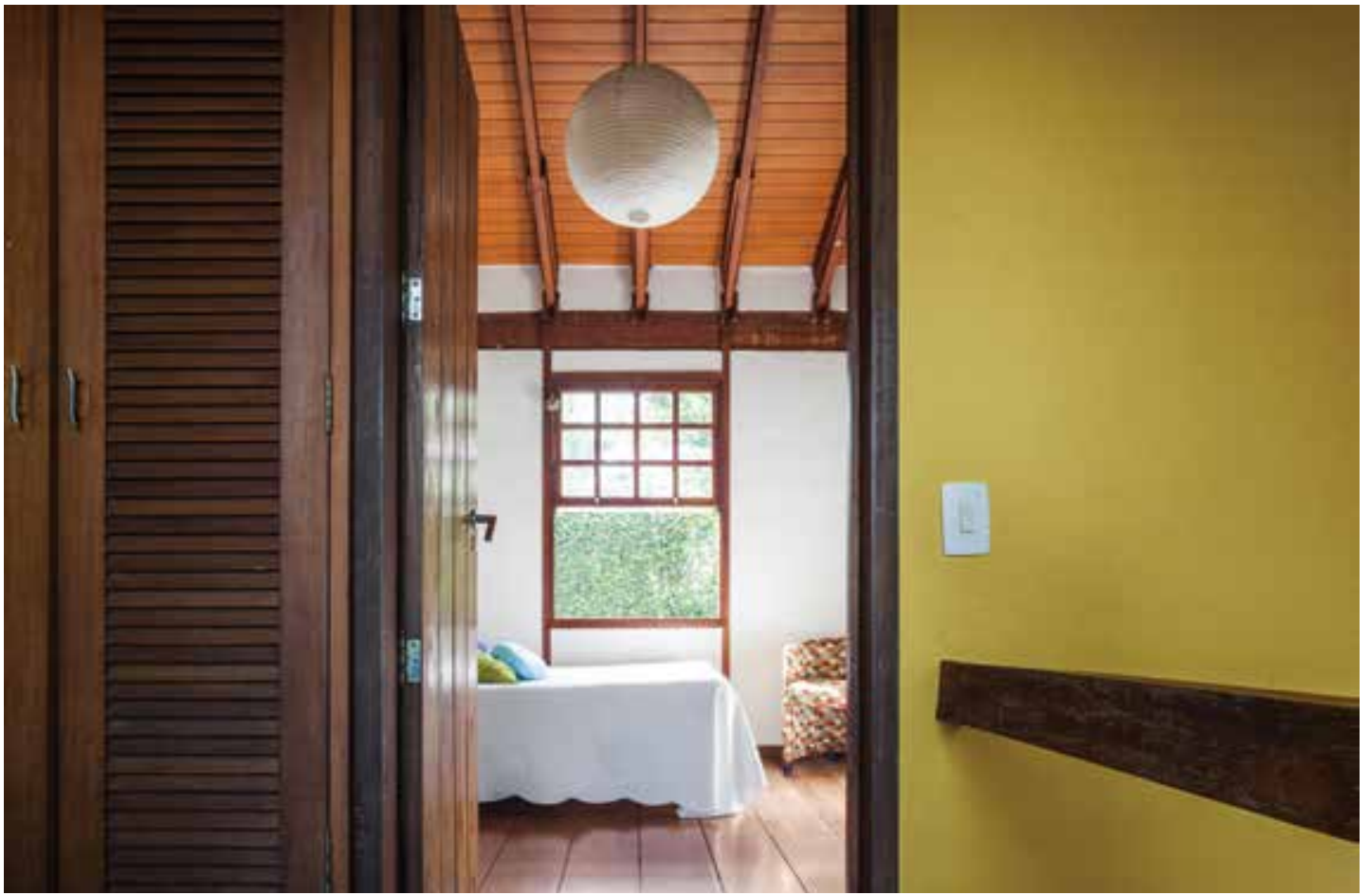

Figura 117. Quarto dos filhos. Fonte: acervo pessoal de Amanda Carvalho, fotografia de Rafaela Netto. 


\section{diálogos com técnicas construtivas tradicionais}

Ao observar a residência podemos notar semelhanças com a arquitetura tradicional do sul de Minas Gerais. Esta comparação é feita a partir do mestrado de Cícero Ferraz Cruz, Fazendas do Sul de Minas Gerais: Arquitetura Rural nos séculos XVIII e XIX.

Nesse trabalho, Cícero descreve o sistema construtivos de algumas fazendas do sul de Minas. Apoiar-nos-emos nesse trabalho para relacionar tais fazendas às residências construídas em Nova Viçosa por Zanine. Acredita-se que a relação é possível por Zanine sempre voltar seu olhar para o saber-fazer tradicional.

As casas das fazendas do sul de Minas, também, quando implantadas em meio à encosta, não fazem grandes cortes nem aterros; normalmente são construídos muros de pedras que fazem o ajuste necessário no terreno, elevando a casa do chão, afastando-a da umidade e criando um plano, no qual eleva-se a residência. Era comum aproveitarem essas paredes de pedra para construção de um porão.

Por serem técnicas de construção diferentes, elementos com a mesma função estrutural possuem nomes diferentes - os esteios das fazendas cumprem o papel dos pilares nas construções do Zanine e os baldrames das fazendas são as vigas inferiores das casas pré-elaboradas. Nas fazendas, o esteio não chegava até o chão, mas sim até o baldrame, que era apoiado no muro de pedras que fazia o ajuste necessário do terreno. Esse sistema é um avanço em relação ao anterior, em que o esteio chegava até o solo, o que tornava a estrutura hiper-estática, rompendo facilmente durante terremotos. No caso das casas pré-elaboradas, os pilares de madeira chegavam até a viga-inferior, sendo o ajuste com o terreno feito através de pilares de concreto.

Podemos estabelecer outras relações construtivas, a partir da leitura do texto de Cícero Cruz, entre as fazendas e as residências feitas por Zanine em Nova Viçosa, pois inicialmente assentavam os baldrames sobre os muros de pedra, que contornam todo o perímetro da casa. Quando os baldrames não tinham comprimento suficiente para atravessar a fachada da casa, uniam duas peças através da junção "raio de Júpiter".

Os barrotes das fazendas possuem mais do que o dobro da largura utilizada por Zanine. O espaçamento entre eles também era menor, reflexo da existência abundante de materia-prima na época:

Os barrotes são peças que têm seção média de 30 centímetros de largura por 25 centímetros de altura e vencem o vão entre vigas-mestras e baldrames. Este vão varia entre três a quatro metros $e$ é, historicamente, a largura mais comum dos lotes das cidades medievais do norte de Portugal, já que suas construçôes também utilizavam barrotes de madeira para vencer o vão entre as paredes portantes de pedra. A cada vão vencido por barrotes, temos um lanço. A distância entre barrotes é de 30 centímetros entre as peças e de 70 centimetros entre eixos. Este pequeno vão é facilmente vencido pelas tábuas do assoalho, que têm três centímetros de espessura e recobrem todo o barroteamento da casa. Em cima deste grande assoalho são levantadas as paredes internas, independentemente de onde estejam os barrotes ou as vigas-mestras. Muitas vezes, as paredes são 


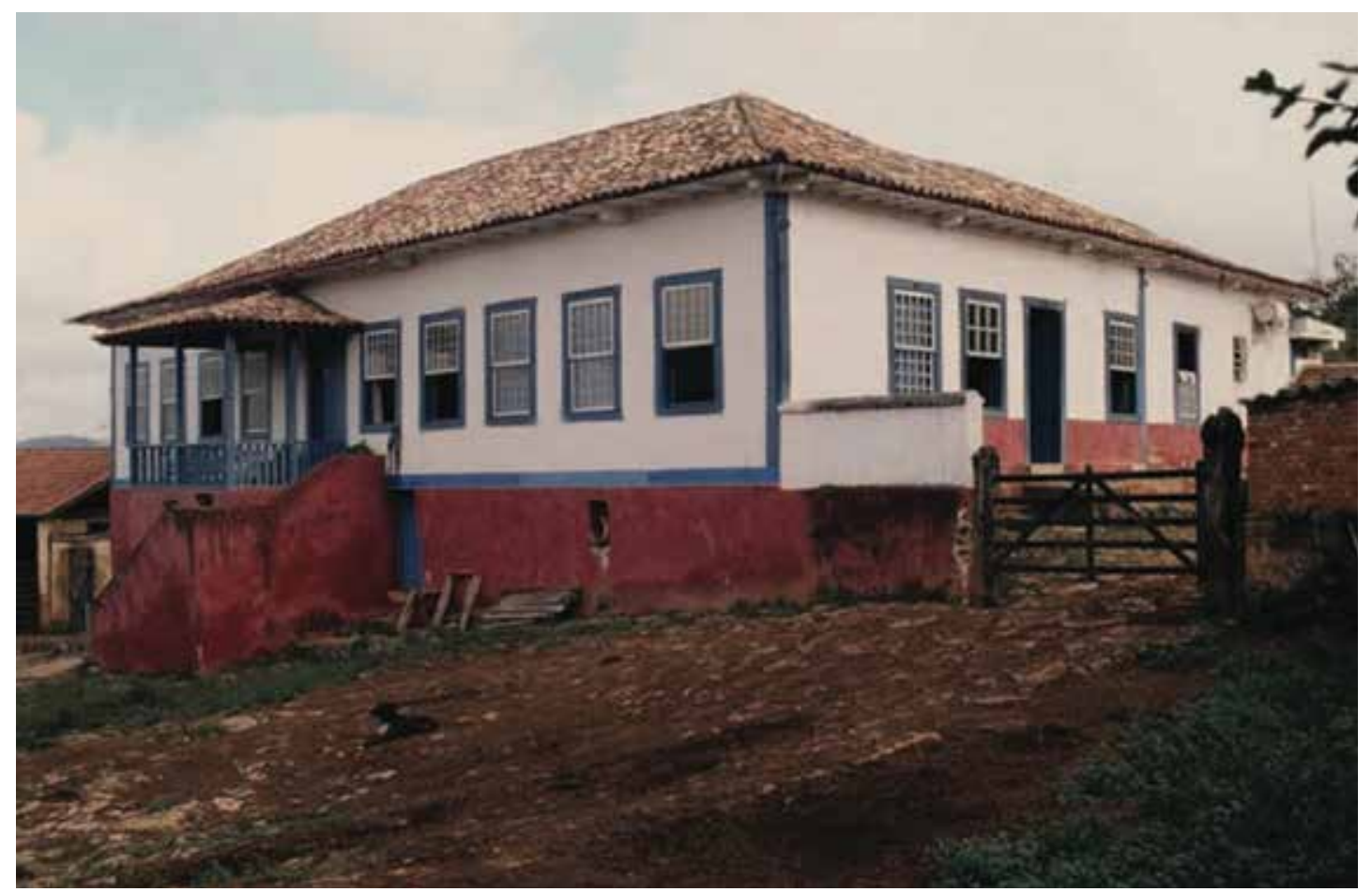

Figura 118. Fazenda Monte Alegre, em Cordislândia. Fonte: Cruq, 2008, p. 304.

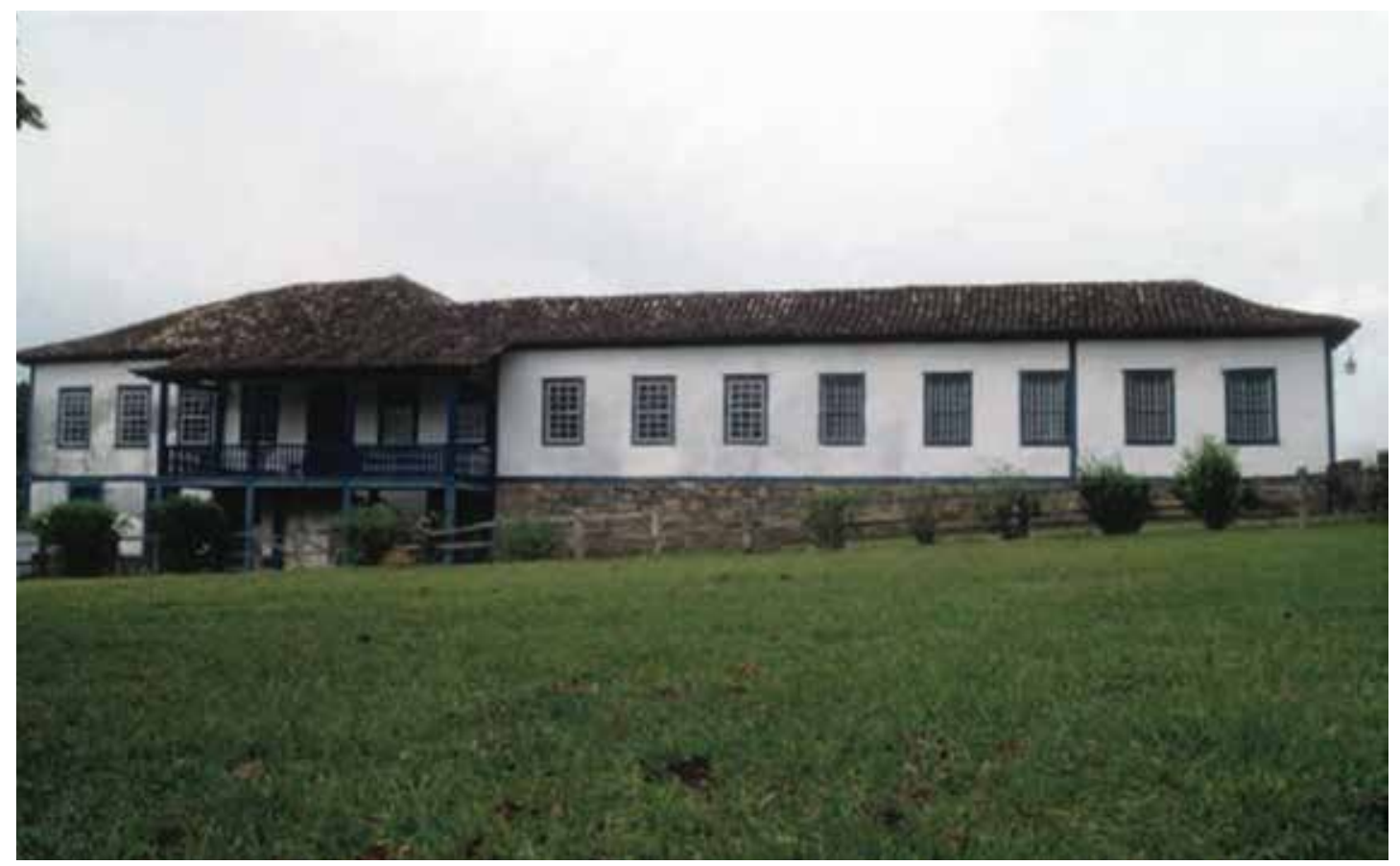

Figura 119. Faz̧enda Chapada, em Conceição dos Ouros. Presença de "cachorro", diminuindo inclinação do telhado, assim como de janelas guilhotinas, semelhantes às usadas por Zanine. Fonte: Cru₹, 2008, p. 292. 
apoiadas apenas em cima das tábuas, sem necessariamente coincidirem com a posição do barrote sob elas. Podemos dizer que é uma casa com a planta livre. (CRUZ, 2008, p.74)

Outras semelhanças são que a estrutura de madeira do telhado é independente da estrutura da casa, na qual o telhado simplesmente se apoia e que os beirais são sustentados por "cachorros", criando uma dupla inclinação do telhado, que é coberto por telhas de capa-e-canal.

Os peitoris e as vergas das portas e janelas, assim como nas casas pré-fabricadas em Nova Viçosa, não cumprem função estrutural no conjunto; apenas são unidos aos esteios. Uma diferença é que os vãos são fechados por paredes leves de pau a pique, sendo que na casa do Morumbi eles são fechados com tijolo de barro.

A forma de construção das portas é a mesma usada por Zanine: tábuas de madeira unidas através de encaixes macho e fêmea e unidas por travessas.

Os caixilhos são muito parecidos com os usados por Zanine, janelas do tipo "guilhotinha", sendo a folha superior fixa. Cada folha é composta por um quadriculado que suporta os vidros. A existência desse caixilho confere a essas casas uma semelhança plástica com a do Morumbi, aprofundada pelo uso principal da madeira na estrutura da residência. Além disso, as aberturas são bem marcadas e ritmadas na fachada

Para quem quiser se aprofundar nesse assunto recomendamos a leitura da referida dissertação de Cícero Ferraz Cruz.

Outro estilo que apresenta semelhanças com as casas desenvolvidas em Nova Viçosa é o enxaimel. Trazido principalmente pelos colonos alemães e suíços que vieram para o sul do Brasil e para a região serrana do Rio de Janeiro, essa técnica é usada desde a Idade Média, não sendo apenas germânica, mas usada em toda a Europa. Na França é chamada de colombage, na Alemanha, fachwerk.

A estrutura enxaimel possui algumas semelhanças com as casas feitas em Nova Viçosa, dentre elas, a principal é o fato de ser desmontável. A diferença com as casas pré-elaboradas está no uso das cantoneiras metálicas em L, parafusos e pregos na montagem, uma vez que as casas tradicionais utilizavam apenas encaixes de madeira, cunhas e pinos, provavelmente por serem os materiais mais fáceis de serem encontrados ou fabricados na época e por ser a forma como já construíam essas residências na Europa.

Outra semelhança está na forma de construção, desde como retiravam a costaneira da madeira e transformavam o tronco em uma tora de seção quadrada, conforme nos explica Weimer, estudioso da técnica enxaimel no sul do Brasil:

Enquanto estavam sendo construidas as fundações, o carpinteiro ou o falquejador escolbia as árvores que deveriam ser abatidas e determinava quando isso deveria acontecer, já que na época havia a crença da influência das fases da lua. Depois do abate e do corte dos galhos, o tronco era falquejado, serrado, ou passava pelos dois processos ao mesmo tempo. No primeiro caso, tomava-se um cordão que era tingido com fuligem umedecida em água, esticava-se o mesmo sobre o tronco para marcar uma linha reta que servia de base para o falquejamento que era feito com machado 


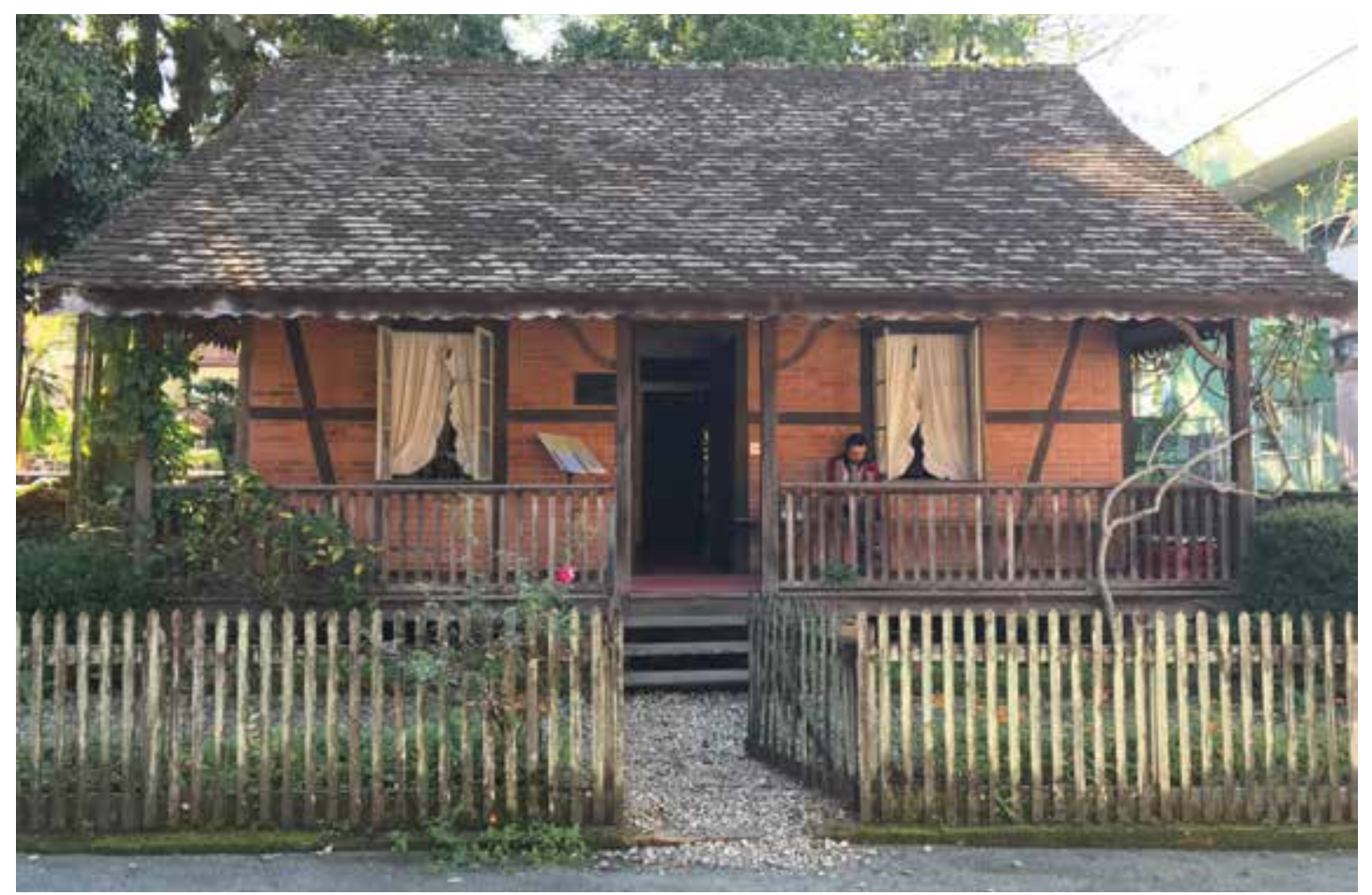

Figura 116. Museu do imigrante em Joinville, com estrutura enxaimel. Fonte: Amanda Carvalho.

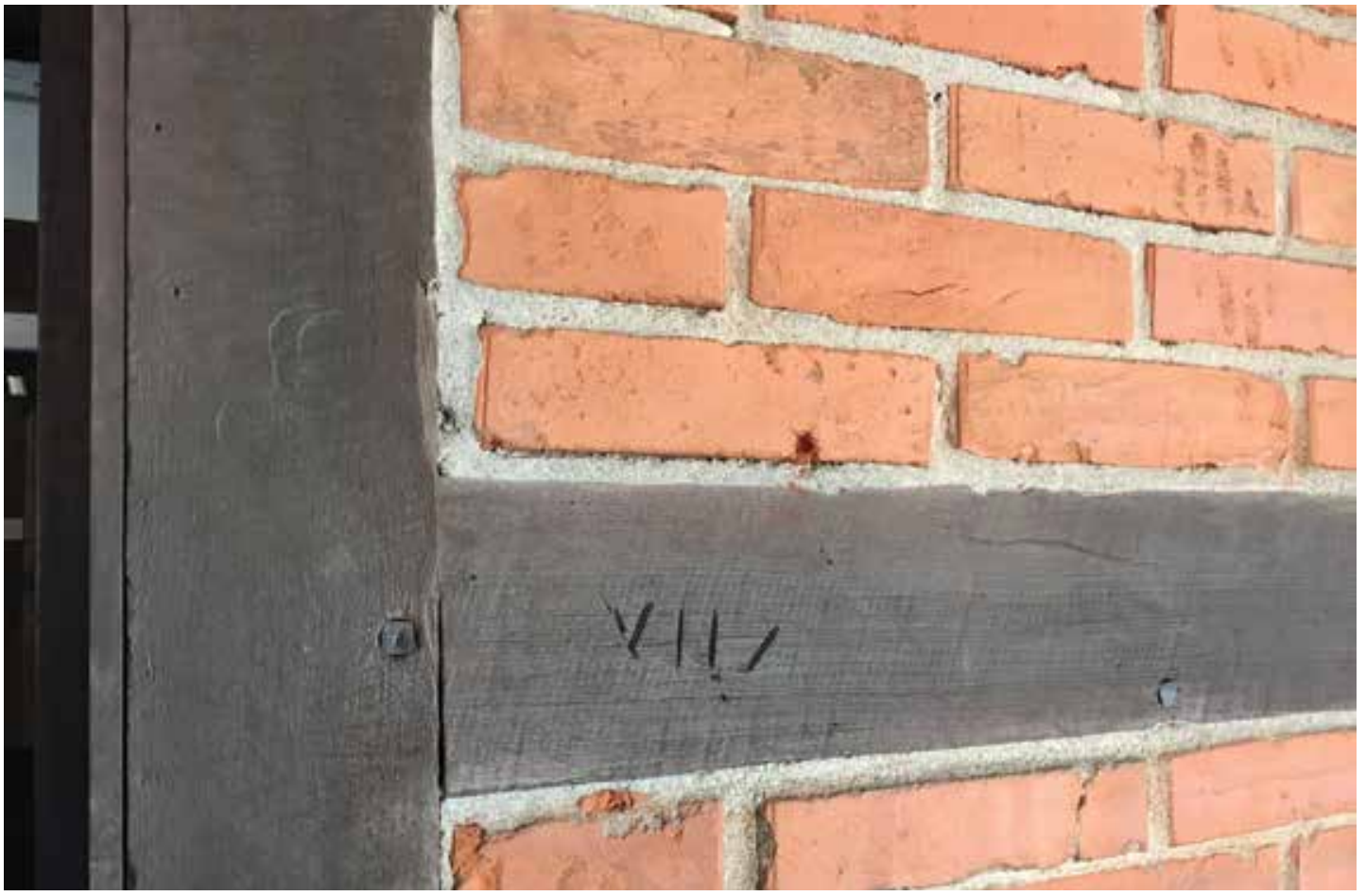

Figura 117. Detalhe de numeração das peças da estrutura, permitindo remontagem. Fonte: Amanda Carvalho. 
e consistia em desbastar uma fase do tronco até deixa-lo perfeitamente plano. Depois de repetir a mesma operação mais três vežes, o tronco era transformado em uma tora de seleção quadrada. (WEIMER, 1994, páginas 57 e 58)

Após esse processo, as casas em enxaimel também eram montadas em um local provisório, para depois serem remontadas como estrutura definitiva. Para facilitar a remontagem, cada parte da madeira utilizada na estrutura base desta construção recebia uma numeração entalhada, geralmente em algarismos romanos.

Uma curiosidade é que as residências alemãs em enxaimel não possuíam varanda, mas esta foi anexada no sul do Brasil, na frente e, às vezes, nos fundos da casa. Acredita-se que a mudança ocorreu principalmente como uma adaptação necessária ao clima do país, que possui chuvas com vento e é muito quente. Além da proteção, a varanda tinha como função o lazer, era nela que os amigos, os vizinhos e a família se encontravam para desfrutar das horas de descanso. E essa função se mantém nos dias de hoje. 



\section{considerações finais}





\section{considerações finais}

A vida inteira de Zanine foi permeada pelo saber-fazer. Figura inquieta e múltipla, Zanine trabalhou em diversas escalas, de pequenos arranjos florais e maquetes, passando por móveis, casas e até cidades.

Depois de trabalhar com os principais arquitetos modernos e de fazer a fábrica de móveis Z, Zanine voltou para o sul da Bahia no final da década de 1960, com aproximadamente 50 anos de idade, e começou a fazer móveis rústicos e pesados, aparentemente contrariando todo o seu trabalho de juventude e toda a lógica do desenvolvimento tecnológico. Essa mudança na sua forma de trabalhar gerou uma inquietação: qual é o significado do trabalho de Nova Viçosa na obra de Zanine? Por que voltar ao trabalho artesanal e ao uso da madeira bruta?

Na busca da resposta a essa questão, o texto de Santos (1993) nos tráz uma luz:

Para além dos questionamentos colocados inicialmente, é interessante notar que a obra de Zanine comecou, ao ter contato com os projetos e discussões dos principais arquitetos modernos, com a Fábrica de Móveis Z. Uma proposta de mobiliário popular e moderno, com a intenção de suprir a necessidade de móveis num momento de grande crescimento das cidades. Mas que o seu trabalho maduro retorna para a sua vida no interior de Belmonte, quando criança observava o fazer artesanal dos habitantes. Zanine, ao invés de continuar a busca pela industrialização, resgatou o significado bistórico da forma de produção artesanal e "projetou-os para além de seu círculo original, utilizando-o com eficiência na produção de outros bens”. (SANTOS, 1993, p. 175)

Ele revisitou a sua infância, as suas raízes, mas agora maduro. Em Nova Viçosa, reencontrou conhecimentos tradicionais, que passavam de pai para filho e eram experimentados e reformulados durante gerações, saberes que conhecia bem e admirava. Zanine entendia que a população que depende da natureza para a sobrevivência sabe como usá-la sem danificá-la, e, para ele a natureza é o ambiente que fornece todos os materiais necessários à vida humana, sendo assim, deve ser preservada e valorizada.

Zanine voltou para a Bahia com a ideia de fazer um projeto para a cidade, repensar como ela poderia ser. Para quem viu a capital de um país sendo feita em poucos anos, a construção de uma pequena cidade no interior da Bahia não era um 
Figura 118. Benedito fazendo

maquetes de memória em sua

carpintaria. Fonte: Amanda

Carvalho, fotografia de

Laressa Matos.

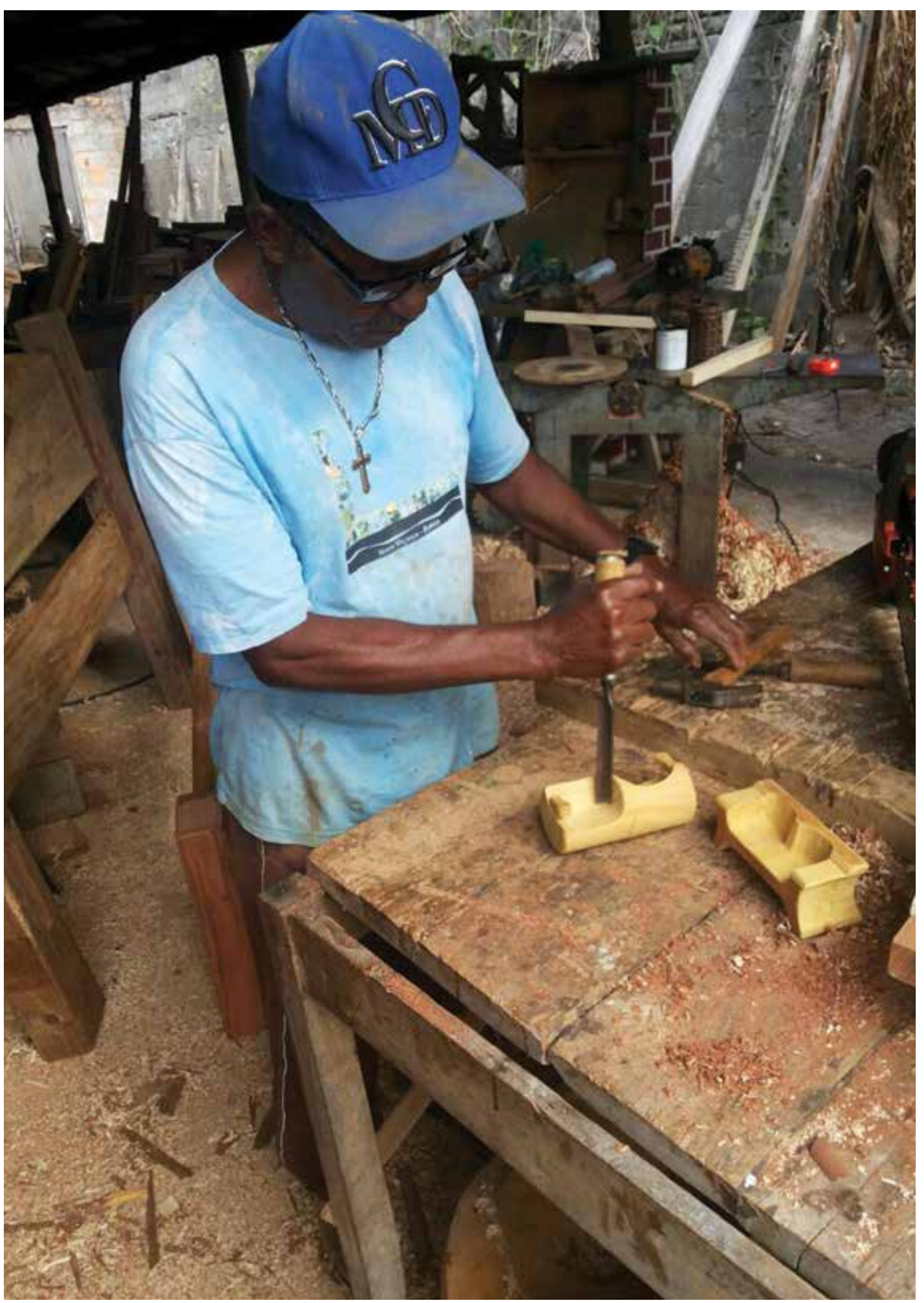


sonho, mas algo possível. Zanine conhecia e admirava os potenciais adormecidos de sua cidade. Acredito que imaginou que poderia fazê-los brilhar, aproveitando todas as qualidades do lugar, a natureza, as pessoas e os seus saberes-tradicionais, qualidades que poderiam ser perdidas se não fossem valorizadas.

Por isso, essa fase de Zanine extrapolou o trabalho que traz o sustento, e trouxe o sonho de criar uma cidade, uma reserva ecológica, uma forma de viver em que homem e natureza convivessem equilibradamente, harmonicamente.

A troca de conhecimentos sempre esteve presente na obra de Zanine. Como ele mesmo nunca frequentou uma escola e começou aprendendo com as pessoas de Belmonte, sabia que o aprendizado se dava pela troca, pela convivência, antes mesmo do que em escolas. E podemos afirmar que o período em que esteve em Nova Viçosa foi de troca: aprendeu com os construtores de canoas sobre como o uso do enxó vinculado ao movimento do braço cria formas sinuosas, muito bonitas, e ensinou pessoas simples a construir móveis e casas.

O resultado é que, ao visitar a cidade de Nova Viçosa, até hoje encontramos habilidosos carpinteiros que trabalharam com o Zanine e que aprenderam com ele, como é o caso de Seu Benedito (f.118), que, quando questionado se havia aprendido algo com Zanine, respondeu: "É um orgulho que eu tenho, porque aprendi, não sabia. Eu agradeço muito tudo o que ele me ensinou, e os meus amigos que me ajudaram, que me ensinaram" (BENEDITO, depoimento de 17/08/2017).

Também há jovens que, inspirados nos desenhos de Zanine, criaram sua própria marcenaria (f.119 e f.120), muitas vezes tendo como mestres os carpinteiros que trabalharam com Zanine e utilizando as mesmas técnicas de construção empregadas pelos mesmos.

Valorizar o saber da população é fundamental para Zanine, o que o fez planejar uma escola para que os habitantes pudessem desenvolver suas habilidades construtivas, incentivando a sabedoria popular e retomando a dignidade profissional desses artesãos, criando um ambiente de experimentação que poderia fazer com que eles fossem capazes de estabelecer relações entre os seus conhecimentos, usando a fantasia, a invenção e a criatividade nas suas produções. Como matéria-prima utilizariam materiais encontrados na região: a palha, a concha, a madeira. Ele acreditava que usando os materiais naturais, aprenderíamos a valorizá-los, acabando com a cultura irracional do desperdício. Por isso seus móveis eram feitos a partir de sobras de madeira sem uso comercial, madeiras que eram as sobras da Elecunha.

Não se sabe até quando esses jovens continuarão desenvolvendo móveis e usando as técnicas tradicionais de construção. A dificuldade em encontrar grandes troncos de madeira impossibilita que móveis como os feitos em 1970 continuem a ser fabricados, o que coloca a necessidade de adaptação da técnica para a matéria-prima encontrada. $\mathrm{E}$ aí está um dos problemas do artesanato atualmente e a sua relação com o mercado. Ao chegar em uma forma aceita pelo mercado, há a tendência de estagnar a experimentação, repetindo a forma final e construtiva do objeto. Uma vez que os materiais já não 


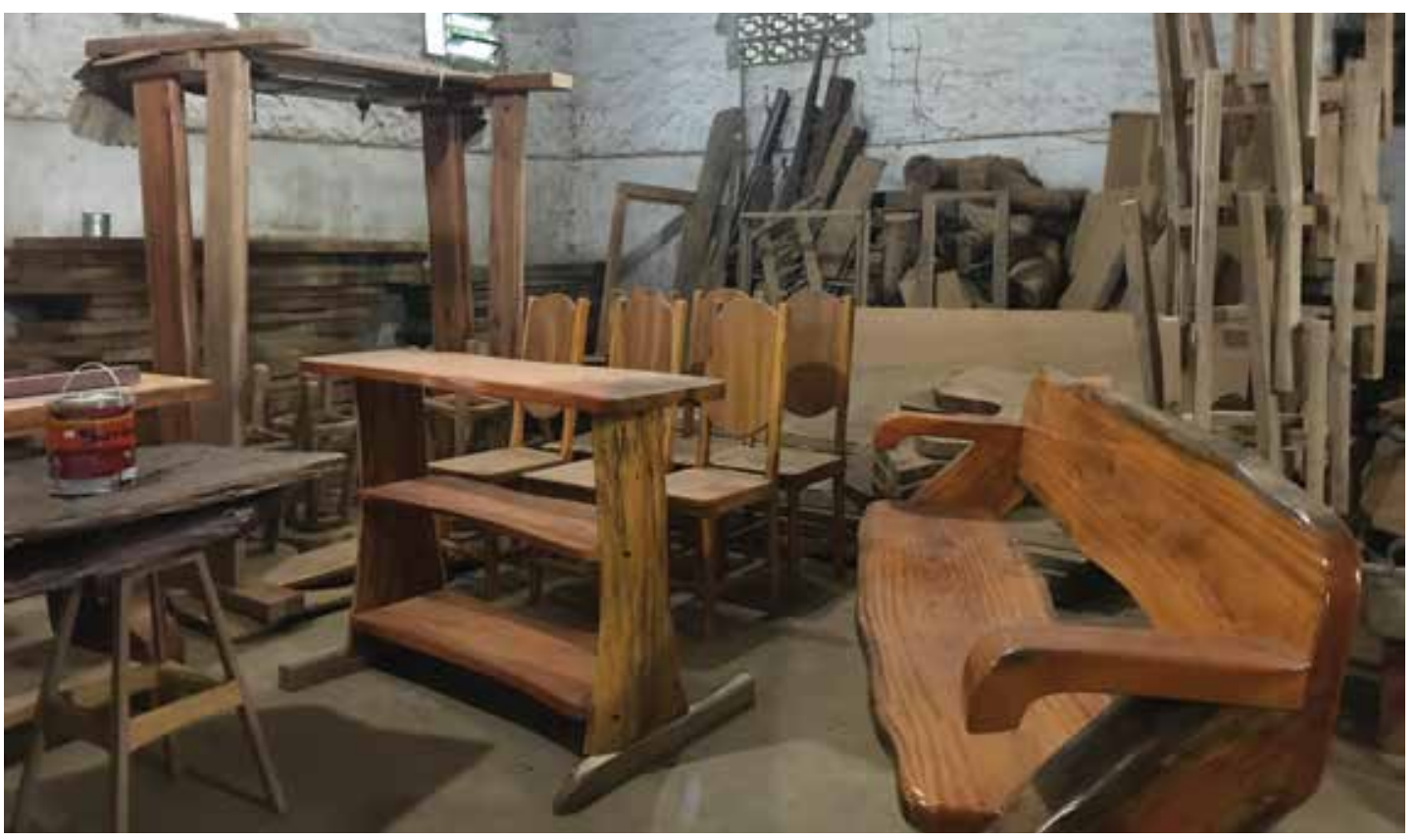

Figura 119. Marcenaria de um jovem carpinteiro. Fonte: Amanda Carvalho.

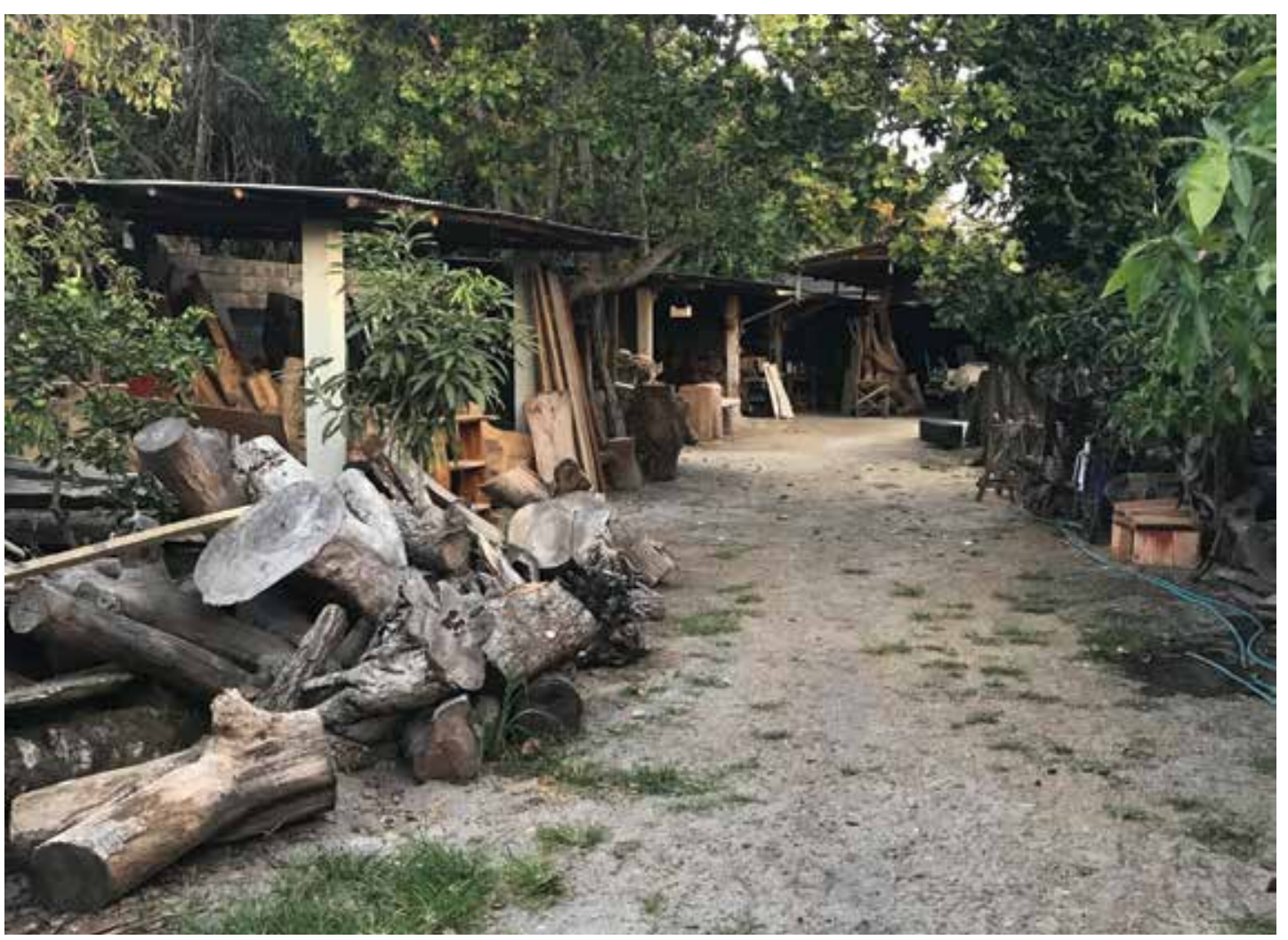

Figura 120. Marcenaria de um jovem carpinteiro. Fonte: Amanda Carvalho. 
são encontrados, na falta de incentivos para a livre experimentação há uma grande possibilidade de que estes artesãos não reconheçam mais a importância do seu trabalho e do seu conhecimento, perdendo-se essas técnicas de construção.

Provavelmente a escola idealizada por Zanine modificaria a situação atual da técnica construtiva e a sua relação com a matéria-prima do local, mas a sua existência era condicionada a um apoio por parte da prefeitura, o que não aconteceu.

Também há grande preocupação da pesquisadora acerca da preservação das poucas residências projetadas por Zanine em Nova Viçosa. Muitas vezes a falta de manutenção dessas casas pode levar ao desaparecimento das mesmas.

Espera-se que este trabalho possa contribuir para a ampliação do conhecimento da obra de Zanine Caldas em Nova Viçosa, valorizando o saber-fazer dos habitantes, incentivando a preservação da natureza da região, assim como das poucas obras de Zanine que restam na cidade. Acredita-se que alongando a cultura e o conhecimento de arquitetos, designers, governantes e sonhadores, como o próprio Zanine, possa-se aumentar a imaginação e a intervenção na cidade existente. 



\section{bibliografia}

\section{Livros e periódicos}

AMARAL, Aracy A. (org.) Projeto Construtivo Brasileiro na Arte (1950-1962), Rio de Janeiro - São Paulo: MEC- FUNARTE, 1977.

ARC DESIGN. São Paulo, n.9, 1999, p.48-53.

BARDI, Lina Bo. Tempos de Grossura: O Design no Impasse. São Paulo: Instituto Lina Bo e P. M. Bardi, 1994.

BARTHOLOMEU, Clara. José Zanine Caldas e sua contribuição na Arquitetura e Design. Relatório de iniciação científica, FAUUSP, São Paulo, 2016, com apoio da FAPESP.

BENJAMIN, Walter. Reflexões sobre a criança, o Brinquedo e a Educação. São Paulo: Editora 34, 2011.

Casa \& Jardim (volume 3): p. 9, 1953.

CANDIDO. Antonio. A Revolução de 1930 e a Cultura. Revista Novos Estudos Cebrap, São Paulo, n. 4, v. 2,4, abril 1984, p. 27-33.

CHAIM, Giselle Marie Cormier. O mestre, a madeira e a habitação | Residências de Zanine Caldas em Brasília 1963-1985. Dissertação de mestrado, UnB, 2017.

DOAT, Patrice; SHNEEGANS, Guy. Guyane: artisanat, mobilier, habitat. Grenoble: CRATerre-eag, 1993.

COSTA, Lúcio. Lúcio Costa. Registro de uma vivência. São Paulo: Empresa das Artes, 1995. 
. Notas sobre a evolução do mobiliário luso-brasileiro. Revista do SPHAN, Rio de Janeiro, n.3, 1939, p. 149-63.

CRUZ, Cicero F. Fazendas do sul de Minas Gerais: Arquitetura Rural nos séculos XVIII e XIX. 2008. 357f. Dissertação (Mestrado em Arquitetura e Urbanismo) - Escola de Engenharia de São Carlos da USP, São Carlos.

FACO, Luciane Costa. O surgimento do conceito de preservação ambiental na metodologia de projeto de produto em design: Pioneirismo de Zanine Caldas no Brasil. In BRAGA, Marcos da Costa; e MOREIRA, Ricardo (orgs.). Historias do Design no Brasil. São Paulo: Annablume, 2012. p. 75-90.

FRAMPTON, Kenneth. História Crítica da Arquitetura Moderna. São Paulo: Martins Fontes, 1997.

FREIRE, Paulo. Pedagogia da Autonomia: saberes necessários à prática educativa. Rio de Janeiro: Paz e Terra, 2016.

Pedagogia do Oprimido. Rio de Janeiro, Paz e Terra, 2014.

FUNDAÇÃO DAM. Taipa em painéis modulados. MEC - CEDATE - Centro de desenvolvimento de Apoio Técnico à Educação. Brasília, editora da Universidade Católica de Goiás, 1988.

GAMA, Ruy. Engenho e tecnologia. São Paulo: Livraria duas cidades, 1983.

GERHARDT, Tatiana Engel, SILVEIRA, Denise Tolfo (Orgs). Métodos de pesquisa. Porto Alegre: Editora da UFRGS, 2009

GIL, A. C. Como elaborar projetos de pesquisa. 3 ed. São Paulo: Atlas, 1991.

HAGUETTE, Teresa Maria Frota. Metodologias qualitativas na Sociologia. $5^{\text {a }}$ edição. Petrópolis: Vozes, 1997.

KATINSKY, Júlio Roberto, O concretismo e o desenho industrial. In: AMARAL, Aracy A. (org.), Projeto Construtivo Brasileiro na Arte (1950-1962), Rio de Janeiro - São Paulo: MEC- FUNARTE, 1977.

Depoimento de Júlio Katinsky. In: Arquitetura Brasileira após Brasília: Depoimentos. Rio de Janeiro, IAB, 1978. P. 37-67. 
Le CORBUSIER, A arquitetuta e as Belas artes. In: Revista do Patrimônio Histórico e Artístico Nacional n. 19, 1984.

LEON, Ethel. Zanine: o mago da madeira. In: Design \& Interiores. São Paulo: Pro Editores, (14), 1989.

MAGALHÃES, Aloísio. O que o desenho industrial pode fazer pelo país? Arcos, Rio de Janeiro, V. 01, p. 08-13, out. 1998.

MANHÃES, Fernanda Castro; MEDEIROS, Carlos Henrique; KAUARK, Fabiana da Silva. Metodologia da pesquisa: um guia prático. Itabuna/ Bahia, 2010. Disponível em: < http://www.pgcl.uenf.br/2013/download/livrodemetodologiadapesquisa2010. pdf $>$. Acesso em: 10 nov. 2014.

MELO, Alexandre Penedo Barbosa de. Moveis artísticos Z (1948-1961): o moderno autodidata e seus ressortes sinuosos. Dissertação de mestrado, departamento de Arquitetura e Urbanismo da Escola de Engenharia de São Carlos, 2001.

. Arquitetura moderna em São José dos Campos. Editora: [O Autor], 1997, São José dos Campos.

MINISTÉRIO DO INTERIOR. Dez Alternativas Tecnológicas para Habitação. Brasília, editora MINTER/ PNUD, 1989.

MORAES, Roque. Análise de conteúdo. Revista Educação, Porto Alegre, v. 22, n. 37, p. 7-32, 1999.

MUNARI, Bruno. Fantasia. Lisboa: Edições 70, 2007.

NEVES, José Luís. Pesquisa qualitativa: características, usos e possibilidades. Caderno de Pesquisas em Administração, São Paulo, v. 1, n. 3, 1996. Disponível em: $<$ http://www.ead.fea.usp.br/cad-pesq/arquivos/C03-art06.pdf>. Acesso em: 21 jul. 2014.

Nova Viçosa: no sul da Bahia, Zanine e Krajcberg criam um paraíso para a arte e o lazer. O Globo, seção turismo, 6 de março de 1973.

Ornamentação para o carnaval. Folha da Manhã, 27 Fev 1957 Cad. Assuntos Gerais, p.1. PEDROSA, Mário. A arquitetura moderna no Brasil. In: XAVIER, Alberto (org.). 
Depoimento de uma Geração, Cosac Naify, São Paulo, 2003, pp. 98-105.

Residência no Morumbi. Acrópole, São Paulo, Fev 1956, No 209, p. 176 ss;

SANTOS, Maria Cecília Loschiavo dos. Tradição e Modernidade no Móvel Brasileiro. Tese Doutorado FFLCH USP, São Paulo, 1993.

Móvel Moderno no Brasil. São Paulo: Olhares, 2015.

Brasil Faz Design, design e madeiras no Brasil .São Paulo: Museu da Casa Brasileira, 2000 [folheto da exposição].

SANTOS, Maria Cecília Loschiavo dos; SAKURAI, Tatiana. Móvel Moderno Brasileiro. São Paulo: Olhares, 2017.

SILVA, Suely Ferreira. Zanine sentir e fazer. Rio de Janeiro: Agir, 1988.

SEGAWA, Hugo. Depoimento. Ver Zanine. Rio de Janeiro: Centro Cultural Banco do Brasil, 2003 [folheto da exposição, 28 abril-29 julho].

VIVACQUA Conrado. Para Zanine que a fez: Residência e Ateliê de Sérgio Camargo em Jacarepaguá. São Paulo: Trabalho final de graduação apresentado na faculdade de arquitetura e urbanismo da USP, 2013.

WEIMAR, Günter. Arquitetura Enxaimel em Santa Catarina. São Paulo: Editora L\&PM, 1994.

Arquitetura da imigração Alemã: Um estudo sobre a adaptação da arquitetura centro-européia ao meio rural do Rio Grande do Sul. Porto Alegre: Editora da Universidade, 1983.

XAVIER, Alberto (org.) Depoimento de uma geração. Arquitetura Moderna Brasileira. São Paulo: Cosac Naify, 2003.

Yvone Jean. A arte original de Zanine. Folha da Manhã, 24 de jun. 1956, p. 65.

\section{Filmes}

HORTA, André. ZANINE: Ser do Arquitetar. Rio de Janeiro: distribuidora desconhecida, 2015. I DVD (80min), documentário color. 


\section{Processos}

Processo USP n ${ }^{\circ}$ 50.1.04081.01.5. José Zanine Caldas - Sobre contrato do interessado para exercer as funções de maquetista na FAU.

Processo USP no 51.1.14846.01.5. José Zanine Caldas - Rescisão do contrato do interessado.

\section{Entrevistas}

Ricardo Caruana, São Paulo, SP, 29 de fevereiro de 2016.

Ivan do Valle, São Carlos, SP, 09 de junho de 2016.

Júlio Katinsky, São Paulo, SP, 09 de junho de 2016.

Ivan do Valle e Elayne Farias, Brasília, DF, 27 de setembro de 2016.

Ricardo Caruana, São Paulo, SP, 25 de novembro de 2016.

Helio Olga, São Paulo, SP, 02 de fevereiro de 2017.

Reduzino da Silva, Rio de Janeiro, RJ, 04 de maio de 2017.

Benedito Batista, Nova Viçosa, BA, 17 de agosto de 2017.

Peu, Nova Viçosa, BA, 17 de agosto de 2017.

Reinaldo da Silva, Nova Viçosa, BA, 17 de agosto de 2017.

Teodório Cardoso, Nova Viçosa, BA, 17 de agosto de 2017.

Carlos Fanticelli, Nova Viçosa, BA, 19 de agosto de 2017.

Maria Aparecida Fanticelli (Cida), Nova Viçosa, BA, 19 de agosto de 2017.

Tancredo Barros, Nova Viçosa, BA, 19 de agosto de 2017.

Teodório entrevista Benedito, Nova Viçosa, BA, 12 de setembro de 2017.

Claudia Orthof, Teresópolis, RJ, 08 de novembro de 2017. 
Casal Maria Fernanda Magalhães e Joaquim Jubé, São Paulo, SP, 02 de novembro de 2017.

Cydno Silveira, Rio de Janeiro, RJ, 09 de novembro de 2017.

Déa de Zanine (Cuca), Rio de Janeiro, RJ, 09 de novembro de 2017.

Ustane Lopes, Niteroi, RJ, 09 de novembro de 2017. 

